UNIVERSIDADE DE SÃO PAULO

INSTITUTO DE FÍSICA

INSTITUTO DE QUÍMICA

INSTITUTO DE BIOCIÊNCIAS

FACULDADE DE EDUCAÇÃO

GUILHERME VENTURA BONDEZAN

Perspectivas de cidadania articuladas com o conhecimento escolar de Física

Orientadora: Prof. ${ }^{a}$ Dr. ${ }^{a}$ Maria Regina D. Kawamura

São Paulo

2019 


\title{
Perspectivas de cidadania articuladas com o conhecimento escolar de Física
}

\author{
Versão Corrigida
}

Dissertação apresentada ao Programa de Pós-Graduação Interunidades em Ensino de Ciências da USP, nível mestrado, como requisito para o título de mestre em Ensino de Ciências. Área de concentração: Ensino de Física.

Orientadora: Prof ${ }^{\mathrm{a}}$. Dra ${ }^{\mathrm{a}}$ Maria Regina Kawamura.

SÃO PAULO 


\section{FICHA CATALOGRÁFICA}

\section{Preparada pelo Serviço de Biblioteca e Informação}

\section{do Instituto de Física da Universidade de São Paulo}

Bondezan, Guilherme Ventura

Perspectivas de cidadania articuladas com o conhecimento escolar de Física - São Paulo, 2019.

Dissertação (Mestrado) - Universidade de São Paulo. Faculdade de Educação, Instituto de Física, Instituto de Química e Instituto de Biociências.

Orientadora: Prof ${ }^{a}$. Dr ${ }^{\mathrm{a}}$. Maria Regina Dubeux Kawamura.

Área de Concentração: Física

Unitermos: 1. Física - Estudo e ensino; 2. Educação para a cidadania; 3. Ensino.

USP/IF/SBI-081/2019 


\section{Agradecimentos}

Gostaria de começar lembrando de um amigo que infelizmente não mais está entre nós. Dirceu Lucas Pinheiro Rosa partiu no início de 2016, mas antes disso foi calouro junto comigo, em 2012 e, entre estágios e almoços no bandejão, foram muitas as conversas, discussões, e aventuras. Eu tinha muitas divergências com ele e seria muito interessante, após minhas mudanças de leitura de mundo e aventuras pela filosofia, incluindo no mundo de Foucault, seu ídolo, complexificar as discussões de início de graduação.

Gostaria de agradecer aos amigos e amigas desde o início da graduação, Alexandre dos Santos, Deyvid Santos, Diego Mattos, Fábio Martins, Leandro Ferreira, Marcus Vinícius, Marcos Lima Leite, Rafael Mancini, Rodrigo Tonom e muitos outros, aos meus bixos e bixetes, como André Fabrete, Aureliano Pereira, Camila Deodato, Leonardo Bertelli, Oswaldo Amorim, entre outros e aos amigos e amigas da pós-graduação, como André Noronha, Danilo Cardoso, Fernando Augusto, Flávia Polati, Rachel Deboni Papa, Raquel Melo, Sofia Guilhem, Yuri Machado, entre outros, por todas as conversas, risadas e aprendizados.

Ao pessoal do Encontro da Licenciatura, desde seus idealizadores, como Daniele Vieira, Danilo da Silva Júnior e Hevila Moura, até as pessoas que foram se unindo e tornando o grupo mais forte. São pessoas que, tais como os (as) idealizadores (as), são profundamente engajadas em educação. São elas Beatriz Novaes, Carlos Alberto Chaves, Flávio Lídio, Ihanna Silveira dos Santos, Márcia Almeida, Michelle Sena, Thaís Alexandre e Vivian Costa.

Gostaria de agradecer especialmente ao Lucas Gualberto, pelos inúmeros debates, incluindo política, economia, teoria da atividade, PISA, CTS e Alfabetização Científica, modelos de aprendizagem e compartilhamento de angústias, assim como ao Rodolpho Lima Leite, por todo o suporte, carinho e aprendizado.

Agradeço também ao Walter Mendes Leopoldo, não apenas pela prestatividade incomparável, mas também pela paciência, compreensão, suporte e as infinitas discussões sobre política e atualidades, sempre acompanhadas de bom humor, piadas e inquietações.

Agradeço, também, profundamente à Érica de Oliveira, Fernanda Souza dos Santos e Fábio da Silva Cruz, por todo o apoio, compreensão, risadas, diversões, discussões e aprendizado. Por me dar suporte e forças, por compartilhar angústias, inquietações e sonhos.

Fica aqui meu agradecimento, também, a todas as professoras e a todos os professores que tive, em todos os níveis de escolarização. Elas e eles tiveram um papel central em meu desenvolvimento intelectual e em proporcionar um acesso ao conhecimento de maneiras únicas. Em especial, agradeço aos professores do Corredor do Ensino do IFUSP, Valéria Silva 
Dias, Ivã Gurgel, Cristiano Matos e Cristina Leite, assim como a Luis Carlos de Menezes, Nora Lia Maidana, Rosângela Itri, do IF, Zara Issa Abud e Antônio Carlos Brolezzi do IME, Elysandra Figueiredo do IAG, Christiane Coutheux Trindade, Maurício Pietrocola e Ocimar Munhoz Alavarse da FE.

Gostaria de agradecer também à minha orientadora Maria Regina, mesmo que ela acredite que este agradecimento não é necessário, pois é obrigação da orientadora orientar. Sem ela, porém, este trabalho definitivamente não seria o mesmo, e eu não teria a oportunidade de tantas discussões e aprendizados.

Gostaria de agradecer à CAPES, pelos dois anos de bolsa, e aos contribuintes do estado de São Paulo e do Brasil, que, com seus impostos, financiam as bolsa de pósgraduação, os docentes, funcionários e estudantes da Universidade de São Paulo, universidade que deve ser pública em essência, apoiada em seus três pilares: ensino, pesquisa e extensão.

Sobre esta instituição, gostaria de agradecer a todos os seus funcionários, que desempenham as infinitas tarefas necessárias a seu funcionamento, mas também os profissionais ligados a limpeza, alimentação e segurança, frequentemente terceirizados e precarizados. Fica aqui o agradecimento especial aos funcionários Ademir Rodrigues, Alessandro Aparecido Brugnoli, Demóstenes Melo e Renata Ribeiro, tanto pelos serviços prestados, quanto pelas suas ações que vão além do campo profissional. Agradeço também a Maria Fernanda Araújo de Resende pelos inúmeros bons momentos.

Todo o trabalho para esta dissertação foi realizado em software livre, tanto no Mozilla Firefox, quanto no LibreOffice. A escolha pelo uso destes programas se deu não apenas por sua praticidade e gratuidade, mas principalmente por princípios de liberdade, privacidade e independência de empresas privadas. Fica o agradecimento, aqui, a toda a comunidade desenvolvedora destes programas.

Gostaria de agradecer, finalmente, a meu pai, Eliseo, minha mãe, Mariusa, meu irmão, Heitor e minha cunhada Renata, por todo o apoio, suporte, carinho, compreensão e paciência.

Muito obrigado a todas e todos, por me incomodarem, por me fazerem ser mais, por serem minhas mediações para com o mundo, ajudando na construção de quem eu sou. 
Você acredita nas mesmas coisas

Que você costumava acreditar?

Você está lá na frente de batalhas,

Ou em casa acumulando pontuação?

Você se importa em ser a camada

De tijolos que sela seu destino?

Ou você prefere ser o(a) arquiteto(a)

Daquilo que podemos criar? ${ }^{1}$

(BARNES et al., 2011)

1 Trecho traduzido da música “Architects”, da banda americana Rise Against, cujo original é:

"Do you still believe in all the things

That you stood by before?

Are you out there on the front lines

Or at home keeping score?

Do you care to be the layer

Of the bricks that seal your fate?

Or would you rather be the architect

Of what we might create?” 


\section{Resumo}

BONDEZAN, Guilherme Ventura. Perspectivas de cidadania articuladas com o conhecimento escolar de Física. 2019. 187 f. Dissertação (Mestrado em Ensino de Ciências - ênfase Física) - Instituto de Física, Instituto de Química, Instituto de Biociências, Universidade de São Paulo, São Paulo, 2019.

É nítida a necessidade de um ensino voltado para a promoção da cidadania, amplamente defendido pelos documentos oficiais que regulamentam a educação básica no Brasil e por aqueles envolvidos em seu processo de ensino-aprendizagem. Esta preocupação com a cidadania, que deve estar presente em todas as disciplinas, inclusive científicas, pode ser compreendida de diferentes maneiras. Assim, numerosas e diversificadas têm sido as contribuições da Pesquisa em Ensino de Ciências, envolvendo, dentre outras, abordagens denominadas Alfabetização Científica, Ciência, Tecnologia, Sociedade e Ambiente, Questões Sociocientíficas, Questões Controversas e Questões Socioambientais. É este rico cenário que motiva a presente investigação, que, além de buscar sua caracterização, tem como objetivo específico tornar as reflexões sobre cidadania no ensino de ciências acessíveis a um público mais amplo, especialmente professores da educação básica. Nesse sentido, foi realizada uma caracterização inicial (a partir de alguns artigos, livros, teses e dissertações), do ponto de vista teórico, dos pressupostos, objetivos e preocupações relativos às abordagens, para orientar uma análise mais aprofundada. A partir desse quadro, foi realizada uma investigação de caráter empírico com o intuito de identificar os encaminhamentos mais frequentes dados às abordagens presentes nas pesquisas, assim como dos principais aspectos eventualmente influenciadores das práticas em sala de aula. Para essa busca empírica, elegemos os trabalhos publicados no Encontro Nacional de Pesquisa em Educação em Ciências (ENPEC), no período 2013 a 2017, relativos ao tema, analisados segundo dois enfoques diferentes. Em um primeiro momento, foi desenvolvida uma caracterização geral, mais quantitativa, identificando quais as etapas da escolarização contempladas, a natureza dos trabalhos, as disciplinas de interesse, dentre outros aspectos. Em um segundo momento, numa caracterização mais qualitativa, foram analisados apenas os trabalhos que envolviam práticas em sala de aula, buscando identificar as intenções, os conhecimentos estudados, as motivações para sua escolha e as práticas encaminhadas. Nesses dois momentos, foi dado especial destaque aos propósitos educacionais priorizados pelos próprios autores, buscando articulá-los com os outros elementos da pesquisa. Do conjunto dos resultados dessas análises, foi possível caracterizar os principais elementos das práticas de sala de aula com potencial para inspirar e subsidiar professores que, em diferentes contextos, optem por buscar perspectivas de cidadania em suas atividades.

Palavras-chave: Alfabetização Científica. Cidadania. Ciência, Tecnologia, Sociedade e Ambiente. Questões Sociocientíficas. 


\begin{abstract}
BONDEZAN, Guilherme Ventura. Citizenship perspectives associated with the Physics scoolar knowledge. 2019. 187 f. Dissertação (Mestrado em Ensino de Ciências - ênfase Física) - Instituto de Física, Instituto de Química, Instituto de Biociências, Universidade de São Paulo, São Paulo, 2019.

There is a clear need for citizenship education, widely supported by the official documents that regulate basic education in Brazil and by those involved in its teaching-learning process. This concern with citizenship, which must be present in all disciplines, including scientific, can be understood in different ways. Thus, numerous and diverse have been the contributions of Research in Science Teaching, involving, among others, approaches called Scientific Literacy, Science, Technology, Society and Environment, Socioscientific Issues, Controversial Issues and Socio-Environmental Issues. It is this rich scenario that motivates the present investigation, which, besides seeking its characterization, has the specific objective to make the contributions on citizenship in science teaching accessible to a wider public, especially teachers of basic education. In this regard, an initial characterization was performed (based on some articles, books, theses and dissertations), from the theoretical point of view, of the assumptions, objectives and concerns related to the approaches, to guide a deeper analysis. From this framework, an empirical investigation was conducted to identify the most frequent referrals given to the approaches present in the research, as well as the main aspects that may influence classroom practices. For this empirical search, we chose the papers published in the Encontro Nacional de Pesquisa em Educação em Ciências (ENPEC), in the period 2013-2017, related to the theme, and analyze it according to two different approaches. At first, a more quantitative general characterization was developed, identifying which stages of schooling were contemplated, the nature of the research, the subjects of interest, among other aspects. In a second moment, in a more qualitative characterization, only the papers that involved classroom practices were analyzed, seeking to identify the intentions, the knowledge studied, the motivations for their choice and the practices forwarded. In these two moments, special emphasis was given to the educational purposes prioritized by the authors themselves, seeking to articulate them with the other elements of the research. From the set of results of these analyzes, it was possible to characterize the main elements of classroom practices with potential to inspire and support teachers who, in different contexts, choose to seek perspectives of citizenship in their activities.
\end{abstract}

Keywords: Scientific Literacy. Citizenship. Science, Tecnology, Society and Environment. Socioscientific Issues. 


\section{Índice de figuras}

Figura 1 - Relação entre parâmetros e propósitos da educação CTS........................................62

Figura 2 - Trabalhos segundos suas Ênfases no IX, X e XI ENPEC......................................79

Figura 3 - Propósitos Educacionais de todos os trabalhos do IX, X e XI ENPEC...................80

Figura 4 - Propósitos Educacionais nas Ênfases Adotadas no IX, X e XI ENPEC..................81

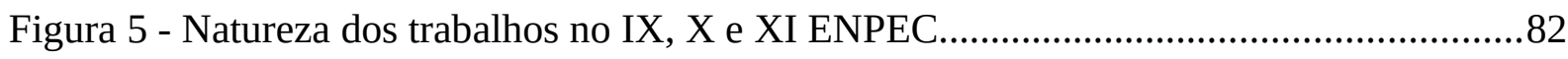

Figura 6 - Ênfase adotada por Natureza dos trabalhos no IX, X e XI ENPEC.........................83

Figura 7 - Ênfase por Nível de Ensino no IX, X e XI ENPEC...............................................85

Figura 8 - Propósitos Educacionais por Nível de Ensino no IX, X e XI ENPEC.....................86

Figura 9 - Ênfases por Temática dos trabalhos no IX, X e XI ENPEC....................................88

\section{Lista de tabelas}

Tabela 1 - Olhares sobre a Ciência, Tecnologia e Sociedade..................................................55

Tabela 2 - Níveis de compreensão sobre Racionalidade, Desenvolvimento e Participação.....58

Tabela 3 - Quantidade de trabalhos selecionados e total por evento.......................................67

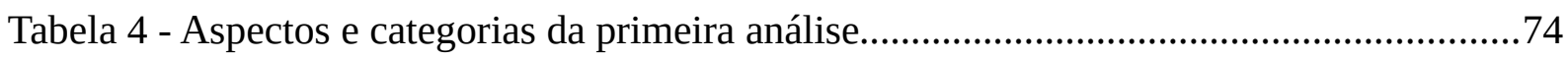

Tabela 5 - Trabalhos selecionados para a segunda análise....................................................75

Tabela 6 - Relação com a Sala de Aula e nível de ensino no IX, X e XI ENPEC....................84

Tabela 7 - Quantidade de trabalhos por Temática no IX, X e XI ENPEC...............................87

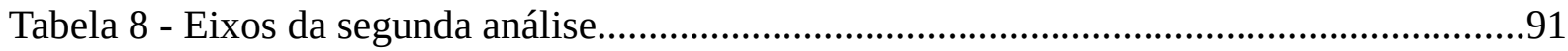

Tabela 9 - Ficha de análise do trabalho Moura e Comaru (2015)...........................................94

Tabela 10 - Eixos e categorias da segunda análise..............................................................96

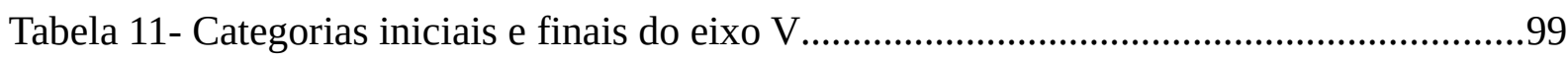

Tabela 12 - Ficha de análise do eixo I, “Tema de Referência”.............................................103

Tabela 13 - Ficha de análise do eixo II, "Relação do professor com o conhecimento científico”

Tabela 14 - Ficha de análise do eixo III, “Engajamento dos alunos”.... 108

Tabela 15 - Ficha de análise do eixo IV, “Atividades desenvolvidas em sala”. 
Tabela 16 - Ficha de análise do eixo V, "Participação na sociedade que os alunos desenvolvem"

Tabela 17 - Ficha de análise do eixo VI, “Contexto da prática docente”

Tabela 18 - Ficha de análise do eixo VII, “Cidadania apresentada pelos autores”.

Tabela 19 - Resumo das principais compreensões possíveis de AC, CTS(A) e Questões.

Tabela 20 - Resultados do eixo I, “Tema de Referência”.

Tabela 21 - Resultados do eixo II, “Relação do professor com o conhecimento científico”..138

Tabela 22 - Resultados do eixo III, “Engajamento dos alunos”. 139

Tabela 23 - Resultados do eixo IV, “Atividades desenvolvidas em sala”. 139

Tabela 24 - Resultados do eixo V, "Participação na sociedade que os alunos desenvolvem” 140

Tabela 25 - Resultados do eixo VI, “Contexto da prática docente”. 141

Tabela 26 - Resultados do eixo VII, “Cidadania apresentada pelos autores”. 142

Tabela 27 - Blocos do segundo panorama. 143

Tabela 28 - Propósitos Educacionais e Ênfases dos trabalhos da segunda análise. 159

Tabela 29 - Ficha de análise do trabalho Freitas et al. (2015)...............................................160

Tabela 30 - Ficha de análise do trabalho Vale, Souza e Firme (2015)...................................161

Tabela 31 - Ficha de análise do trabalho Souza e Martins (2015).........................................164

Tabela 32 - Ficha de análise do trabalho Nunes, Lindemann e Galiazzi (2015).....................165

Tabela 33 - Ficha de análise do trabalho Carvalho, Moreira e Aguiar Jr (2015)....................167

Tabela 34 - Ficha de análise do trabalho Cardoso et al. (2015)............................................169

Tabela 35 - Ficha de análise do trabalho Martins, Ribeiro e Ayres (2017)............................171

Tabela 36 - Ficha de análise do trabalho Batista, Assis e Travain (2017)..............................173

Tabela 37 - Ficha de análise do trabalho Terra e Leite (2017)...............................................175

Tabela 38 - Ficha de análise do trabalho Silva et al. (2017).................................................177

Tabela 39 - Ficha de análise do trabalho Santana, Terra e Leite (2017)................................179

Tabela 40 - Ficha de análise do trabalho Pereira et al. (2017)..............................................180

Tabela 41 - Ficha de análise do trabalho Martinez et al. (2017)............................................182

Tabela 42 - Ficha de análise do trabalho Santos et al. (2017).................................................184

Tabela 43 - Ficha de análise do trabalho Fadini e Leite (2017)............................................185 


\section{Índice}

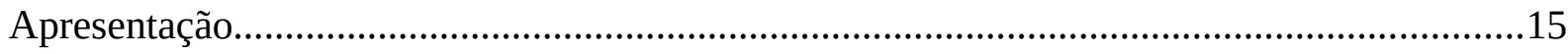

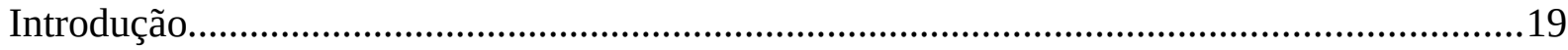

Capítulo 1 - Diferentes perspectivas de cidadania................................................................24

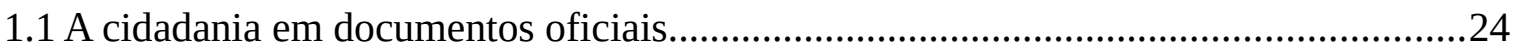

1.2 Contexto social e político em que a cidadania é exercida..........................................28

1.3 Aspectos específicos das Ciências e sua dinâmica.....................................................33

1.4 Abordagens para a Cidadania na Pesquisa em Ensino de Ciências..............................35

Capítulo 2 - Diferentes ênfases para a cidadania....................................................................38

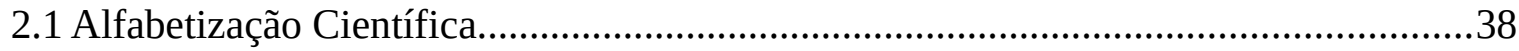

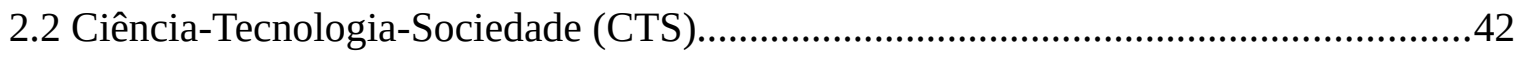

2.3 Questões Sociocientíficas (QSC).......................................................................47

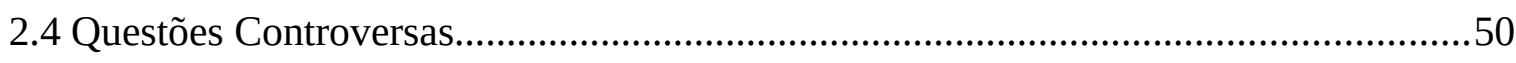

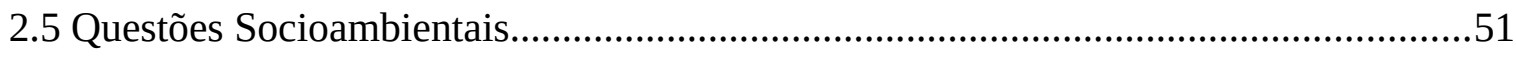

Capítulo 3 - Referencial para compreender as perspectivas educacionais..............................53

Capítulo 4 - Metodologia utilizada na compreensão das abordagens visando a cidadania......64

4.1 Estado do conhecimento: corpus de análise...............................................................66

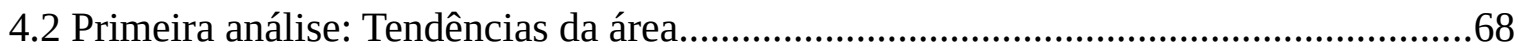

4.3 Segunda análise: Fatores influenciadores da prática em sala de aula.........................74

Capítulo 5 - Tendências da Pesquisa em Ensino de Ciências voltada à cidadania....................78

Capítulo 6 - Principais influências das atividades didáticas voltadas à cidadania...................90

6.1 Identificação dos principais aspectos influenciadores das práticas em sala de aula....90

6.2 Diferentes formas de colocar em prática os aspectos influenciadores.......................102

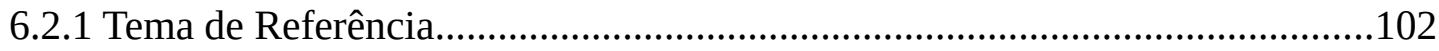

6.2.2 Relação do professor com o conhecimento científico....................................104

6.2.3 Engajamento dos alunos...........................................................................107

6.2.4 Atividades desenvolvidas em sala..........................................................111

6.2.5 Participação na sociedade que os alunos desenvolvem..................................115

6.2.6 Contexto da prática docente.........................................................................119

6.2.7 Cidadania apresentada pelos autores.........................................................121

Capítulo 7 - As diferentes formas de promoção da cidadania na sala de aula.........................127 
7.1 As abordagens recorrentes na Pesquisa em Ensino de Ciências preocupadas com a

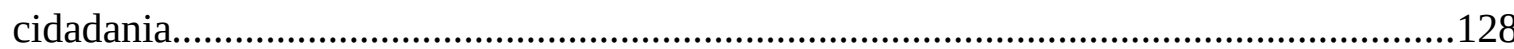

7.2 Aproximações entre as abordagens preocupadas com a cidadania...........................132

7.3 Aspectos influenciadores das práticas preocupadas com a cidadania.......................135

7.4 Panorama sintético das influências das práticas preocupadas com a cidadania..........143

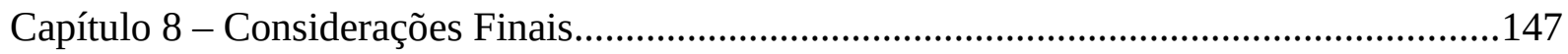

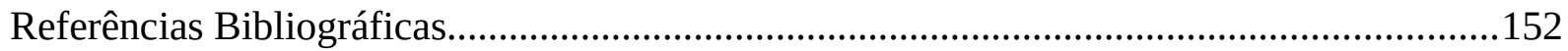

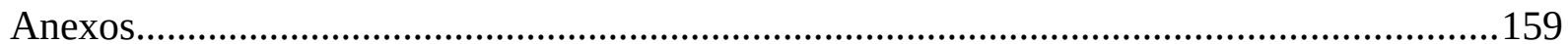




\section{Apresentação}

Desde criança me interessei por tecnologia, tanto com meu primeiro vídeo game, um Super Nintendo, que eu jogava numa TV de tubo de 14”, quanto meu primeiro MP3, de 128 MB, meu primeiro computador, com Windows 98 e meu primeiro celular, o lendário Nokia 3310. Mesmo agora continuo fascinado por computadores, software livre e o mundo novo do Linux.

Além da tecnologia, na forma de equipamentos eletrônicos, me interessei, também, por eletricidade, na forma de fios, interruptores, disjuntores e lâmpadas na manutenção da rede elétrica de casa, influenciado pelo meu pai.

No que diz respeito à escola, sempre tive facilidade com Matemática, tanto no Ensino Fundamental e Médio, quanto no curso Kumon.

Ao final do Ensino Médio escolhi uma carreira que estava ligada ao meu perfil, mas que também me proporcionasse um retorno financeiro. Escolhi, assim, engenharia, inicialmente Elétrica e depois da Computação. O vestibular chegou, mas eu não passei. Fiz um ano de cursinho do mais bancário possível e, novamente, não passei. Fiz, então, mais um ano do mesmo cursinho e, mesmo tendo estudado e aprendido muito, novamente não passei.

Nesse momento percebi que não poderia aguentar mais um ano daquela desgastante rotina, daquela neurose, daquela competição, sem falar dos custos, mesmo que minha família nunca tivesse reclamado. A FUVEST daquele ano (vestibular da Universidade de São Paulo), 2012, contudo, começou a adotar a reescolha, em que o candidato poderia escolher, após a terceira chamada, um outro curso com vagas remanescentes. Escolhi, assim, Licenciatura em Física.

Vale a pena mencionar que, embora a realidade do cursinho fosse muito desgastante, tive vários bons professores, principalmente de Física, Química, Biologia e Literatura, que me mostraram muitos mundos novos. Nesta época comecei a me ver neles, a me sentir inspirado por eles, a querer ser eles. É verdade que depois de alguns anos do curso de Licenciatura não mais os considerei da mesma forma, mas pude perceber a importância daqueles conhecimentos, que me enriqueceram como um todo.

Cursei o primeiro semestre da Licenciatura de maneira um tanto burocrática, mas no segundo semestre, na disciplina de POEB (Política e Organização da Educação Básica no Brasil), a professora me mostrou o cenário de penúria da educação pública do Brasil. Mesmo que eu tivesse passado seis anos de minha vida em escola pública, ter uma melhor noção 
desse cenário me motivou a "comprar essa briga”, a tomar a melhoria da escola pública como um objetivo de vida.

No decorrer da Licenciatura, várias foram as disciplinas que me motivaram a continuar nela, como Elementos e Estratégias para o Ensino de Física, Propostas e Projetos e Produção de Material Didático, ministradas pelo professor Cristiano Mattos. Foi durante esta última disciplina, também, que formamos a Comissão do Encontro da Licenciatura, comissão formada por alunos e alunas da graduação para organizar um evento dedicado a discutir temas da atividade docente não apresentados durante a graduação.

Me marcaram, também, as disciplinas de Evolução dos Conceitos de Física, Tópicos de História de Física Clássica e Ciência e Cultura, ministradas pelo professor Ivã Gurgel. Nesta disciplina, conheci o trabalho de Pierre Bourdieu, que me afetou profundamente quando afirma que a indiferença das pessoas e da escola é suficiente para agravar as desigualdades existentes na sociedade.

Mais ao final da graduação, durante o trabalho de monografia (BONDEZAN, 2016), tive contato com a ênfase Ciência, Tecnologia e Sociedade (CTS), da Pesquisa em Ensino de Ciências, que complexificou a minha noção de sociedade, desvelando as instituições nela presentes, os conflitos de interesses envolvidos e a relação desta com a Ciência e a Tecnologia.

Durante a pesquisa que teve como foco a ênfase CTS, encontrei, também, trabalhos que apresentavam outras denominações, como "alfabetização científica”, “questões sociocientíficas” e “questões controversas”, estando estes trabalhos inclusive agrupados nas mesmas seções que os com ênfase CTS e não raramente fazendo menção a estes termos no corpo do texto.

Era evidente que havia uma relação entre estas expressões, mas esta relação, além de não evidente em um primeiro momento, apresenta-se de maneira um tanto desafiadora e intimidadora. Isto pode fazer tanto com que haja compreensões superficiais, simplificadas e distorcidas dessas expressões, levando a práticas educacionais rasas e acríticas, quanto a suposição de que elas são sinônimos.

Principalmente durante meus primeiros contatos com a Pesquisa em Ensino de Ciências, tive muitas ressalvas quanto ao papel da teoria na prática docente, isto é, várias vezes tive a impressão de que a teoria se distancia da prática de tal maneira que se torna apenas uma grande conjectura, muito bonita e funcional dentro da literatura e da universidade, fechada dentro de sua bolha, mas completamente inviável e inútil dentro do ambiente escolar das escolas públicas. 
São estas duas as principais motivações do presente trabalho, isto é, compreender a desafiadora multiplicidade de denominações de ênfases que têm como foco a relação Ciência e Sociedade e o compromisso em dialogar com a realidade da sala de aula, para impedir que a pesquisa realizada tenha um fim em si mesma. 


\section{Introdução}

É bastante evidente um cenário de crise no ensino básico público brasileiro. Esta crise pode ser verificada pelos inúmeros casos de violência escolar, no analfabetismo funcional de grande parcela da população, que inclusive tem grande dificuldade de interpretar textos e de realizar cálculos de matemática básica, no baixo desempenho dos estudantes em avaliações de larga escala nacionais e internacionais e na alta evasão, principalmente nas etapas finais da escolarização obrigatória.

São vários os motivos para a existência deste cenário, comparecendo em diferentes intensidades, as dimensões políticas, econômicas, sociais, assim como muitas outras. A decisão sobre qual seria a finalidade da educação está diretamente associada com várias dessas dimensões, assim como, em alguma medida, com a crise da educação.

São várias as finalidades possíveis para a escolarização básica, e elas se relacionam com os diferentes perfis de alunos que se deseja formar. Apesar destas finalidades serem, em alguma medida, opostas, elas acabam coexistindo dentro do ambiente escolar. Dentre estas finalidades, destacamos a educação propedêutica, a preparatória para o vestibular, a profissionalizante e a voltada para a promoção da cidadania.

A educação propedêutica busca preparar os estudantes para o ensino superior, fornecendo conhecimentos que serão usados e aprofundados naquele nível de ensino. Apesar desta finalidade da educação contrariar a lei de diretrizes e bases da educação (LDB) (BRASIL, 1996), ela ainda é praticada, com diferentes intensidades, nas escolas de nosso país.

Diante da grande concorrência no ingresso em alguns cursos de ensino superior, surge um tipo de educação que busca preparar os estudantes exclusivamente para os vestibulares e para o Exame Nacional do Ensino Médio (ENEM), suas formas de seleção, dando para o final da escolarização básica um objetivo bastante definido.

A educação profissionalizante, por sua vez, busca preparar os estudantes para o mercado de trabalho. Esta preparação daria ao estudante melhor capacidade de desempenhar diferentes profissões, aumentando a sua renda e melhorando suas chances de sucesso profissional. Além disso, ao produzir mão de obra especializada, esta educação dinamizaria a economia do país, levando ao seu crescimento. 
Além destas funções da escolarização e muitas outras, temos a que busca uma formação para a vida em sociedade, isto é, para a execução da cidadania. Uma educação com este objetivo busca incentivar os alunos a participarem em elementos centrais da democracia, como a elaboração e votação de leis, regulamentação de empresas e na emissão de pareceres sobre obras de grande impacto social, econômico e ambiental.

Esta função para a educação, em alguma medida, se afasta das outras, mas, na prática, acaba se sobrepondo às outras e motivando as atividades escolares. Isto acontece, pois o ambiente escolar está sujeito a pressões de todas as naturezas, realizadas pelos vários grupos que compõe sua comunidade, como professores, diretores, gestores e políticos, assim como alunos e familiares.

Estas funções para a escolarização, além de incentivadas na prática, são regulamentadas por vários documentos oficiais. Este é o caso, por exemplo, da Constituição da República Federativa do Brasil (BRASIL, 1988, p. 123), que, em seu artigo 205, na Seção I e no Capítulo III, que versa sobre a Educação, afirma

A educação, direito de todos e dever do Estado e da família, será promovida e incentivada com a colaboração da sociedade, visando ao pleno desenvolvimento da pessoa, seu preparo para o exercício da cidadania e sua qualificação para o trabalho.

Este trecho da constituição defende que a educação deve ser pensada como preparando os alunos para o exercício da cidadania, mas, além disso, defende a educação como voltada a qualificar seus alunos para o mercado de trabalho, evidenciando que estes objetivos, apesar de alguma maneira antagônicos, são capazes de influenciar simultaneamente as práticas escolares.

Além da Constituição da República Federativa do Brasil, a cidadania aparece e é incentivada, também, por outros documentos, como a lei número 9.394 de 20 de Dezembro de 1996, que estabelece as diretrizes e bases da educação nacional (LDB) (BRASIL, 1996), o Plano Nacional de Educação (PNE) de 2014 (BRASIL, 2014) e a Base Nacional Comum Curricular (BNCC) (BRASIL, 2017a). Isto demonstra que a preparação para o exercício da cidadania é, de fato, um objetivo muito relevante para a educação.

Esta educação voltada para a cidadania, porém, apesar de amplamente defendida nos documentos oficiais e pelos diversos atores sociais dentro do setor educacional, é polissêmica, podendo ser compreendida de diferentes maneiras.

Dentro dos próprios documentos oficiais é possível encontrar tanto concepções de cidadania amplas e pouco detalhadas, quanto concepções associadas aos valores morais e 
éticos, a realização de escolhas com consciência crítica e responsabilidade e, ainda, ações pessoais e coletivas com autonomia e responsabilidade com base em princípios democráticos, inclusivos, sustentáveis e solidários.

Estas distintas formas de se compreender a cidadania existem, também, pois não é possível desprezar os diferentes contextos políticos em que se está inserido, isto é, as liberdades políticas individuais e sociais que gozam seus cidadãos.

No que diz respeito especificamente ao ensino de ciências, as concepções de cidadania podem levar em conta diferentes concepções de ciência, que podem ser simplórias e dogmáticas ou complexas e conscientes do seu modo de desenvolvimento, de suas interrelações com a sociedade, entre outros fatores.

São várias as formas de se colocar em prática uma educação visando a cidadania no ensino de ciências, sendo muitos os encaminhamentos possíveis. A cidadania pode ser trabalhada, por exemplo, tanto em uma dimensão mais localizada, incentivando os estudantes a realizarem escolhas a respeito da reciclagem e do descarte de lixo em suas casas ou escola, quanto em uma dimensão mais geral, incentivando os estudantes a redigir projetos de lei que regulamentem a emissão de poluentes, passando por tramitação em câmaras municipais e assembleias legislativas ou acontecendo apenas em caráter simulado.

A motivação da presente pesquisa é, precisamente, este cenário de múltiplas compreensões do conceito de cidadania e as várias formas como ela pode ser colocada em prática no ensino de ciências.

A produção acadêmica da Pesquisa em Ensino de Ciências voltada à promoção da cidadania é bastante extensa, com centenas de pesquisadores refletindo sobre os rumos que deve tomar, relatando e analisando atividades desenvolvidas com diferentes encaminhamentos. Apesar de todo este esforço por parte dos pesquisadores, nem sempre todas estas reflexões chegam a um público mais amplo, como professores da educação básica.

O objetivo desta pesquisa é, portanto, entender a multiplicidade de compreensões de cidadania e a forma como elas são implementadas, tendo como base a produção acadêmica em ensino de ciências, e construir um diálogo com os professores em exercício, para que esta produção seja aproveitada por mais docentes e possa auxiliá-los em suas atividades didáticas.

Neste diálogo, os professores serão incentivados a realizar escolhas metodológicas conscientes e sem desconsiderar as inúmeras especificidades a que estão sujeitos, como suas 
turmas de alunos, a coordenação pedagógica da escola em que lecionam e suas visões de educação.

Para a construção deste diálogo, inicialmente, no Capítulo 1, levantamos algumas das dimensões importantes para compreender as várias concepções de cidadania. Estas dimensões são o que é defendido pelos documentos oficiais; quais os aspectos políticos e democráticos que limitam ou incentivam a liberdade para exercício da cidadania; concepções limitadas ou complexas da ciência e sua dinâmica; e algumas das abordagens que aparecem de maneira recorrente na Pesquisa em Ensino de Ciências voltada à cidadania.

No Capítulo 2 são descritas e detalhadas algumas das abordagens recorrentes dedicadas à promoção da cidadania, a saber, Alfabetização Científica, Ciência, Tecnologia e Sociedade, Questões Sociocientíficas, Questões Controversas e Questões Socioambientais. Para esta descrição, nos usamos dos pressupostos teóricos que guiam estas abordagens, encontrados em artigos de revistas, livros, teses e dissertações e evidenciamos, sempre que possível, aproximações e discordâncias.

Como forma de compreender e sistematizar as aproximações e divergências entre as abordagens que visam a cidadania, nos usamos de uma matriz de referência, a ser detalhada no Capítulo 3. Os Propósitos Educacionais, uma das dimensões desta matriz, serão essenciais para sistematizar as abordagens voltadas à cidadania e para a construção do diálogo com os professores.

Além da compreensão das diversas abordagens voltadas à cidadania a partir de seus pressupostos teóricos, realizamos, também, uma busca na forma como estes pressupostos são colocados em prática. Para tanto, tomamos por base os trabalhos publicados no Encontro Nacional de Pesquisa em Educação em Ciências (ENPEC) que faziam menção às abordagens de interesse e realizamos duas análises distintas, cujas amostras, metodologias, eixos de análise e categorias são detalhados no Capítulo 4.

A primeira dessas análises, cujos resultados são apresentados e discutidos no Capítulo 5, se usa de uma amostra mais ampla e de um tratamento mais quantitativo de dados, buscando identificar as tendências das cinco abordagens destacadas, assim como possíveis afinidades com níveis de escolarização, disciplinas científicas, etc. Como forma de sistematização dos vários encaminhamentos das atividades, nos utilizamos dos Propósitos Educacionais, descritos no Capítulo 3. 
A segunda análise teve como amostra os trabalhos do ENPEC que propunham ou analisavam atividades para a sala de aula voltadas à cidadania. Nesta análise, cujos resultados são apresentados no Capítulo 6, buscamos identificar os principais fatores que influenciam estas atividades, como o contexto em que elas se situam, a forma como a cidadania é incentivada através dos conteúdos estudados, quais as ações dos alunos em sala de aula, entre outros fatores.

No Capítulo 7, finalmente, serão discutidos e articulados os elementos apresentados no decorrer da dissertação, tendo a intenção de se aproximar da prática docente e a construção de um diálogo. Este diálogo, que não desconsiderará as inúmeras peculiaridades dos contextos de atuação dos professores e valorizará sua autonomia e liberdade, destacará os principais fatores que influenciam uma prática voltada à cidadania, assim como as formas que este objetivo da educação é frequentemente pensado dentro da Pesquisa em Ensino de Ciências, tendo potencial de ser utilizado para auxiliar práticas futuras em sala de aula.

Finalmente, no Capítulo 8, serão apresentadas as Considerações Finais da presente pesquisa, contando, além de um breve resumo do que foi realizado, de algumas considerações sobre as contribuições apresentadas, as inquietações que emergiram e algumas das potencialidades identificadas para pesquisas futuras. 


\section{Capítulo 1 - Diferentes perspectivas de cidadania}

Diante das múltiplas compreensões possíveis a respeito da cidadania, algumas dimensões se mostram importantes e precisam ser consideradas para compreender a produção acadêmica destinada à sua promoção, assim como incentivar de forma consciente as práticas em sala de aula com este fim.

Em primeiro lugar temos o que é defendido e regulamentado nos vários documentos oficiais, como leis, diretrizes, planos de educação e parâmetros curriculares, fornecendo uma aproximação inicial de algumas compreensões do conceito de cidadania e de como ela pode ser abordada na sala de aula.

Em segundo lugar, há a dimensão sobre o contexto em que a cidadania é exercida, isto é, os diferentes contextos políticos que limitam ou incentivam práticas em sociedade, fornecendo maiores ou menores liberdades políticas individuais ou coletivas aos cidadãos.

Em terceiro lugar, mais próximas do Ensino de Ciências propriamente dito, temos dimensões associadas às distintas compreensões de Ciências e sua dinâmica. Embora estas dimensões sejam um tanto distantes da cidadania, dizem respeito a elementos importantes da dinâmica da Ciência que, quando presentes em atividades práticas voltadas à cidadania, podem implicar encaminhamentos bastante diferentes.

Finalmente, em quarto lugar, temos algumas abordagens dedicadas ao incentivo da cidadania que aparecem de maneira recorrente dentro da área de Pesquisa em Ensino de Ciências. Estas abordagens se relacionam, de alguma maneira, com as dimensões aqui mencionadas e colocam em prática de maneiras distintas a promoção da cidadania.

\subsection{A cidadania em documentos oficiais}

Embora a cidadania brasileira como existe hoje seja bastante recente, iniciando-se ao longo do processo de redemocratização na década de 1980, foi compreendida de diversas formas ao longo da história de nosso país. Muito antes da redemocratização já ocorriam eleições indiretas e diretas, com colégio eleitoral sendo ampliado sucessivamente para incluir homens de baixa renda, analfabetos, mulheres e garantir o sigilo do voto. 
Além, do voto propriamente dito, temos a cidadania compreendida como associada aos símbolos nacionais, como hinos, bandeiras, comemorações festivas de independência e proclamação da república e às forças armadas. Estes símbolos nacionais estiveram presentes, em alguma medida, durante toda a história do Brasil, compondo o imaginário de nação, o patriotismo e a cidadania.

Especificamente considerando o atual momento histórico brasileiro, temos vários documentos oficiais defendendo e regulamentando a cidadania e a importância de uma educação com este fim.

A lei número 9.394 de 20 de Dezembro de 1996, por exemplo, estabelece as diretrizes e bases da educação nacional (LDB) (BRASIL, 1996), afirmando, em seu artigo segundo do Título II, sobre os Princípios e Fins da Educação Nacional, que

\begin{abstract}
A educação, dever da família e do Estado, inspirada nos princípios de liberdade e nos ideais de solidariedade humana, tem por finalidade o pleno desenvolvimento do educando, seu preparo para o exercício da cidadania e sua qualificação para o trabalho.
\end{abstract}

A mesma lei, em seu artigo 22 da Seção I, sobre as Disposições Gerais, no Capítulo II, destinado à Educação Básica, no Título V, sobre os Níveis e as Modalidades de Educação e Ensino, afirma

A educação básica tem por finalidades desenvolver o educando, assegurarlhe a formação comum indispensável para o exercício da cidadania e fornecer-lhe meios para progredir no trabalho e em estudos posteriores.

A mesma lei, em seu artigo 35 na Seção IV, sobre o Ensino Médio, no mesmo Capítulo e Título, afirma que

Art. 35. O ensino médio, etapa final da educação básica, com duração mínima de três anos, terá como finalidades:

II - a preparação básica para o trabalho e a cidadania do educando, para continuar aprendendo, de modo a ser capaz de se adaptar com flexibilidade a novas condições de ocupação ou aperfeiçoamento posteriores;

Os Parâmetros Curriculares Nacionais para o Ensino Médio (PCNEM), apesar de não mais estarem em vigor, também defendem uma formação voltada ao exercício da cidadania. Essa defesa aparece tanto em sua primeira parte sobre as Bases Legais, quanto na terceira, sobre as Ciências da Natureza, Matemática e suas Tecnologias (BRASIL, 1999), assim como nas Orientações Educacionais Complementares aos Parâmetros Curriculares Nacionais $(\mathrm{PCN}+)$, em seu volume destinado às Ciências da Natureza, Matemática e suas Tecnologias (BRASIL, 2002). 
A partir da LDB (BRASIL, 1996), as Bases Legais do PCNEM advogam que (BRASIL, 1999, p. 80):

Desde logo, é preciso que a proposta pedagógica assuma o fato trivial de que a cidadania não é dever nem privilégio de uma área específica do currículo, nem deve ficar restrita a um projeto determinado. Exercício de cidadania é testemunho que se inicia na convivência cotidiana e deve contaminar toda a organização curricular. As práticas sociais e políticas e as práticas culturais e de comunicação são parte integrante do exercício cidadão, mas a vida pessoal, o cotidiano e a convivência e as questões ligadas ao meio ambiente, corpo e saúde também. Trabalhar os conteúdos das Ciências Naturais no contexto da cidadania pode significar um projeto de tratamento da água ou do lixo da escola ou a participação numa campanha de vacinação, ou a compreensão de por que as construções despencam quando os materiais utilizados não têm a resistência devida. E de quais são os aspectos técnicos, políticos e éticos envolvidos no trabalho da construção civil.

A formação para a cidadania aparece, também, como duas das diretrizes do Plano Nacional de Educação (PNE) de 2014 (BRASIL, 2014, p. 43), aprovado na forma da lei número 13.005 de 25 de Junho de 2014. Este instrumento de planejamento do Estado, com vigência de dez anos, tendo por objetivo orientar a execução e o aprimoramento de políticas públicas do setor de educação, afirma

Art. $2^{\circ}$ São diretrizes do PNE:

III - superação das desigualdades educacionais, com ênfase na promoção da cidadania e na erradicação de todas as formas de discriminação;

$\mathrm{V}$ - formação para o trabalho e para a cidadania, com ênfase nos valores morais e éticos em que se fundamenta a sociedade;

Finalmente, a Base Nacional Comum Curricular (BNCC) (BRASIL, 2017a), documento de caráter normativo, previsto pela LDB, após sua alteração com a lei número 13.415 de 16 de Fevereiro de 2017 (BRASIL, 2017b) e previsto pelo PNE de 2014 (BRASIL, 2014, p. 51), tem como objetivo definir o conjunto orgânico e progressivo de aprendizagens essenciais que todos os alunos devem ter para que os estudantes desenvolvam dez competências gerais. Uma dessas competências é (BRASIL, 2017a, p. 9):

Valorizar a diversidade de saberes e vivências culturais e apropriar-se de conhecimentos e experiências que lhe possibilitem entender as relações próprias do mundo do trabalho e fazer escolhas alinhadas ao exercício da cidadania e ao seu projeto de vida, com liberdade, autonomia, consciência crítica e responsabilidade.

Há, além dessa, pelo menos outra competência com íntima relação com o exercício da cidadania, mesmo que esta expressão não seja mencionada (BRASIL, 2017a, p. 10): 
Agir pessoal e coletivamente com autonomia, responsabilidade, flexibilidade, resiliência e determinação, tomando decisões com base em princípios éticos, democráticos, inclusivos, sustentáveis e solidários.

Além dessas competências gerais, a BNCC prevê também as competências específicas para cada uma das quatro áreas do conhecimento. Para a área de Ciências da Natureza e suas Tecnologias, temos três competências específicas (BRASIL, 2017a, p. 539):

1. Analisar fenômenos naturais e processos tecnológicos, com base nas relações entre matéria e energia, para propor ações individuais e coletivas que aperfeiçoem processos produtivos, minimizem impactos socioambientais e melhorem as condições de vida em âmbito local, regional e/ou global.

2. Construir e utilizar interpretações sobre a dinâmica da Vida, da Terra e do Cosmos para elaborar argumentos, realizar previsões sobre o funcionamento e a evolução dos seres vivos e do Universo, e fundamentar decisões éticas e responsáveis.

3. Analisar situações-problema e avaliar aplicações do conhecimento científico e tecnológico e suas implicações no mundo, utilizando procedimentos e linguagens próprios das Ciências da Natureza, para propor soluções que considerem demandas locais, regionais e/ou globais, e comunicar suas descobertas e conclusões a públicos variados, em diversos contextos e por meio de diferentes mídias e tecnologias digitais de informação e comunicação (TDIC).

Cada uma das três competências específicas têm alguma relação com o exercício da cidadania, tanto a primeira e a terceira, quanto a segunda, já que a tomada de decisões éticas e responsáveis também é elemento central quando se deseja um respeito entre os indivíduos que compõem uma sociedade.

Cada uma dessas competências específicas está associada a um determinado número de habilidades, isto é, ações que os alunos devem ser capazes de realizar, se valendo, para isso, de conteúdos e atividades proporcionadas pelas atividades escolares. As habilidades, assim, estão muito mais próximas dos conteúdos curriculares disciplinares de Física, Química e Biologia.

Do total de 23 habilidades específicas da área de Ciências da Natureza e suas Tecnologias, várias são as que têm alguma relação com a cidadania e o modo como os alunos podem exercê-la em sociedade, como é o caso das EM13CNT104, EM13CNT105, EM13CNT106, EM13CNT206, EM13CNT301, EM13CNT302, EM13CNT304, EM13CNT305 е EM13CNT309.

A título de exemplo, citamos as habilidades EM13CNT106 e EM13CNT304 (BRASIL, 2017a, p. 541 e 545): 
(EM13CNT106) Avaliar tecnologias e possíveis soluções para as demandas que envolvem a geração, o transporte, a distribuição e o consumo de energia elétrica, considerando a disponibilidade de recursos, a eficiência energética, a relação custo/benefício, as características geográficas e ambientais, a produção de resíduos e os impactos socioambientais.

(EM13CNT304) Analisar e debater situações controversas sobre a aplicação de conhecimentos da área de Ciências da Natureza (tais como tecnologias do DNA, tratamentos com células-tronco, produção de armamentos, formas de controle de pragas, entre outros), com base em argumentos consistentes, éticos e responsáveis, distinguindo diferentes pontos de vista.

Do ponto de vista formal, os documentos oficiais aqui apresentados têm uma diferença quanto ao seu caráter normativo. Documentos como a LDB e o PNE são normativos, isto é, regulamentam como a cidadania deve ser colocada em prática na educação básica. Os PCN e BNCC, por sua vez, não são normativos, apenas apontando algumas maneiras como a cidadania pode ser concebida e incentivada na sala de aula.

Além da diferença quanto a normatividade destes documentos, fica claro, também, a diferença nos modos como a cidadania é por eles concebida e incentivada. Na LDB e no PNE, a cidadania é incentivada de maneira um tando geral, sem maiores detalhamentos do que ela seria e de como ela poderia ser colocada em prática. Nos PCN e na BNCC, contudo, há um maior cuidado na definição de cidadania e de como ela pode ser incentivada, considerando as especificidades das diferentes disciplinas da educação básica e seus conteúdos curriculares.

Vale a pena mencionar, finalmente, que os documentos oficiais e as legislações, quando amplamente debatidos e aprovados num contexto democrático, refletem o campo de disputa em que estão inseridos, refletindo as concepções e interesses, frequentemente antagônicos, das pessoas envolvidas em sua elaboração. Todos os documentos aqui apresentados refletem conflitos de interesses, assim como as Diretrizes Curriculares Nacionais da Educação Básica (DCN), principalmente ao se comparar suas edições de 1998 e 2013 (BRASIL, 1998a; 1998b; 2013).

\subsection{Contexto social e político em que a cidadania é exercida}

As práticas em sala de aula voltadas à promoção da cidadania não podem, simplesmente, ignorar o contexto social, político e econômico em que estão inseridas. Diferentes contextos políticos podem limitar ou incentivar de maneiras distintas as práticas 
voltadas à cidadania, concedendo liberdades políticas individuais maiores ou menores, assim como a possibilidade de se organizar ou não em movimentos sociais e agir coletivamente.

Nesta direção, acreditamos que os trabalhos de Toti (2011), Pinhão (2014) e Pinhão e Martins (2016) problematizam a relação entre o ensino de Ciências e a cidadania, apresentando contribuições relevantes, apesar de suas naturezas distintas. Dentre as várias contribuições destes trabalhos, daremos mais atenção aos modelos políticos identificados pelos autores e às finalidades possíveis da educação voltada a cidadania. Apesar dos modelos políticos serem construídos através de percursos diferentes e serem usados com objetivos bastante diversos, são várias as aproximações entre eles.

No primeiro destes trabalhos, o autor realiza "uma pesquisa de natureza teórico bibliográfica fundamentada em elementos da sociologia” (TOTI, 2011, p. 6), buscando identificar as concepções de cidadania e as relações estabelecidas entre Educação em Ciências e cidadania em artigos publicados em revistas nacionais e internacionais de Educação em Ciências.

O autor, a partir de leituras do campo da sociologia, identifica cinco formas de cidadania, descritas a seguir:

i) Cidadania e teoria liberal: A teoria liberal está intimamente ligada ao direito à propriedade privada, à vida e à liberdade de seus indivíduos. Nesta teoria o Estado deve interferir o mínimo possível na economia e na vida de seus cidadãos, não se dedicando a combater as desigualdades econômicas existentes.

ii) Cidadania no comunitarismo: Nesta forma de cidadania, é privilegiado o bem-estar geral da população e as obrigações dos indivíduos em detrimento da liberdade individual dos cidadãos. Há um incentivo, aqui, de um pensamento em comunidade e uma valorização das virtudes.

iii) Cidadania e republicanismo cívico: O republicanismo cívico, por sua vez, busca um equilíbrio entre os direitos e as obrigações dos indivíduos, sendo necessário, para isso, a existência do Estado de Direito e a distribuição de riquezas.

iv) Cidadania e republicanismo participativo: Este modelo se constitui como um meio termo entre o liberalismo e o comunitarismo, defendendo a ampliação de direitos principalmente para as porções da população mais à margem da sociedade, como negros, mulheres e imigrantes. Há uma grande influência, neste modelo, do filósofo e sociólogo 
alemão Jürgen Habermas, que ressalta a importância da comunicação dos cidadãos e da sua participação em sociedade por meio de enquetes deliberativas.

v) Cidadania na pós-modernidade: Nesta forma de cidadania, finalmente, temos uma grande influência do pensamento pós-moderno. Embora sejam várias as correntes de pensamento nesta forma de cidadania, é comum uma fragmentação nas vozes de negros, mulheres, ambientalistas, indígenas, entre outros, assim como um reconhecimento de que um eventual fim do capitalismo não será suficiente para eliminar todas as desigualdades sociais. Embora o pós-modernismo busque se afastar do capitalismo, alguns de seus discursos são frequentemente apropriados por grandes empresas capitalistas, como o feminismo e o ambientalismo.

Além dessas cinco formas de cidadania, o autor identifica, a partir da leitura de artigos de revistas de ensino de ciências, seis objetivos da Educação em Ciências ou formas como os trabalhos de ensino de ciências incentivavam a cidadania. São eles:

- Superar uma ruptura democrática com foco no cisma político ciência-cidadão;

- Promover engajamentos políticos (ativismo) com foco na ação política direta;

- Superar uma ruptura epistemológica com foco no cisma cognitivo ciência-cidadão;

- Promover a sustentabilidade ambiental;

- Promover a igualdade racial e preservar a diversidade cultural;

- Superar uma ruptura epistemológica a partir do hibridismo cultural ciência-saberes gerados no contexto da comunidade. (TOTI, 2011, p. 104-105)

Essas seis formas como a cidadania pode ser incentivada foram reunidas, posteriormente, em quatro preocupações do ensino de ciências, a saber: emergência de um impulso na cidadania, incluindo as duas primeiras formas de incentivo da cidadania; a emergência de um impulso cognitivo, incluindo apenas a terceira forma; a emergência da questão ambiental, incluindo apenas a quarta forma; e a emergência da questão multicultural, incluindo as últimas duas formas de incentivo da cidadania.

Pinhão (2014), assim como seu posterior recorte (PINHÃO e MARTINS, 2016), tem como objetivo analisar como a relação entre o ensino de ciências e a cidadania é recontextualizada por professores dos primeiros anos da educação básica brasileira, se usando, para isso, de discussões em grupos e da análise crítica do discurso.

Para a realização desta análise, que será de cunho microssocial, as autoras situam o contexto macrossocial, na forma dos diferentes discursos sobre cidadania que circulam em 
nossa sociedade de forma geral, assim como as apropriações desses discursos em diferentes momentos da história da educação brasileira de maneira mais ampla e na história do ensino de ciências de maneira mais específica.

As autoras, nestes trabalhos, identificam discursos sobre a cidadania que se aproximam em grande medida das cinco formas de cidadania reunidas por Toti (2011), mesmo que não haja menção explícita àquele trabalho e mesmo que seus objetivos mais gerais sejam diferentes. As finalidades da educação demarcadas pelas autoras, contudo, apresentam relação mais indireta com as de Toti (2011), muito provavelmente por serem de caráter mais amplo.

São cinco os modelos de democracia identificados pelas autoras, brevemente descritos e comparados a seguir com os de Toti (2011):

i) modelo liberal clássico: O modelo liberal clássico se baseia na crença de que a elaboração de direitos universais aplicáveis a todos os cidadãos garantiria uma igualdade na vida social. Este modelo se aproxima muito da “cidadania e teoria liberal”, de Toti (2011).

ii) modelo republicano: Este modelo reforça os aspectos jurídicos implícitos no liberalismo clássico, reafirmando o pertencimento dos indivíduos numa comunidade e os incentivando a participar ativamente no processo político. Este modelo, contudo, acaba por subestimar o papel das diferenças e contradições na construção de consensos e não leva em conta as assimetrias de poder entre os sujeitos e suas respectivas desigualdades sociais. Este modelo, assim, se aproxima em alguma medida da "cidadania e republicanismo cívico” de Toti (2011), embora uma relação com a “cidadania e republicanismo participativo” também pode ser cogitada, apesar de mais distante.

iii) modelo procedimentalista: O modelo procedimentalista, desenvolvido por Jürgen Habermas, se situa entre o modelo liberal clássico e o republicano, buscando garantir os direitos individuais mas sem desconsiderar o contexto cultural específico. Há um deslocamento, neste modelo, da ideia de universalização da ciência para a universalização do ato comunicativo. Este modelo se aproxima da “cidadania e republicanismo participativo" de Toti (2011), ambos influenciados por Habermas.

iv) modelo liberal multicultural: Este modelo está ancorado no liberalismo, mas dando ênfase na concessão de direitos individuais a grupos com determinadas características. Há uma preocupação, neste modelo, na possibilidade de grupos dominantes requererem direitos diferenciados, o que iria contra seus ideais de uma sociedade mais igualitária. Este modelo possui várias semelhanças com a “cidadania na pós-modernidade” de Toti (2011), tanto por 
destacar os aspectos do pós-modernismo e do multiculturalismo, quanto por possuir aproximações possíveis com o liberalismo.

v) modelo participativo: O modelo participativo, elaborado por Boaventura de Souza Santos se contrapõe à simples realização do voto, assim como à crença de que a população possa ser considerada como um todo homogêneo. Esta incapacidade de homogeneização ocorre, segundo o autor, porque a sociedade atual é abissal, com divisões intrínsecas e intransponíveis, cujo rompimento só seria possível através da “ecologia dos saberes”, isto é, através da valorização de conhecimentos além do consolidado conhecimento científico.

É possível perceber, assim, que vários dos modelos de cidadania das autoras se aproximam das formas de cidadania identificadas por Toti (2011), havendo, inclusive, a recorrência das contribuições de Habermas, do liberalismo, do pós-modernismo e do republicanismo.

As categorias que não apresentaram convergências nítidas, isto é, “cidadania no comunitarismo" de Toti (2011) e o "modelo participativo” de Pinhão e Martins (2016), a nosso ver, não podem ser consideradas como divergências, mas sim como pontos de vistas diferentes originários de análises e recortes distintos, como construções complementares com um mesmo objetivo, isto é, compreender a cidadania.

As finalidades da educação identificadas por Pinhão (2014) são: educação para o bom convívio, relacionada com os modelos políticos "liberal clássico” e "republicanismo"; educação para o mercado, associada com o neoliberalismo; e educação para a transformação estrutural, ligada aos modelos “procedimentalista”, "liberal multicultural” e "participativo”.

Estas finalidades da educação apresentam pouca ou nenhuma convergência com as formas como os trabalhos de ensino de ciências incentivavam a cidadania identificadas por Toti (2011). A nosso ver, esta divergência pode ser parcialmente explicada porque este autor considera as finalidades da educação de maneira mais específica, e Pinhão e Martins (2016), de maneira mais geral.

O contexto em que as práticas em sala de aula voltadas à promoção da cidadania estão inseridas, portanto, apesar de bastante complexo e muito difícil de ser compreendido em sua totalidade, não pode ser simplesmente desconsiderado, já que limita ou facilita diferentes abordagens com este fim. É importante ressaltar, também, a impossibilidade de se pensar práticas voltadas à cidadania dentro de um contexto ditatorial ou repressivo, onde inexistam liberdades individuais e coletivas para agir politicamente. 


\subsection{Aspectos específicos das Ciências e sua dinâmica}

Outra dimensão importante para se compreender a produção acadêmica destinada ao incentivo da cidadania é aquela que compreende aspectos específicos das Ciências e sua dinâmica. Mesmo que estes aspectos se distanciem da cidadania em si, são capazes de influenciar diretamente práticas de ensino de ciências em sala de aula com este fim.

Visões de Ciência mais próximas da realidade, incluindo seu processo de construção e desenvolvimento, a confiabilidade que lhe é conferida por parte das pessoas não ligadas à pesquisa científica e sua relação com a sociedade, tanto no que diz respeito ao financiamento que aquela recebe, quanto a dependência e a influência recíprocas, podem comparecer ou não em propostas didáticas e afetar seus rumos e encaminhamentos.

Santos e Mortimer (2001², apud TOTI, PIERSON e SILVA, 2009, p.5), destacam a importância de se desenvolver a tomada de decisões na formação da cidadania, não sendo suficiente, para isso, transmitir informações sobre questões de Ciência e Tecnologia ou ensinar passos para que os estudantes tomem decisões. É necessário, na educação para a cidadania, ultrapassar o ensino conceitual, chegando a uma educação comprometida com a ação social responsável. Esses autores, porém, alertam para o risco da adoção de visões deformadas de ciência no seu ensino implicar atividades contrárias aos valores democráticos.

Vários autores (PRAIA, GIL-PÉREZ e VILCHES, 2007³; GIL-PÉREZ e VILCHES, 2005 e CACHAPUZ et al., 2005 apud TOTI, PIERSON e SILVA, 2009) defendem que "a formação científica para a cidadania se justifica pela necessidade de permitir a participação dos indivíduos em decisões de natureza tecnocientífica.” (TOTI, PIERSON e SILVA, 2009, p. 8-9) Eles ressaltam, também, que os conhecimentos específicos dos especialistas não garantem a adoção de decisões adequadas, podendo os "não especialistas" acrescentarem contribuições mais significativas ao apresentarem perspectivas e interesses mais amplos, sendo necessário, para isso, um mínimo de conhecimentos científicos específicos sobre a problemática.

2 SANTOS, W. L. P.; MORTIMER, E. F. Tomada de decisão para a ação social responsável no Ensino de Ciências. Ciência \& Educação. Bauru: UNESP, v.7, n.1, p.95-111, 2001.

3 PRAIA, J.; GIL-PÉREZ, D.; VILCHES, A. O papel da natureza da ciência na educação para a cidadania. Ciência e Educação. Bauru, v.13, n.2, p. 141-156, 2007.

4 GIL-PÉREZ, D; VILCHES, A. Contribution of science and technological education to citizens' culture. Canadian Journal of Science, Mathematics \&Technology Education, Toronto, v. 5, n. 2, p. 85-95, 2005. 
Entre os aspectos específicos das Ciências e sua dinâmica, temos alguns conceitos que dizem respeito a compreensões superficiais de Ciências e, quando considerados, podem implicar propostas destinadas à promoção da cidadania bastante distintas. Estes conceitos são a tecnocracia, a perspectiva salvacionista da Ciência-Tecnologia (CT) e o determinismo tecnológico.

No primeiro desses conceitos, a tecnocracia, apresentada por vários autores (AULER, 2003; AULER e DELIZOICOV, 2001; CASSAB, 2008; SANTOS E AULER, 2015; PINHÃO E MARTINS, 2016), temos, para cada problema ou questão que envolva debates e escolhas, apenas uma solução ótima. Se na democracia temos a possibilidade de consulta popular sobre uma temática, na tecnocracia não há essa necessidade, pois apenas o conhecimento científico possuído pelos cientistas é necessário e suficiente para a tomada de qualquer decisão, sendo este conhecimento superior a qualquer outro.

Há, dentro da tecnocracia, um determinismo tecnológico que acaba por excluir a possibilidade da democracia e da cidadania. Se a cidadania é algo almejado, seria papel da educação incentivar o cidadão comum a agir, tomar decisões e intervir na pauta de trabalho dos especialistas, rompendo com a tecnocracia. (CASSAB, 2008)

No segundo conceito, isto é, na perspectiva salvacionista da Ciência-Tecnologia (CT) (AULER e DELIZOICOV, 2001), temos que a Ciência e a Tecnologia se desenvolvem de maneira linear, fazendo com que todos os problemas hoje existentes em nossa sociedade sejam solucionáveis pela CT em algum momento do presente ou do futuro, sendo atingido, assim, um estado de bem-estar social. Está implícita a essa perspectiva que a CT conduzem, necessariamente, ao progresso, sendo desenvolvidas apenas com o intuito de solucionar os problemas da humanidade. (SACHS, 1996)

O terceiro conceito, denominado determinismo tecnológico, implica que a mudança tecnológica é a causa das mudanças sociais, com a tecnologia definindo os limites do que a sociedade pode fazer, assim como a tecnologia se comportando de maneira autônoma e independente das influências sociais. (AULER e DELIZOICOV, 2001)

Estes aspectos, por dizerem respeito a concepções de Ciências mais próximas da realidade, levando em conta algumas das suas relações com a sociedade, têm grande potencialidade de influenciarem atividades didáticas de ensino de ciências voltadas à cidadania. 


\subsection{Abordagens para a Cidadania na Pesquisa em Ensino de Ciências}

Além das reflexões anteriormente citadas, alguns textos da área de Pesquisa em Ensino de Ciências voltada para o exercício da cidadania fazem referência a abordagens específicas, que recebem denominações distintas e aparecem com recorrência.

Tenreiro-Vieira e Vieira (2005), ao darem atenção à relação entre cidadania e economia, mencionam que a literacia científica pode ser um componente importante no mundo do trabalho e no crescimento econômico, possuindo, assim, um papel na cidadania efetiva e responsável.

Para Chassot (20005 ; $2003^{6}$ apud CASSAB, 2008), a alfabetização científica incentiva não apenas a socialização de um conjunto de conhecimentos capazes de proporcionar uma leitura crítica de mundo, mas, principalmente, a promoção da capacidade de transformar o mundo.

Sasseron e Carvalho (2011), ao estudarem a literatura estrangeira relacionada à Didática das Ciências, percebem uma variação no uso do termo que define o ensino de Ciências preocupado com a formação cidadã dos alunos para ação e atuação em sociedade. Segundo as autoras, entre os diferentes termos utilizados, que variam de acordo com o país e a língua de origem, aparecem “Alfabetização Científica”, “Enculturação Científica” e "Letramento Científico".

Auler et al. (2005) destacam a potencialidade do desenvolvimento de atitudes de tomada de decisão por parte dos alunos, a partir de abordagens do denominado movimento Ciência-Tecnologia-Sociedade (CTS). Os autores, em seguida, ressaltam a aproximação desse movimento com o pensamento do educador Paulo Freire, no que diz respeito à busca de participação e democratização nas decisões em temas sociais que envolvem CiênciaTecnologia.

Teixeira (2003), ao fazer uma comparação entre a Pedagogia Histórico-Crítica e o movimento CTS, afirma que há mais radicalidade naquela, pois ela defende que a "cidadania está diretamente vinculada a um movimento que busca sérias transformações na sociedade injusta e excludente que hoje se apresenta.” (TEIXEIRA, 2003, p. 184)

5 CHASSOT, A. Alfabetização científica: Novas alternativas para novas exigências. Educação Em Foco, Juíz de Fora, v. 5, n. 1, p. 29-42, 2000.

6 CHASSOT, A. Alfabetização científica: uma possibilidade para a inclusão social. Revista Brasileira de Educação, n. 22, p. 89-100, jan/abr. 2003. 
Segundo Toti, Pierson e Silva (2009, p. 2):

O núcleo central da educação com enfoque CTS está orientado para o desenvolvimento de atividades educativas com ênfase na tomada de decisões, sobretudo aquelas relacionadas com aspectos sociais que têm como parâmetro importante a Ciência e a Tecnologia. Segundo Santos e Mortimer (2002), essa proposição dos currículos com ênfase na abordagem CTS baseia-se na tentativa de disponibilizar aos estudantes as representações que lhes possibilitem agir, tomar decisões e compreender o que está em jogo no discurso dos especialistas, sendo esta uma prerrogativa do exercício da cidadania. Nesse sentido, o enfoque CTS contribui para a superação do modelo vigente em amplos setores da sociedade de decisões tecnocráticas. Além disso, visa à superação da perspectiva salvacionista/redentora atribuída à Ciência e à Tecnologia.

Carvalho et al. (2015) discutem a criação de projetos de lei (PLs) e de propostas de emenda à constituição (PECs) como importantes ferramentas para incentivar a cidadania e a participação social dos estudantes, rompendo com a concepção de cidadania existente apenas durante as eleições. Para esses mesmos autores, também, as Questões Sociocientíficas (QSC), por analisarem mais profundamente os impactos sociais do desenvolvimento científico e tecnológico, possuem muitos elementos para o debate sobre legislação e cidadania.

Para Ratcliffe e Grace (2003 ${ }^{7}$ apud PÉREZ, 2012, p. 60):

as QSC abrangem a formação de opiniões e a escolha de juízos pessoais e sociais, implicam valores e aspectos éticos e relacionam-se com problemas sociais de ordem local, nacional e global.

As denominações aqui mencionadas, isto é, Alfabetização Científica (AC), Literacia Científica, Enculturação Científica, Ciência-Tecnologia-Sociedade (CTS) e Questões Sociocientíficas (QSC), aparecem de maneira recorrente dentro da literatura de Pesquisa em Ensino de Ciências voltada para o exercício da cidadania.

Estas denominações representam um recorte de algumas das abordagens em ensino de ciências voltadas à promoção da cidadania, apresentando, contudo, definições distintas, bem como várias peculiaridades não evidentes em um primeiro momento.

Os capítulos subsequentes buscam uma aproximação na direção de compreender estas peculiaridades, se valendo, para isso, tanto de uma aproximação com artigos e teses de cunho teórico acerca das temáticas de interesse, quanto de uma aproximação quantitativa e qualitativa de trabalhos recentes que colocam em prática as discussões teóricas.

7 RATCLIFFE, M.; GRACE M. Science Education for Citizenship: Teaching Socio-Scientific Issues. Maidenhead: Open University Press, 2003. 
A compreensão das peculiaridades dessas abordagens é importante para que seja possível aproximá-las de uma prática em sala de aula voltada à promoção da cidadania consciente das muitas possibilidades e compromissada com a realidade da sala de aula. 


\section{Capítulo 2 - Diferentes ênfases para a cidadania}

As denominações apontadas na última seção do capítulo anterior, quais sejam Alfabetização Científica (AC), Literacia Científica, Enculturação Científica, CiênciaTecnologia-Sociedade (CTS) e Questões Sociocientíficas (QSC), são algumas das que estão bastante presentes na Pesquisa em Ensino de Ciências com foco na promoção de uma postura cidadã. Essas denominações, contudo, aparecem seguidas de várias definições dentro da produção acadêmica da área, nem sempre em sintonia e nem sempre conciliáveis a primeira vista.

Na tentativa de compreender algumas das características destas denominações, bem como suas várias definições, apresentamos, a seguir, uma sistematização das definições encontradas em artigos, teses e dissertações da área. Esta sistematização inclui, sempre que possível, reflexões e pressupostos apontados por pesquisadores de referência, assim como as eventuais relações de aproximação que estabelecem entre si e alguns dos aspectos específicos da ciência e sua dinâmica, discutidos no capítulo anterior.

As abordagens aqui diferenciadas serão Alfabetização Científica (AC), CiênciaTecnologia-Sociedade (CTS), Questões Sociocientíficas (QSC), Questões Controversas e Questões Socioambientais. Elas representam um recorte do amplo conjunto de abordagens presente na Pesquisa em Ensino de Ciências voltada à promoção da cidadania.

\subsection{Alfabetização Científica}

A denominação Alfabetização Científica (AC) inclui a área dentro do Ensino de Ciências que se propõe a alfabetizar cientificamente os alunos. Essa alfabetização, contudo, pode ocorrer segundo diferentes perspectivas, defendidas por diferentes pesquisadores.

As diferenças de entendimento aparecem já durante a tradução, pois, como apontam Sasseron e Carvalho (2011), a tradução de textos em inglês e em espanhol trazem a expressão “Alfabetização Científica” e "Letramento Científico” e as traduções de textos em francês trazem os termos “cultura científica” e "Enculturação Científica”. 
Essas diferentes denominações carregam consigo concepções distintas, com a expressão “Letramento Científico” estando ligada ao ato de aprender ou ensinar a ler e a escrever, associada ao seu uso em um grupo social.

O termo “Alfabetização Científica”, por outro lado, pode ser usado com o significado de alfabetização proposta por Paulo Freire, considerando a leitura da palavra como relacionada à leitura de mundo, como capaz de construir uma consciência crítica (SASSERON e CARVALHO, 2011). A AC, daria, assim, elementos capazes de proporcionar uma leitura de mundo diferente aos alunos.

A denominação “Enculturação Científica”, por outro lado, destaca o caráter cultural da ciência, incentivando os alunos a compartilharem dela, de suas noções, conceitos e ideias (SASSERON e CARVALHO, 2011). A ciência, quando vista como cultura, tem a sua face humana destacada, sendo mostrada como dependente das pessoas que a constroem e da sociedade em que essas pessoas estão inseridas.

As autoras afirmam que, embora existam muitas concepções de Alfabetização Científica encontradas na literatura, originárias ou não de diferentes traduções, há convergências que permitem agrupar as concepções em três eixos estruturantes. Esses eixos são a compreensão básica de termos, conhecimentos e conceitos científicos fundamentais; a compreensão da natureza das ciências e dos fatores éticos e políticos que circundam sua prática; e o entendimento das relações existentes entre ciência, tecnologia, sociedade e meio ambiente. (SASSERON e CARVALHO, 2011)

O primeiro desses eixos inclui as atividades que buscam promover a leitura de textos, tabelas e gráficos, principalmente com o intuito de compreender as informações presentes em reportagens jornalísticas e nos materiais de divulgação científica.

O segundo eixo está bastante associado ao fazer científico, incluindo a construção do raciocínio científico, com a elaboração de hipóteses e modelos, a realização de experiências e a inclusão de fatores éticos que deveriam estar sempre presentes para guiar as pesquisas científicas e os interesses políticos.

O terceiro eixo, finalmente, está associado às relações entre ciência, tecnologia, sociedade e ambiente, almejando que a compreensão sobre conceitos próprios da ciência, como a leitura de tabelas e gráficos, assim como as grandezas envolvidas, sejam úteis para que os cidadãos emitam julgamentos sobre a escolha da matriz energética de um país ou as tentativas de se mitigar os impactos ambientais. Estudar as relações entre ciência, tecnologia, 
sociedade e ambiente é foco, também, da segunda abordagem detalhada a seguir, a CTS(A). Há, assim, pelo menos no que diz respeito a esse eixo de AC, uma aproximação com a CTS(A).

Estes eixos são compatíveis com categorias criadas por outros autores. Santos (2007), por exemplo, afirma que a educação científica na perspectiva do letramento como prática social deve incluir três aspectos, a saber, a natureza da ciência, que a compreende como construção, como provisória e como situada em um contexto histórico; a linguagem científica, que inclui a leitura de gráficos, tabelas e esquemas; e os aspectos socieocientíficos.

Os vários aspectos sociocientíficos, por sua vez, podem ser agrupados, conforme seus objetivos, em cinco categorias (SANTOS, 2007, p. 12):

1) relevância - encorajar os alunos a relacionar suas experiências escolares em ciências com problemas de seu cotidiano e desenvolver responsabilidade social; 2) motivação - despertar maior interesse dos alunos pelo estudo de ciências; 3) comunicação e argumentação - ajudar os alunos a verbalizar, ouvir e argumentar; 4) análise - ajudar os alunos a desenvolver raciocínio com maior exigência cognitiva; 5) compreensão - auxiliar na aprendizagem de conceitos científicos e de aspectos relativos à natureza da ciência (Ratcliffe, 1998) ${ }^{8}$.

Shen (1975 ${ }^{9}$ apud CUNHA, 2017), por sua vez, resgata três categorias de scientific literacy que não são excludentes, mas distintas de acordo com o objetivo e a audiência. A primeira delas é de ordem prática, envolvendo o conhecimento científico; a segunda, denominada de cívica, abrange o conhecimento necessário para compreender os problemas sociais ligados à CT; e a terceira, que recebe o nome de cultural, compreende o desejo de conhecer a ciência enquanto maior realização humana.

Laugksch (2000), após identificar várias concepções de Alfabetização Científica na literatura, diferencia três concepções de ser alfabetizado, a saber, alfabetizado como capaz de ler e interpretar; alfabetizado como competente; e alfabetizado como possuidor de um mínimo nível de conhecimento necessário para atuar em papéis da sociedade ${ }^{10}$, em nível decrescente de alfabetismo.

8 RATCLIFFE, M. Discussing socio-scientific issues in science lessons: pupils' actions and the teacher's role. School Science Review, v. 79, n. 288, p. 55-59, 1998.

9 Shen, B. S. P. Science literacy. American Scientist, Durham (Estados Unidos): Sigma Xi Scientific Research Society, v. 63, n. 3, p. 265-268, May/June 1975. Disponível em: <http://www.jstor.org/stable/pdfplus/27845461.pdf>. Acesso em: 28 set. 2016.

10 As categorias construídas por Laugksch têm as denominações "literate as learned"; "literate as competent" e "literate as able to function minimally in society". As traduções aqui apresentadas são de autoria própria. 
Essas diferentes concepções, defendida por vários autores, porém, dialogam entre si. Segundo Moebus e Martins (2013, p. 6):

\begin{abstract}
Apesar de todos (os artigos) estabelecerem a variedade de definições existentes na literatura, todos tendem a se filiar a uma concepção de que promover AC nas aulas de Ciências significa permitir que os alunos apreciem seu mundo e sua cultura de uma perspectiva científica e que permitam responder mais significantemente e criticamente a questões baseadas em ciência que afetam indivíduos, comunidades e sociedade.
\end{abstract}

Vale a pena destacar que, se existe a compreensão de indivíduos cientificamente alfabetizados ou cientificamente letrados, pode-se conjecturar a existência de indivíduos cientificamente iletrados, ou analfabetos científicos. Essa é a problematização trazida por Cunha (2017) a partir da afirmação de Chassot (2003 ${ }^{11}$, p. 91, apud CUNHA, 2017, p. 177), de que "ser alfabetizado cientificamente é saber ler a linguagem em que está escrita a natureza. É um analfabeto científico aquele incapaz de uma leitura do universo”.

Cunha (2017) ressalta que a definição de Chassot exclui qualquer leitura não científica do universo, assim como conhecimentos historicamente construídos por grupos sociais que não a comunidade científica. Isto pode se configurar como uma violência, implicando, até mesmo, em uma resistência do estudante ao ensino, à alfabetização, já que ele tem consciência do desprezo que seu educador nutre pela sua cultura e pela sua leitura de mundo.

Além das diferentes concepções de Alfabetização Científica e do possível choque entre culturas, temos, também, a dificuldade em se averiguar o quanto aquela se concretizou. Fourez (1994 ${ }^{12}$ apud SASSERON e CARVALHO, 2011) apresenta 14 habilidades que considera necessárias para classificar uma pessoa como alfabetizada cientificamente.

Um indivíduo alfabetizado cientificamente deveria, entre outras tarefas, compreender que a sociedade exerce controle sobre as ciências e tecnologias, bem como que as ciências e as tecnologias refletem a sociedade. Essas habilidades poderiam, assim, ser tanto elementos capazes de delinear o ensino de propostas de AC, quanto eixos de avaliação da AC.

Ainda sobre a avaliação de aprendizado de um estudante sobre a AC, temos tanto o trabalho de Sasseron (2008 ${ }^{13}$, apud PIZARRO e LOPES Jr., 2015), que destaca indicadores de um indivíduo alfabetizado cientificamente, quanto o trabalho de Pizarro e Lopes Jr. (2015),

11 CHASSOT, A. Alfabetização científica: uma possibilidade para a inclusão social. Revista Brasileira de Educação, n. 22, p. 89-100, jan/abr. 2003.

12 FOUREZ, G. Alphabétisation Scientifique et Technique - Essai sur les finalités de l'enseignement des sciences, Bruxelas: DeBoeck-Wesmael, 1994.

13 SASSERON, L. H. Alfabetização Científica no Ensino Fundamental: Estrutura e Indicadores deste processo em sala de aula. São Paulo, 2008, 265f. Tese - Doutorado em Educação, Faculdade de Educação, Universidade de São Paulo, São Paulo, 2008. 
que, a partir dos indicadores da autora, aponta indicadores que se dividem em três categorias, a saber: a) indicadores presentes nas habilidades dos alunos, tanto de leitura, quanto de escrita; b) na argumentação deles; e, finalmente, c) nas implicações sociais de seu aprendizado.

Esses indicadores destacam, assim, a importância de se valorizar a argumentação dos estudantes, principalmente na forma oral, tanto devido ao fato dos estudantes dentro do sistema tradicional de ensino não serem incentivados a se expressar, quanto devido ao fato dos estudantes nos níveis iniciais de escolarização não estarem completamente alfabetizados na forma escrita. (PIZARRO e LOPES Jr., 2015)

Vale a pena mencionar, também, que comparecem nas AC os aspectos sobre as compreensões de Ciência mais próximas da realidade apontados no capítulo anterior. A adoção dos conceitos tecnocracia, perspectiva salvacionista da Ciência-Tecnologia (CT) e determinismo tecnológico, por exemplo, pode influenciar profundamente a abordagem seguida.

\subsection{Ciência-Tecnologia-Sociedade (CTS)}

Tal como a Alfabetização Científica, a denominação Ciência-Tecnologia-Sociedade aglutina um conjunto de abordagens dentro da área de Pesquisa em Ensino de Ciências voltada à promoção da cidadania, também contando com muitas compreensões, modelos de sociedade e aspectos privilegiados.

Além da ocorrência daquela denominação, também aparece de maneira recorrente a expressão Ciência-Tecnologia-Sociedade-Ambiente (CTSA), com a adição da palavra “Ambiente”. Há, no conjunto de abordagens que a usa, uma tentativa de destacar o papel do Meio Ambiente, ressaltando conceitos e conteúdos mais estreitamente ligados à Biologia e à Química, abrindo novas possibilidades de caminhos metodológicos.

Ribeiro, Santos e Genovese (2015), contudo, se usam de conceitos cunhados por Pierre Bourdieu, para afirmar que o denominado movimento CTS se constitui como um campo de disputa, sendo esta disputa, contudo, velada. São várias as formas de tornar esta disputa não aparente, sendo uma das principais delas a unificação de correntes de pensamentos distintas, 
que surgiram em diferentes momentos históricos, dentro de apenas uma denominação. A este respeito, Ribeiro, Santos e Genovese (2015, p. 4), afirmam:

Esse trabalho simbólico de unificação visa não somente constituir o conhecimento e o reconhecimento entre os agentes, sua mobilização em torno de determinados objetos, inclinando-os ao investimento e, assim, estabelecer a construção de uma identidade coletiva; mas, também, dissimulam a construção de falsos consensos sobre a estrutura.

Reunir várias abordagens em apenas uma denominação seria, assim, uma tentativa de unificação de diferentes modos de pensamento, incentivando os pesquisadores da área a construírem objetivos comuns e trabalharem numa mesma direção, dissimulando a construção de falsos consensos e o campo de disputa em que eles estão inseridos.

O uso de denominações para dissimular campos de disputa ocorre tanto com o uso da expressão CTS, quanto CTSA, mesmo que elas tenham sido cunhadas e adotadas em diferentes épocas e de maneiras distintas.

Diante dessas reflexões, fica claro que não seria adequado se utilizar de nenhuma denominação para se referir a esta área. A denominação CTS(A), usada por autores como Aguiar-Santos, Vilches e Brito (2016), porém, explicita tanto a denominação CTS, quanto a CTSA, de maneira que fiquem visíveis pelo menos duas abordagens bastante proeminentes na área, bem como carregam consigo uma pequena imagem do campo de disputa que a permeia. O uso da expressão CTS(A) se justifica, também, pelo fato de, mesmo com a existência de várias abordagens na área, existirem pressupostos e objetivos comuns entre os trabalhos.

A respeito dos pressupostos que guiam grande parte das pesquisas da área, Aikenhead (1994, p. 49) afirma:

Espera-se que a CTS preencha um vazio no currículo tradicional - a responsabilidade social na tomada de decisões coletivas em questões relacionados à Ciência e à Tecnologia. Tais questões necessitam de uma relação harmoniosa entre uma elite científico-tecnológica e cidadãos formados e atentos. Juntos, ambos grupos precisarão realizar decisões complexas que envolvem "a aplicação de conhecimento científico, intimidade com a tecnologia, reconhecimento social e compaixão humana” (Kranzberg, 1991, p. 238) $)^{14}$. (tradução nossa) ${ }^{15}$

14 KRANZBERG, M. Science-tecnology-society: It's as simple as XYZ! Theory in Practice, v. 30, n. 4, p. 234-241, 1991.

15 O trecho original é: STS science is also expected to fill a critical void in the traditional curriculum - the social responsibility in collective decision making on issues related to science and technology. Such issues require a harmonious mix of a scientific-technical elite with an informed attentive citizenry. Together both groups will need to make complex decisions that involve "the application of scientific knowledge, technological expertise, social understanding, and humane compassion” (Kranzberg, 1991, p. 238) 
O autor afirma, ainda, que o objetivo da responsabilidade social na tomada de decisões coletivas encaminha para vários objetivos relacionados, como o empoderamento individual, capacidades intelectuais como pensamento crítico, argumentação lógica, resolução de problemas de forma criativa, tomada de decisão, cidadania nacional e global, democracia e administração, ação socialmente responsável de indivíduos e mão de obra hábil para empresas e indústrias. (AIKENHEAD, 1994)

A tomada de decisões é destacada como central nas abordagens CTS(A), tanto pelo mesmo autor (AIKENHEAD, 1994), sendo parte importante de uma metodologia específica, quanto em outros trabalhos (SANTOS e MORTIMER, 2002; CARVALHO, MOREIRA e AGUIAR Jr, 2015). Esta tomada de decisões, contudo, não pode ser entendida como simples escolha, mas sim ter como base os conhecimentos adquiridos, tanto de Ciências, quanto das outras temáticas envolvidas no decorrer do processo educacional.

Outro pressuposto que guia boa parte dos trabalhos com abordagem CTS(A), sendo um dos principais fatores para o seu surgimento, são as críticas ao modo de produção capitalista e seus principais desdobramentos, como o consumo desenfreado, a obsolescência planejada dos bens de consumo e a busca incessante por lucro, o que leva a um desrespeito estrutural com o meio ambiente (AULER et al., 2005; CARDOSO, ABERU e STRIEDER, 2016; ROSO e AULER, 2016). Seria função da CTS(A), assim, elaborar propostas que incentivem o combate a esses problemas que assolam a humanidade e o ambiente, mesmo que de diferentes maneiras.

Apesar de suas semelhanças, são várias as diferenças presentes dentro das abordagens CTS(A), que podem ser identificadas de diversas maneiras, como, por exemplo, analisando a centralidade que assumem as discussões CTS e as linhas de pensamento existentes geograficamente neste movimento.

A respeito da centralidade das discussões CTS nas abordagens, temos, por exemplo, os oito níveis desenvolvidos por Aikenhead (1994), que buscam medir a proporção entre a presença de “conteúdos CTS” e os “conteúdos puros de ciência”. No primeiro desses níveis, em um extremo, temos abordagens tradicionais de ciência com apenas uma breve menção aos conteúdos CTS. No último desses níveis, no outro extremo, temos o estudo de um tema tecnológico ou social que assume caráter central, de maneira que os conteúdos de ciências propriamente ditos são apenas mencionados. Fazem parte destes níveis outros seis, quantificando proporções intermediárias entre esses dois tipos de conteúdos. 
Uma outra forma de compreender as diferenças das abordagens CTS é a criada por Moniz dos Santos (2001 ${ }^{16}$ apud STRIEDER, 2012). Segundo aquela autora, estas diferenças estão associadas ao valor que é atribuído à ciência, à tecnologia e à sociedade. As diferentes abordagens, assim, podem ser classificadas entre as que continuam a privilegiar a ciência (Cts), as que privilegiam a tecnologia (cTs) e as que privilegiam a sociedade (ctS).

Palacios, Otero e Garcia (1996 ${ }^{17}$ apud PINHEIRO, SILVEIRA e BAZZO, 2009), diferenciam as abordagens CTS em três grupos, de acordo com a forma com que colocam em prática as discussões teóricas: enxerto CTS; ciência e tecnologia por meio de CTS; e CTS puro. No primeiro desses grupos, há a introdução de temas CTS nas disciplinas de ciências para abrir discussões do que seria ciência e tecnologia; no segundo, estrutura-se o conteúdo científico por meio do CTS, tanto abordando apenas uma disciplina, quanto mais de uma; no terceiro, ensina-se ciência, tecnologia e sociedade por intermédio da CTS, possuindo o conteúdo científico caráter secundário.

As diferentes abordagens que se usam da expressão CTS(A) podem ser analisadas, também, considerando as linhas de pensamento que adotam, seguidas em regiões específicas do planeta Terra. Essas linhas são a europeia, a americana e o Pensamento Latino Americano em CTS (PLACTS) (STRIEDER, 2012, p. 24-26). Apesar de Garcia, Cerezo e Luján (1996 ${ }^{18}$ apud STRIEDER, 2012, p. 24-25) defenderem que esta divisão esteja superada, sendo importante apenas no início das discussões, julgamos que ela seja uma forma bastante útil de se compreender os vários encaminhamentos das abordagens CTS(A).

A linha europeia, também chamada de acadêmica, devido a sua origem em âmbito institucional, principalmente com cientistas, engenheiros, sociólogos e humanistas, possuía como intenção investigar as influências da sociedade sobre o desenvolvimento científico e tecnológico.

A linha americana, também denominada de social, já que foi bastante ligada a movimentos sociais, como os promovidos pelos grupos pacifistas, ativistas dos direitos humanos, entre outros, tinha como preocupação as consequências sociais e ambientais dos produtos tecnológicos.

16 SANTOS, M. E. V. M. dos. A cidadania na voz dos manuais escolares. Lisboa: Livros Horizonte, 2001.

17 PALACIOS, F. A.; OTERO, G. F. P., GARCIA, T. R. Ciencia, tecnología y sociedad, manual de educación secundária, Madrid, Ediciones Laberinto, 1996.

18 GARCÍA, M. I. G.; CEREZO, J. A. L.; LUJÁN, J. L. Ciência, tecnologia y sociedad. Uma introducción al estúdio social de la ciência y la tecnología. Madrid: Tecnos, 1996. 
Finalmente, o Pensamento Latino Americano em CTS (PLACTS), denominação proposta por Dagnino, Thomas e Davyt (2003 ${ }^{19}$ apud STRIEDER, 2012, p. 25-26), é o resultado de reflexões críticas sobre o modelo linear de desenvolvimento e de uma intenção de mudança social para os países latino-americanos. Essa linha de pensamento se caracterizaria não apenas por questionar as consequências sociais do desenvolvimento CT ou seus antecedentes, mas, principalmente, por criticar o modelo de Política CientíficoTecnológica adotada nos países latino-americanos, baseada em países de primeiro mundo e indo contra suas necessidades regionais.

Marcam presença aqui, portanto, em diferentes níveis, os aspectos apresentados no capítulo anterior a respeito das compreensões de Ciências mais próximas da realidade, assim como os conceitos de tecnocracia, perspectiva salvacionista da Ciência-Tecnologia e determinismo tecnológico, que podem influenciar as abordagens CTS(A).

As convergências dentro das abordagens CTS(A) aparecem, também, do ponto de vista prático, mais diretamente relacionado à dinâmica da sala de aula. Dentre essas convergências, temos o uso de temáticas específicas, frequentemente ligadas ao cotidiano dos alunos. Aparecem, assim, a temática dos transportes como motivadora para incluir os conceitos tradicionais de termodinâmica (CARVALHO, MOREIRA e AGUIAR Jr, 2015); o transporte particular e o coletivo para os conceitos de conservação e transformação de energia (AULER et al., 2005); e a construção de uma rádio comunitária para trabalhar os conceitos de eletromagnetismo (BONETTI, 2016).

Essas temáticas, porém, não aparecem como simples motivação, sendo, de fato, elementos de caráter central nas discussões. No primeiro trabalho, por exemplo, é usado o conceito de eficiência energética dos motores a combustão para se questionar as fontes de energia dos meios de transporte e, no segundo, o ponto de partida da proposta é "a privatização de Empresas Públicas e posterior concessão, de recursos obtidos, de uma série de vantagens sob a forma de incentivos e isenção fiscal à empresa General Motors (GM).” (AULER et al., 2005, p.3)

Outro aspecto de convergência das abordagens CTS(A) é a tentativa de motivação de estudantes dentro de ambientes com grande dificuldade de aprendizado, como a Educação de

19 DAGNINO, R.; THOMAS, H.; DAVYT, A. El Pensamiento em Ciencia, Tecnologíay Sociedad em Latinoamérica: uma interpretación política de su trayectoria. In: DAGNINO, R.; THOMAS, H. Ciência, Tecnologia e Sociedade: uma reflexão latino-americana. Taubaté: Cabral Editora e Livraria Universitária, 2003. 
Jovens e Adultos, a educação em escolas periféricas, a educação rural (BONETTI, 2016) e a educação dentro do espaço prisional (MELO, SOUZA e CONTENTE, 2015).

\subsection{Questões Sociocientíficas (QSC)}

A denominação Questões Sociocientíficas inclui um conjunto de abordagens que concordam em ter como ponto de partida temas presentes no cotidiano dos alunos, principalmente nas matérias jornalísticas, dando foco à dimensão ambiental, à saúde pública e à ética.

Aparecem, neste tipo de abordagem, de maneira recorrente, temas como o consumo e a produção de alimentos transgênicos, a realização do aborto, a anorexia, a automedicação, a disposição do lixo e o consumo de drogas por adolescentes. (PÉREZ, 2012)

Dada a íntima relação destes temas com as QSC, fica visível sua potencialidade com a Biologia e com a Química, não necessariamente havendo uma restrição às abordagens disciplinares. Carnio e Carvalho (2015), a este respeito, criticam a disciplinarização do currículo de ciências, ressaltando a importância das QSC neste processo.

Para a construção desta crítica, esses autores se usam da dialética e dos conceitos de identidade e não identidade apresentados por Theodor Adorno para afirmar que os conceitos são uma tentativa totalizante e prepotente de esgotar a realidade e os objetos, sendo rígidos e absolutos. Seria papel da crítica, assim, questionar a rigidez e prepotência dos conceitos, para que eles se aproximem da realidade. As QSC, seriam importantes, pois, dentro deste cenário, carregam uma parcela de criticidade e de combate à consolidação de disciplinas e conteúdos. (CARNIO e CARVALHO, 2015)

A respeito das contribuições e dificuldades enfrentadas por professores na implementação de abordagens envolvendo QSC, Pérez e Carvalho (2012) apontam a disciplinaridade existente nas escolas e a desunião dos professores de diversas disciplinas como entraves a uma maior adoção desta abordagem.

As QSC incluem, com frequência, debates sobre questões éticas e morais, como apontam Zeidler e Keefer (2003). Essas questões aparecem, na maioria das vezes, durante uma tomada de decisão, em que atuam princípios com um caráter de universalidade, como vida, consciência, leis, autoridade, contrato e punições. A ética e a moral têm grande 
potencialidade de incentivar discussões que promovam o exercício da argumentação dos alunos.

Sadler e Zeidler (2004, p.7) ressaltam, contudo, que

Para que as considerações morais possam contribuir para a tomada de decisão em Questões Sociocientíficas, há a necessidade dos indivíduos considerarem estas como problemas morais. ${ }^{20}$ (tradução nossa)

Segundo estes autores, pelo menos três amplas filosofias morais podem teoricamente ser aplicadas à tomada de decisões em QSC: deontológica, consequencialismo e moralidade baseada em cuidado. ${ }^{21}$

A filosofia deontológica, relacionada à moralidade Kantiana, está baseada em regras morais e princípios, o que implica dizer que os dilemas morais possam ser solucionados através de normas prévias que os agentes da moral adotam.

A moralidade consequencialista, por outro lado, toma por base as consequências esperadas de uma decisão ou ação, julgando ser moralmente correta a opção que proporcionar maior quantidade de consequências positivas.

A moralidade baseada no cuidado, finalmente, rejeita a hipótese de que há uma fórmula única para se solucionar problemas morais. Há uma ligação, aqui, da moral com o contexto das situações individuais, comparecendo fatores como a emoção, a simpatia e a empatia na tomada de decisões.

Esses autores, buscando identificar quais fatores, além dos morais, influenciam a tomada de decisões em questões relacionadas à engenharia genética, entrevistam pessoas de ambos os sexos e com diferentes idades. Os resultados da análise das entrevistas apontam que são várias as influências na tomada de decisões, como a religião, experiência pessoal, opinião sujeita a mudança caso ocorresse com a pessoa entrevistada ou alguém de sua família, necessidade de maiores informações sobre engenharia genética para um posicionamento mais seguro e a influência final ser derivada da cultura popular, incluindo filmes e livros. (SADLER e ZEIDLER, 2004)

Dentre as possibilidades para colocar em prática abordagens que visem a discussão de QSC, bem como questões éticas e morais, Carvalho et al. (2015) defende o uso de projetos de

20 O trecho original é: "In order for moral considerations to contribute to socioscientific decisionmaking, the individual decision-makers must construe socioscientific issues as moral problems.” (tradução nossa)

21 Os nomes originais dessas três filosofias morais são, respectivamente, “deontology”, "consequentialism" e "care-based morality". As traduções aqui apresentadas são de autoria própria. 
lei (PLs) e as propostas de emenda à constituição (PECs) que podem ser utilizadas tanto em escala simulada, em sala de aula, quanto em escala formal, em câmaras de deputados e outras instâncias representativas.

Os autores relatam, neste trabalho, uma atividade em que os alunos deveriam assumir papéis de parlamentares e deveriam criar leis e políticas para lidar com as implicações do aquecimento global, devendo lidar, neste processo, com conflitos de interesses e a não neutralidade dos políticos e da ciência.

Tanto no contexto de juris simulados, quanto na discussão de PLs e PECs com base em QSC, é nítida a importância da argumentação dos estudantes. Sobre esta argumentação, Penha e Carvalho (2016) elaboram rubricas de análises para quantificar o desempenho dos alunos, considerando pontos como a qualidade dos argumentos usados e as oposições de ideias e pontos de vista que surgem durante o debate.

Vale a pena mencionar que, embora existam aproximações entre diversos autores da área a respeito do que seriam as Questões Sociocientíficas e quais seriam algumas de suas características, como exposto anteriormente, há algumas discordâncias importantes.

Para alguns autores (RAMSEY, $1993^{22}$ e RUBBA, $1991^{23}$ apud SANTOS e MORTIMER, 2009), as QSC são tidas como temas relativos às interações ciência-tecnologiasociedade (CTS). Wildson dos Santos e Eduardo Mortimer, em seus trabalhos, optam por traduzir socioscientific issues como aspectos sociocientíficos, pois eles entendem (SANTOS e MORTIMER, 2009, p. 2):

que questões ambientais, políticas, econômicas, éticas, sociais e culturais relativas à ciência e tecnologia são inerentes à atividade científica e que a sua abordagem no currículo pode ser feita: de forma temática, no sentido de tópico ou assunto amplo em que essas questões estão imbricadas (e.g. poluição ambiental, transgênicos, recursos energéticos etc.); ou de forma pontual, com exemplos de fatos e fenômenos do cotidiano relativos a conteúdos científicos que ilustram aplicações tecnológicas envolvendo esses aspectos; ou ainda por meio de questões dirigidas aos estudantes sobre esses aspectos.

22 Ramsey, J. The science education reform movement: implications for social responsibility. Science Education, v. 77, n. 2, p. 235-258, 1993.

23 Rubba, P. Integration STS into school science and teacher education: beyond awareness. Theory into Practice, v. 30, n. 4, p. 303-315, 1991. 


\title{
2.4 Questões Controversas
}

Ao analisar o que seriam os temas controversos e as abordagens ambientais críticas, Ribeiro e Kawamura (2014, p. 163) reconhecem "três âmbitos na articulação do papel do conhecimento científico e as questões envolvidas nas controvérsias”, o que implica

\begin{abstract}
diferentes níveis de abordagens críticas. Em um primeiro âmbito, as controvérsias buscam subsídios em resultados de pesquisas científicas, procurando localizar em seus elementos diferentes cenários ou impactos. É o caso, por exemplo, das controvérsias relacionadas ao aquecimento global ou às mudanças climáticas (Está mesmo ocorrendo um aumento da temperatura global?). Em um segundo âmbito, em geral associado à análise de riscos e benefícios, a natureza da controvérsia não é propriamente científica, mas envolve a discussão sobre a utilização de produtos e processos decorrentes das tecnologias contemporâneas (Você é contra ou a favor do uso de energia nuclear?). Finalmente, há ainda um terceiro âmbito em que as controvérsias são estudadas a partir de situações específicas, reais e concretas $(\mathrm{O}$ que dizer sobre a construção da Usina de Belo Monte?).
\end{abstract}

Temos, assim, pelo menos três abordagens distintas dentro do uso de Questões Controversas. Uma primeira é associada aos resultados das pesquisas científicas, sendo controversas e/ou complexas a determinação de grandezas, como a temperatura média da Terra, o que gera a impossibilidade de afirmar categoricamente a existência ou não do aquecimento global.

A segunda abordagem é associada à utilização dos produtos e processos originários da tecnologia, utilização que está associada ao cálculo dos seus riscos e benefícios, à possibilidade da tecnologia ser usada para o bem ou para o mal. Há, nesta abordagem, uma polarização que a aproxima de um maniqueísmo.

O terceiro tipo de abordagem, finalmente, reúne as controvérsias que têm como ponto de partida situações concretas e específicas, preferencialmente presentes no cotidiano, na forma de notícias jornalísticas e acontecimentos recentes. Como exemplos podemos citar as catástrofes de Mariana e Brumadinho.

Segundo as autoras, porém, as chamadas controvérsias científicas não são de fato controversas, pois, epistemologicamente falando, controvérsias se referem ao conceito científico, mas, neste tipo de abordagem, o que é levado em conta é a compreensão dos sistemas e ambientes da Terra, lembrando que não são levadas em conta na discussão de suas medidas e resultados o fato de se tratarem de sistemas complexos, isto é, compostos de inúmeras sub-unidades interagentes. (WATANABE-CARAMELLO, 2012, apud RIBEIRO e 
KAWAMURA, 2014) As controvérsias são interessantes, para as autoras, por não serem algo a ser superado, mas sim por serem capazes de explicitar contradições.

\subsection{Questões Socioambientais}

As várias abordagens que fazem referência à denominação Questões Socioambientais, segundo Watanabe-Caramello (2012), podem ser reunidas em dois grupos: questão ambiental e sociedade, que se configura como uma dimensão mais ampla sobre a questão ambiental, seus impactos e reflexos na sociedade; e questão ambiental e educação, em que estão presentes as reflexões voltadas à educação e ao ensino na perspectiva socioambiental.

Para o primeiro grupo, aparece a análise sobre a aprendizagem social na gestão de recursos rurais e a justiça ambiental, em especial ao tratar do ambientalismo dos pobres. Há, nos discursos ambientais, duas explicações comumente usadas, uma de caráter ecológico e outra de natureza econômica e política, olhando a expansão da atividade econômica e os seus impactos socioambientais. (WATANABE-CARAMELLO, 2012, p. 24)

Marcam presença, também, ainda no primeiro grupo, três discursos ambientais que se estabelecem no âmbito social: o arcádico, baseado em um discurso bucólico, que prega uma natureza sem preço, de calor estético e espiritual; o do ecossistema, baseado no discurso científico e que busca exemplificar que a interferência humana é perturbadora do equilíbrio da natureza; e o da justiça, baseado nas questões sobre os direitos civis, que prega os direitos dos cidadãos de viver e trabalhar em um ambiente saudável. (HANNIGAN, 2009²4 apud WATANABE-CARAMELLO, 2012)

No segundo grupo, denominado questão ambiental e educação, temos abordagens que mencionam conceitos como "empresa sustentável”, “comunidades verdes” e "casas ecológicas”. Esse conjunto de abordagens, segundo Lima (2002), se configuram com um conservadorismo dinâmico, sendo paliativas e sendo veiculadas na mídia "com a intenção de mascarar a insatisfação pública e desmobilizar as possíveis reações populares que evidenciam os prejuízos causados pela degradação do meio.” (LIMA, 2002 apud WATANABECARAMELLO, 2012, p. 27)

24 HANNIGAN, J. Environmental Sociology. São Paulo: Editora Unesp, 2009. 
Também dentro do segundo grupo e considerando especificamente o ramo da educação, Lima (2002) estrutura a Educação Ambiental em duas linhas, a perspectiva conservadora, em que "prevalece a concepção reducionista e simplificadora e uma visão de que a tecnologia pode ser a fonte salvadora dos problemas ambientais” e a perspectiva emancipatória, em que "busca-se uma visão complexa e multidimensional e incentiva-se um posicionamento crítico e politizado diante dos problemas ambientais.” (LIMA, 2002 apud WATANABECARAMELLO, 2012, p. 28)

As denominações aqui mencionadas são apenas uma parte da grande quantidade de abordagens presentes na Pesquisa em Ensino de Ciências voltadas à promoção da cidadania. A Educação Ambiental e a Abordagem Temática Freireana, por exemplo, também são denominações recorrentes na área preocupadas com o incentivo da cidadania, mas que não receberam atenção neste capítulo.

Apesar do recorte realizado, consideramos que o conjunto de abordagens aqui reunido, assim como as definições e pressupostos identificados, embora longe de representarem a totalidade da produção da área, sejam suficientes para evidenciar a multiplicidade de compreensões existentes, assim como algumas de suas especificidades quando implementadas em sala de aula e algumas de suas convergências.

Na tentativa de aprofundar as compreensões destas ênfases para a realização do diálogo com os professores, apresentamos, no capítulo seguinte, o referencial teórico usado para sistematizar esta amplitude de caminhos possíveis. Mais adiante, detalharemos a metodologia de análise da produção da área voltada à Pesquisa em Ensino de Ciências que se propõe a incentivar a promoção da cidadania e os resultados obtidos ao longo de nossa busca. 


\section{Capítulo 3 - Referencial para compreender as perspectivas educacionais}

Nos dois capítulos anteriores foram explicitadas várias concepções de cidadania, assim como algumas das formas que ela pode ser colocada em prática no ensino de ciências. Foram discutidas as compreensões deste conceito nos documentos oficiais, suas defesas e regulamentações; o contexto social e político em que a cidadania e as práticas com este fim estão inseridas e que não pode ser desconsiderado; alguns aspectos específicos da ciência e seu processo de construção; e, finalmente, algumas abordagens presentes de maneira recorrente na Pesquisa em Ensino de Ciências voltas à promoção da cidadania, evidenciando que não há uma completa concordância dentro de cada uma delas.

Diante deste cenário de múltiplas abordagens, elegemos a matriz de referências desenvolvida por Roseline Beatriz Strieder (STRIEDER, 2012 e STRIEDER e KAWAMURA, 2017) como ferramenta capaz de apontar encaminhamentos e sistematizações essenciais para que seja possível dialogar com a prática docente, auxiliando os professores a materializar atividades voltadas à cidadania que sejam condizentes com suas realidades de trabalho e suas visões de mundo.

Apesar da matriz ter sido desenvolvida com as abordagens CTS em mente, acreditamos que os Propósitos Educacionais, uma de suas duas dimensões principais, se constituam como uma dimensão capaz de ser utilizada em contextos mais amplos, como atividades voltadas à promoção da cidadania no ensino de ciências, área de nosso interesse.

Segundo a autora, diante da polissemia do movimento CTS, o objetivo de seu trabalho “é buscar identificar abordagens CTS presentes no Ensino de Ciências, apresentando aproximações e distanciamentos entre as mesmas.” (STRIEDER, 2012, p. 17)

Para que isso fosse possível, foi realizada, inicialmente, uma primeira análise dos trabalhos com ênfase CTS no Ensino de Ciências, possibilitando um primeiro panorama das pesquisas e a construção de um estado da arte da área.

$\mathrm{Na}$ construção da matriz propriamente dita, foram privilegiadas duas dimensões específicas: uma sobre a maneira como as relações entre Ciência, Tecnologia e Sociedade são abordadas e outra sobre as diferentes perspectivas educacionais envolvidas. Segundo a autora, estas duas dimensões (STRIEDER, 2012, p. 19): 
representam uma maneira de articular discussões que vêm ocorrendo em diferentes áreas do conhecimento e se cruzam no âmbito da Educação Científica com Enfoque CTS, dentre elas, a função social da escola, da educação científica, da ciência e da tecnologia; e, além disso, "função" para qual modelo de sociedade. Ou seja: Que sociedade, que escola, que ciência, que tecnologia e que educação científica queremos?

A matriz, assim, é composta por duas dimensões, que se articulam e estão intimamente relacionadas. A primeira delas, denominada Parâmetros CTS, busca identificar quais são as concepções de Ciência, Tecnologia e Sociedade adotadas por trabalhos que se dedicam a abordagens CTS, assim como a maneira com que estes três elementos se relacionam. A segunda dimensão, denominada Propósitos Educacionais, identifica quais são as concepções de educação e quais os objetivos pretendidos por seus idealizadores, sendo influenciada pela perspectiva freireana de educação.

Para a primeira dimensão, isto é, sobre a maneira como as relações entre CTS são abordadas, foram consultados "referenciais de certa forma externos ao movimento CTS no campo educacional; que discutem a ciência, a tecnologia e suas relações com a sociedade” (STRIEDER, 2012, p. 19).

Foram lançados, assim, “olhares para a Ciência”, “olhares para a Tecnologia” e “olhares para a Sociedade”. No primeiro desses olhares, são destacadas e discutidas várias concepções de ciência, buscando definir o que ela seria, qual o seu processo de construção e qual a validade e possíveis limites de seus conhecimentos.

São citadas as compreensões de ciência como baseadas no indutivismo, defendida por Francis Bacon; refutacionismo, proposta por Karl Popper; contextualismo, defendida por Thomas Kuhn; diferenciacionista, idealizada por Robert Merton; antidiferenciacionista, proposta pelo Programa Forte; transversalista, defendida por Pierre Bourdieu; e, finalmente, baseada em valores, proposta por Hugh Lacey.

Nos “olhares para a Tecnologia”, por sua vez, são mencionadas e discutidas várias concepções de tecnologia, dando especial atenção tanto para sua definição e sua relação com a ciência, quanto às relações entre tecnologia e desenvolvimento social, na forma da Política Científico Tecnológica.

Aparecem, aqui, concepções de Tecnologia como estudo da técnica, concebendo esta apenas como o estudo e desenvolvimento de técnicas e produtos; relações com a Ciência, tomando a tecnologia como intrinsecamente relacionada à Ciência; artefato/instrumento, tecnologia como uma ferramenta; organização de ações, tecnologia como relacionada à 
técnica; sistema de relações, tecnologia como considerando o contexto humano de uso e compreensão da tecnologia; adequação sociotécnica, tecnologia entendida como construção social, trazendo consigo valores e interesses; e, por fim, tecnologia social, tecnologia como desenvolvimento de técnicas que atendam aos interesses sociais.

Nos "olhares para a Sociedade", finalmente, são discutidas algumas concepções de sociedade e de como ela se relaciona com a Ciência e a Tecnologia, detalhando como estas a influenciam.

São discutidas concepções de sociedade como fundamentadas em um distanciamento, isto é, tendo a Ciência como detentora de um saber incontestável; alienação, onde a população valoriza a tecnologia, mas fica alienada com relação à ciência e à cultura; riscos, ameaças e incertezas, quando a sociedade se sente ameaçada e com incertezas sobre o processo de modernização da sociedade industrial; elementos para compreendê-la, quando há necessidade de se considerar as dimensões social e econômica nos problemas científicos e ambientais na construção da ciência; e, finalmente, reformar o pensamento, quando há uma tentativa de mudar o pensamento da sociedade a respeito de sua participação na ciência, tornando-as parte das discussões e tomadas de decisão.

A tabela 1, a seguir, resume os olhares sobre a Ciência, a Tecnologia e a Sociedade identificados pela autora:

Tabela 1 - Olhares sobre a Ciência, Tecnologia e Sociedade

\begin{tabular}{ccc}
\hline Ciência & Tecnologia & Sociedade \\
\hline Indutivista & Estudo da técnica & Distanciamento \\
\hline Refutacionista & Relações com a Ciência & Alienação \\
\hline Contextualizado & Artefato/Instrumento & Riscos, ameaças e incertezas \\
\hline Diferenciacionista & Organização de ações & Elementos para compreendê-la \\
\hline Antidiferenciacionista & Sistema de relações & Reformar o pensamento \\
\hline Transversalista & Adequação sociotécnica & \\
\hline Valores & Tecnologia social & \\
\hline
\end{tabular}
Fonte: (STRIEDER, 2012, p. 139).

Além da dimensão Parâmetros CTS, voltada para a maneira como as relações entre Ciência, Tecnologia e Sociedade são abordadas, temos uma segunda, denominada Propósitos Educacionais, que se volta para as diferentes perspectivas educacionais envolvidas nas atividades. Para esta dimensão, foi utilizada a perspectiva de educação do educador brasileiro 
Paulo Freire, escolha que se justifica não apenas porque a autora compartilha de seus pressupostos, mas, também, pela sua afinidade com algumas das abordagens CTS.

Para Freire, é central a concepção de ser humano como ser inacabado, que busca sempre ser mais. Esta busca por ser mais só é possível quando associada à busca do ser humano por sua emancipação enquanto sujeito/agente de transformação de sua realidade, pois, quando isso não acontece, temos uma não transformação da realidade e de si mesmo, com uma consequente adaptação, sem qualquer mudança.

Contudo, para Freire, a realidade não é imediatamente evidente ao ser humano, sendo necessário, primeiro, tomar consciência dela e reconhecer a existência da capacidade de transformá-la. Esta tomada de consciência, contudo, só é possível a partir de um olhar crítico, capaz de desvelar a realidade para conhecê-la.

Aparece, aqui, a distinção entre a educação bancária e a educação problematizadora, sendo apenas esta forma de educação capaz de proporcionar uma leitura crítica de mundo e o rompimento da cultura do silêncio, permitindo aos estudantes terem a sua voz e a agirem de maneira a transformar a realidade.

Vários autores propõem articulações entre os pressupostos freireanos e o enfoque CTS, apontando várias convergências, como a busca pela cultura de participação em questões relacionadas à CTS, a necessidade da articulação entre várias disciplinas, a escolha e abrangência dos temas estudados, entre outras.

Há, contudo, alguns distanciamentos entre Freire e o enfoque CTS. Para Freire, é central que os temas trabalhados tenham significado para os alunos, que eles sejam discutidos a partir da realidade próxima deles, enquanto no enfoque CTS, esse não aparenta ser um aspecto tão relevante. No que diz respeito à definição dos temas trabalhados, Freire defende que a comunidade escolar participe na sua definição, mas, em propostas CTS, geralmente são os professores que propõe o tema. No que diz respeito às disciplinas envolvidas, em CTS aparecem, predominantemente, disciplinas pertencentes às ditas ciências exatas, enquanto que em Freire, não há restrição a este campo do conhecimento. (STRIEDER, 2012, p. 151)

A partir das articulações entre os pressupostos freireanos e o enfoque CTS, a autora afirma que (STRIEDER, 2012, p. 161):

a formação de cidadãos perpassa por diferentes intenções, que, envolvem, num primeiro momento, reconhecer e compreender o problema em questão. Porém, a nosso ver (e com base em pressupostos freireanos) isso não basta, é preciso também, caminhar em busca do desenvolvimento de outra postura frente à situação, de uma postura critica, de questionamento. Além disso, 
torna-se imprescindível iniciar o desenvolvimento de uma cultura de participação, de intervenção nessas situações.

A autora distingue, assim, três Propósitos Educacionais, que buscam o desenvolvimento de Percepções, de Questionamentos e de Compromisso Social. Segundo ela (STRIEDER, 2012, p. 166, negrito da autora):

(i) Uma educação científica que contribua para o desenvolvimento de percepções entre o conhecimento científico escolar e o contexto do aluno. Relaciona-se à construção de uma nova imagem do conhecimento científico escolar, dando ênfase tanto para questões presentes no dia-a-dia, quanto para questões científicas e tecnológicas. Nesse caso, os aspectos mais relacionados à ciência, à tecnologia e à sociedade contribuem para contextualizar o conhecimento científico a ser trabalhado, buscando uma aproximação com a vivência cotidiana do aluno.

(ii) Uma educação científica que contribua para o desenvolvimento de questionamentos sobre situações que envolvem aspectos de ciência, tecnologia e/ou sociedade. Mais do que contextualizar o conhecimento científico escolar, pretende discutir as implicações do desenvolvimento científico-tecnológico na sociedade, busca uma compreensão sobre uma utilização responsável dos recursos naturais e aparatos tecnológicos.

Finalmente, (iii) uma educação que busca o desenvolvimento de compromisso social busca dar condições para uma leitura crítica da realidade, para que, mais do que contextualizar o conhecimento, compreender o mundo, questioná-lo e/ou se posicionar, seja buscada uma transformação do mundo. (STRIEDER, 2012, p. 171)

A autora ressalta que esses propósitos podem ser entendidos como complementares, desempenhando um papel importante na busca por mudanças no processo de ensinoaprendizagem. Não há, assim, qualquer forma de hierarquia entre esses propósitos, como ressalta a autora (STRIEDER, 2012, p. 173):

Ainda que possa parecer existir uma hierarquia implícita nessa forma de identificação e apresentação das perspectivas educacionais, não é essa nossa intenção. Diferentes intenções correspondem a diferentes situações, contextos escolares e possibilidades de atuação, ou mesmo a momentos sucessivos de apropriação das intenções do movimento CTS.

Cada um desses propósitos educacionais está associado a determinadas visões de ciência, tecnologia e sociedade, assim como a determinadas visões de Racionalidade Científica, Desenvolvimento Tecnológico e Participação Social, parâmetros que surgem da articulação das dimensões CTS.

Esses parâmetros compõe a dimensão Parâmetros CTS da matriz de referências, preocupada com as relações entre Ciência, Tecnologia e Sociedade, estando diretamente ligados aos Propósitos Educacionais integrantes da outra dimensão. Eles carregam consigo 
uma intencionalidade específica, que é a explicitação das características das Percepções, Questionamentos e Compromissos Sociais que se pretende promover com a inserção da abordagem CTS na educação. (STRIEDER, 2012, p. 175)

Sobre as características e intenções desse três parâmetros, a autora afirma que (STRIEDER, 2012, p. 176, itálico da autora):

A racionalidade científica, ainda que diretamente relacionada à ciência, não se reduz a ela. Permite, por exemplo, considerações sobre as implicações do modelo de ciência, dito "racional", às culturas. Com isso, a crítica não está centrada na ciência em si, mas no modelo de ciência que temos, que se insere, por sua vez, num modelo de sociedade. Estamos reconhecendo que, o que entra em jogo na discussão CTS, é menos a ciência em si, e mais os âmbitos atribuídos, reconhecidos e reivindicados para a racionalidade. O mesmo paralelo pode ser feito entre o parâmetro desenvolvimento tecnológico e tecnologia: a crítica não recai à tecnologia, mas ao modelo de desenvolvimento, que vem associado ao modelo de ciência e de sociedade. Também, não caberia analisar compreensões de sociedade, mas, sim, o papel que cabe à sociedade nesse mundo "científico e tecnológico", ou "racional e desenvolvimentista", ou seja, as diferentes possibilidades de participação social.

Cada um desses três parâmetros, isto é, Racionalidade Científica, Desenvolvimento Tecnológico e Participação Social, possui cinco níveis de compreensão, articulando elementos da tríade CTS e compondo um panorama das possíveis abordagens CTS presentes no contexto brasileiro de Ensino de Ciências. Estes (STRIEDER, 2012, p. 177)

diferentes níveis possíveis para cada um dos parâmetros, (...) de certa forma, representam, em um extremo, posições mais ingênuas e, em outro, posições mais críticas sobre os mesmos.

A tabela 2, a seguir, apresenta os cinco níveis de compreensão para cada um dos parâmetros. Estes níveis obedecem a certa gradatividade, indo de posições menos críticas para mais críticas, e serão brevemente discutidos a seguir:

Tabela 2 - Níveis de compreensão sobre Racionalidade, Desenvolvimento e Participação

\begin{tabular}{ccc}
\hline Racionalidade & Desenvolvimento & Participação \\
\hline $\begin{array}{c}\text { (1R) Desocultamento da } \\
\text { realidade }\end{array}$ & (1D) Neutro & (1P) Reconhecimento \\
\hline (2R) Universal & (2D) Sinônimo de progresso & (2P) Decisão Individual \\
\hline (3R) Em contexto & (3D) Especificidades & (3P) Decisão Coletiva \\
\hline (4R) Questionada & (4D) Orientado & (4P) Mecanismos de Pressão \\
\hline (5R) Insuficiente & (5D) Em contexto & (5P) Esferas Políticas \\
\hline
\end{tabular}

Fonte: (STRIEDER, 2012, p. 177). 
Sobre os níveis da Racionalidade Científica, a autora afirma que (STRIEDER, 2012, p. 180):

\begin{abstract}
Num primeiro e segundo níveis, menos críticos, temos o reconhecimento de um modelo de racionalidade associado a uma garantia de desocultamento da realidade; no primeiro, sem juízo de valor; no segundo, o juízo volta-se aos usos da ciência. Num nível intermediário, temos o reconhecimento de limitações do modelo de racionalidade empregado para a construção da ciência, tanto no que se refere a sua produção, quanto na definição dos rumos e implicações sociais de suas pesquisas. Por fim, num nível mais crítico, temos o reconhecimento da racionalidade enquanto necessária para a construção da ciência, porém não única nem suficiente.
\end{abstract}

1R) Racionalidade como garantia de desocultamento da realidade - Ciência para compreender o mundo: A ciência é tida como capaz de desvelar a realidade e fornecer a verdade absoluta. Sua racionalidade seria autônoma e livre de juízos de valores.

2R) Racionalidade universal - Ciência boa ou má: A racionalidade da ciência não é questionada, sendo apenas seus produtos passíveis de reflexão e questionamento. Os resultados da ciência seriam sempre positivos em si mesmos, sendo tarefa da sociedade escolher sobre seu uso para o bem ou para o mal.

3R) Racionalidade em contexto - Ciência vulnerável e provisória: Ciência como desocultadora da realidade, mas como uma construção humana, não neutra e provisória, fruto de uma construção social e histórica.

4R) Racionalidade questionada - Ciência limitada pelas práticas sociais: Crítica aos rumos das pesquisas, nas razões para se pesquisar determinados problemas e não outros. São importantes as questões de poder e interesses como influenciadoras na ciência, fazendo esta nem sempre perseguir o progresso.

5R) Racionalidade assumida mas insuficiente - Ciência insuficiente: Reconhecimento da racionalidade científica, mas esta é considerada como insuficiente para compreender a complexidade do mundo contemporâneo e resolver os problemas da realidade.

Sobre os níveis do Desenvolvimento Tecnológico, a autora afirma que (STRIEDER, 2012, p. 191):

Num primeiro e segundo níveis, menos críticos, temos o reconhecimento de um modelo de desenvolvimento neutro e associado a uma garantia de progresso; no primeiro, sem a necessidade de juízo de valor; no segundo, o juízo volta-se às aplicações da tecnologia. Nesse contexto, portanto, a tecnologia parece mais funcional e menos social do que de fato é; e o desenvolvimento vem como consequência, sem necessidade de questionamentos. 
Num nível intermediário, temos o reconhecimento de especificidades do conhecimento tecnológico, em especial, do ponto de vista de sua produção. A tecnologia é entendida como uma classe de conhecimento e não como ciência aplicada, inicia-se a quebra do modelo linear de desenvolvimento, no sentido em que tecnologia não é aplicação direta de conhecimento científico.

Por fim, num nível mais crítico, temos a quebra do modelo linear, construída sob dois pontos de vista - por um lado no reconhecimento de que há propósitos associados ao desenvolvimento e, por outro, na defesa de um modelo de desenvolvimento que considere as especificidades do contexto.

1D) Desenvolvimento neutro - Tecnologia enquanto aparato presente na sociedade: Desenvolvimento científico-tecnológico como neutro, não influenciando a sociedade e nem por ela influenciado, como nem negativo e nem positivo. Tecnologia como ferramenta.

2D) Desenvolvimento como sinônimo de progresso social - Tecnologia enquanto ciência aplicada: Desenvolvimento tecnológico analisado segundo as implicações sociais positivas. Mais ciência e tecnologia como geradores inevitáveis de mais bem-estar social.

3D) Desenvolvimento e suas especificidades - Tecnologia como classe de conhecimento: Tecnologia como não decorrente imediatamente de ciência, mas sim como diferente da técnica e influenciada pela sociedade.

4D) Desenvolvimento orientado - Tecnologia contém propósitos políticos: Progresso científico como servindo para promover interesses de poucos, e não às necessidades básicas da população. Crise ambiental associada ao desenvolvimento desenfreado da tecnologia.

5D) Desenvolvimento em contexto - Tecnologia voltada às necessidades básicas: Desenvolvimento tecnológico como inserido num contexto, devendo ser pensado de forma a satisfazer às necessidades básicas da população e não à geração de lucro econômico.

Finalmente, sobre os níveis da Participação Social, a autora afirma que (STRIEDER, 2012, p. 202):

Num primeiro nível encontra-se a perspectiva da informação (e não da tomada de decisão propriamente dita) que se dá pelo reconhecimento da presença da CT na sociedade. Num segundo nível, a participação ocorre num contexto micro, a partir de decisões de cunho mais individual, em geral relacionadas aos produtos da CT. No terceiro nível as decisões já envolvem o contexto macro, são coletivas e abarcam a discussão de problemas e impactos da CT na sociedade. No quarto nível, a participação se dá a partir do reconhecimento das contradições e por mecanismos de pressão, centradas, principalmente, no processo de produção. No quinto e último nível, a participação se dá no âmbito das esferas políticas, a partir da compreensão e discussão de políticas públicas.

1P) Reconhecimento da presença da CT na sociedade: Reconhece temas presentes na mídia e no dia a dia como pertencentes à temática CT, tais como mudanças climáticas, 
questões energéticas e equipamentos tecnológicos. Os conhecimentos envolvidos são apenas os científicos.

2P) Decisões Individuais - Discussão de Riscos e Benefícios: Participação da sociedade ocorrendo na forma de avaliação de pontos positivos e negativos do uso de determinado produto da CT, de maneira mais local ou individual.

3P) Decisões Coletivas - Discussão de problemas e impactos ou transformações: A participação social passa pelo reconhecimento das transformações sociais/culturais causadas pelo desenvolvimento científico-tecnológico, envolvendo também decisões coletivas.

4P) Mecanismos de Pressão - Identificação de contradições: A participação social passa pelo reconhecimento dos propósitos políticos que levaram ao desenvolvimento de determinado produto da CT. Há a possibilidade, aqui, de intervir no processo de produção e/ou implementação de determinado produto da CT.

5P) Esferas Políticas - Compreensão e discussão de políticas: A participação social se dá no âmbito das políticas públicas, na definição de seus objetivos, meios para alcançá-los e maneiras de controlar sua implementação.

Segundo a autora, o que guia e o que dá sentido às diferentes perspectivas de Racionalidade Científica, Desenvolvimento Tecnológico e Participação Social, no âmbito dos trabalhos sobre CTS, são os propósitos da educação científica. Eles se relacionam da seguinte maneira (STRIEDER, 2012, p. 206-208):

A busca pelo desenvolvimento de percepções está relacionada a uma abordagem menos crítica de Racionalidade, Desenvolvimento e Participação. Centrada na mudança das metodologias de ensino e nos processos de ensinoaprendizagem, em geral, deixa de aprofundar essas discussões; sendo que, em extremos, as visões sobre Racionalidade e Desenvolvimento, acabam referendando a ideia de neutralidade da ciência e da tecnologia. Já as discussões sobre a participação, quando presentes, recaem no reconhecimento da presença da CT na sociedade. (...)

O desenvolvimento de questionamentos, por sua vez, implica em abordar a Racionalidade, o Desenvolvimento e a Participação em níveis intermediários. Por exemplo, discutindo os antecedentes e as implicações sociais da ciência e da tecnologia, destacando a não neutralidade da produção científico-tecnológica e, associado a isso, buscando a participação da sociedade, seja do ponto de vista das tomadas de decisão individuais (discutindo riscos e benefícios) e/ou coletivas (discutindo impactos ou transformações sociais) ou a partir de mecanismos de pressão, identificando contradições presentes, principalmente, no momento de produção da CT. (...)

Para o desenvolvimento de Compromisso Social é necessário abordar a Racionalidade Científica, o Desenvolvimento Tecnológico e a Participação 
Social em seus níveis mais críticos. Buscando, por exemplo, discutir as limitações do conhecimento científico para compreender e resolver os problemas sociais, sejam eles locais ou globais; enfatizando a importância de almejarmos outro modelo de desenvolvimento, que busque satisfazer as necessidades básicas de uma determinada população e não gerar lucro econômico; e, buscando uma cultura de participação no âmbito das políticas públicas, na definição de objetivos, meios para alcançá-los e maneiras de controlar sua implementação.

A figura 1, a seguir, resume os diferentes níveis de Racionalidade Científica, Desenvolvimento Tecnológico e Participação Social, assim como sua relação com os três Propósitos Educacionais. ${ }^{25}$

Figura 1 - Relação entre parâmetros e propósitos da educação CTS

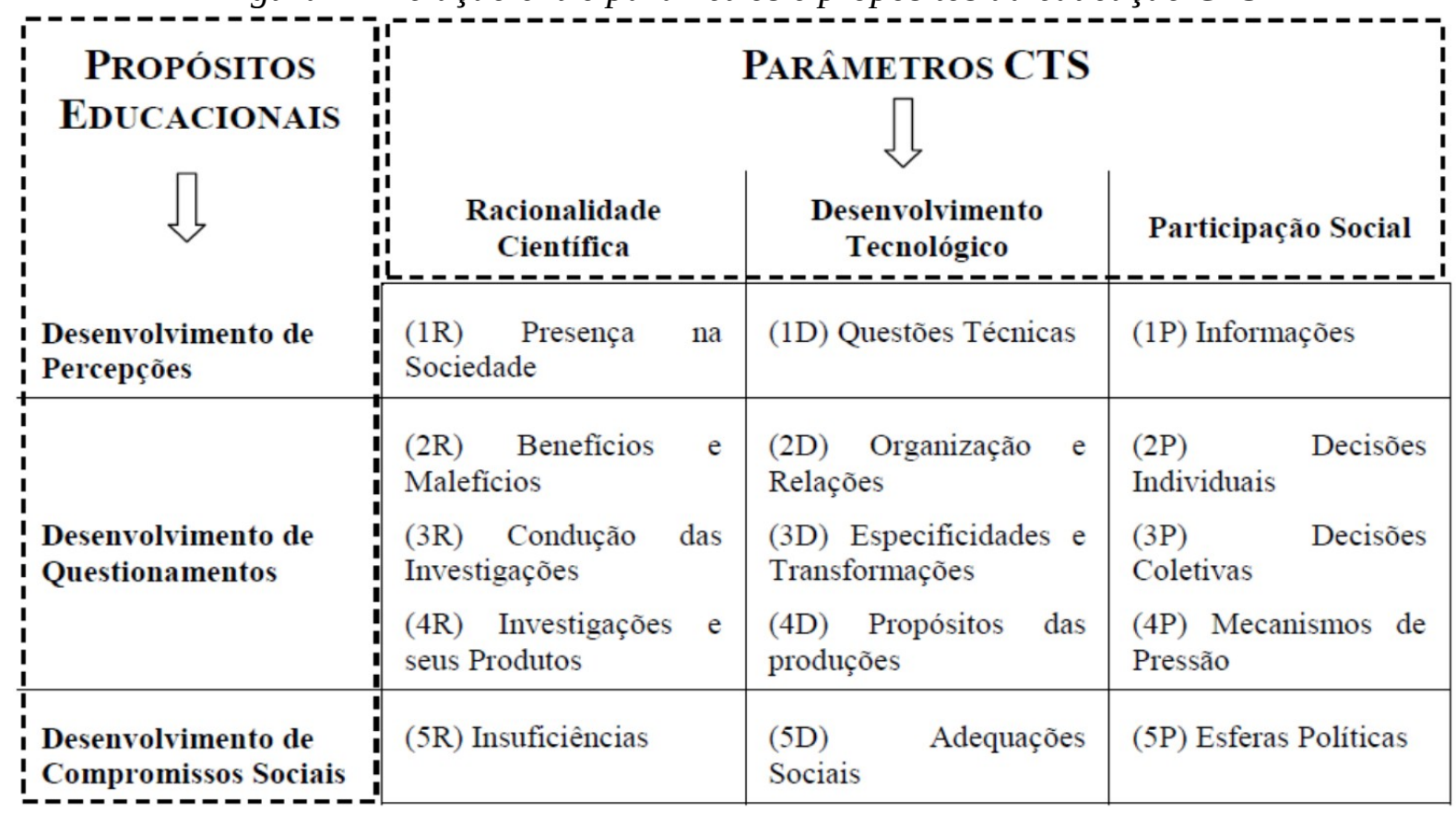

(STRIEDER e KAWAMURA, 2017)

Novamente, ainda que a matriz tenha sido construída com o objetivo de analisar atividades que realizam abordagens CTS, a dimensão dos Propósitos Educacionais se constitui como algo mais geral. Segundo a autora (STRIEDER, 2012, p. 167):

esses propósitos não representam somente "propósitos educacionais CTS", mas, acima de tudo, propósitos da Educação Científica. Sendo que sua presença pode ser reconhecida em diferentes períodos da história da educação (KRASILCHIK, 1987).

Tal como defende a autora, consideramos que os Propósitos Educacionais não estão limitados aos Parâmetros CTS, podendo se relacionar com os objetivos gerais da educação

25 Alguns dos níveis aparecem com diferenças de denominação neste esquema, assim como com descrições ligeiramente diferentes, quando comparados com os apresentados na Tese. Essas diferenças, contudo, não comprometem a matriz propriamente dita. 
voltada à cidadania e com as posturas que se pretende que os estudantes assumam em sociedade, a partir dos conhecimentos científicos trabalhados em sala.

Assim, entendemos que os Propósitos Educacionais podem ser usados tanto com as abordagens CTS, quanto com abordagens que visam a promoção da cidadania no ensino de ciências de maneira mais geral, como as abordagens de Alfabetização Científica, Questões Sociocientíficas, Questões Controversas e Questões Socioambientais.

Vale a pena ressaltar que os três Propósitos Educacionais, isto é, o desenvolvimento de Percepções, de Questionamentos e de Compromisso Social, tal como apontado pela autora (STRIEDER, 2012, p. 173), não apresentam entre si qualquer forma de hierarquia. Eles estão relacionados, de fato, a diferentes contextos escolares, a distintas possibilidades de atuação e a cenários em que a atuação docente pode ser mais ou menos flexível, sempre estando sujeita às mais variadas influências.

Acreditamos que estes propósitos podem se mostrar úteis para compreender as várias concepções de cidadania presentes na Pesquisa em Ensino de Ciências, assim como as especificidades das várias abordagens que aparecem com denominações específicas, nos auxiliando a identificar tendências e aproximações. Esses propósitos são essenciais, portanto, para a compreensão deste cenário, sua sistematização e posterior diálogo com os professores, buscando auxiliá-los a exercer sua atividade docente. 


\section{Capítulo 4 - Metodologia utilizada na compreensão das abordagens visando a cidadania}

Em uma aproximação inicial à questão de pesquisa, foram apresentadas, no Capítulo 2, cinco abordagens que, de alguma forma, envolvem preocupações com a promoção da cidadania no Ensino de Ciência. São elas Alfabetização Científica, Ciência, Tecnologia, Sociedade e Ambiente, Questões Sociocientíficas, Questões Controversas e Questões Socioambientais, sendo que cada uma apresenta também muitas compreensões, definições e encaminhamentos.

Esta grande diversidade de encaminhamentos pode ser melhor compreendida tanto a partir de um aprofundamento dos pressupostos teóricos apresentados e discutidos anteriormente, quanto a partir da forma como estas abordagens são estudadas e colocadas em prática pela Pesquisa em Ensino de Ciências.

Considerando os objetivos dessa pesquisa, a compreensão e sistematização das cinco abordagens destacadas e seus respectivos encaminhamentos são essenciais para a concretização de uma sistematização da produção acadêmica voltada à promoção da cidadania no ensino de ciências. Sua compreensão e sistematização são essenciais, também, para a busca de um diálogo com a prática docente, para um aprofundamento das possíveis práticas em sala de aula.

Nesse sentido, no presente trabalho, optamos pelo desenvolvimento, de uma metodologia qualitativa, de cunho bibliográfico, do tipo estado do conhecimento, que permite identificar os movimentos de pesquisa relacionados a um dado tema. A importância da escolha por uma metodologia de pesquisa adequada, considerando as especificidades da área educacional, é ressaltada por diversos autores, dentre eles Severino (2017) e Saviani (2006). Na nossa proposta, essa estratégia pode ser relevante por permitir articular as considerações teóricas com abordagens e análises de cunho empírico.

Uma metodologia do tipo estado do conhecimento tem por objetivo localizar e sistematizar as contribuições das pesquisas sobre um determinado tema (no contexto de uma dada área), em um certo período temporal (MOROSINI e FERNANDES, 2014). Ou seja, trata-se de buscar recuperar a produção de conhecimento em uma dada área, identificando as questões centrais abordadas, examinando as tendências e características investigativas, os âmbitos dos problemas tratados, etc. 
Alguns autores tratam essas pesquisas da mesma forma que pesquisas em estado da arte (FERREIRA, 2002, p. 257):

Definidas como de caráter bibliográfico, elas (pesquisas conhecidas pela denominação de estado da arte ou estado do conhecimento) parecem trazer em comum o desafio de mapear e de discutir uma certa produção acadêmica em diferentes campos do conhecimento tentando responder que aspectos vem sendo destacados e privilegiados em diferentes épocas e lugares, e de que formas e em que condições têm sido produzidas certas dissertações de mestrado, teses de doutorado, publicações em periódicos e comunicações em anais de congressos e de seminários.

No entanto, as pesquisas em estado do conhecimento distinguem-se delas não tanto pelas estratégias adotadas, mas, principalmente, pelos objetivos, que são mais localizados e pontuais, permitindo análises com abordagens específicas. Além disso, têm um grande potencial ao serem utilizadas, sobretudo, para pesquisas em áreas que estão sendo ainda consolidadas, onde referências teóricas mais gerais nem sempre fornecem parâmetros suficientes ou adequados.

De forma geral, a escolha por essa abordagem de pesquisa tem justificativas amplas, mas visa quase sempre à apropriação de uma produção temática, de forma a sistematizar as contribuições de diferentes pesquisadores e, ao mesmo tempo, identificar parâmetros não necessariamente explicitados (MORAES e PEIXOTO, 2017).

No caso presente, o levantamento do estado do conhecimento será desenvolvido tomando como base a identificação dos movimentos de constituição das preocupações com a cidadania, em âmbito relativamente recente, no ensino de ciências.

Romanowski e Ens (2006) afirmam que para desenvolver pesquisas desse tipo é necessário compreendê-las como um estudo tanto descritivo, pois produz uma situação com uma condição específica e de amostra aleatória, como também de natureza geral e analítica.

Afirmam, ainda, a necessidade de atentar para, dentre outros: (i) a localização de um campo pertinente para a investigação (bancos de pesquisas, teses e dissertações, catálogos e acervos de bibliotecas, biblioteca eletrônica que possam proporcionar acesso a coleções de periódicos, assim como aos textos completos dos artigos); (ii) a definição de descritores adequados para direcionar as buscas e seleções relativas ao tema; (iii) o estabelecimento de critérios para a seleção do material que venha a compor diferentes corpus de análise; (iv) a definição de parâmetros e/ou categorias apropriadas para os encaminhamentos das análises.

Portanto, as informações a respeito dos objetivos formativos das cinco abordagens apontadas, algumas de suas principais características e alguns dos fatores que dizem respeito a 
sua prática em sala podem ser obtidos a partir de uma busca empírica, capaz, também, de identificar eventuais aproximações e afinidades entre elas.

Essa busca empírica se desenvolve em duas aproximações de análises complementares e com especificidades distintas. A primeira delas é mais geral ou panorâmica, com grande amostra de trabalhos e tratamento semi-quantitativo de dados. Ela tem como preocupação identificar os objetivos formativos dos trabalhos, assim como algumas de suas características, aproximações e afinidades.

A segunda análise, por sua vez, conta com quantidade reduzida de trabalhos, sendo mais local e aprofundada, sem rigor estatístico, voltando-se para os fatores que influenciam as práticas em sala de aula.

\subsection{Estado do conhecimento: corpus de análise}

Em trabalhos dessa natureza, é importante ressaltar com clareza o conjunto de produções a serem investigadas e analisadas, assim como a delimitação do período abordado, na medida em que os resultados a serem obtidos estarão diretamente relacionados às definições do corpus de análise.

Nesse caso, para identificar as diferentes abordagens de cada uma das cinco temáticas, realizamos um levantamento da produção da área nas últimas três edições do Encontro Nacional de Pesquisa em Educação em Ciências (ENPEC), isto é, a IX, de 2013, a X, de 2015 e a XI, de 2017.

A escolha deste evento se justifica por acreditarmos que ele apresenta um bom retrato da produção acadêmica dos principais pesquisadores da área, compreendendo trabalhos em estágio avançado de desenvolvimento. Consideramos, também, que a cidadania não está restrita a apenas uma disciplina e este evento, por englobar as três principais áreas das chamadas Ciências Naturais, ou seja, a Física, a Química e a Biologia, bem como suas articulações, possibilitará um panorama mais geral.

Vale a pena destacar que os trabalhos publicados neste evento devem conter de 8 a 10 páginas, o que dificulta um maior detalhamento no referencial teórico adotado ou na descrição de atividades didáticas aplicadas. Além disso, não são aceitos, neste evento, projetos de pesquisa e relatos de experiência. 
Eventos como o Simpósio Nacional de Ensino de Física (SNEF), o Encontro Nacional de Ensino de Química (ENEQ), e o Encontro Nacional de Ensino de Biologia (ENEBIO), quando comparados com o ENPEC, são mais abertos para a participação de professores da educação básica e a relatos de experiência, mas acabam por priorizar apenas uma das Ciências Naturais e não se constituem como os locais preferidos dos pesquisadores em ensino de Ciências para publicar seus trabalhos.

Para a seleção dos trabalhos, buscamos, nas três edições do ENPEC, todos aqueles que estavam dentro da linha temática denominada “Alfabetização científica e tecnológica, abordagens CTS e CTSA e educação em ciências”, bem como aqueles que apresentavam como palavras-chave os nomes das ênfases de interesse e expressões como "cidadania”, “controvérsias” e "socioambiental”.

O número de pesquisas selecionadas em cada edição do evento e o número total de trabalhos por edição são apresentados na tabela 3, a seguir:

Tabela 3 - Quantidade de trabalhos selecionados e total por evento

\begin{tabular}{ccc}
\hline Evento & Trabalhos selecionados & Total de trabalhos por evento \\
\hline IX ENPEC (2013) & 111 & 921 \\
\hline X ENPEC (2015) & 99 & 1100 \\
\hline XI ENPEC (2017) & 133 & 1210 \\
\hline Total & 343 & 3231 \\
\hline
\end{tabular}

Fonte: Bondezan (2019).

Utilizando esse conjunto de comunicações, foram realizados dois tipos de investigação:

Na primeira análise, todos os trabalhos encontrados foram analisados considerando as informações presentes nos títulos, palavras-chave e resumos, que serão nosso corpus de análise.

Na segunda análise, para estudar os modos como os trabalhos de Pesquisa em Ensino de Ciências voltados à cidadania se concretizam na prática de sala de aula, foi necessário definir um subconjunto desse corpus. Nesse caso, o objetivo foi identificar os principais fatores que influenciam as atividades concretas desenvolvidas.

A identificação destes fatores se faz necessária na medida em que se deseja a realização de um diálogo com os professores em exercício, com a intenção de que eles 
possam realizar escolhas conscientes na realização de suas aulas, sem ignorar o contexto em que estão inseridos e suas visões individuais de educação.

Assim, para a segunda análise, foi realizado um recorte da amostra da primeira. Dos 343 trabalhos da primeira amostra, selecionamos apenas aqueles que se dedicavam ao Ensino Médio e ao Ensino Superior em Licenciaturas e apenas aqueles publicados nas últimas duas edições do ENPEC (2015 e 2017), totalizando 33 pesquisas.

A escolha destes dois níveis de ensino se justifica por estes serem, respectivamente, o ambiente de trabalho dos professores de Física, Química e Biologia, e o local de formação dos futuros professores. Ficaram de fora deste recorte não apenas os trabalhos que se referiam a outros níveis de ensino, mas aqueles que não tinham relação direta com a sala de aula, realizando reflexões teóricas ou revisões bibliográficas.

Devido ao fato de nossa análise dialogar diretamente com a abordagem cidadã em sala, foi necessário um segundo recorte para considerar apenas os trabalhos que descreviam as atividades desenvolvidas nas aulas com alguma profundidade. Foram desconsideradas, assim, as pesquisas que realizavam levantamento de concepções de professores e alunos ou que tinham como foco a análise de dados sobre atividades anteriormente aplicadas, mas que não foram detalhadas na pesquisa em questão. O corpus da segunda análise ficou reduzido, assim, a 16 trabalhos, organizados na tabela 5, que será apresentada mais adiante.

\subsection{Primeira análise: Tendências da área}

Todos os trabalhos encontrados foram analisados considerando as informações presentes nos títulos, palavras-chave e resumos. Essas informações foram analisadas segundo cinco aspectos, mencionados e descritos a seguir. Para isso, foi utilizada a Análise de Conteúdo (BARDIN, 2010), com encaminhamentos diferentes quanto à construção de categorias. A Análise de Conteúdo (ROCHA e DEUSDARA, 2005)

trata de um conjunto de técnicas de análise das comunicações que utiliza procedimentos sistemáticos e objetivos, de descrição do conteúdo das mensagens, além disso, aposta altamente no rigor como forma de não se perder na heterogeneidade de seu objeto. 
Especialmente para compreender os objetivos formativos das abordagens, a matriz de referências apresentada no capítulo anterior terá importância central, principalmente com sua dimensão Propósitos Educacionais.

Paralelamente, as principais características dos trabalhos serão obtidas identificando-se quais são as abordagens realizadas, quais os níveis de ensino que recebem atenção, quais as disciplinas curriculares a que se dedicam, entre outros aspectos.

O primeiro parâmetro de análise, denominado como "Propósitos Educacionais”, é originário da matriz de referências de Strieder (2012), apresentada e detalhada no capítulo anterior. O segundo deles é denominado “Ênfase Adotada”, compreendendo as cinco ênfases relacionadas à cidadania anteriormente discutidas.

Os outros três aspectos, denominados “Temática do Trabalho", "Natureza dos Trabalhos” e "Relação do Trabalho com a Sala de Aula”, são de cunho descritivo, buscando identificar características importantes dos trabalhos, facilitando a identificação de tendências e aproximações entre eles, assim como possibilitando um primeiro panorama das diferentes abordagens para a cidadania.

O aspecto Propósitos Educacionais identifica se os trabalhos se dedicam ao desenvolvimento de Percepções, Questionamentos ou Compromisso Social, contando com uma categoria para cada um destes propósitos. Trata-se, portanto, de categorias definidas a priori. Além dessas três categorias, uma denominada Não Aplicável inclui as pesquisas que não apresentaram no corpus de análise elementos que possibilitassem a classificação.

O segundo aspecto, a Ênfase Adotada, ${ }^{26}$ identifica se o trabalho considerado se destinava a promover uma Alfabetização Científica, uma abordagem CTS(A), Questões Sociocientíficas, Questões Controversas ou Questões Socioambientais.

Não fizemos distinção entre as expressões Letramento Científico, Alfabetização Científica e Enculturação Científica, mesmo que trabalhos como os de Sasseron e Carvalho (2011) e de Cunha (2017) apontem diferenças entre elas. Fizemos esta escolha por acreditarmos que estas denominações dizem respeito a formas de se conceber a educação não tão díspares. Trabalhos dessas naturezas foram reunidos numa categoria intitulada Alfabetização Científica.

26 Utilizamos, neste aspecto, o termo "ênfase" para se referir às cinco abordagens voltadas à promoção da cidadania no Ensino de Ciências discutidas no Capítulo 2. Esta palavra poderia ter sido substituída por "abordagem”, “enfoque” ou semelhante, mas julgamos que aquela seja mais adequada por carregar consigo uma ideia de preocupação comum. 
Embora reconhecemos as reflexões apresentadas por Ribeiro, Santos e Genovese (2015), que afirmam que as denominações “CTS” e “CTSA” acabam assumindo um papel de dissimulação de conflitos, já que ocultam um grande espectro de abordagens, reunimos elas dentro de uma categoria intitulada $C T S(A)$. Agimos desta maneira não por julgarmos que há identidade e convergência nos trabalhos encontrados, já que reconhecemos que há diferentes pontos de vista dentro da área que não são conciliáveis, pelo menos à primeira vista, mas sim porque acreditamos que essas divergências não são grandes o suficiente para justificar uma nova categoria.

Optamos por enquadrar, sempre que necessário, um mesmo trabalho dentro de mais de uma categoria e usamos como critério de classificação, em todos os casos, as informações fornecidas pelos próprios autores no corpus de nossa análise. Assim, não foi nossa intenção buscar um trabalho que de fato promovesse uma Alfabetização Científica, mas sim apenas identificar quantos e quais deles afirmam se propor a essa ênfase.

Considerar as cinco ênfases de maneira separada, embora seja um detalhamento desejável, pode acabar por se tornar excessivo, uma vez que dificultará a construção de recortes com os outros aspectos. Somado a isso, temos o fato de, ao longo da análise, percebermos que eram poucos os trabalhos que se voltavam apenas às Questões Sociocientíficas, Questões Controversas e às Questões Socioambientais, já que muitos deles fazem menção a mais de uma dessas ênfases, parecendo haver, assim, uma grande sobreposição entre elas.

Esta grande sobreposição dá indícios de que essas três ênfases não estão suficientemente consolidadas, ou que talvez ainda não haja uma identidade bastante estabelecida, pelo menos não dentro dos eventos e períodos considerados. Essa sobreposição é agravada pelos interesses semelhantes que as ênfases têm, pelas suas concepções de educação em sintonia e pelas temáticas trabalhadas que se aproximam, como a biológica e a ambiental.

Optamos, assim, por reunir os trabalhos voltados para as ênfases Questões Sociocientíficas, Questões Controversas e Questões Socioambientais dentro de uma nova categoria intitulada Questões.

Consideramos, em um primeiro momento, as sobreposições entre essas categorias, na tentativa de obter um panorama mais detalhado da amostra inicial de trabalhos. Essas sobreposições, porém, foram desconsideradas nos recortes subsequentes de análises. 
Tivemos, finalmente, uma quarta categoria para incluir os trabalhos que não faziam menção a nenhuma dessas ênfases, denominada Não Aplicável, pesquisas que estavam mais relacionadas a abordagens como a Natureza da Ciência, Ecologia e cidadania de maneira mais ampla, não associadas com as ênfases identificadas.

As categorias finais para este aspecto são, portanto, Alfabetização Científica, CTS(A), Questões e Não Aplicável.

O terceiro aspecto se volta para a Temática do Trabalho, isto é, a qual conteúdo curricular é abordado. Para melhor identificar as peculiaridades das Ênfases Adotadas, bem como facilitar futuras sistematizações, optamos por não considerar nem o tema específico, nem o tema em sua dimensão mais ampla, mas sim o ramo da Ciência a que o trabalho se destina. Assim, um trabalho sobre Dinâmica não foi considerado nem com esse tema específico, nem com o tema Mecânica, mas sim como Física, ramo da Ciência a que está direcionado. Temos, assim, inicialmente, três categorias: Física, Química e Biologia.

Muitos dos trabalhos encontrados, contudo, não se restringem a um tema de Química, Física ou Biologia, isto é, buscam uma interdisciplinaridade. Esta abordagem, assim como a transdisciplinaridade e a multidisciplinaridade, recebem inúmeras reflexões dentro da Pesquisa em Ensino de Ciências, sendo necessário um grande aprofundamento nesta área para uma compreensão mais rica e significativa para esta pesquisa. A impossibilidade desse aprofundamento, porém, não pode implicar uma simples rejeição ou desprezo dessas abordagens.

Para considerar a articulação de mais de uma disciplina, optamos por diferenciar os trabalhos segundo seus níveis de ensino. Incluímos, assim, aqueles que diziam respeito ao Ensino Infantil (E. I.) e ao Ensino Fundamental (E. F.) dentro da categoria Ciências (E. I. e E. F.). Esta escolha se justifica pelo fato destes níveis de ensino terem como ponto de partida a disciplina de Ciências, sem compromisso inicial com a disciplinaridade.

Para os trabalhos dos outros níveis de ensino, incluímos aqueles que se voltavam exclusivamente para um dos ramos da Ciência em sua respectiva categoria. Isto é, uma pesquisa que versava somente sobre Física foi incluída na categoria de mesmo nome.

Os trabalhos que versavam sobre mais de um ramo da Ciência, isto é, sobre Física e Biologia, assim como os que partiam de temáticas essencialmente interdisciplinares, como temáticas ambientais, de poluição e de sustentabilidade, foram incluídos dentro da categoria Interdisciplinar. 
Usamos, também, uma categoria para englobar as pesquisas que não especificaram o ramo da Ciência a que se destinam, seja porque essa informação não aparece no corpus de nossa análise, seja porque este não é o fator mais relevante para esses trabalhos, como é o caso daqueles que realizam Revisões Bibliográficas e Reflexões Teóricas. Trabalhos deste tipo foram reunidos dentro da categoria Não Delimitado.

Temos, assim, para o terceiro aspecto, seis categorias: Física, Química, Biologia, Ciências (E. I. e E. F.), Interdisciplinar e Não Delimitado.

O quarto aspecto, intitulado Natureza dos Trabalhos, identifica a qual tarefa os trabalhos se propunham, isto é, se eles buscavam realizar uma Análise de Materiais, um Levantamento de Concepções, etc.

Para este aspecto, usamos uma categoria intitulada Análises para incluir as pesquisas de análises de materiais, como livros e documentos oficiais, assim como análises de aulas e atividades didáticas planejadas e aplicadas.

Uma segunda categoria, intitulada Levantamento de Concepções, tem o objetivo de reunir os trabalhos que buscavam averiguar quais as concepções que estudantes e professores dos diferentes níveis de ensino têm acerca de Ciências, Alfabetização Científica, ou outro tema relacionado à área de interesse.

Além dessas categorias, usamos também uma para identificar as Propostas Didáticas, outra para as Reflexões Teóricas e uma para as Revisões Bibliográficas.

Visto que essas categorias não são excludentes, optamos por incluir um mesmo trabalho em mais de uma delas, quando julgamos necessário. Contudo, optamos por tornar as categorias referentes à Reflexão Teórica e Revisão Bibliográfica como exclusivas, isto é, uma pesquisa não pode pertencer a uma delas e a outra, como a de Análises.

Este cuidado é necessário porque qualquer trabalho mais amplo precisa passar por estas etapas, sendo elas um pré-requisito básico. Uma pesquisa que se dedica a uma Reflexão Teórica e a uma Análise de Aulas, por exemplo, de fato se dedica a uma Análise de Aulas, pois a reflexão teórica é apenas uma etapa dentro de algo maior, e não seu objetivo principal.

As categorias deste aspecto foram, portanto, Análises, Levantamento de Concepções, Proposta Didática, Reflexão Teórica e Revisão Bibliográfica.

O quinto aspecto, finalmente, diz respeito à Relação do Trabalho com a Sala de Aula, contando com categorias tanto que evidenciam o tipo de relação dos trabalhos com a realidade docente, quanto o nível de ensino a que se destinam. 
Uma primeira categoria, denominada Não diretamente relacionada com a sala de aula, inclui as pesquisas de cunho não prático, como reflexões teóricas e revisões bibliográficas. Uma segunda categoria intitulada Relacionada mas não especificado compreende os trabalhos que estão relacionados com a prática em sala de aula, mas que não fazem menção a qual nível de ensino se destinam no corpus de nossa análise.

São vários os níveis de ensino e as situações em que ocorrem o processo ensinoaprendizagem, como a Educação Infantil, o Ensino Fundamental, dividido em Anos Iniciais e Finais, o Ensino Médio, a Educação de Jovens e Adultos (EJA), o Ensino Técnico, o PréVestibular e o Ensino Superior, tanto em cursos de Licenciaturas, quanto em cursos de bacharelado e de outras naturezas.

Considerar esta grande segmentação dos níveis de ensino, embora desejável em um primeiro momento, acaba por dificultar a construção de recortes e classificações posteriores. Optamos, assim, por considerar vários desses níveis em conjunto, como a Educação Infantil e os dois níveis do Ensino Fundamental, que foram agrupados na categoria Ensino Infantil e Fundamental.

Cientes de que a EJA compreende, em especial, cursos de Ensino Médio, incorporamos aquela a esta categoria. O Ensino Pré-Vestibular também foi unido a esta categoria, visto que seus conteúdos e as idades de seus estudantes são semelhantes.

Optamos por incluir os trabalhos que se dedicam ao Ensino Superior em Licenciaturas a uma categoria de mesmo nome, pois consideramos que eles tenham peculiaridades que impeçam uma união sem perda significativa de riqueza de detalhes.

A Educação em Espaços não Formais não será considerada, pois, mesmo que essa modalidade de ensino tenha peculiaridades interessantes, foge do escopo de nossa pesquisa, que está interessada na formação para a cidadania e o papel dos professores nesse processo.

Os demais níveis de ensino, isto é, Ensino Superior excluindo Licenciaturas e Ensino Técnico, foram agrupadas na categoria Ensino Superior pois, mesmo que tenham suas diferenças, dizem repeito a níveis de ensino posteriores ao Ensino Médio, buscando uma formação para determinada profissão.

As categorias finais para este aspecto são Não diretamente relacionada com a sala de aula, Relacionada mas não especificado, Ensino Infantil e Fundamental, Ensino Médio, Ensino Superior em Licenciatura e Ensino Superior. 
A tabela 4, a seguir, apresenta os aspectos e suas respectivas categorias detalhados anteriormente:

Tabela 4 - Aspectos e categorias da primeira análise

\begin{tabular}{|c|c|c|c|c|}
\hline $\begin{array}{c}\text { Propósitos } \\
\text { Educacionais }\end{array}$ & $\begin{array}{l}\text { Ênfase } \\
\text { Adotada }\end{array}$ & $\begin{array}{c}\text { Temática do } \\
\text { Trabalho }\end{array}$ & $\begin{array}{c}\text { Natureza dos } \\
\text { Trabalhos }\end{array}$ & $\begin{array}{c}\text { Relação do Trabalho com } \\
\text { a Sala de Aula }\end{array}$ \\
\hline Percepções & $\begin{array}{c}\text { Alfabetização } \\
\text { Científica }\end{array}$ & Física & Análises & $\begin{array}{l}\text { Não diretamente relaci- } \\
\text { onada com a sala de aula }\end{array}$ \\
\hline Questionamentos & $\mathrm{CTS}(\mathrm{A})$ & Química & $\begin{array}{l}\text { Levantamento } \\
\text { de Concepções }\end{array}$ & $\begin{array}{l}\text { Relacionada mas não } \\
\text { especificado }\end{array}$ \\
\hline $\begin{array}{l}\text { Compromisso } \\
\text { Social }\end{array}$ & Questões & Biologia & $\begin{array}{l}\text { Proposta } \\
\text { Didática }\end{array}$ & $\begin{array}{l}\text { Ensino Infantil e } \\
\text { Fundamental }\end{array}$ \\
\hline \multirow[t]{3}{*}{ Não Aplicável } & $\begin{array}{c}\text { Não } \\
\text { Aplicável }\end{array}$ & $\begin{array}{l}\text { Ciências } \\
\text { (E. I. e E. F.) }\end{array}$ & $\begin{array}{c}\text { Reflexão } \\
\text { Teórica }\end{array}$ & Ensino Médio \\
\hline & & Interdisciplinar & $\begin{array}{c}\text { Revisão } \\
\text { Bibliográfica }\end{array}$ & $\begin{array}{l}\text { Ensino Superior em } \\
\text { Licenciaturas }\end{array}$ \\
\hline & & $\begin{array}{c}\text { Não } \\
\text { Delimitado }\end{array}$ & & Ensino Superior \\
\hline
\end{tabular}

Fonte: Bondezan (2019).

Estes serão, assim, os aspectos e as categorias que guiarão nossa primeira análise nas três edições do ENPEC selecionadas, evento escolhido como representativo da área de Pesquisa em Ensino de Ciências voltada para a cidadania.

Esta primeira análise busca traçar um panorama da área, identificando seus principais encaminhamentos, sendo seus resultados apresentados e discutidos no capítulo seguinte.

\subsection{Segunda análise: Fatores influenciadores da prática em sala de aula}

A segunda análise realizada tem como objetivo estudar os modos como os trabalhos da Pesquisa em Ensino de Ciências preocupados com a cidadania se concretizam na prática, identificando os principais fatores que influenciam as atividades desenvolvidas nas salas de aula.

A compreensão destes fatores se faz necessária na medida em que se deseja a realização de um diálogo com os professores em exercício, isto é, se deseja aproximar as contribuições dos pesquisadores da Pesquisa em Ensino de Ciências com os docentes em 
exercício, auxiliando-os no desenvolvimento de suas atividades didáticas, sem ignorar o contexto em que estão inseridos e suas visões individuais de educação.

Para a primeira análise selecionamos todos os trabalhos do IX, X e XI ENPEC dentro da linha temática denominada “Alfabetização científica e tecnológica, abordagens CTS e CTSA e educação em ciências”, assim como aqueles que apresentavam como palavras-chave os nomes das ênfases de interesse e expressões como "cidadania”, “controvérsias” e "socioambiental”.

Para a segunda análise, realizamos um recorte da amostra da primeira, selecionando apenas as pesquisas publicadas nas duas últimas edições do ENPEC (2015 e 2017) que possuíam uma relação direta com a sala de aula, se voltando para o Ensino Médio ou para o Ensino Superior em Licenciatura. Além deste critério de seleção, selecionamos apenas os trabalhos que descreviam com alguma riqueza de detalhes as atividades desenvolvidas. Foram 16 as pesquisas que preencheram todos esses critérios, sendo apresentadas na tabela 5, a seguir, e sendo referenciadas apenas com seus respectivos números nas demais tabelas deste trabalho.

Tabela 5 - Trabalhos selecionados para a segunda análise $e^{27}$

\begin{tabular}{ccc}
\hline Citação & Título dos trabalhos & Autores \\
\hline $\begin{array}{c}\text { (1) Moura e } \\
\text { Comaru (2015) }\end{array}$ & $\begin{array}{c}\text { Pedagogia Histórico-Crítica e Arte sequencial: } \\
\text { Metodologias alternativas no ensino de ciências }\end{array}$ & $\begin{array}{c}\text { Celcino Neves Moura e Michele Waltz } \\
\text { Comaru }\end{array}$ \\
\hline $\begin{array}{c}\text { (2) Freitas et al. } \\
\text { (2015) }\end{array}$ & $\begin{array}{c}\text { Biodiesel como Tema Gerador no Processo de } \\
\text { Alfabetização Científica }\end{array}$ & $\begin{array}{c}\text { Kátya Regina de Freitas, Bruna Zacari } \\
\text { Pamplona, Lívia Suemy Ogata, Ronaldo da } \\
\text { Luz Silva }\end{array}$ \\
\hline $\begin{array}{c}\text { Investigando questões sociocientíficas na } \\
\text { (3) Vale, Souza }\end{array}$ & $\begin{array}{c}\text { Wemática Combustíveis fósseis e alternativos: } \\
\text { em quais contextos são discutidas as relações } \\
\text { CTS? }\end{array}$ & $\begin{array}{c}\text { Rodrigues de Souza e Ruth do Nascimento } \\
\text { Firme }\end{array}$ \\
\hline $\begin{array}{c}\text { (4) Souza e } \\
\text { Martins (2015) }\end{array}$ & $\begin{array}{c}\text { Uma proposta de ensino de Física utilizando a } \\
\text { elaboração de vídeos experimentos }\end{array}$ & $\begin{array}{c}\text { Flávio Antônio Martins Souza e Silvia } \\
\text { Martins. }\end{array}$ \\
\hline $\begin{array}{c}\text { (5) Nunes, } \\
\text { Lindemann e } \\
\text { Galiazzi (2015) }\end{array}$ & $\begin{array}{c}\text { Abordagem de Situação-Problema na sala de } \\
\text { aula de química: o ensino CTS contribuindo } \\
\text { para a percepção social }\end{array}$ & $\begin{array}{c}\text { Bruna Roman Nunes, Renata Hernandez } \\
\text { Lindemann e Maria do Carmo Galiazzi }\end{array}$ \\
\hline $\begin{array}{c}\text { (6) Carvalho, } \\
\text { Moreira e }\end{array}$ & $\begin{array}{c}\text { Avaliação de estudantes sobre uma sequência } \\
\text { de ensino de termodinâmica orientada por uma } \\
\text { Aguiar Jr (2015) }\end{array}$ & $\begin{array}{c}\text { Alfredo Melk Carvalho, Adelson Fernandes } \\
\text { Moreira e Orlando Aguiar Júnior. }\end{array}$ \\
\hline
\end{tabular}

27 A tabela 28, em anexo, complementa a tabela 5, apresentando os Propósitos Educacionais e as Ênfases dos trabalhos selecionados para a segunda análise, isto é, sua classificação a respeito de dois dos aspectos da primeira análise. 


\begin{tabular}{|c|c|c|}
\hline Citação & Título dos trabalhos & Autores \\
\hline $\begin{array}{l}\text { (7) Cardoso et } \\
\text { al. (2015) }\end{array}$ & $\begin{array}{l}\text { Radioatividade e CTS: Resultados de uma } \\
\text { implementação }\end{array}$ & $\begin{array}{c}\text { Zaira Zangrando Cardoso; Rosana Oliveira } \\
\text { Dantas de Abreu; Roseline Beatriz Strieder; } \\
\text { Shirley Margareth Buffon da Silva; } \\
\text { Wildson Luiz Pereira dos Santos }\end{array}$ \\
\hline $\begin{array}{l}\text { (8) Martins, } \\
\text { Ribeiro e Ayres } \\
\text { (2017) }\end{array}$ & $\begin{array}{l}\text { A Alfabetização Científica a partir da } \\
\text { experimentação no ensino de lentes esféricas: } \\
\text { possibilidades e limitações }\end{array}$ & $\begin{array}{c}\text { Thalissa Gabriela Gurjão Martins, Erick } \\
\text { Elisson Hosana Ribeiro e Ayreson dos } \\
\text { Santos Ayres }\end{array}$ \\
\hline $\begin{array}{l}\text { (9) Batista, Assis } \\
\text { e Travain (2017) }\end{array}$ & $\begin{array}{l}\text { Efeito fotoelétrico - Uma abordagem } \\
\text { experimental para o Ensino de Física Moderna }\end{array}$ & $\begin{array}{c}\text { Karine de Cássia Prado Batista, Alice Assis } \\
\text { e Silmar Antonio Travain }\end{array}$ \\
\hline $\begin{array}{l}(10) \text { Terra e } \\
\text { Leite (2017) }\end{array}$ & $\begin{array}{c}\text { Estudos culturais sobre a produção de vinagre } \\
\text { para articular saberes escolares, científicos e } \\
\text { populares: uma educação química com enfoque } \\
\text { CTS/CTSA }\end{array}$ & $\begin{array}{l}\text { Vilma Reis Terra e Sidnei Quezada } \\
\text { Meireles Leite }\end{array}$ \\
\hline $\begin{array}{l}\text { (11) Silva et al. } \\
\text { (2017) }\end{array}$ & $\begin{array}{l}\text { Abordagem CTSA: Remediação Ambiental } \\
\text { como tema problematizador }\end{array}$ & $\begin{array}{c}\text { Jéssica Caroline Pena Alves da Silva, } \\
\text { Dalton Thiago Silva Betega, Pedro } \\
\text { Miranda Junior e Amanda Cristina Teagno } \\
\text { Lopes Marques }\end{array}$ \\
\hline $\begin{array}{l}\text { (12) Santana, } \\
\text { Terra e Leite } \\
\quad(2017)\end{array}$ & $\begin{array}{c}\text { Do caldo de cana ao açúcar: estudo cultural } \\
\text { com enfoque CTS/CTSA na educação Química } \\
\text { interdisciplinar }\end{array}$ & $\begin{array}{l}\text { Raíza Carla Mattos Santana, Vilma Reis } \\
\text { Terra e Sidnei Quezada Meireles Leite }\end{array}$ \\
\hline $\begin{array}{l}\text { (13) Pereira et } \\
\text { al. (2017) }\end{array}$ & $\begin{array}{l}\text { O estudo da Energia com enfoque CTS, } \\
\text { fundamentado no documentário POWER }\end{array}$ & $\begin{array}{l}\text { Janinha Pereira, Alessandra Santa Clara da } \\
\text { Costa, Awdry Feisser Miquelin e Rosemari } \\
\text { Monteiro Castilho Foggiatto Silveira }\end{array}$ \\
\hline $\begin{array}{l}\text { (14) Martinez et } \\
\text { al. (2017) }\end{array}$ & $\begin{array}{l}\text { Experimentação problematizadora e as } \\
\text { concepções dos alunos sobre a utilização de } \\
\text { textos no ensino de Química }\end{array}$ & $\begin{array}{c}\text { Giovana Martinez, Guilherme Balestiero da } \\
\text { Silva, Siomara Miranda dos Santos Correa, } \\
\text { Vera Aparecida de Oliveira Tiera e Jackson } \\
\text { Gois }\end{array}$ \\
\hline $\begin{array}{l}\text { (15) Santos et al. } \\
\text { (2017) }\end{array}$ & $\begin{array}{c}\text { Saberes escolares, científicos e populares a } \\
\text { partir de um estudo sobre a influência da } \\
\text { concentração de metais no crescimento de } \\
\text { raízes de batata doce }\end{array}$ & $\begin{array}{c}\text { Amanda de Oliveira Souza Santos, Maria } \\
\text { de Fátima Fontes Lelis, Julia Raquel } \\
\text { Peterle Pereira e Sidnei Quezada Meireles } \\
\text { Leite }\end{array}$ \\
\hline $\begin{array}{l}\text { (16) Fadini e } \\
\text { Leite (2017) }\end{array}$ & $\begin{array}{c}\text { Uma Pedagogia Histórico-Crítica para discutir } \\
\text { Educação Alimentar: Aspectos metodológicos } \\
\text { num Projeto Escolar de Ensino Médio }\end{array}$ & $\begin{array}{l}\text { Guilherme Pizoni Fadini e Sidnei Quezada } \\
\text { Meireles Leite }\end{array}$ \\
\hline
\end{tabular}
Fonte: Bondezan (2019).

Os sete primeiros trabalhos da tabela, publicados no X ENPEC, serviram de base para a construção dos eixos que foram, posteriormente, usados na análise de todos as 16 pesquisas. Estes eixos, assim como suas respectivas categorias e parte de seu processo de criação, serão mencionados e descritos detalhadamente no capítulo 6. Estes eixos têm como objetivo identificar como a cidadania foi colocada em prática nas atividades relatadas, considerando aspectos sobre as atividades desempenhadas pelos alunos, os conceitos científicos trabalhados em sala e o contexto em que a prática docente está inserida. 
Sobre a amostra da segunda análise, vale a pena mencionar que os trabalhos de número 10, 12, 15 e 16 têm o autor Sidnei Quezada Meireles Leite em comum e possuem várias semelhanças entre si. Este fato, que pode acabar influenciando de alguma maneira nossos resultados, não nos levou a descartar estas pesquisas, já que possuem algumas diferenças de encaminhamento entre si e já que sua presença não impactará negativamente a análise. 


\section{Capítulo 5 - Tendências da Pesquisa em Ensino de Ciências voltada à cidadania}

Como indicador das tendências da cidadania no Ensino de Ciências, elegemos como objeto de análise o Encontro Nacional de Pesquisa em Educação em Ciências, em suas edições de 2013, 2015 e 2017 (IX, X e XI). Selecionamos, neste evento, os trabalhos que estavam dentro da área temática denominada “Alfabetização científica e tecnológica, abordagens CTS e CTSA e educação em ciências”, bem como aqueles que apresentavam como palavras-chave os nomes das ênfases de interesse e expressões como “cidadania”, “controvérsias” e “socioambiental”, num total de 343 pesquisas.

Esta análise tem como objetivo identificar cinco aspectos, isto é, os Propósitos Educacionais dos trabalhos, a Ênfase adotada, a Temática do Trabalho, a Natureza dos Trabalhos e a Relação do Trabalho com a sala de Aula. A identificação destes aspectos, assim como das suas inter-relações, pretende apontar para eventuais aproximações entre eles.

Estas aproximações não devem ser entendidas como deterministas ou como afirmações de que uma abordagem implica certo posicionamento, mas sim como uma eventual existência de aproximações e afinidades das ênfases com determinadas etapas da escolarização, Propósitos Educacionais, etc.

A escolha do ENPEC se justifica pela sua abrangência a toda a área de Pesquisa em Ensino de Ciências, incluindo trabalhos das diversas disciplinas e com diferentes abordagens. Mesmo que estas abordagens compareçam com quantidades distintas, acreditamos que este evento possa fornecer um panorama bastante geral das ênfases voltadas ao incentivo de práticas cidadãs.

O aspecto Ênfases dos Trabalhos identifica as ênfases às quais os trabalhos fazem menção em seus títulos, resumos e palavras-chave, possuindo como categorias não exclusivas Alfabetização Científica, CTS(A), Questões e Não Aplicável. Foram consideradas aqui, inicialmente, as sobreposições entre as categorias, e foram reunidas as ênfases Questões Sociocientíficas, Controversas e Socioambientais dentro da categoria Questões. 
A figura 2, a seguir, mostra a quantidade de trabalhos encontrados em cada uma das categorias, assim como nas sobreposições: ${ }^{28}$

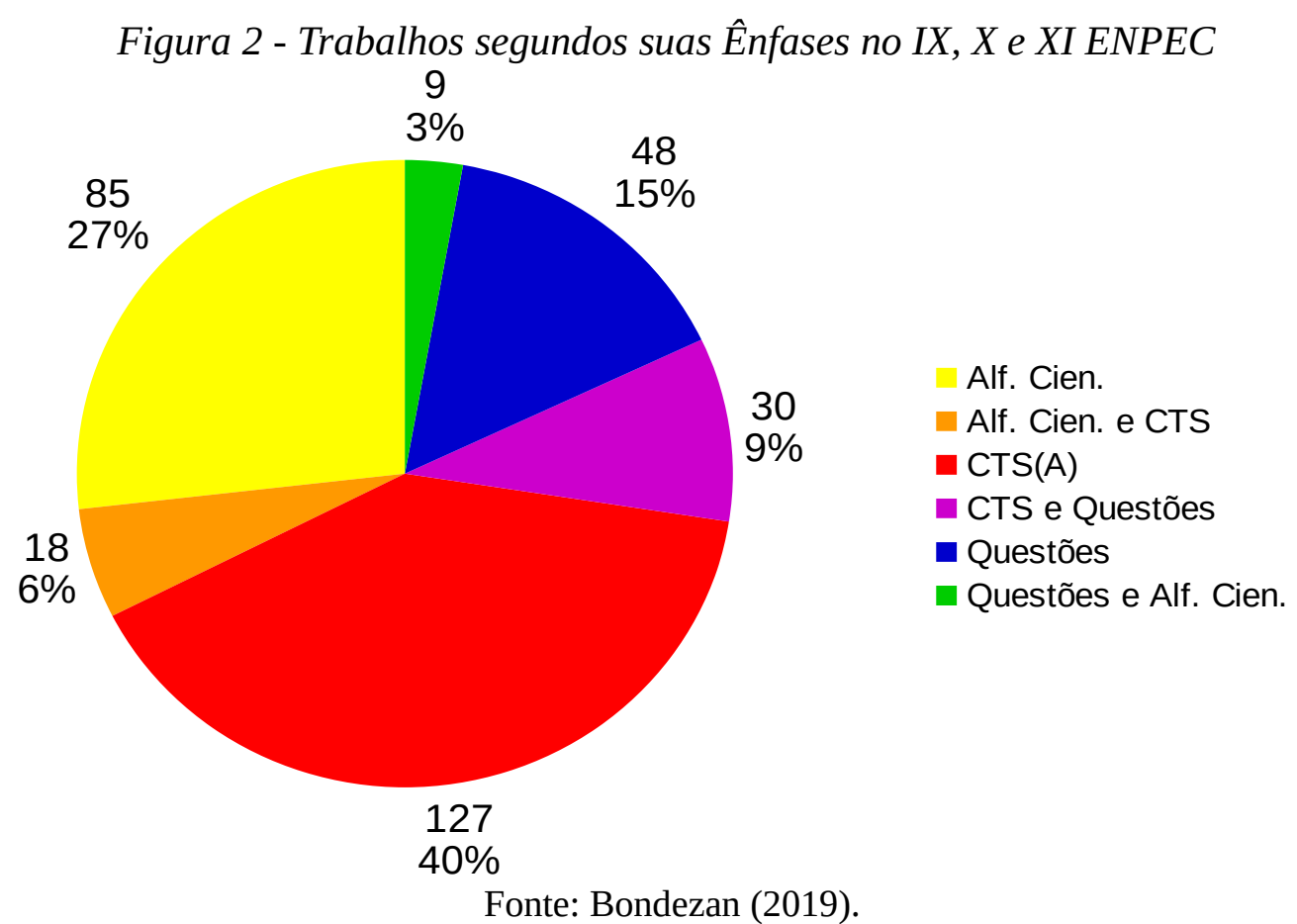

Embora a quantidade de trabalhos CTS seja consideravelmente maior que os de Alfabetização Científica e Questões, estes também aparecem com números expressivos. A união das Questões Sociocientíficas, Controversas e Socioambientais, permitiu que a quantidade de trabalhos que contém mais de uma ênfase fosse reduzido, mostrando uma pequena sobreposição e uma grande consolidação dessas três ênfases.

Essas sobreposições foram consideradas apenas num primeiro momento, sendo desconsideradas nos recortes da amostra, pois produziriam uma fragmentação excessiva, dificultando as etapas posteriores da análise.

22 foram os trabalhos classificados dentro da categoria Não Aplicável, não fazendo menção a nenhuma das expressões identificadas, se dedicando a abordagens ambientais, de natureza da ciência ou de cidadania de forma mais ampla.

28 Resultados parciais da análise aqui apresentada foram publicados em Bondezan e Kawamura (2018) e Bondezan e Kawamura (2019). Os critérios de análise, assim como os eixos e as categorias usadas foram os mesmos para esses dois trabalhos e para a presente pesquisa, mas as amostras foram distintas. No primeiro trabalhos foram analisados com critérios idênticos aos aqui descritos os trabalhos publicados no X ENPEC (2015), e, no segundo, foram analisados os trabalhos do IX, X e XI ENPEC (2013, 2015 e 2017) dentro da seção "Alfabetização Científica e tecnológica, abordagens CTS/CTSA e Educação em Ciências”. 
O aspecto Propósitos Educacionais identifica a quais propósitos os trabalhos se dedicavam, tendo como base as contribuições de Strieder (2012) e Strieder e Kawamura (2017), como detalhado anteriormente. As categorias deste aspecto foram Percepções, Questionamentos, Compromisso Social e Não Aplicável, ficando dentro da última os trabalhos que não explicitavam no corpus de análise a quais propósitos se voltavam.

A figura 3, a seguir, apresenta a quantidade de pesquisas em cada uma das categorias:

Figura 3 - Propósitos Educacionais de todos os trabalhos do IX, X e XI ENPEC

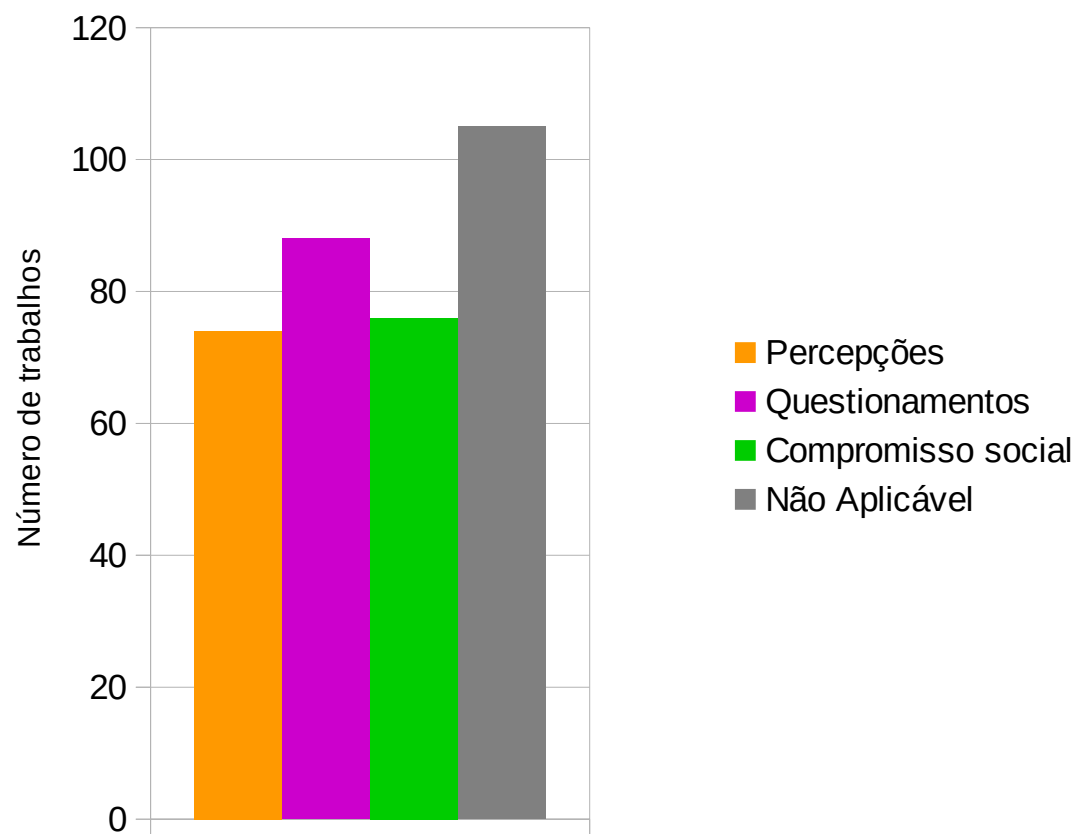

Fonte: Bondezan (2019).

Neste aspecto predominam as pesquisas dentro da categoria Não Aplicável, isto é, aqueles que não tiveram seus Propósitos Educacionais identificados. A não identificação desses propósitos ocorreu tanto porque os trabalhos não apresentaram informações que permitissem a sua classificação, quanto por se tratar de pesquisas de levantamento de concepções de alunos e de análise de materiais, isto é, pesquisas em que não se deseja promover um ou outro propósito, mas sim uma abordagem mais próxima da imparcialidade.

Dentro dos propósitos prevalecem os trabalhos que se voltam ao desenvolvimento de Questionamentos, ficando os outros dois propósitos em quantidade ligeiramente menor.

Essas informações indicam a existência de diferentes concepções de cidadania dentro das pesquisas encontradas, mas há a necessidade de uma maior complexificação dessa análise para que sejam identificadas mais características da amostra e compreenda-se melhor esta distribuição. 
Mais características da amostra podem ser levantadas com o auxílio dos aspectos “Temática do Trabalho”, "Natureza dos Trabalhos” e "Relação do Trabalho com a sala de Aula” e com a realização de recortes específicos.

A figura 4, a seguir, mostra os Propósitos Educacionais dos trabalhos dentro de cada uma das Ênfases, isto é, a Alfabetização Científica, a CTS(A) e as Questões:

Figura 4 - Propósitos Educacionais nas Ênfases Adotadas no IX, X e XI ENPEC

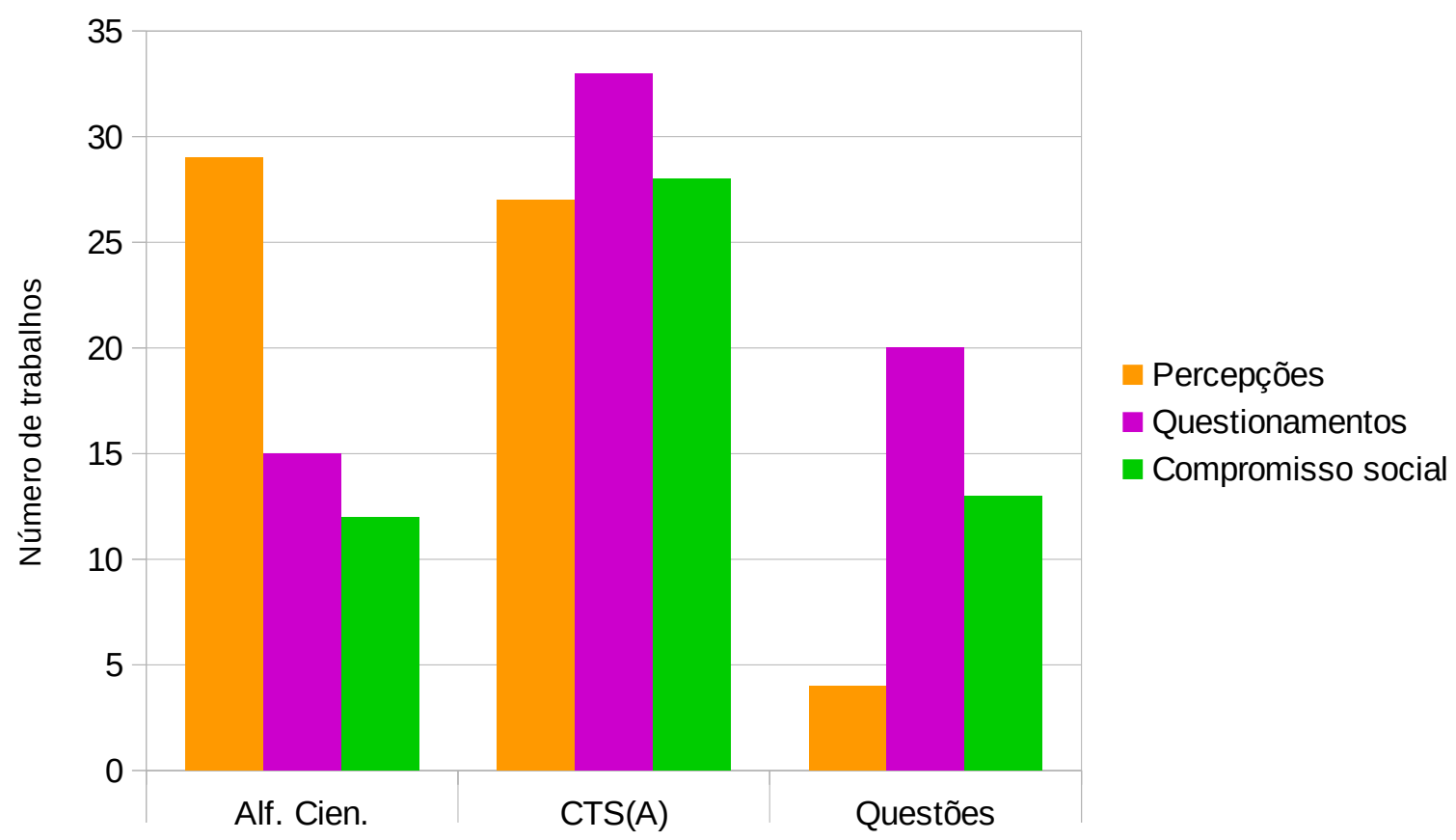

Fonte: Bondezan (2019).

Realizando o recorte dos trabalhos que se dedicam à ênfase “Alfabetização Científica”, temos um nítido destaque dos que se propõem a desenvolver Percepções, com os que se propõem ao desenvolvimento de Questionamentos e de Compromisso Social aparecendo com um número menor, mas ainda notável.

Dentro da ênfase CTS(A), apareceram em maior número os trabalhos que se propõem ao desenvolvimento de Questionamentos, com os outros dois propósitos aparecendo com quantidades muito próximas.

Finalmente, para as Questões, temos um grande destaque das abordagens que buscam Questionamentos, com as que visam um Compromisso Social aparecendo com quantidade ligeiramente menor. As abordagens que se propõem ao desenvolvimento de Percepções, por outro lado, aparecem com proporção bastante reduzida. 
As pesquisas que não tiveram seus Propósitos Educacionais identificados, num total de 105, ficaram ausentes deste gráfico pois dificultariam sua leitura e não alterariam os resultados.

A mesma amostra de trabalhos, isto é, os 343 publicados nos IX, X e XI ENPEC que cumpriram nossos critérios de seleção, pode ser analisada à luz do quarto aspecto, Naturezas dos Trabalhos. Este aspecto tem como objetivo identificar se os trabalhos se dedicam a realizar Análises, Levantamento de Concepções, Reflexão Teórica, Revisão Bibliográfica ou uma Proposta Didática. Vale a pena destacar que na primeira dessas categorias foram reunidas as pesquisas que analisaram livros, documentos oficiais e aulas aplicadas.

A figura 5, a seguir, mostra a quantidade de trabalhos em cada uma das categorias deste aspecto:

Figura 5 - Natureza dos trabalhos no IX, X e XI ENPEC

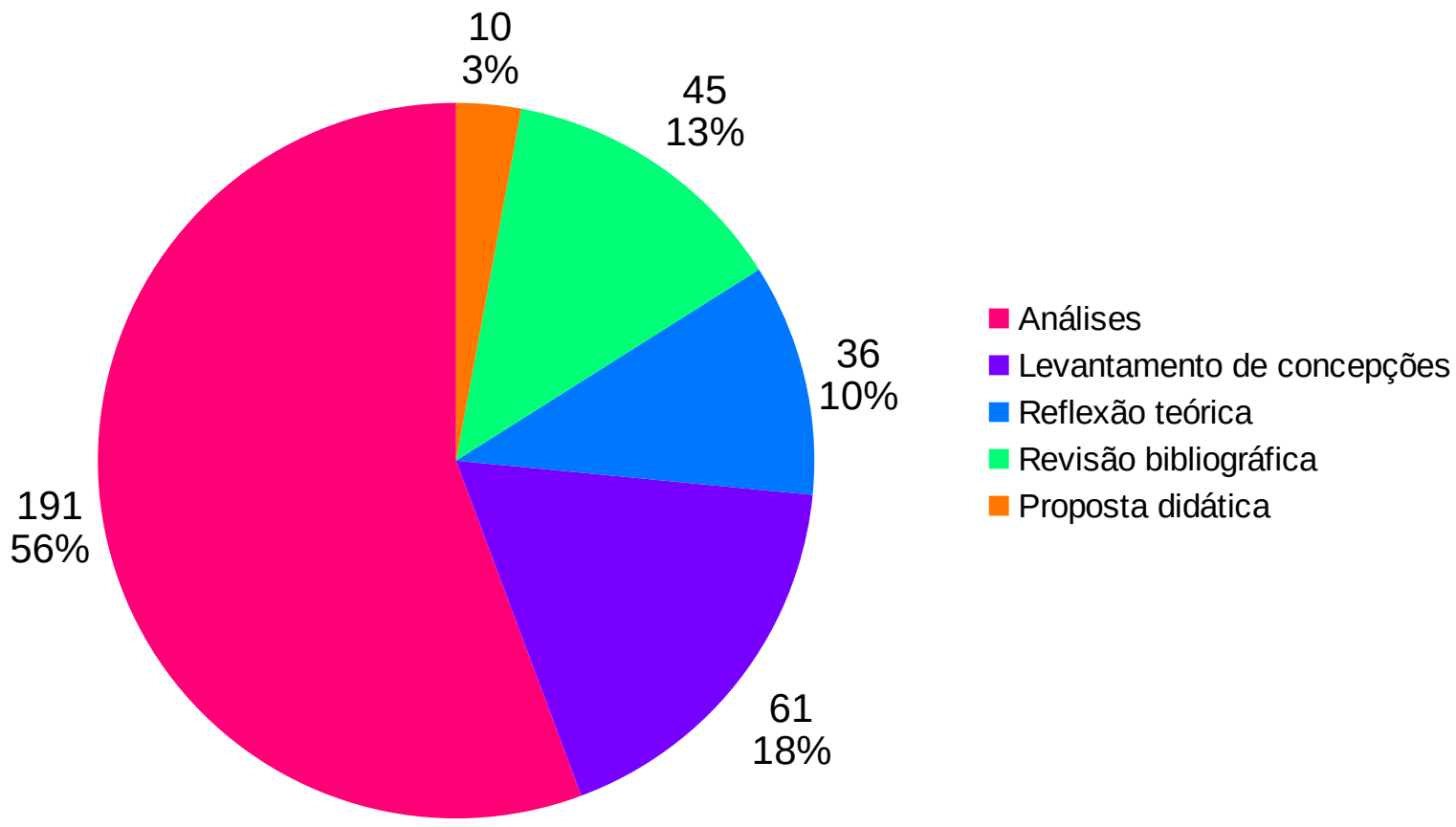

Fonte: Bondezan (2019).

Mais da metade dos trabalhos se dedica a realizar análises, tanto de livros e materiais, quanto de aulas aplicadas, enquanto os que se propõem a um Levantamento de Concepções compõem menos de um quinto da amostra. Os que se propõem a uma Reflexão Teórica e a uma Revisão Bibliográfica aparecem com números baixos mas expressivos, mesmo com suas categorias consideradas como exclusivas.

Finalmente, apenas 3\% da amostra apresentava uma Proposta Didática, baixa quantidade que se explica pelas características específicas do evento considerado, isto é, não 
são aceitos nele relatos de experiências e predominam as pesquisas contendo propostas didáticas aplicadas e analisadas.

A Natureza dos Trabalhos pode ser compreendida com mais detalhes quando é identificada dentro de cada uma das Ênfases, isto é, ao se averiguar separadamente qual a natureza dos trabalhos voltados a Alfabetização Científica, CTS(A) e Questões. A figura 6, a seguir, mostra o resultado da análise segundo este recorte:

Figura 6 - Ênfase adotada por Natureza dos trabalhos no IX, X e XI ENPEC

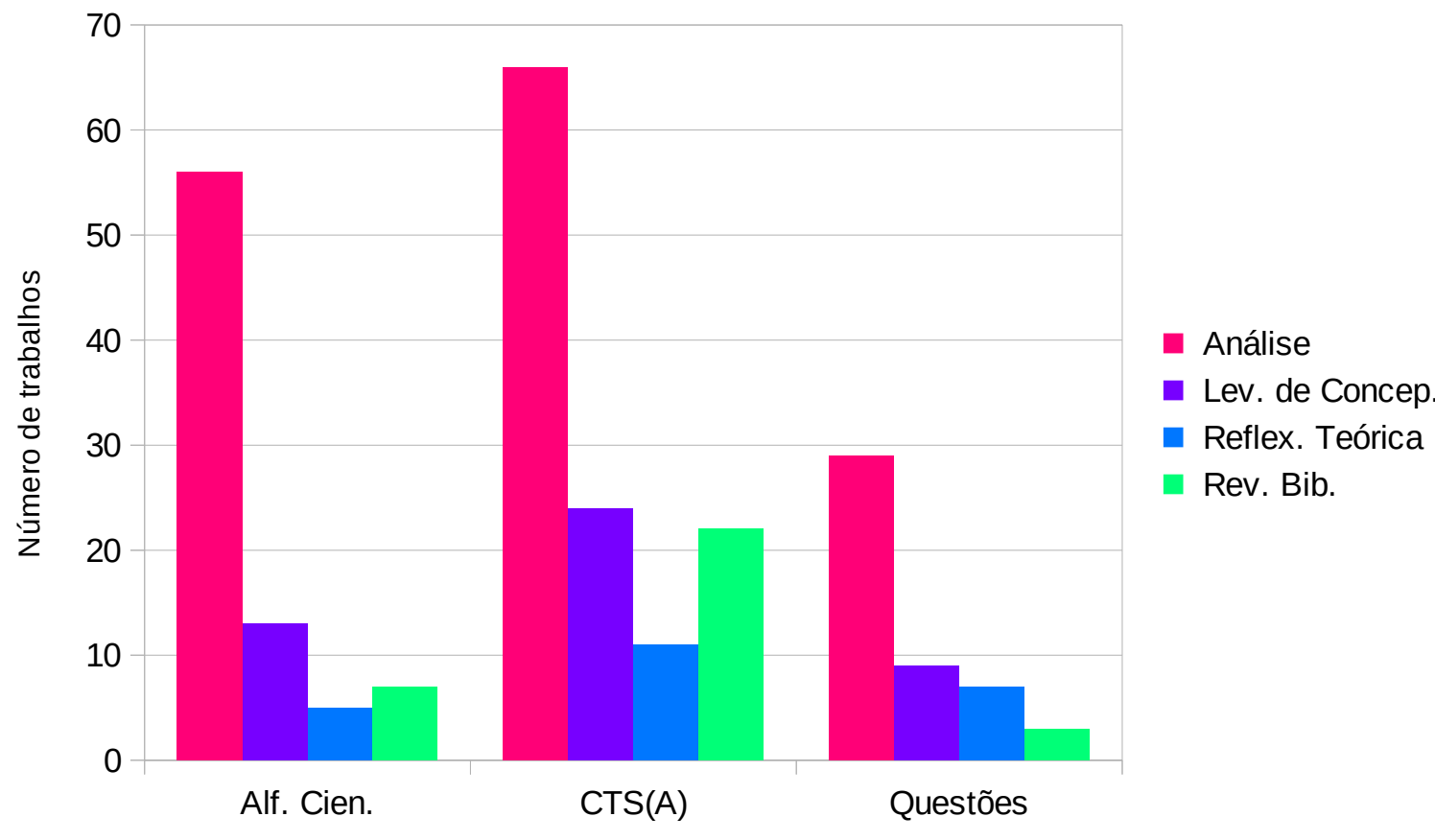

Fonte: Bondezan (2019).

Há um predomínio bastante nítido dos trabalhos que se destinam a realizar Análises em todas as três ênfases, mesmo sendo mais acentuado nas duas primeiras. Há, assim, uma grande quantidade de pesquisas que analisam livros e materiais didáticos, documentos oficiais e aulas aplicadas em todas as três ênfases.

Dentro da ênfase Alfabetização Científica temos, além do predomínio das Análises, quantidade considerável de trabalhos voltados ao Levantamento de Concepções, com as Reflexões Teóricas e as Revisões Bibliográficas aparecendo em menor número.

Dentro da ênfase CTS(A), os Levantamentos de Concepções e as Revisões Bibliográficas aparecem com quantidade bastante menor do que as Análises, mas com o dobro da quantidade de trabalhos voltados a realizar Reflexões Teóricas. 
Para as Questões, além do predomínio das Análises, aparecem com quantidade bastante próxima e cada vez menor os Levantamentos de Concepções, as Reflexões Teóricas e as Revisões bibliográficas.

Não é possível inferir ao certo os motivos que levam a esta distribuição, mas talvez ela possa ser explicada pelo estágio de desenvolvimento dessas ênfases. Numa ênfase bastante estabelecida, talvez seja prioridade dedicar esforços para propor atividades novas e as analisar, levantar as concepções que alunos professores e demais pessoas têm de determinado assunto e revisar a produção bibliográfica da área. Numa ênfase consolidada, por outro lado, talvez não seja prioridade realizar reflexões teóricas, pois já existe uma produção teórica bastante grande. Este parece ser o caso das ênfases Alfabetização Científica e CTS(A).

As Questões, por outro lado, apresentam uma quantidade muito pequena de revisões bibliográficas e uma quantidade um pouco maior de reflexões teóricas, o que indicaria uma necessidade de se delinear os rumos desta ênfase, rumos que ainda não estão suficientemente traçados.

Vale a pena mencionar, finalmente, que as pesquisas que apresentaram Propostas didáticas, num total de 10, compunham cerca de 3\% da amostra e foram omitidas da figura 6.

Pode ser identificada, em nossa amostra, também, qual a Relação com a Sala de Aula dos trabalhos. Este aspecto tem como objetivo diferenciar as pesquisas não diretamente relacionadas com a sala de aula e os níveis de ensino que eram objeto de estudo das que tinham relação direta com a sala de aula. Faz parte deste aspecto as categorias Não diretamente relacionada com a sala de aula, Relacionada mas não especificada, Ensino Infantil e Fundamental, Ensino Médio, Ensino Superior em Licenciaturas e Ensino Superior. A quantidade de trabalhos em cada categoria e a proporção que possuem no total da amostra está na tabela 6, a seguir:

Tabela 6 - Relação com a Sala de Aula e nível de ensino no IX, X e XI ENPEC

\begin{tabular}{lcc}
\hline \multicolumn{1}{c}{ Categoria } & Quantidade & Proporção (\%) \\
\hline Não diretamente relacionada com a sala de aula & 119 & 33 \\
\hline Relacionada mas não especificado & 13 & 4 \\
\hline Ensino Infantil e Fundamental & 48 & 13 \\
\hline Ensino Médio & 75 & 21 \\
\hline Ensino Superior em Licenciaturas & 71 & 20 \\
\hline Ensino Superior & 19 & 5 \\
\hline
\end{tabular}

Fonte: Bondezan (2019). 
Um terço dos trabalhos não está diretamente relacionado com a sala de aula. Entre os que possuem relação direta com a sala de aula, temos uma quantidade grande e bastante próxima dos voltados ao Ensino Médio e ao Ensino Superior em Licenciaturas, contextos que parecem ser os principais ambientes de estudo dos pesquisadores da área. Com quantidade um tanto menor aparecem os trabalhos voltados ao Ensino Infantil e Fundamental e com quantidade ainda menor, os voltados ao Ensino Superior em cursos não voltados à formação de professores.

As categorias deste aspecto voltadas a identificar os níveis de ensino das pesquisas podem ser combinadas com as Ênfases, ou seja, pode-se quantificar quantos trabalhos se voltavam para o Ensino Infantil e Fundamental e buscavam promover uma Alfabetização Científica, assim como os de outros níveis de ensino e as outras ênfases. Os resultados obtidos com o uso deste recorte estão na figura 7:

Figura 7 - Ênfase por Nível de Ensino no IX, X e XI ENPEC

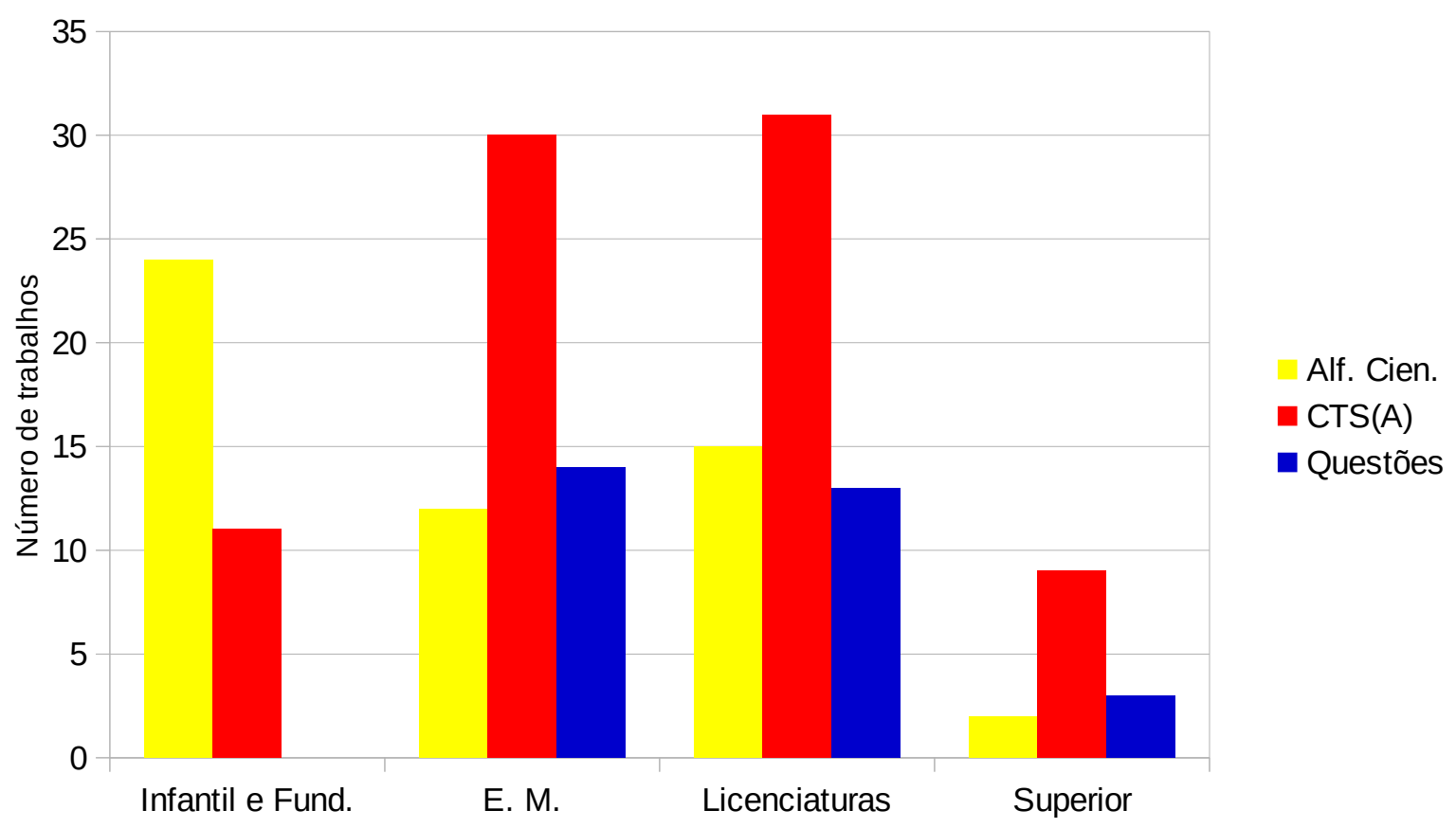

Fonte: Bondezan (2019).

Considerando-se os níveis Infantil e Fundamental, há um grande destaque da ênfase Alfabetização Científica, com a CTS(A) aparecendo com menos da metade do número de trabalhos da primeira ênfase. Há, também, a ausência de pesquisas voltadas às Questões.

Para o Ensino Médio, temos um destaque bastante nítido da ênfase CTS(A), com as outras duas próximas de um empate e com menos da metade do número das pesquisas daquela ênfase. 
Uma distribuição bastante semelhante pode ser observada no Ensino Superior em Licenciaturas e no Ensino Superior, com apenas uma pequena diferença nas quantidades de trabalhos voltados às Questões e às Alfabetizações Científicas.

Estes dados nos indicam que existe uma maior afinidade da ênfase Alfabetização Científica com os níveis Infantil e Fundamental, mesmo que ela esteja presente, também, nos outros níveis de escolarização.

No que diz respeito à ênfase CTS(A) e às Questões, não é possível afirmar que exista uma afinidade específica com algum dos níveis de ensino, mas parece haver uma afinidade destas ênfases com o Ensino Médio e com os outros níveis posteriores.

Os níveis de ensino podem ser identificados de maneira combinada com os Propósitos Educacionais dos trabalhos, isto é, pode-se contabilizar, por exemplo, quantos deles desenvolviam Percepções e se voltavam para o Ensino Fundamental. A figura 8 apresenta os dados deste recorte:

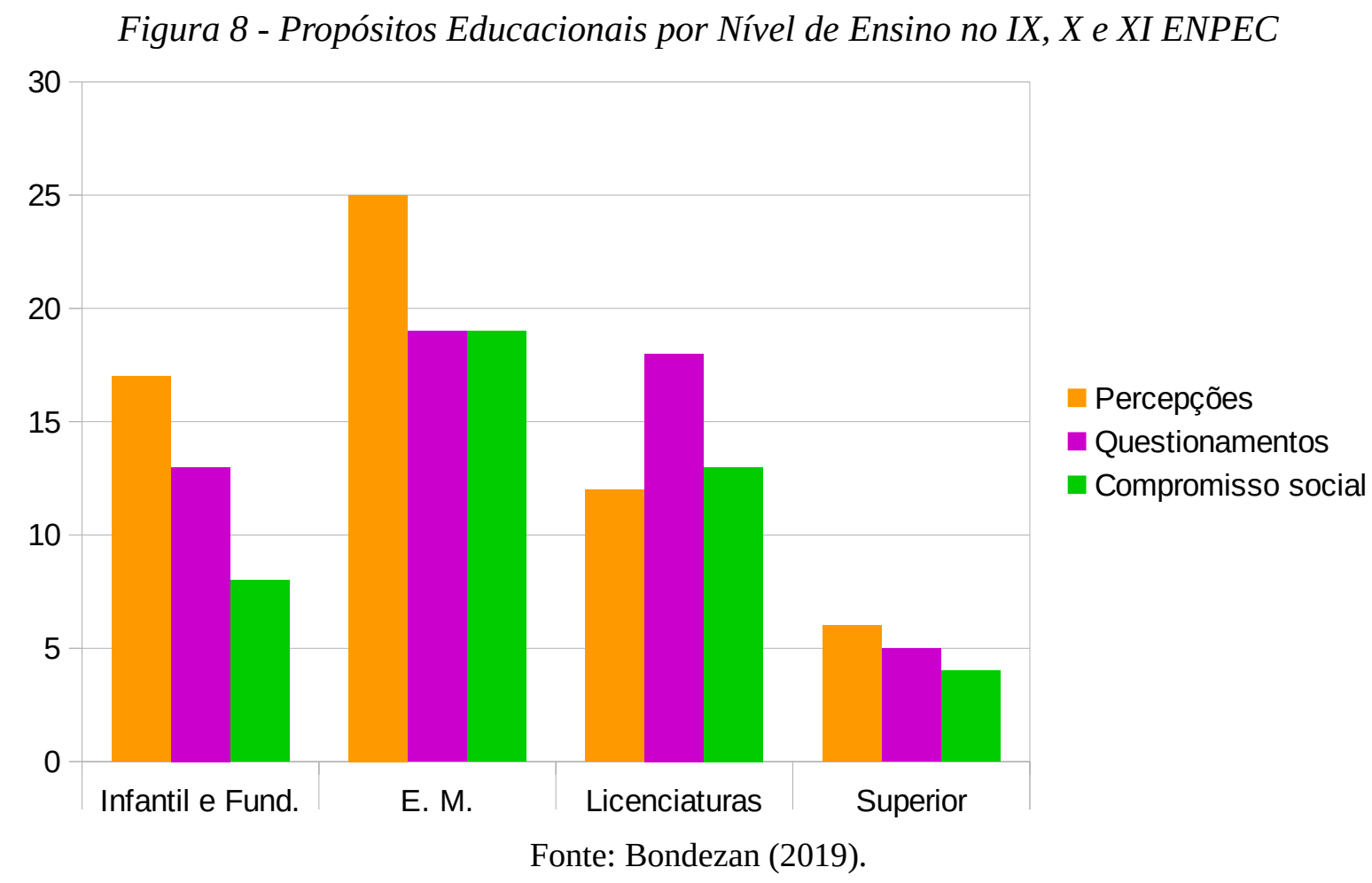

Para os níveis Infantil e Fundamental, temos predomínio do desenvolvimento de Percepções, com os Questionamentos aparecendo com quantidade menor e o Compromisso Social com quantidade ainda menor.

Para o Ensino Médio temos, novamente, um predomínio das Percepções, com os outros dois propósitos empatados e com quantidades bastante expressivas. 
Nas Licenciaturas, por outro lado, há um predomínio dos Questionamentos, com os outros dois propósitos educacionais aparecendo com quantidades semelhantes e menores do que o primeiro.

Finalmente, para o Ensino Superior, temos, novamente, um predomínio das Percepções, com as quantidades de trabalhos dos outros propósitos ficando bastante próximas.

Estes dados indicam que há uma tendência de se incentivar posturas mais individuais e passivas no Ensino Infantil e Fundamental, tendência que muda, de alguma forma, nos níveis mais avançados de escolarização. Se no Ensino Médio não podemos dizer que exista uma modificação na cidadania incentivada quando comparada ao Ensino Infantil e Fundamental, nas Licenciaturas há um claro domínio dos Questionamentos, apontando para um maior incentivo de posturas mais críticas e ativas.

A amostra de trabalhos publicada no IX, X e XI ENPEC pode ser analisada segundo o aspecto Temática dos Trabalhos. Este aspecto tinha como objetivo identificar se as pesquisas tinham como foco as disciplinas de Física, Química e Biologia, a disciplina de Ciências do Ensino Fundamental, se havia a intenção de promover uma atividade interdisciplinar ou se não havia uma temática delimitada. Os resultados desta análise estão na tabela 7:

Tabela 7 - Quantidade de trabalhos por Temática no IX, X e XI ENPEC

\begin{tabular}{lcc}
\hline \multicolumn{1}{c}{ Categoria } & Quantidade & Proporção (\%) \\
\hline Física & 25 & 7 \\
\hline Química & 43 & 13 \\
\hline Biologia & 41 & 12 \\
\hline Não Delimitado & 93 & 27 \\
\hline Interdisciplinar & 79 & 23 \\
\hline Ciências (E. I. e E. F.) & 62 & 18 \\
\hline
\end{tabular}

Fonte: Bondezan (2019).

Entre as disciplinas tradicionais, nossos dados indicam que os trabalhos de Química e de Biologia aparecem com quantidades semelhantes e nitidamente maiores que os de Física.

A maior parte das pesquisas, 27\%, não delimitava a qual ramo da ciência se dedicavam, seja porque esta informação não estava presente em nosso corpus de análise, seja porque realizavam Revisões Bibliográficas e Reflexões Teóricas, não sendo necessária uma delimitação da ciência abordada.

Quase um quarto das pesquisas se propõe a uma abordagem interdisciplinar. Assim, mesmo que fuja do escopo da atual pesquisa refletir quais as especificidades da 
interdisciplinaridade pretendida, assim como qualificar o sucesso ou insucesso em materializar esta abordagem, é inegável que ela tenha papel central na área de Pesquisa em Ensino de Ciências que visa a cidadania.

Por fim, $18 \%$ dos trabalhos se dedicavam às Ciências no Ensino Infantil e Fundamental. ${ }^{29}$

As Ênfases adotadas pelos trabalhos podem ser identificadas em conjunto com suas temáticas. A figura 9, a seguir, contém os dados a partir deste recorte:

Figura 9 - Ênfases por Temática dos trabalhos no IX, X e XI ENPEC

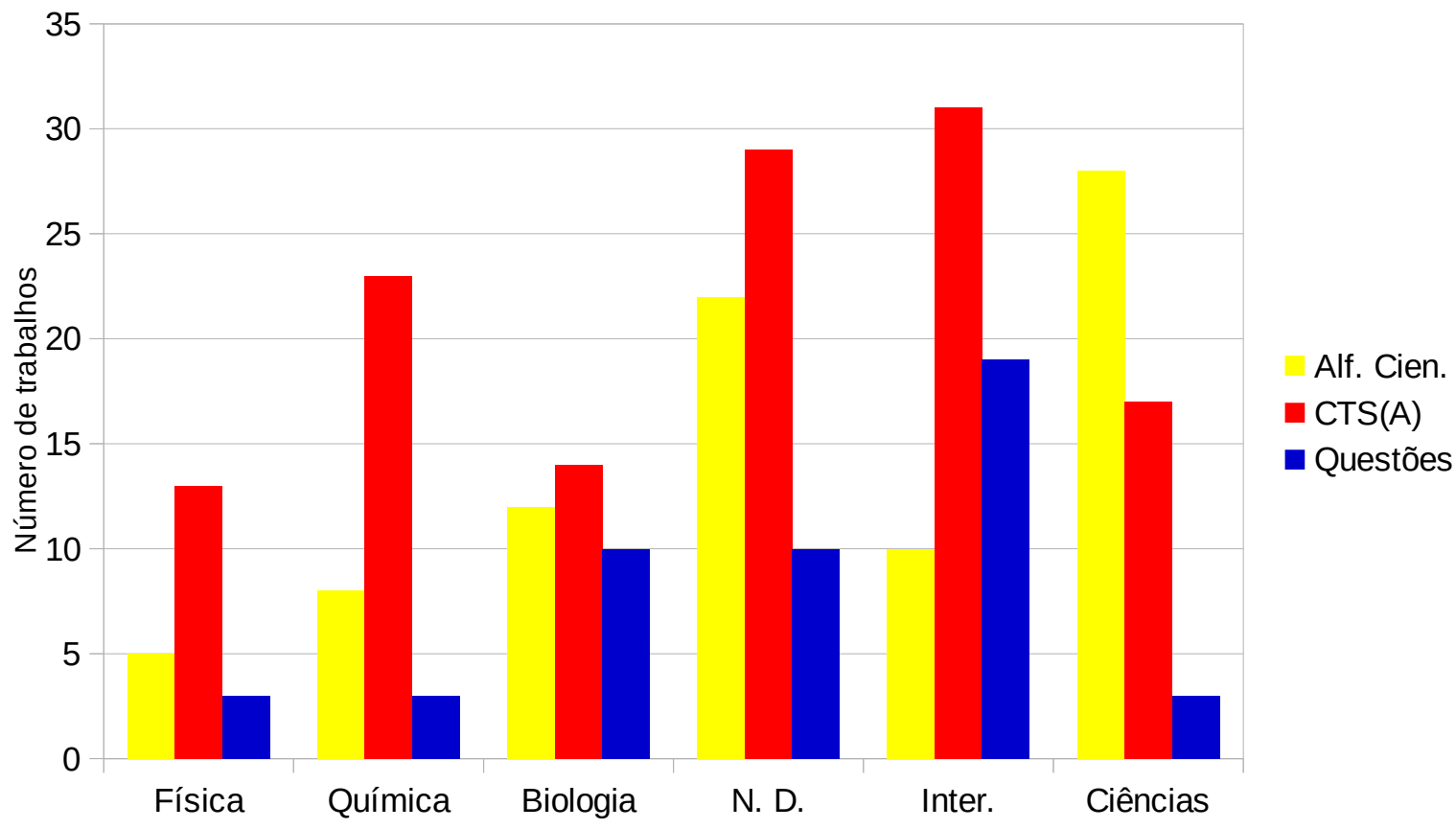

Fonte: Bondezan (2019).

Embora a ênfase CTS tenha aparecido com maior número em todas as temáticas, com a exceção das Ciências em Ensino Infantil e Fundamental, há algumas diferenças importantes:

Em primeiro lugar, é bastante nítido e destoante o predomínio das Alfabetizações Científicas nos trabalhos voltados às Ciências em Ensino Infantil e Fundamental, com a ênfase CTS(A) aparecendo em menor número e com a quase ausência das Questões. Estes dados vão na mesma direção dos apresentados pela figura 7 (página 85) sobre a afinidade da Alfabetização Científica com os níveis Infantil e Fundamental.

29 A comparação dos dados da tabela 6, na página 84, com os dados tabela 7 sugere uma inconsistência de resultados, já que há uma grande divergência no número de trabalhos voltados ao Ensino Infantil e Fundamental (48 ante 62). Vale a pena lembrar, contudo, que, na tabela 6, 48 eram os trabalhos que tinham relação direta com a sala de aula e com o Ensino Infantil e Fundamental e, na tabela 7,62 são as pesquisas que trabalham a temática Ciência, tanto de maneira prática, quanto de maneira indiretamente relacionada com a sala de aula. 
Em segundo lugar temos, dentro da categoria destinada às temáticas interdisciplinares, o número de trabalhos voltados às Questões sendo quase o dobro dos voltados à Alfabetização Científica. Esta distribuição um tanto destoante das outras temáticas pode indicar que as Questões têm bastante aptidão para temáticas Interdisciplinares, ou, de maneira inversa, que as abordagens interdisciplinares são um terreno fértil para colocar em prática as Questões.

Finalmente, em terceiro lugar, temos um quase equilíbrio entre as ênfases na temática Biologia.

A primeira análise, apresentada neste capítulo, contou com cinco aspectos e a realização de recortes específicos, tendo como objetivo a obtenção de um panorama da Pesquisa em Ensino de Ciências voltada à promoção da cidadania. Foram identificadas três ênfases com este fim: Alfabetização Científica, CTS(A) e Questões, assim como aproximações com níveis de ensino, Propósitos Educacionais, entre outros.

A partir deste panorama, realizamos uma segunda análise, a ser apresentada no capítulo seguinte, com intuito de identificar os principais aspectos influenciadores de atividades voltadas à promoção da cidadania em sala de aula. 


\section{Capítulo 6 - Principais influências das atividades didáticas voltadas à cidadania}

Para identificar as principais influências nas atividades realizadas em sala de aula voltadas à cidadania, assim como algumas de suas principais características, fizemos uma análise da produção da área da Pesquisa em Ensino de Ciências com este fim, cujos detalhes sobre a constituição da amostra foram anteriormente apresentados.

Reconhecer estas influências é importante para que se conheça as múltiplas possibilidades de encaminhamentos visando a cidadania, e para que seja possível a realização de escolhas conscientes por parte dos professores em exercício e demais profissionais associados ao Ensino de Ciências.

Esta análise, inicialmente, se debruçou sobre os trabalhos publicados no X ENPEC (2015) que, além de estarem vinculados às ênfases relacionadas à promoção da cidadania, se dedicavam ao Ensino Médio e ao Ensino Superior em Licenciaturas, descrevendo as atividades desenvolvidas com alguma riqueza de detalhes. Foram 7 as pesquisas que obedeceram estes critérios.

Esta amostra serviu de base para a construção dos eixos e das categorias que foram usadas, posteriormente, para analisar as pesquisas selecionadas com os mesmos critérios no X e XI ENPEC (2015 e 2017), num total de 16 trabalhos.

A identificação dos principais fatores que influenciam a prática docente voltada à cidadania, assim como os eixos e categorias usadas para a análise propriamente dita será detalhada na seção a seguir. Os resultados da análise dos trabalhos serão mostrados na seção 6.2, sendo as discussões sobre estes resultados e suas implicações para a cidadania objetos do capítulo seguinte.

\subsection{Identificação dos principais aspectos influenciadores das práticas em sala de aula}

Os principais fatores que influenciam a prática docente foram identificados a partir de sucessivas leituras dos 7 trabalhos do X ENPEC que compunham nossa amostra inicial da segunda análise. Nestas leituras, levantamos os pontos que se mostravam mais importantes 
para a prática em sala de aula preocupada com a cidadania, que foram reunidos em eixos. Estes eixos, que foram reprocessados e aperfeiçoados ao longo da análise, sempre tinham a preocupação de destacar a atividade docente, os conteúdos curriculares e as posturas que os alunos assumiam ao longo das aulas.

Os eixos finais, originários deste processo, englobam uma ampla gama de aspectos, como a abordagem do conhecimento científico, a dinâmica das aulas e o grau de engajamento dos alunos. Faz parte destes fatores, também, aspectos que aparentemente não possuem grande influência com a perspectiva de cidadania colocada em prática, mas que dizem respeito à realidade vivenciada pelos docentes em suas respectivas escolas e as possibilidades de ação dentro destes cenários.

Integram esses fatores, finalmente, as concepções de cidadania que os autores apresentam na introdução e em outros momentos do trabalho. Ainda que estas concepções possam estar limitadas à teoria e não tenham nenhuma relação com as atividades práticas desenvolvidas, elas são o ponto de partida dos autores e mostram a visão que eles possuem de educação e dos estudantes que pretendem formar.

Esta ampla gama de aspectos, originária da análise realizada, foi reunida na forma de sete eixos, apresentados na tabela 8 a seguir, e descritos posteriormente.

Tabela 8 - Eixos da segunda análise

\begin{tabular}{cr}
\hline Número do eixo & Nome do eixo \\
\hline I & Tema de Referência \\
\hline II & Relação do professor com o conhecimento científico \\
\hline III & Engajamento dos alunos \\
\hline IV & Atividades desenvolvidas em sala \\
\hline V & Participação na sociedade que os alunos desenvolvem \\
\hline VI & Contexto da prática docente \\
\hline VII & Cidadania apresentada pelos autores \\
\hline
\end{tabular}

O eixo I, intitulado “Tema de referência”, identifica a potencialidade que o tema científico escolhido para a atividade em sala possui para a cidadania. Esta potencialidade seria própria do tema, específica dele, o mais independente possível de qualquer encaminhamento metodológico posterior. 
A potencialidade de um tema para com a cidadania está associada com o recorte que é feito dos conteúdos científicos, isto é, um tema bastante restrito a um conceito curricular teria menor possibilidade para uma atividade visando a cidadania do que um tema bastante abrangente, que envolve diversos conceitos científicos de uma ou mais ciências.

O eixo II, denominado "Relação do professor com o conhecimento científico”, busca detalhar a origem do conhecimento científico trabalhado em sala de aula, isto é, quais são as motivações para seu estudo e quais os agentes educacionais que participaram da sua escolha e delimitação.

Identificar a origem do conhecimento científico trabalhado é importante porque um conhecimento escolhido e abordado com base no currículo escolar previamente estabelecido possui relação com a cidadania mais distante do que um conhecimento escolhido a partir do cotidiano dos estudantes.

O eixo III, intitulado "Engajamento dos alunos", se volta especificamente para os alunos e como eles reagem diante das aulas aplicadas, diferenciando atividades que não são capazes de motivar os alunos daquelas que conseguem sensibilizá-los e fazer com que participem ativamente.

Para a análise deste eixo, utilizamos as informações presentes nos trabalhos da maneira mais objetiva possível, julgando serem verdadeiros todos os relatos e percepções mencionados, mesmo que sejam dos próprios autores e, portanto, tendenciosos.

Tanto o eixo IV, quanto o $\mathrm{V}$ focam a dinâmica estabelecida dentro da sala de aula e demais espaços de aprendizagem, mas consideram as ações realizadas sob dois pontos de vista distintos:

O eixo IV diz respeito às “Atividades desenvolvidas em sala”, ou seja, às atividades que os alunos realizam no decorrer da proposta didática, dando especial atenção para sua postura passiva em aulas expositivas e sua criatividade e trabalho em equipe em aulas colaborativas e participativas. Este eixo está intimamente associado com as ações desempenhadas pelos estudantes em sala de aula, mas um tanto distante da relação que eles estabelecem com a sociedade de maneira mais ampla.

O eixo V, denominado "Participação na sociedade que os alunos desenvolvem”, também diz respeito à dinâmica da sala de aula e às atividades realizadas pelos alunos, mas, diferente do eixo IV, tem como foco a relação que estas atividades possuem com a cidadania propriamente dita. Dentro deste eixo são diferenciadas as atividades que incentivam uma 
postura cidadã bastante individual e passiva daquelas que almejam posturas mais coletivas e participativas.

O eixo VI, denominado “Contexto da prática docente”, diz respeito à realidade em que a atuação docente está inserida, isto é, às peculiaridades da escola em que ocorrem as atividades didáticas. Fazem parte deste eixo tanto a influência que o currículo exerce na atividade realizada, quanto sua extensão.

Ainda que em nossas leituras e análises não tenha sido possível encontrar nenhuma relação explícita entre estes aspectos e abordagens voltadas à cidadania distintas, consideramos que eles são essenciais para se compreender as possibilidades da ação docente no seu contexto de atuação. Um contexto em que o currículo vigente limita a liberdade dos professores, assim como a obrigatoriedade de inserções pontuais, é bastante distinto de um contexto sem a obrigatoriedade de seguir um currículo à risca ou obedecer a cronogramas inflexíveis.

O eixo VII, finalmente, se volta para a “Cidadania apresentada pelos autores”. São focos deste eixo as concepções apresentadas pelos autores sobre cidadania, mencionadas, principalmente, ao longo de sua discussão teórica, mas também em outros momentos do texto, como nos objetivos das atividades didáticas.

Vale a pena destacar que não avaliamos, neste eixo, se as concepções de cidadania dos autores de fato se concretizam em suas práticas didáticas, mas sim nos restringimos apenas às palavras e expressões que são mencionadas pelos autores para se referirem à cidadania e qual o seu papel nas atividades desenvolvidas.

O processo de análise que deu origem aos sete eixos e suas categorias, assim como a posterior análise dos 16 trabalhos seguindo os eixos identificados, se deu com a reunião das informações relevantes apresentadas pelos trabalhos, contando, preferencialmente, com excertos

Além dessas informações diretas dos trabalhos, nos usamos, também, de nossas “compreensões”, isto é, comentários sobre as nossas percepções mais gerais, incluindo algumas interpretações e inferências, tendo por base os excertos e demais trechos dos trabalhos. Apresentamos a ficha a seguir como exemplo de análise, sendo as fichas dos outros textos reunidas em anexo. ${ }^{30}$

30 Em todas as fichas de análise optamos por apresentar os excertos dos textos como estavam escritos nos trabalhos, sem acrescentar a expressão "sic" quando haviam erros de português e sem corrigir os erros cometidos pelos autores, pois julgamos que eles não comprometem a interpretação. 
Tabela 9 - Ficha de análise do trabalho Moura e Comaru (2015)

\begin{tabular}{|c|c|c|}
\hline $\begin{array}{l}\text { Eixo de } \\
\text { Análise }\end{array}$ & & Informações extraídas e comentários \\
\hline \multirow{2}{*}{$\begin{array}{c}\text { Tema de } \\
\text { Referência }\end{array}$} & $\begin{array}{l}\text { Apresentado } \\
\text { pelos autores }\end{array}$ & Ecologia \\
\hline & Compreensão & $\begin{array}{c}\text { O tema escolhido para a sequência de aulas foi “Ecologia”, tema atual, amplo e } \\
\text { com potencialidade para o encaminhamento de atividades interdisciplinares e } \\
\text { voltadas à cidadania. }\end{array}$ \\
\hline \multirow{2}{*}{$\begin{array}{l}\text { Relação do } \\
\text { professor com } \\
\text { o } \\
\text { conhecimento } \\
\text { científico }\end{array}$} & $\begin{array}{l}\text { Apresentado } \\
\text { pelos autores }\end{array}$ & $\begin{array}{c}\text { “Na Prática Social Inicial, os alunos foram desafiados a atingir os objetivos de } \\
\text { construção de novos conhecimentos acerca do tema 'Ecologia'.” "Os alunos } \\
\text { compreenderam a importância de criar esse livro”" }\end{array}$ \\
\hline & Compreensão & $\begin{array}{l}\text { Os alunos não tiveram um papel principal na seleção do tema. A temática } \\
\text { ecologia e sua relação com o cuidado do meio ambiente, por sua vez, não se } \\
\text { tratam apenas de um tema cotidiano, mas de um tema cidadão. }\end{array}$ \\
\hline \multirow[t]{2}{*}{$\begin{array}{l}\text { Engajamento } \\
\text { dos alunos }\end{array}$} & $\begin{array}{l}\text { Apresentado } \\
\text { pelos autores }\end{array}$ & $\begin{array}{l}\text { “Na Prática Social Inicial, os alunos foram desafiados a atingir os objetivos de } \\
\text { construção de novos conhecimentos acerca do tema ‘Ecologia'.” } \\
\text { “A proposta da confecção de um ‘Livro de Pano' como arte sequencial foi } \\
\text { aceita pelos alunos.” “Os alunos preencheram as fichas da Prática Social Final } \\
\text { demonstrando interesse e disposição para uma nova postura prática frente aos } \\
\text { desafios ambientais de seu tempo” “As falas dos alunos demostraram que eles } \\
\text { puderam assimilar algo de novo durante a construção dos conceitos em } \\
\text { Ecologia, revelando uma disposição para enfrentamento de situações em defesa } \\
\text { do meio em que vivem e de uma postura mais sustentável” }\end{array}$ \\
\hline & Compreensão & $\begin{array}{l}\text { Tanto pelo fato dos alunos terem sido “desafiados” e a proposta “aceita”, } \\
\text { quanto pela descrição das suas participações, na forma de "demonstrar interesse } \\
\text { e disposição” e “assimilando” algo novo, parece que os alunos foram tocados e } \\
\text { motivados pela atividade, mas não em um nível muito grande. }\end{array}$ \\
\hline \multirow[t]{2}{*}{$\begin{array}{l}\text { Atividades } \\
\text { desenvolvidas } \\
\text { em sala }\end{array}$} & $\begin{array}{l}\text { Apresentado } \\
\text { pelos autores }\end{array}$ & $\begin{array}{l}\text { Três momentos pedagógicos, construção em grupos do livro de pano passos da } \\
\text { Pedagogia Histórico Crítica: a) Prática social inicial do conteúdo; b) } \\
\text { Problematização; c) Instrumentalização; d) Catarse; e) Prática social final do } \\
\text { conteúdo. Problematização do conteúdo: foram destacados o ambiente como } \\
\text { “nossa casa” e o planeta como referencial para a vida coletiva, assim como as } \\
\text { dimensões conceitual/científica, social, econômica/política, histórico/filosófica } \\
\text { e ético/ideológica. Instrumentalização: aulas com datashow incluindo cenas do } \\
\text { cotidiano, ecossistemas, componentes bióticos e abióticos, etc. Catarse por } \\
\text { meio de grupo focal. Prática social final: “Nesse momento cada aluno } \\
\text { manifestou por escrito sua nova atitude e sua proposta de ação para } \\
\text { desenvolvimento de uma postura cidadã”, detalhando o que precisa ser feito e } \\
\text { como deve ser feito, associando com o conteúdo. Essas ações são elencadas do } \\
\text { ponto de vista individual. }\end{array}$ \\
\hline & Compreensão & $\begin{array}{l}\text { Ainda que de fato sejam realizadas muitas atividades em sala, não fica claro } \\
\text { como elas foram articuladas, isto é, como os conteúdos de Biologia ensinados } \\
\text { ajudaram ou não nas outras partes da proposta didática, como foi feita a ligação } \\
\text { entre nosso planeta como “nossa casa” e as ações para ajudar em sua } \\
\text { preservação, mesmo que a atividade final cobrasse essa relação. }\end{array}$ \\
\hline $\begin{array}{l}\text { Participação } \\
\text { na sociedade }\end{array}$ & $\begin{array}{l}\text { Apresentado } \\
\text { pelos autores }\end{array}$ & $\begin{array}{l}\text { “Os alunos compreenderam a importância de criar esse livro como forma de } \\
\text { perpetuar a passagem de cada um deles pela escola, uma vez que o mesmo } \\
\text { passará a fazer parte do acervo da biblioteca da Instituição.” }\end{array}$ \\
\hline
\end{tabular}




\begin{tabular}{|c|c|c|}
\hline $\begin{array}{l}\text { Eixo de } \\
\text { Análise }\end{array}$ & & Informações extraídas e comentários \\
\hline $\begin{array}{l}\text { que os alunos } \\
\text { desenvolvem }\end{array}$ & Compreensão & $\begin{array}{l}\text { A proposta é tida como possuindo relação com a ação na sociedade na forma de } \\
\text { um livro que perpetuará a passagem dos alunos pela escola. Além deste livro de } \\
\text { pano com relação um tanto indireta com a cidadania, temos também a "Prática } \\
\text { Social Final”, em que os alunos são incentivados a mobilizar o que precisa ser } \\
\text { feito e como essas ações serão feitas. Vale a pena destacar, porém, que essas } \\
\text { ações devem ser pensadas em um nível individual. }\end{array}$ \\
\hline \multirow{2}{*}{$\begin{array}{c}\text { Contexto da } \\
\text { prática } \\
\text { docente }\end{array}$} & $\begin{array}{l}\text { Apresentado } \\
\text { pelos autores }\end{array}$ & Ensino Médio em escola pública em 16 aulas. Disciplina de Biologia \\
\hline & Compreensão & Nada a comentar \\
\hline \multirow[t]{2}{*}{$\begin{array}{c}\text { Cidadania } \\
\text { apresentada } \\
\text { pelos autores }\end{array}$} & $\begin{array}{l}\text { Apresentado } \\
\text { pelos autores }\end{array}$ & $\begin{array}{c}\text { Alfabetização Científica com Pedagogia Histórico Crítica } \\
\text { “cidadania, capaz de criar no educando, uma visão holística suficientemente } \\
\text { sólida para um embate responsável e criativo, frente aos desafios de um mundo } \\
\text { globalizado.” } \\
\text { “a leitura de um mundo ao redor acontece antes da leitura pela palavra” (Freire) } \\
\text { a “‘população disponha de conhecimentos científicos e tecnológicos } \\
\text { necessários para se desenvolver na vida diária, ajudar a resolver os problemas e } \\
\text { as necessidades de saúde e sobrevivência básica, tomar consciência das } \\
\text { complexas relações entre ciência e sociedade’” }\end{array}$ \\
\hline & Compreensão & Nada a comentar \\
\hline
\end{tabular}

Fonte: Bondezan (2019).

Cada um dos sete eixos de análise conta com certo número de categorias que busca detalhar suas respectivas informações. Elas foram construídas de maneira a possuírem naturezas compatíveis entre si e buscando seguir uma gradatividade com relação ao modo com que incentivam uma postura cidadã.

Para a construção das categorias, reunimos as informações e os aspectos que apareceram com maior recorrência dentro dos eixos de análise. As ocasiões que exigiram um processo mais elaborado para a construção das categorias serão detalhadas em momento oportuno.

Ainda que exista, em alguma medida, juízos de valor em diversos momentos das fichas de análise, já que é impossível uma total imparcialidade do pesquisador, as categorias foram construídas tendo em mente que as atividades em sala de aula dependem de diversos fatores, como a concepção de cidadania de seus idealizadores e o contexto escolar em que as práticas estão inseridas. Não cabe, assim, nenhum julgamento das práticas aplicadas e não consideramos que existam, a priori, práticas em sala de aula, encaminhamentos didáticos ou visões de cidadania preferíveis ou mais desejáveis que outros.

A tabela 10, a seguir, contém todos os eixos de análise, assim como suas respectivas categorias, a serem detalhadas a seguir. 
Tabela 10 - Eixos e categorias da segunda análise

\begin{tabular}{|c|c|c|}
\hline & Nome do Eixo & Categorias do eixo \\
\hline I & $\begin{array}{c}\text { Tema de } \\
\text { Referência }\end{array}$ & $\begin{array}{l}\text { - Tema de referência muito específico } \\
\text { - Tema de referência com pouca potencialidade para a cidadania } \\
\text { - Tema atual e cotidiano com potencialidade para a cidadania } \\
\text { - Tema abrangente e com grande potencialidade para a cidadania }\end{array}$ \\
\hline II & $\begin{array}{l}\text { Relação do } \\
\text { professor com } \\
\text { o } \\
\text { conhecimento } \\
\text { científico }\end{array}$ & $\begin{array}{l}\text { - Conhecimento advindo do conteúdo curricular } \\
\text { - Conhecimento advindo de um tema cotidiano } \\
\text { - Conhecimento advindo de uma temática cidadã }\end{array}$ \\
\hline III & $\begin{array}{l}\text { Engajamento } \\
\text { dos alunos }\end{array}$ & $\begin{array}{l}\text { - Alunos pouco afetados pelas atividades } \\
\text { - Alunos burocraticamente motivados pela abordagem } \\
\text { - Alunos parcialmente motivados, sem engajamento profundo } \\
\text { - Alunos profundamente motivados }\end{array}$ \\
\hline IV & $\begin{array}{l}\text { Atividades } \\
\text { desenvolvidas } \\
\text { em sala }\end{array}$ & $\begin{array}{c}\text { - Atividades expositivas ou de leitura } \\
\text { - Levantamento das concepções iniciais dos alunos e problematizações iniciais } \\
\text { - Atividades de discussão em grupos, em aulas dialógicas ou debates } \\
\text { - Atividades de elaboração individual } \\
\text { - Atividades de elaboração coletiva }\end{array}$ \\
\hline $\mathrm{V}$ & $\begin{array}{l}\text { Participação na } \\
\text { sociedade que } \\
\text { os alunos } \\
\text { desenvolvem }\end{array}$ & $\begin{array}{l}\text { - Não diretamente relacionada com a vida em sociedade ou extremamente limitada } \\
\text { - Relacionada com a vida em sociedade de maneira individual e limitada } \\
\text { - Relacionada com a vida em sociedade de maneira individual e ativa } \\
\text { - Relacionada com a vida em sociedade de maneira coletiva e ativa }\end{array}$ \\
\hline VI & $\begin{array}{c}\text { Contexto da } \\
\text { prática docente }\end{array}$ & $\begin{array}{c}\text { - Ensino formal, várias aulas } \\
\text { - Ensino formal, em poucas aulas } \\
\text { - Ensino não formal } \\
\text { - Maior rigidez curricular } \\
\text { - Menor rigidez curricular } \\
\text { (não exclusivas) }\end{array}$ \\
\hline VII & $\begin{array}{l}\text { Cidadania } \\
\text { apresentada } \\
\text { pelos autores }\end{array}$ & $\begin{array}{l}\text { - Alfabetização Científica, CTS(A) e QSC como motivadoras, associadas ou não à } \\
\text { cidadania } \\
\text { - Cidadania incentivada na forma do desenvolvimento de “interpretação de mundo” e } \\
\text { "tomada de consciência”, se aproximando das Percepções } \\
\text { - Cidadania como se dedicando à “ética”, a “valores” e promovendo o “pensamento } \\
\text { crítico”, se aproximando dos Questionamentos } \\
\text { - Cidadania como “posicionar-se frente” a algo, se aproximando do Compromisso Social, } \\
\text { mas que ainda não foi transformada em ação concreta em sociedade } \\
\text { - Cidadania na forma de “resolução de problemas”, “tomada de decisão”, } \\
\text { “desenvolvimento de atitudes”, “embate responsável”, “exercer direitos”, se } \\
\text { aproximando do Compromisso Social }\end{array}$ \\
\hline
\end{tabular}

Fonte: Bondezan (2019).

Para o eixo I, “Tema de referência”, foram construídas categorias que fossem capazes de identificar os temas de referência dos trabalhos, mas não em sua dimensão mais específica, como “cinemática escalar” ou "radioatividade”, nem em sua dimensão mais geral, tal como fizemos no aspecto Temática do Trabalho da primeira análise.

Para esse eixo, as categorias foram construídas com o objetivo de diferenciar a potencialidade dos respectivos temas para a cidadania, contando com quatro níveis distintos. 
Esta potencialidade, que seria específica do tema e o mais distante possível de encaminhamentos metodológicos, é dada por sua localidade ou abrangência, assim como sua relação com a cidadania.

Um tema de referência como “calor latente”, por exemplo, seria profundamente curricular e específico, bastante distante de qualquer relação mais ampla com a sociedade. Por outro lado, um tema como “água” seria bastante amplo, não se limitando a nenhum ramo da ciência e estando profundamente ligado à cidadania.

Cada trabalho foi classificado dentro de apenas uma das quatro categorias, conforme a localidade dos respectivos temas de referência e seu potencial para a cidadania.

Para o eixo II, "Relação do professor com o conhecimento científico”, foram construídas categorias que fossem capazes de diferenciar qual a principal motivação para o estudo de determinado conhecimento científico na prática realizada em sala.

As categorias deste eixo diferenciam os conhecimentos como advindos de um conteúdo curricular, de um tema cotidiano ou de uma temática cidadã, fatores que julgamos ser os principais influenciadores de atividades em sala de aula com foco na cidadania.

Os trabalhos foram classificados em apenas uma das três categorias, buscando-se identificar o fator mais importante para a motivação da abordagem.

No eixo III, "Engajamento dos alunos”, as categorias foram construídas de maneira a quantificar o engajamento dos alunos nas atividades realizadas, diferenciando os alunos pouco afetados e distantes daqueles que apresentaram maior grau de engajamento.

A classificação foi feita sempre com base nos relatos apresentados pelos autores, tendo como base os depoimentos dos alunos, professores ou pesquisadores sobre a participação dos estudantes nas atividades. Mensurar o engajamento dos alunos, contudo, apresenta algumas subjetividades, pois pode ser flutuante no decorrer das aulas, assim como ser superestimado ou subestimado por professores e pesquisadores.

Quando comportamentos muito distintos de alunos ou grupos de alunos foram relatados em uma mesma atividade, optamos por identificar as duas categorias correspondentes às suas percepções.

Nem sempre foi possível identificar com precisão qual o engajamento dos alunos. Para esses casos, optamos ou por não realizar a classificação, quando não possuíamos elementos, ou por classificá-lo em mais de uma categoria, quando tínhamos apenas informações sobre o engajamento mínimo ou máximo dos estudantes. 
O eixo IV, sobre as “Atividades desenvolvidas em sala”, teve categorias construídas de maneira a levar em consideração os diversos tipos de postura que os estudantes podem ter nas aulas, desde posturas mais passivas em aulas expositivas, até posturas mais ativas em atividades coletivas e colaborativas.

Foram consideradas maneira distinta, com categoria específica, as atividades que levantavam as concepções iniciais dos alunos e aquelas que realizavam problematizações iniciais. Agimos desta maneira porque estas atividades podem ocorrer de diversas maneiras, nem sempre havendo detalhes suficientes nos trabalhos sobre a forma como são executadas.

Um levantamento de concepções iniciais pode ocorrer tanto com o uso de um questionário individual, quanto por meio de entrevista individual ou ainda por meio de grupo focal, com a participação de outros alunos. As problematizações iniciais, por sua vez, podem ocorrer de maneiras distintas, existindo, inclusive, a associação que alguns autores fazem entre o levantamento de concepções iniciais e as problematizações iniciais.

Fizemos a distinção, também, entre as atividades de elaboração individual e as de elaboração coletiva, pois, mesmo que ambas incentivem a criatividade dos alunos e seu protagonismo, acreditamos que estas têm maior potencial para a troca de ideias entre eles e os incentivem a colaborar entre si, almejando uma mesma finalidade.

Em atividades extensas, os alunos participam de atividades em que desempenham posturas distintas, havendo, portanto, uma afinidade de um mesmo trabalho para mais de uma categoria.

Para o eixo V, "Participação na sociedade que os alunos desenvolvem”, as categorias construídas num primeiro momento se mostraram insuficientes para nosso objetivo. Originárias diretamente dos elementos que apareceram nos trabalhos, as categorias acabaram possuindo um número elevado, frequentemente ligadas a aspectos específicos das propostas didáticas analisadas e nem sempre tendo uma mesma natureza.

A tabela 11, a seguir, apresenta as categorias criadas num primeiro momento, a partir da análise dos trabalhos do X ENPEC, bem como aquelas que foram obtidas após um processo de sistematização, a ser detalhado a seguir. 
Tabela 11- Categorias iniciais e finais do eixo $\mathrm{V}$

\begin{tabular}{|c|c|}
\hline Categorias iniciais, com aspectos específicos dos trabalhos & Categorias finais, com os aspectos sistematizados \\
\hline $\begin{array}{c}\text { - Livro de pano como forma de perpetuar a passagem dos } \\
\text { alunos pela escola } \\
\text { - Prática Social Final em nível individual } \\
\text { - Desenvolvimento de habilidades laboratoriais } \\
\text { - Elaboração de Painéis comparativos } \\
\text { - Uso de celulares e tecnologias } \\
\text { - Construção de cartilhas sobre o lixo caseiro } \\
\text { - Projeto de ação a partir da situação-problema, em } \\
\text { caráter coletivo } \\
\text { - Produção de vídeo sobre a degradação de energia e a } \\
\text { mobilidade urbana } \\
\text { - Elaboração e apresentação de música/paródia ou } \\
\text { teatro }\end{array}$ & $\begin{array}{c}\text { - Não diretamente relacionadas com a vida em } \\
\text { sociedade ou extremamente limitada } \\
\text { - Relacionada com a vida em sociedade de } \\
\text { maneira individual e limitada } \\
\text { - Relacionada com a vida em sociedade de } \\
\text { maneira individual e ativa } \\
\text { - Relacionada com a vida em sociedade de } \\
\text { maneira coletiva e ativa }\end{array}$ \\
\hline
\end{tabular}

Fonte: Bondezan (2019).

Os aspectos que diziam respeito à construção de um livro de pano para perpetuar a passagem dos alunos pela escola, ao desenvolvimento das habilidades das alunas em laboratório e ao uso de celulares em sala de aula como ferramentas tecnológicas, por exemplo, apesar de suas diferenças, apresentam afinidades.

Quando considerados segundo a relação que possuem com a cidadania incentivada, em todos eles há uma relação indireta com a cidadania, ou uma relação bastante frágil, o que os levou a serem reunidos dentro da categoria "Não diretamente relacionadas com a vida em sociedade ou extremamente limitada”.

Um processo similar foi feito para cada uma das outras categorias. Na segunda delas foram reunidas as participações dos alunos em sociedade que ocorriam de maneira individual e limitada, isto é, quando os alunos são incentivados a agir individualmente e de maneira distante a um ativismo propositivo, como quando fazem a coleta seletiva e quando evitam o uso de determinadas embalagens ou produtos.

A terceira categoria inclui as participações dos alunos em sociedade que ocorrem de maneira individual e ativa, isto é, quando eles são incentivados a desempenhar ativismos individuais, como a preservação do meio ambiente através do descarte adequado de materiais e a limpeza de áreas degradadas.

Finalmente, na quarta categoria, são reunidas as participações que buscam um ativismo coletivo, quando os alunos são incentivados a agir de maneira coletiva ou associada a movimentos sociais e desempenhando atividades propositivas.

Vale a pena destacar que cada trabalho foi classificado em apenas uma categoria e, quando as atividades desempenhadas pelos alunos possuíam relações diferentes com a prática 
em sociedade, decidimos por destacar aquela que mais predominou ou aquela que se mostrou mais ativa.

No eixo VI, “Contexto da prática docente”, as categorias foram construídas de maneira a detalhar o contexto em que se inserem as atividades relatadas nos trabalhos. Dentre os muitos fatores que influenciam o ambiente escolar e a atuação docente, destacamos a extensão das atividades relatadas e a influência exercida pelo currículo escolar e demais entidades reguladoras.

Diferenciamos, assim, as atividades de caráter mais pontual, desenvolvidas no ensino formal em menos de 5 aulas, daquelas mais extensas, desenvolvidas em várias semanas ou até mesmo em um bimestre inteiro. Foram diferenciadas, também, as atividades que não se inseriram no contexto formal, mas sim no contra turno do ensino regular ou em projetos de extensão, com duração mais flexível.

Foram diferenciados, ainda, os trabalhos que sofreram mais influência da rigidez curricular dos que sofreram menos. Esta distinção é importante pois a pressão do currículo, assim como dos inúmeros fatores que influenciam a atividade docente, como avaliações externas e equipe supervisora, pode limitar a ação e a liberdade dos professores em suas aulas. Classificamos os trabalhos como sofrendo influência limitadora do currículo apenas quando esta foi explicitamente mencionada no corpo do texto.

As categorias deste eixo são, portanto, não exclusivas, caracterizando a extensão e a influência sofrida pelos trabalhos.

Para o eixo VII, finalmente, intitulado “Cidadania apresentada pelos autores”, as categorias construídas tiveram como ponto de partida os Propósitos Educacionais de Strieder (2012), isto é, a cidadania como buscando desenvolver Percepções, Questionamentos ou Compromisso Social. Além dessas categorias, porém, foram incluídas outras duas:

A primeira delas buscava incluir os trabalhos que faziam menção à Alfabetização Científica, à ênfase CTS(A) ou às Questões apenas como motivadoras das atividades desenvolvidas, sem nenhuma relação mais profunda com a cidadania ou com os pressupostos teóricos destas ênfases.

A segunda categoria incluída tinha similaridades com o desenvolvimento de um Compromisso Social, mas, diferentemente deste, incluía trabalhos que permaneceram apenas na pretensão de colocar em prática este Propósito Educacional, não incentivando os alunos a de fato modificar a realidade em que estão inseridos. 
Para identificar a aproximação dos trabalhos analisados com cada uma destas categorias, optamos por destacar algumas expressões utilizadas pelos autores para se referir a concepção de cidadania que possuem e associá-las com as categorias deste eixo. Expressões como “interpretação de mundo”, “tomada de consciência”, por exemplo, se aproximariam do desenvolvimento de Percepções, enquanto expressões como “ética”, “valores” e "pensamento crítico”, se aproximam dos Questionamentos.

Em alguns trechos dos textos analisados, contudo, os autores descrevem atividades realizadas e concepções de cidadania diferentes das identificadas nas categorias deste eixo. Estas passagens, destacadas de maneira diferenciada, dizem respeito a "liberdade de questionar" dos alunos, ao "abandono de uma postura passiva por uma postura crítica”, ao “exercício da cidadania”, etc.

Estas passagens, embora dialoguem em alguma medida com a cidadania, acabam sendo um tanto vagas, sem definir com maior precisão o que ela seria e qual o posicionamento dos alunos com relação a ela. Aparecem, também, passagens que se usam de conceitos que podem estar associados apenas ao fazer experimental e a atividades em grupo, se distanciando da cidadania propriamente dita. Fazem parte deste grupo, também, expressões como “socioeconômicas”, “sócio-históricas”, “sociopolíticas” e "socioculturais”, usadas sem um maior detalhamento.

Todos os textos fizeram menção a várias das expressões aqui mencionadas, indicando uma afinidade, em diferentes medidas, com várias das categorias deste eixo.

Vale a pena reforçar que não existem juízos de valor em nenhuma das categorias dos sete eixos aqui descritos, isto é, nenhuma das categorias inclui concepções de cidadania ou atividades em sala de aula que sejam, a priori, mais desejáveis que outras, já que dizem respeito a contextos específicos de aplicação, com respectivas especificidades.

Os eixos e as categorias aqui apresentados e descritos são fruto da análise dos trabalhos selecionados, refletindo seus conteúdos e características. Nenhuma das pesquisas analisadas fez referência a livros didáticos ou a atividades investigativas, o que justifica sua ausência nos eixos e categorias construídos.

Os resultados da análise dos trabalhos seguindo os sete eixos e as suas respectivas categorias aqui descritas serão apresentados na seção seguinte, com as suas implicações para diferentes abordagens voltadas à cidadania sendo discutidas no capítulo 7. 


\subsection{Diferentes formas de colocar em prática os aspectos influenciadores}

Serão apresentados, nesta seção, os resultados da análise realizada, cujos detalhes sobre a seleção de amostra, construção dos eixos e categorias foram descritos anteriormente. Estes resultados serão apresentados segundo cada um dos eixos, separados em subseções distintas.

De todos os trabalhos publicados no X e no XI ENPEC (2015 e 2017), selecionamos, para a segunda análise, apenas aqueles que se voltavam às ênfases relacionadas à promoção da cidadania e descreviam com detalhes as atividades realizadas no Ensino Médio e no Ensino Superior em Licenciaturas, num total de 16.

A análise ocorreu segundo sete eixos, a saber, "Tema de Referência”, "Relação do professor com o conhecimento científico”, “Engajamento dos alunos”, “Atividades desenvolvidas em sala”, "Participação na sociedade que os alunos desenvolvem”, “Contexto da prática docente” e “Cidadania apresentada pelos autores”, cada um com categorias específicas.

Os resultados das análises são mostrados na forma de fichas, contendo a reunião das informações relevantes, preferencialmente com excertos, e comentários sobre nossas percepções e interpretações mais gerais, influenciadas por informações dos textos não mencionadas nos excertos.

Estão presentes nas fichas, também, a afinidade de cada um dos trabalhos com cada uma das categorias, a ser discutida e interpretada no capítulo seguinte.

\subsubsection{Tema de Referência}

O eixo I, denominado “Tema de Referência”, busca identificar a potencialidade do tema científico escolhido para a cidadania, tendo como base a sua localidade ou abrangência. Suas quatro categorias diferenciam um tema de referência muito específico e localizado, um tema específico mas com alguma potencialidade para a cidadania, um tema atual e cotidiano, e, finalmente, um tema bastante abrangente e com grande potencialidade para a cidadania.

A tabela 12, a seguir, contém a ficha de análise para o primeiro eixo. 
Tabela 12 - Ficha de análise do eixo I, "Tema de Referência”

\begin{tabular}{cc}
\hline Trab. & Informações extraídas e comentários \\
\hline (1) & $\begin{array}{c}\text { Ecologia } \\
\text { Compreensões: O tema escolhido para a sequência de aulas foi “Ecologia”, tema atual, amplo e com } \\
\text { potencialidade para o encaminhamento de atividades interdisciplinares e voltadas à cidadania. }\end{array}$ \\
\hline & Biodiesel \\
(2) & $\begin{array}{c}\text { Compreensões: O tema biodiesel é bastante atual e cotidiano, sendo frequentemente retratado em } \\
\text { noticiários. Contudo, ele não é tão amplo como “combustíveis”, o que o deixa um pouco mais distante } \\
\text { de abordagens mais gerais e interdisciplinares. }\end{array}$ \\
\hline
\end{tabular}

Combustíveis fósseis e alternativos

(3) Compreensões: O tema abordado é bastante abrangente e tem grande potencialidade para a cidadania e para abordagens envolvendo a interdisciplinaridade

\section{Cinemática Escalar}

(4) Compreensões: O tema "movimentos" seria um tema que, embora bastante distante da cidadania em si,

é bastante amplo e torna abordagens mais abrangentes algo possível. O tema “cinemática escalar”, contudo, além de pouca potencialidade para a cidadania, é muito restrito e localizado.

\section{Lixo}

(5) Compreensões: O tema "lixo” é bastante abrangente e possui grande potencialidade para práticas voltadas à cidadania.

\section{Termodinâmica}

(6) Compreensões: O tema de referência é bastante científico, bastante localizado e com relação não tão direta com o cotidiano ou com a cidadania. Isso não impede, porém, que os autores não consigam fazer este tema dialogar com o cotidiano e a cidadania.

\section{Radioatividade}

(7) Compreensões: O tema Radioatividade, apesar de bastante curricular, é amplo e está frequentemente presente no cotidiano na forma de noticiários e até mesmo na escolha da matriz energética de um país, se aproximando da cidadania.

\section{Lentes esféricas}

(8) Compreensões: O tema escolhido pelos autores é bastante localizado e curricular, ficando um tanto distante de abordagens mais amplas e voltadas à cidadania.

\section{Efeito fotoelétrico}

(9) Compreensões: Este tema é extremamente pontual e restrito, o que o torna bastante distante de uma abordagem mais ampla, visando a cidadania, por exemplo.

“produção artesanal de vinagre a partir de caldo de cana” Compreensões: O tema de referência é bastante localizado e curricular, dificultando qualquer abordagem mais geral e cidadã.

"remediação ambiental de áreas contaminadas"

Compreensões: A temática é bastante ligada ao meio ambiente, sua conservação e diminuição de danos causados por humanos. Além disso, ela é bastante ampla e passível de ser trabalhada do ponto de vista da cidadania.

\section{Produção de açúcar}

(12) Compreensões: A produção de açúcar é um tema não curricular, mas extremamente localizado e com abordagens mais gerais, apesar de possíveis, como retrata o presente trabalho, bastante difíceis.

"Matriz Energética Brasileira”

Compreensões: O tema “matriz energética” é bastante amplo, não estando restrito a nenhuma disciplina curricular ou conhecimento científico pré estabelecido, possuindo bastante potencialidade para abordagens cidadãs. 


\begin{tabular}{|c|c|}
\hline Trab. & Informações extraídas e comentários \\
\hline$(14)$ & $\begin{array}{l}\text { Consumo de alimentos industrializados } \\
\text { Compreensões: O tema alimentos industrializados talvez até esteja em alguma medida presente no } \\
\text { cotidiano, mas não com grande frequência, e sua relação com a cidadania não é tão evidente. }\end{array}$ \\
\hline$(15)$ & $\begin{array}{c}\text { “influência da concentração de soluções de íons metálicos } \mathrm{Cu}, \mathrm{Zn}, \mathrm{Al} \text { e Fe, no crescimento de raízes de } \\
\text { batata doce” } \\
\text { Compreensões: O tema escolhido pelos autores é bastante específico e, embora não exatamente } \\
\text { curricular da disciplina de Química, é bastante difícil de se relacionar de maneira geral com as outras } \\
\text { disciplinas ou com a cidadania. }\end{array}$ \\
\hline (16) & $\begin{array}{c}\text { Produção de alimentos } \\
\text { Compreensões: O tema “produção de alimentos” é bastante amplo, não estando restrito a um conceito } \\
\text { de uma disciplina e nem mesmo a uma disciplina. Sua potencialidade para a cidadania é um tanto } \\
\text { indireta, com grande capacidade de ser localizada e limitada. }\end{array}$ \\
\hline & $\begin{array}{c}\text { - Tema de referência muito específico }(4,8,9,10,15) \\
\text { - Tema de referência com pouca potencialidade para a cidadania }(6,12,14) \\
\text { - Tema atual e cotidiano com potencialidade para a cidadania }(2,16) \\
\text { - Tema abrangente e com grande potencialidade para a cidadania }(1,3,5,7,11,13)\end{array}$ \\
\hline
\end{tabular}

Fonte: Bondezan (2019).

\subsubsection{Relação do professor com o conhecimento científico}

O eixo II, “Relação do professor com o conhecimento científico”, por sua vez, busca detalhar a origem do conhecimento científico, assim como os agentes do ambiente educacional que participam da sua escolha. São três as categorias deste eixo: conhecimento advindo de um conteúdo curricular, de um tema cotidiano e de uma temática cidadã.

A tabela 13, a seguir, contém a ficha de análise para o segundo eixo.

Tabela 13 - Ficha de análise do eixo II, “Relação do professor com o conhecimento científico"

\begin{tabular}{|c|c|}
\hline Trab. & Informações extraídas e comentários \\
\hline (1) & $\begin{array}{l}\text { “Na Prática Social Inicial, os alunos foram desafiados a atingir os objetivos de construção de novos } \\
\text { conhecimentos acerca do tema ‘Ecologia’.” "Os alunos compreenderam a importância de criar esse } \\
\text { livro” } \\
\text { Compreensões: Os alunos não tiveram um papel principal na seleção do tema. A temática ecologia e } \\
\text { sua relação com o cuidado do meio ambiente, por sua vez, não se tratam apenas de um tema cotidiano, } \\
\text { mas de um tema cidadão. }\end{array}$ \\
\hline (2) & $\begin{array}{c}\text { “incentivá-las a ingressar em carreiras de Ciências Exatas e Tecnológicas” } \\
\text { Compreensões: Embora a síntese do biodiesel seja um tema que aparece frequentemente na mídia, } \\
\text { sendo, portanto, cotidiano, ele acaba sendo tratado como um pretexto para as atividades de laboratório, } \\
\text { isto é, como sendo curricular. }\end{array}$ \\
\hline
\end{tabular}


Trab.

Informações extraídas e comentários

“No ensino de Química, por exemplo, a contextualização dos conteúdos químicos pode ser feita com a inserção de questões sociocientíficas (QSC), entendidas como questões ambientais, políticas, econômicas, éticas, sociais e culturais relativas à ciência e à tecnologia”, que buscam “‘encorajar os alunos a relacionar suas experiências escolares em ciências com problemas de seu cotidiano e desenvolver responsabilidades social'” “a temática Combustíveis fósseis e alternativos parece ser bem promissora para inserção em sala de aula de questões sociocientíficas”

Compreensões: Segundo a fundamentação teórica do trabalho, a cidadania é central para a abordagem, com os conteúdos científicos sendo necessários para a discussão dos combustíveis fósseis. Do ponto de vista prático não fica claro se a cidadania é mais importante que o cotidiano, inclusive porque a atividade relatada não é a primeira a ser realizada.

"No enfoque CTS podemos ensinar uma ciência mais aproximada da realidade do estudante buscando para isso elementos que fazem parte do cotidiano dos mesmos e dentro desta visão que este trabalho foi desenvolvido" "Na primeira etapa, de apresentação do conteúdo, foram utilizadas três aulas de cinquenta minutos, onde os conceitos de velocidade escalar média e aceleração escalar média foram apresentados pelo professor, em aula expositiva, com o auxilio da plataforma PHET”

Compreensões: Com os autores compreendendo que o enfoque CTS está associado com o uso de tecnologias em sala de aula, assim como experiências e um diálogo íntimo com o cotidiano dos alunos, está bastante claro que o conhecimento científico é tratado do ponto de vista do cotidiano.

“O projeto começou com uma palestra na escola sobre a temática de resíduos sólidos com um representante da Secretaria do Meio Ambiente da cidade de Bagé-RS. Nesta palestra o Representante discutiu sobre o conceito sobre resíduos sólidos, os impactos no ambiente, o trabalho da prefeitura com relação ao lixo, assim como outros aspectos no qual procuraram sensibilizar os alunos ao consumo consciente dos materiais. Todas as abordagens foram discutidas a partir do contexto real da cidade.” Compreensões: A problemática do lixo é tratada como relacionada ao meio ambiente e a sociedade, a ser solucionada pelo governo e pela população geral.

“(a sequência) Foi iniciada com uma problematização inicial, baseada em Auler (2005), que pretendia avaliar os conhecimentos prévios dos alunos sobre o funcionamento do motor de combustão e dos processos de conversão de energia envolvidos em seu funcionamento, além de criar um contexto para estudo da Termodinâmica.

A sequência foi elaborada tendo como objeto o motor de combustão interna. O início da sequência focalizando um objeto da tecnologia tem dois objetivos. Um deles é o de criar um contexto de significação dos conceitos, modelos, leis e teorias que seriam estudados no desenvolvimento da sequência. O outro é o de possibilitar a introdução de uma discussão sobre implicações sociais de determinada tecnologia, após terem sido discutidos seus fundamentos científicos.”

Compreensões: A proposta caminha em direção à cidadania e à promoção de uma "cultura de participação”, mas tem como ponto de partida o motor a combustão, equipamento que estaria presente no cotidiano dos alunos. Além disso, seria o motor o equipamento capaz de contextualizar o estudo dos conhecimentos científicos e possibilitar as discussões sobre as "implicações sociais de determinada tecnologia”.

“a proposta pedagógica sobre Radioatividade foi organizada de forma a contemplar: 1 . O desenvolvimento do conteúdo sobre Radioatividade no formato de aulas expositivas e vídeos. Dentre os assuntos acerca do conteúdo abordados em sala estão a descoberta/histórico da radioatividade; os efeitos das emissões radioativas; a natureza das radiações e suas leis; cinética das desintegrações radioativas; reações artificiais de transmutação; fissão e fusão nuclear; aplicações das reações nucleares e acidentes nucleares.”

(7) "no caso aqui apresentado, as aulas estiveram centradas na abordagem do conhecimento científico, da forma como está presente no livro didático adotado pela escola, sem questionamentos associados ao desenvolvimento científico-tecnológico e suas implicações/relações com a sociedade. Certamente, essa abordagem influenciou as produções dos alunos, em especial os textos elaborados ao final das atividades, que estiveram centrados no conhecimento científico.”

Compreensões: Embora a atividade tenha contemplado dimensões muito mais amplas, seu ponto de partida e fio condutor foi o currículo tradicional, fortemente estabelecido na escola. 
Trab. $\quad$ Informações extraídas e comentários

“A escolha da turma de segundo ano do ensino médio como público alvo justifica-se pelo assunto de Óptica fazer parte do conteúdo programático desta série.”

(8) Compreensões: Tanto pelo tema de referência ser lentes esféricas, portanto, bastante localizado, quanto pelo fato da turma ter sido escolhida por estar estudando ótica, conteúdo programático da série, é possível afirmar que a influência do currículo é bastante grande.

"Para situar o aluno nesse mundo científico, faz-se necessário introduzir no currículo alguns conceitos da Física Moderna, a qual aborda conteúdos fundamentais para a explicação do funcionamento da tecnologia e a produção de uma nova ciência." “propomos a utilização de experimentos em uma aula dialogada expositiva que, consiste na exposição de conteúdo com uma participação ativa dos alunos e levando em consideração a bagagem de conhecimento que eles trazem.”

Compreensões: A proposta tem como fio condutor o conhecimento científico na forma do efeito fotoelétrico. $\mathrm{O}$ aparato experimental aparecerá apenas na terceira aula realizada e com relação um tanto distante com o cotidiano direto dos alunos.

"O objetivo deste trabalho foi o de estudar a construção social da ciência e tecnologia olhando para a produção artesanal de vinagre a partir de caldo de cana, a fim de promover uma educação química interdisciplinar e transdisciplinar.” O objetivo da atividade é: "promover atividades investigativas sobre a produção de vinagre, favorecendo o processo de ensino-aprendizagem de química e contribuindo para apropriação de conhecimentos interdisciplinar/transdisciplinar das ciências da natureza.”

Compreensões: A produção de vinagre certamente é mais central para a atividade do que os conhecimentos químicos. Esta produção parece ser algo ou muito próximo do cotidiano dos alunos, que presenciam a produção caseira deste líquido, ou próxima culturalmente da comunidade. A relação com a cidadania propriamente dita parece estar em segundo plano.

“a questão que norteia essa pesquisa é: ‘Quais as potencialidades da abordagem CTSA com o tema problematizador 'remediação ambiental de áreas contaminadas’ no processo ensino-aprendizagem de estudantes de Ensino Médio?’”

(11)

Compreensões: O conhecimento científico aparece certamente do ponto de vista ambiental, mas acaba por se aproximar mais do cotidiano do que da cidadania, que aparece de maneira mais intensa apenas no debate.

“O objetivo deste trabalho foi o de estudar os aspectos metodológicos de ensino e a educação CTS/CTSA promovida a partir da realização de uma sequência de ensino investigativo de química para debater a temática de produção de açúcar.” “A temática de produção artesanal de açúcar mascavo foi

(12) inspirada na tradição das lanchonetes da cidade de Ibiraçu-ES, que oferecem o pastel e o caldo de cana como produto principal."

Compreensões: A motivação das atividades realizadas é a existência das lanchonetes, portanto, cotidiana.

“O presente artigo traz uma pesquisa por investigação do conceito Energia por meio da utilização do documentário 'Power’” “A abordagem CTS (...) busca contextualizar o Ensino de Ciência por meio de discussões de questões que emergem do cotidiano do estudante, fazendo relações coerentes entre a ciência, a tecnologia e a sociedade.”

Compreensões: O trabalho parece partir do conceito cotidiano de energia e do documentário, que também estaria bastante próximo ao cotidiano. A cidadania e os conteúdos curriculares aparecem em segundo plano.

"Para a escolha da temática a ser trabalhada foram aplicados questionários de reconhecimento da realidade e do contexto vivenciado pelos alunos, o que culminou na escolha dos alimentos

industrializados.” Foi central para a abordagem, também, a “experimentação problematizadora”

Compreensões: Tanto pelo fato dos alunos terem sido consultados para a delimitação do tema estudado, quanto pelo fato da “experimentação problematizadora” estar bastante relacionada com uma situação cotidiana, há grande importância do cotidiano. 


\begin{tabular}{|c|c|}
\hline ab. & rios \\
\hline (15) & $\begin{array}{l}\text { “foram levantados alguns questionamentos sobre as potencialidades pedagógicas (...) de que maneira } \\
\text { uma prática pedagógica de química poderia promover a articulação entre os saberes escolares, } \\
\text { científicos e populares?” "buscou-se introduzir brevemente a origem dos metais, usando o exemplo da } \\
\text { produção de ferro, tendo em vista a situação das empresas localizadas na região metropolitana da } \\
\text { cidade de Vitória, Espírito Santo. (...) Neste caso, foi possível estabelecer conexões entre um dos } \\
\text { conteúdos programáticos de química e a realidade local.” } \\
\text { Compreensões: A produção de batata doce faz parte do contexto do Espirito Santo, assim como o } \\
\text { consumo deste alimento, principalmente por praticantes de atividades físicas. Além disso, este estado } \\
\text { tem papel central na extração, transporte e exportação de minério de ferro. Essas foram as motivações } \\
\text { para o estudo do crescimento da batata doce, e a influência de metais neste crescimento. }\end{array}$ \\
\hline (16) & $\begin{array}{l}\text { “O projeto escolar chamado de ‘EducAlimentar’ (...) cujo objetivo maior foi produzir debates sobre } \\
\text { educação ambientar.” “o projeto escolar se iniciou com a etapa de seleção dos estudantes, e buscando } \\
\text { desafiar, motivar, questionar, sensibilizar, mobilizar, levando-os a produzir conexões entre conteúdos } \\
\text { disciplinares e inter/transdisciplinares, manifestando as suas lutas, realizações e contradições.” A } \\
\text { seleção dos alunos ocorreu por meio de uma prova com tema “educação alimentar”. } \\
\text { Compreensões: O conhecimento científico parece ter como ponto de partida e fio condutor a educação } \\
\text { alimentar, algo que está muito mais próximo do cotidiano dos estudantes do que do currículo ou da } \\
\text { cidadania. }\end{array}$ \\
\hline & $\begin{array}{l}\text { - Conhecimento advindo do conteú } \\
\text { - Conhecimento advindo de um tema cotidian } \\
\text { - Conhecimento advindo de uma te }\end{array}$ \\
\hline
\end{tabular}

Fonte: Bondezan (2019).

\subsubsection{Engajamento dos alunos}

O eixo III, intitulado “Engajamento dos alunos", tem como objetivo identificar o engajamento dos alunos nas atividades desenvolvidas, contando com quatro categorias: alunos pouco afetados pelas atividades, alunos burocraticamente motivados, alunos parcialmente motivados e alunos completamente motivados.

Para a análise, levamos em conta os relatos apresentados pelos autores, mesmo que estes possam ser tendenciosos. Optamos por não realizar a classificação quando não tínhamos elementos suficientes para isso e, quando não foi possível inferir exatamente qual o grau de engajamentos dos alunos, realizamos a classificação considerando a motivação mínima ou máxima.

A ficha de análise para o eixo II está na tabela 14, a seguir. 
Tabela 14 - Ficha de análise do eixo III, "Engajamento dos alunos”

Trab. Informações extraídas e comentários

"Na Prática Social Inicial, os alunos foram desafiados a atingir os objetivos de construção de novos conhecimentos acerca do tema 'Ecologia'."

“A proposta da confecção de um 'Livro de Pano' como arte sequencial foi aceita pelos alunos.” "Os alunos preencheram as fichas da Prática Social Final demonstrando interesse e disposição para uma nova postura prática frente aos desafios ambientais de seu tempo" "As falas dos alunos demostraram que eles puderam assimilar algo de novo durante a construção dos conceitos em Ecologia, revelando uma disposição para enfrentamento de situações em defesa do meio em que vivem e de uma postura mais sustentável"

Compreensões: Tanto pelo fato dos alunos terem sido "desafiados" e a proposta "aceita", quanto pela descrição das suas participações, na forma de "demonstrar interesse e disposição" e "assimilando" algo novo, parece que os alunos foram tocados e motivados pela atividade, mas não em um nível muito grande.

“‘me ajudou na aprendizagem na matéria de Química no colégio em relação aos meus colegas, pois durante as aulas era mais fácil de compreender o conteúdo, em algumas das aulas práticas já conhecíamos alguns dos métodos e os porquês daquela tal reação ou os nomes dos reagentes que utilizávamos'” “"essas alunas aprenderam muito mais do que teoria química, mas aspectos que são relevantes para toda uma vida, como compromisso, companheirismo e gosto pela ciência."

Compreensões: Mesmo que o tema da síntese do biodiesel seja por si só bastante motivador, assim como as ações em laboratórios, no decorrer da proposta são destacados trechos das alunas que apontam para uma motivação restrita ao fazer experimental, bastante burocrática.

"Um aspecto observado foi o fato das questões científicas terem sido pouco ressaltadas pelos alunos." "não identificamos nos painéis comparativos relações desses aspectos com os conceitos químicos neles envolvidos. Contudo, era esperado que os alunos estabelecessem relações entre conceitos químicos e a temática dos combustíveis fósseis e alternativos, dado que o professor já havia ministrado o conteúdo de termoquímica abordando conceitos químicos de energia de ativação, entalpia de reações etc., com os mesmos."

Compreensões: Não há nenhum trecho do trabalho que especifique as reações que os alunos tiveram ao longo da proposta. Foram mencionados, apenas, os conteúdos levantados por eles ao longo do debate.

Contudo, devido ao fato dos alunos não estabelecerem conexões entre os conteúdos químicos anteriormente estudados e a temática dos combustíveis fósseis, talvez eles não estivessem tão engajados com a atividade, mas sim motivados burocraticamente.

“ao serem questionados com relação aos gráficos gerados pelo programa não sabiam relacionar aos conceitos estudados e pesquisados ao longo do trabalho.” "Um dos grupos mencionados além do vídeo experimento confeccionaram um dispositivo com materiais alternativos que representaram como forma

para o cálculo da velocidade escalar média apresentando uma associação com a Robótica livre que realmente surpreendeu a todos os avaliadores inclusive os próprios colegas de sala." "Outro aspecto

demonstrado por alguns estudante foi uma total confusão sobre como e quando a realizações da atividade proposta, ressaltando que estes estudantes não apresentaram o envolvimento necessário para a realização da atividade"

Compreensões: Foi possível perceber um nível de engajamento dos alunos bastante diverso, isto é, tivemos tanto alunos pouco afetados pela abordagem, que mostraram não entender muito bem o que era pedido, quanto alunos que surpreenderam tanto os colegas quanto os pesquisadores indo muito além do que foi pedido e do que era esperado.

\footnotetext{
“A partir disso, foi possível estabelecer que através dos questionários pré e pós-visita ao aterro foi possível considerar que houve uma certa mudança de percepção dos alunos quanto a visão do 'outro' em sociedade."

Compreensões: Embora em nenhum momento são explicitados aspectos sobre a motivação dos estudantes em relação a abordagem, há dados sobre a percepção que eles possuíam a respeito do aterro sanitário antes e depois da visita. Esses dados mostram que houve algum nível de mudança de concepção e de sensibilização dos alunos, que destacaram as "más condições de trabalho dos funcionários" no aterro e a "naturalidade dos funcionários em meio ao lixo".
} 


\begin{tabular}{c} 
Trab. $\quad$ Informações extraídas e comentários \\
\hline “Usar a discussão sobre a estrutura e funcionamento do motor de combustão interna como contexto \\
inicial para o estudo da termodinâmica me motivou para esse estudo.” \\
“Após a problematização inicial, o desenvolvimento da sequência, tendo o livro didático como o \\
principal recurso cria uma descontinuidade, que não explora todas as possibilidades da tecnologia do \\
motor de combustão, em termos do desenvolvimento conceitual. A nosso ver, tal fato refletiu \\
negativamente na motivação dos estudantes e nas relações que efetivamente foram capazes de \\
estabelecer entre a tecnologia, seus usos e os conceitos da termodinâmica.” \\
“Os resultados sustentam a decisão pela continuidade da experiência, porém com um investimento \\
maior na produção de um material alternativo ao livro didático que dê suporte aos desdobramentos \\
apontados na atividade de problematização.” \\
Compreensões: O primeiro excerto é uma das perguntas realizadas pelos autores aos alunos para \\
avaliar a proposta aplicada. Ela, assim como todas as outras, teve resultados positivos que apontam \\
para o potencial da abordagem. Além disso, os autores afirmam que o engajamento dos alunos \\
diminuiu num segundo momento, quando o estudo se deu com base no livro didático. A real motivação \\
dos alunos ao longo da atividade não é detalhada.
\end{tabular}

“pôde-se observar, também, que os alunos se mostraram criativos na produção artística. Alguns grupos montaram cenários, utilizaram roupas diferentes, fizeram uso de imagens projetadas, montaram vídeos, tocaram instrumentos. Além disso, se preocuparam em rimar a letra da música, e em escrever os

(7) roteiros das peças. A escolha da apresentação dos trabalhos, por meio da música e do teatro, teve como intenção dinamizar as apresentações e a pesquisa."

Compreensões: Este excerto permite afirmar que os alunos reagiram muito bem à atividade, ficando profundamente motivados.

“a maioria dos estudantes conseguiu relacionar os termos pouco elaborados utilizados para responder ao Questionário 1, aos termos físicos propostos nas aulas empregados na resolução do Questionário 2 como 'convergente', 'divergente', 'espessa', 'curvatura' e 'foco' - de forma correta, coerente às definições aceitas pela comunidade científica.” "A utilização da oficina experimental como ferramenta pedagógica se mostrou eficiente por possibilitar que os estudantes interagissem com os conceitos durante a aula, testando as possibilidades, a fim de melhorar seus resultados, manipular os materiais, (8) observando a mudança da imagem projetada ou visualizada no caso das lentes, estimulou a criatividade dos estudantes e os motivou a aprender, a questionar e a se interessar pelos conceitos científicos presentes no simples fato de ver."

Compreensões: Não é possível afirmar com certeza quanto os alunos foram tocados e motivados pela abordagem. Contudo, aparentemente, eles aprenderam bastante com a atividade e foram capazes de responder as perguntas propostas e construir o experimento pedido. Assim, os alunos estão pelo menos burocraticamente motivados pela abordagem.

“Após a resposta do professor, alguns alunos ficaram inquietos, tentando entender porque existe frequência que não aciona o motor. Com o diálogo constituído, o professor pôde mostrar o experimento e os fenômenos de radiação eletromagnéticos envolvidos, possibilitando uma troca de conhecimento entre os próprios alunos.” "Destacamos ainda que, na discussão sobre o uso racional de energia elétrica

a partir da abordagem da aplicação do efeito fotoelétrico no cotidiano, os alunos participaram

(9) ativamente da discussão sobre as fontes e da utilização de energia elétrica, demostrando terem refletido acerca dos problemas enfrentados pelo uso irracional da energia e das soluções relativas aos problemas apresentados, o que pode ter propiciado uma formação científica articulada aos aspectos tecnológicos, sociais e ambientais."

Compreensões: Segundo o relato dos autores, “os alunos participaram ativamente” 
Trab. Informações extraídas e comentários

"A intervenção pedagógica permitiu estabelecer um diálogo entre o processo artesanal de produção de vinagre e o contexto escolar, considerando a cultura dos estudantes e as histórias de famílias. Algumas dessas histórias foram confrontadas quando os estudantes conheceram a teoria do processo, como por exemplo a necessidade de se manter o sistema fechado e isolado, sem contato com ar. Ao longo de toda a prática pedagógica os estudantes conversaram com familiares e a professora de química da escola, promovendo o confronte entre saberes escolares com saberes científicos e populares." "O tema sociocientífico de produção artesanal de vinagre promoveu debates sobre a educação química relacionando experiências cotidianas, imagens, uso da internet e entrevistas com familiares"

Compreensões: Não é possível afirmar, com certeza, qual o nível da motivação dos estudantes durante a abordagem, uma vez que não são mencionados detalhes de suas falas ou motivações. No entanto, devido ao fato dos estudantes terem seus conhecimentos e de suas famílias valorizados, é provável que eles tenham sido mais do que burocraticamente mobilizados.

"A abordagem de uma proposta baseada na perspectiva CTSA, proporcionou aos alunos o desenvolvimento de sua argumentação, e consequentemente do seu posicionamento crítico frente a situações-problemas, como pode ser observado na sequencia apresentada neste trabalho"

Compreensões: Não é possível inferir com certeza qual o nível de engajamento dos alunos diante da abordagem. É possível afirmar, apenas, que eles responderam bem à atividade, isto é, participaram com bom nível de argumentação no debate e mobilizaram vários dos conteúdos estudados.

"Ao final, os grupos fizeram uma tabela de valores de massa de açúcar nos produtos alimentícios, usando regra de três e calculadoras. Os resultados dos cálculos surpreenderam os estudantes, pois estes fazem consumo diário desses produtos." "Esse ambiente não-escolar se tornou um espaço educativo a partir da intencionalidade da prática pedagógica e da disposição de diálogo dos estudantes com o produtor rural”

Compreensões: Não é explicitada a forma como os alunos reagiram a atividade como um todo, mas a passagem citada, bem como o aprendizado dos alunos, verificado em vários momentos, nos dão indícios de que o engajamento dos alunos foi pelo menos parcial.

"O documentário chamou muito a atenção dos estudantes, pois faziam anotações e em nenhum momento houve conversas paralelas ou falta de interesse em assistir. No final queriam conversar e discutir sobre o que tinham visto" "as atitudes tomadas e vivenciadas em todas as etapas desse trabalho exprimem muita criatividade, criticidade e desenvolvimento na oralidade o que emerge uma considerável mudança de comportamento no processo de construção do conhecimento."

Compreensões: Os relatos feitos pelos autores nos indicam que os alunos foram bastante motivados pelas atividades.

"Na etapa de problematização, levantaram-se inicialmente alguns conhecimentos prévios dos alunos por intermédio das duas questões supracitadas na metodologia, e foi verificado que a princípio, os alunos não enxergavam um problema, daí a importância da construção de uma problematização em conjunto com os discentes, o que por sua vez implica em maiores engajamentos destes nas atividades propostas."

Compreensões: Não há elementos que possibilitem afirmar qual o nível de envolvimento dos alunos com as atividades realizadas.

"Embora o professor tivesse clareza da parte experimental, para os estudantes este procedimento consistiu num processo de descoberta. O debate teórico sobre o preparo das soluções produziu uma série de dúvidas e hipóteses sobre a influência de concentrações de íons metálicos no crescimento das raízes na batata doce." "O que poderia ser uma simples aula de soluções, nesse momento passou a ter um sentido maior para aqueles estudantes da classe de química. (com a ocorrência do desastre de Mariana)"

Compreensões: Embora não seja possível afirmar com certeza o grau de motivação dos alunos, eles parecem ter se envolvido bastante, principalmente no debate final que ocorreu logo após o desastre de Mariana. 


\begin{tabular}{cc}
\hline Trab. & Informações extraídas e comentários \\
\hline & $\begin{array}{c}\text { "Desde a divulgação na escola até o momento da realização da redação, observei grande envolvimento } \\
\text { e entusiasmo dos estudantes em participar do projeto. Todos realizaram as redações com seriedade e } \\
\text { compromisso" } \\
\text { Compreensões: A partir deste relato do professor, é possível afirmar que os alunos foram } \\
\text { profundamente motivados pelas atividades. }\end{array}$ \\
- Alunos pouco afetados pelas atividades (4) \\
- Alunos burocraticamente motivados pela abordagem $(2,3,8,11)$ \\
- Alunos parcialmente motivados, sem engajamento profundo $(1,5,8,10,11,12)$ \\
- Alunos profundamente motivados $(4,5,7,8,9,10,11,12,13,15,16)$
\end{tabular}

Fonte: Bondezan (2019).

\subsubsection{Atividades desenvolvidas em sala}

O eixo IV, denominado “Atividades desenvolvidas em sala”, detalha as atividades desenvolvidas pelos alunos ao longo das propostas didáticas relatadas. São cinco as categorias, diferenciando as atividades expositivas com passividade dos alunos; os levantamentos de concepções iniciais e as problematizações; as atividades de discussão em grupos, debates e aulas dialógicas; atividades de elaboração individual; e atividades de elaboração coletiva.

Devido ao fato dos alunos desempenharem posturas distintas em atividades extensas, um mesmo trabalho apresentou afinidade com mais de uma categoria. Para conciliar esta afinidade com mais de uma categoria, destacamos de maneira diferenciada ${ }^{31}$ na ficha de análise da tabela 15, os trechos que se aproximavam de cada uma dessas categorias.

Tabela 15 - Ficha de análise do eixo IV, “Atividades desenvolvidas em sala”

\begin{tabular}{cc}
\hline Trab. & Informações extraídas e comentários \\
\hline & Três momentos pedagógicos, construção em grupos do livro de pano passos da Pedagogia Histórico \\
Crítica: a) Prática social inicial do conteúdo; b) Problematização; c) Instrumentalização; d) Catarse; e) \\
Prática social final do conteúdo. Problematização do conteúdo: foram destacados o ambiente como \\
"nossa casa” e o planeta como referencial para a vida coletiva, assim como as dimensões \\
(1) $\quad$ conceitual/científica, social, econômica/política, histórico/filosófica e ético/ideológica. \\
Instrumentalização: aulas com datashow incluindo cenas do cotidiano, ecossistemas, componentes \\
bióticos e abióticos, etc. Catarse por meio de grupo focal. Prática social final: "Nesse momento cada \\
aluno manifestou por escrito sua nova atitude e sua proposta de ação para desenvolvimento de uma \\
postura cidadã”, detalhando o que precisa ser feito e como deve ser feito, associando com o conteúdo. \\
Essas ações são elencadas do ponto de vista individual.
\end{tabular}

31 Para esta diferenciação, usamos: i) sublinhado; ii) negrito; iii) sublinhado e negrito; iv) fundo cinza claro; e v) fundo cinza escuro. Ressaltamos, novamente, a ausência de juízo de valor nesta diferenciação, isto é, as atividades ressaltadas com negrito não são melhores ou mais indicadas do que as ressaltadas com sublinhado, por exemplo. 
Trab. Informações extraídas e comentários

"Adaptação dos momentos pedagógicos" "Na etapa de problematização inicial foi realizado um questionário/diagnóstico para identificar o conhecimento prévio das meninas quanto à experimentação em laboratório, questões de segurança, conceitos de Química associados ao preparo de soluções, produção de biodiesel e registro de atividades” "as alunas participaram, como ouvintes nas duas primeiras semanas das aulas práticas dos alunos de Engenharia” as alunas receberam

artigos sobre as práticas laboratoriais a serem realizadas e "o acompanhamento da leitura com 0 esclarecimento do processo". Na organização do conhecimento foi realizado o procedimento experimental e a leitura de artigos. "No último momento de aplicação do conhecimento, foram discutidas as questões associadas às dificuldades ocorridas para a produção em escala laboratorial e industrial, número de repetições de lavação do biodiesel com água, rendimento das reações, qualidade do biodiesel produzida, produção de sabão, entre outros aspectos."

"Os procedimentos metodológicos envolveram: uma intervenção didática com atividades de leitura, debate, elaboração e análise de painéis comparativos"

Foram desenvolvidos "questionamentos iniciais sobre a temática, leitura de texto, debate, e elaboração dos painéis comparativos (em dupla) pelos alunos."

“O debate intitulado ‘Quem é melhor? Combustível fóssil ou alternativo?’ teve início com a leitura do texto 'Biodiesel, possibilidades e desafios'”, com os alunos sendo divididos em um grupo que apoia os combustíveis fósseis e um grupo que apoia os combustíveis alternativos.

"A sequência (...) foi dividida em três etapas: apresentação do conteúdo (3 aulas), atividades práticas e discussões (6 aulas) e avaliação final (6 aulas).” "Na proposta didática, o professor apresentou 0 conteúdo, com uma aula expositiva, com o auxílio de simulações, disponíveis na plataforma PHET. Depois disso os estudantes foram estimulados a explorar o conteúdo, elaborando um projeto em grupo,

(4) trabalhos foram apresentados e discutidos.” Foi exigido dos grupos a escrita de um "mini relatório que contasse com todo o procedimento adotado por eles na execução e finalização dos trabalhos.” Nas apresentações dos alunos foram encontrados erros conceituais e "ao serem questionados com relação aos gráficos gerados pelo programa (Tracker) não sabiam relacionar aos conceitos estudados e pesquisados ao longo do trabalho."

Foram seis as atividades realizadas, incluindo uma palestra sobre resíduos sólidos, com todas as abordagens sendo discutidas a partir do contexto real da cidade e com os alunos elaborando "uma escrita reflexiva sobre o que a atividade lhes fez pensar"; construção de cartilhas sobre o lixo caseiro e discussão dos dados em roda de conversa; aulas expositivas e construção de composteira; visitação do aterro sanitário, com comparação entre as visões dos alunos antes e depois da visita; "elaboração de

um projeto de ação a partir da situação-problema apresentada com o objetivo de contribuir na transformação dos resíduos gerados com viabilidade econômica e ambiental considerando aspectos químicos, com os alunos sendo divididos em setores da sociedade; e apresentação do projeto de ação.

A sequência foi (...) iniciada com uma problematização inicial, baseada em Auler et al. (2005), que pretendia avaliar os conhecimentos prévios dos alunos sobre o funcionamento do motor de combustão e dos processos de conversão de energia envolvidos em seu funcionamento, além de

criar um contexto para estudo da Termodinâmica." "O segundo momento busca ampliar os

(6) objetivos de formação, possibilitando aos alunos a elaboração uma visão crítica das relações entre ciência, tecnologia e sociedade (...) (e) a Segunda Lei da Termodinâmica constituiu um contexto para discutir criticamente tecnologias baseadas na geração de energia térmica." "Nessa retomada da problematização inicial (terceiro momento), no contexto do ensino da Segunda Lei da Termodinâmica, os alunos foram solicitados a produzir um vídeo abordando o tema 'Degradação da energia e mobilidade urbana”" 
Trab.

Informações extraídas e comentários

Aulas "expositivas e vídeos. Dentre os assuntos acerca do conteúdo abordados em sala estão a descoberta/histórico da radioatividade; os efeitos das emissões radioativas; a natureza das radiações e suas leis; cinética das desintegrações radioativas; reações artificiais de transmutação; fissão e fusão nuclear; aplicações das reações nucleares e acidentes nucleares. Dentre os vídeos debatidos em sala estão: ‘Projeto Manhattan - construção da bomba'e 'Césio 137 - Linha Direta'.” Elaboração de música/paródia ou teatro em grupos a respeito de determinados subtemas, bem como apresentação, com recursos audiovisuais à disposição, ocorrida em duas aulas. "elaboração de um texto dissertativo em grupo acerca das impressões percebidas pelo conteúdo estudado, após as aulas e apresentações (...) (podendo) conter aspectos positivos e negativos, impressões pessoais e questionamentos sobre 0 assunto"

Realização de uma oficina experimental “dividida em três momentos pedagógicos”. Na problematização inicial, foi apresentado à turma um binóculo que após ser utilizado por todos os alunos, foi desmontado. A partir disso, foi discutido o motivo de ocorrerem os fenômenos de ampliação e diminuição das imagens. Na organização do conhecimento foram estudadas sistematicamente as características das lentes e das imagens formadas. Na aplicação do conhecimento foi proposto a realização em grupo de um projetor caseiro.

Na primeira aula foi realizada uma apresentação e aplicação do questionário introdutório. Nas duas aulas seguintes foram realizadas explicações do efeito fotoelétrico com uso de física quântica. Nas duas aulas seguintes foi feita a demonstração e análise do experimento "motor acionado por luz",

(9) contando com participação dos alunos e identificação de suas concepções alternativas. Na aula seguinte foram feitas discussões sobre a abordagem CTS (envolvendo, principalmente, exemplos de aplicação do fenômeno no cotidiano) e nova apresentação do experimento. Na última aula foi feita uma revisão de conteúdo e aplicação do segundo questionário.

Três momentos pedagógicos. Nas seis primeiras aulas foi realizada a problematização, com uma roda de conversa para identificar a tradição de produção de vinagre na cidade, a pesquisa de informações nutricionais em embalagens de vinagre, a exibição de um vídeo sobre a fabricação deste produto e uma avaliação individual. Nas nove aulas seguintes foi realizada a organização do conhecimento, com aulas expositivas e dialogadas, com a apresentação de slides e estudo com consulta à internet e a artigos científicos. Os assuntos estudados incluíram conceitos de química como funções orgânicas e reações de fermentação. Foram incluídas nas discussões alguns aspectos “socioeconômicos, socioculturais e socioambientais" do que era estudado. Nas seis últimas aulas foi realizada a aplicação do conhecimento, com a produção artesanal de vinagre, confecção de relatório das aulas práticas e "construção coletiva de um seminário em grupo". Segundo os autores, ao final da experiência "foram discutidas as questões socioeconômicas relativa a queda da qualidade do vinagre final, como valor de mercado, competição de processos artesanal e industrial, automação das indústrias, entre outros assuntos."

Antes da sequência didática em si, “foi realizada uma avaliação diagnóstica para verificar os

conhecimentos prévios dos alunos a respeito do tema.” no primeiro momento buscou-se "sensibilizar os alunos sobre a relevância da remediação ambiental”, com a leitura de reportagens sobre $\underline{\text { solos contaminados em um condomínio residencial. No segundo momento foram apresentados vídeos }}$ sobre áreas degradadas para que os estudantes conhecessem as principais substâncias que contaminam o solo. Ainda neste momento, os estudantes deveriam escrever uma redação individual com o tema “"como a contaminação do meio ambiente afeta a sociedade?'” No terceiro momento foi realizada uma aula expositiva para que os alunos entendessem como funcionam as principais técnicas de remediação. No quarto e último momento foram realizadas leituras de artigos e reportagens com consequências do acidente de Mariana e possíveis ações de remediação dessas áreas. Também neste momento da sequência, os alunos foram organizados em grupos de defesa e de acusação para um debate sobre a culpa das companhias Vale do Rio Doce e Samarco no desastre de Mariana. 
Trab. Informações extraídas e comentários

Nas três primeiras aulas de 100 minutos, foi realizada a problematização inicial, com uso de roda de conversa para destacar a importância do caldo de cana e da produção de açúcar para a região, pesquisar as informações nutricionais nas embalagens de alimentos, assim como calcular e reunir seu equivalente em açúcar, e exibição de um vídeo sobre o ciclo da cana-de-açúcar, com grande ênfase nos aspectos históricos. Nas quatro aulas subsequentes foi realizada a organização do conhecimento, com aulas expositivas e dialogadas, com a apresentação de slides e estudo com consulta à internet e a artigos científicos. Os conteúdos curriculares foram os processos de evaporação e cristalização, assim como "alguns aspectos socioeconômicos, socioculturais e socioambientais" e a "química do açúcar". Nas duas últimas aulas foi feita a visita a uma fábrica artesanal de açúcar, um relatório das aulas práticas e seminário.

No primeiro momento foi aplicado um questionário investigativo para identificar as concepções dos estudantes sobre energia e sua produção. No segundo momento os estudantes assistiram ao documentário “POWER: O poder por trás da Energia” e realizaram uma breve discussão, que não foi continuada por falta de tempo. No terceiro momento os estudantes realizaram pesquisas sobre os cientistas e demais acontecimentos mencionados no documentário. No quarto momento os estudantes foram divididos em grupos para estudo das principais formas de produção de energia elétrica a partir de aulas expositivas, textos disponibilizados pelo professor e em sites da internet. Ainda nesse momento

os alunos prepararam maquetes e seminários para sistematizar os conhecimentos apreendidos e
compartilhá-los com a sala. No quinto momento os alunos apresentaram para a sala seus seminários e
suas maquetes. No sexto momento foram confeccionados e distribuídos panfletos "para a comunidade
escolar destacando a importância das mudanças de posturas e participação crítica como cidadãos nas
questões relacionadas à produção e consumo de Energia, destacando a qualidade de vida das pessoas e
os impactos sociais, culturais, políticos e ambientais na sociedade.” Finalmente, no sétimo momento, o
questionário investigativo inicial foi reaplicado.

Na Problematização Inicial, com uma aula, os pesquisadores procuraram “um problema para ser explorado durante as atividades realizadas”, com uso de um questionário inicial, reconhecendo e valorizando as “concepções 'alternativas”” dos estudantes. Foram feitas duas perguntas, uma sobre o crescimento da população da Terra e outra sobre a possibilidade da ocorrência de prejuízos na busca por alimentar a população do planeta. Leitura do texto intitulado "A Indústria

Alimentícia” e a realização de um debate guiado por cinco questões. Na Organização do

(14) Conhecimento, em uma aula, foi realizada uma experiência para a determinação de vitamina C em diferentes amostras de sucos, com o auxílio da tintura de iodo. Na Aplicação do Conhecimento, com duas aulas, os alunos elaboraram uma dissertação sobre os aspectos que envolvem a produção de alimentos para suprir as necessidades da população, se valendo, para isso, de três pequenos textos, sobre o direito da população à alimentação, o uso de agrotóxicos em plantações e o desenvolvimento de alimentos transgênicos. Ao final, os alunos responderam a um questionário sobre suas concepções de "educação cidadã e das atividades trabalhadas."

Na problematização inicial, com quatro aulas, foi exibido o documentário sobre a produção do aço a partir do minério de ferro, assim como um debate guiado pela leitura de artigos sobre as reações de oxidorredução para a produção de ferro e uma avaliação individual. Na organização do conhecimento, com 6 aulas, foram ministradas aulas expositivas sobre conteúdos físico-químicos, planejado o

(15) experimento do crescimento das raízes de batata doce quando em contato com soluções de diferentes concentrações de diferentes metais e realizado um relatório da primeira fase. Na aplicação do conhecimento, com 6 aulas, os estudantes realizaram em grupos de 5 a 7 alunos o experimento anteriormente planejado, assim como uma roda de conversa sobre o desastre de Mariana, 0 associando com a experiência realizada e um relatório sobre o experimento. 


\begin{tabular}{|c|c|}
\hline Trab. & Informações extraídas e comentários \\
\hline (16) & $\begin{array}{l}\text { Na Prática Social Inicial os estudantes foram selecionados para participar do projeto por meio de uma } \\
\text { prova com o tema “Educação Alimentar”. Na Problematização os alunos estudaram a Educação } \\
\text { Alimentar participando de atividades expositivas que destacaram a interdisciplinaridade dos assuntos. } \\
\text { Na Instrumentalização os estudantes planejaram a visita a espaços de produção alimentar e a } \\
\text { construção de monografias. Foram escolhidos os locais de visitação e a construção de roteiros para a } \\
\text { coleta de informações. Na Cartase os estudantes visitaram os locais de produção alimentícia. } \\
\text { Na Prática Social Final os estudantes participaram de rodas de conversa com o intuito de "sintetizar } \\
\text { as etapas realizadas ao longo do semestre, com a construção social de uma pequena monografia } \\
\text { desenvolvida na perspectiva da aprendizagem colaborativa. Cada grupo apresentou um pequeno } \\
\text { resumo das etapas vivenciadas durante o desenvolvimento do projeto, orientadas por algumas } \\
\text { perguntas do professor.” }\end{array}$ \\
\hline & 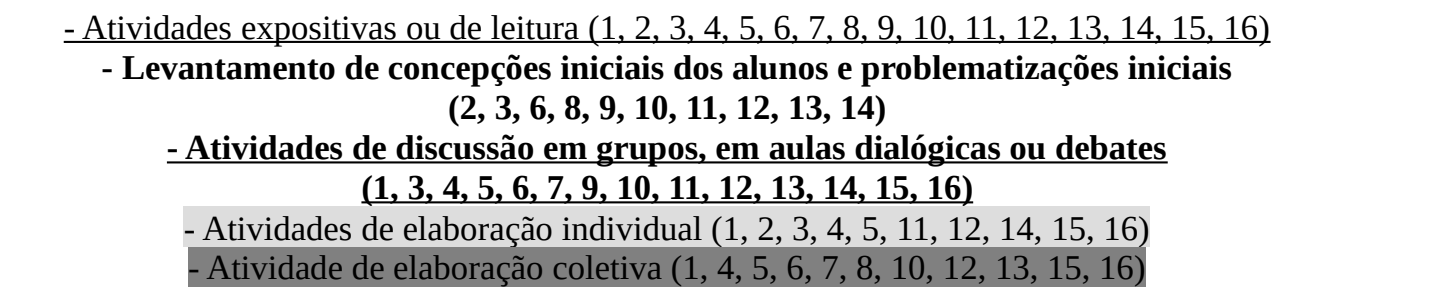 \\
\hline
\end{tabular}

Fonte: Bondezan (2019).

\subsubsection{Participação na sociedade que os alunos desenvolvem}

O eixo V, "Participação na sociedade que os alunos desenvolvem”, também detalha as atividades desempenhadas pelos alunos, mas tendo como foco a cidadania e a forma como ela é incentivada. As quatro categorias deste eixo apresentam de maneira gradativa a cidadania incentivada, diferenciando as atividades que não se relacionavam diretamente com a vida em sociedade, aquelas que se relacionavam com a cidadania de maneira individual e limitada, aquelas que se relacionavam com a vida em sociedade de maneira individual e ativa, e aquelas que incentivavam ações coletivas e ativas.

A tabela 16, a seguir, contém a ficha de análise do eixo V.

Tabela 16 - Ficha de análise do eixo V, "Participação na sociedade que os alunos desenvolvem"

Trab. Informações extraídas e comentários

“Os alunos compreenderam a importância de criar esse livro como forma de perpetuar a passagem de cada um deles pela escola, uma vez que o mesmo passará a fazer parte do acervo da biblioteca da Instituição.”

(1) Compreensões: A proposta é tida como possuindo relação com a ação na sociedade na forma de um livro que perpetuará a passagem dos alunos pela escola. Além deste livro de pano com relação um tanto indireta com a cidadania, temos também a "Prática Social Final”, em que os alunos são incentivados a mobilizar o que precisa ser feito e como essas ações serão feitas. Vale a pena destacar, porém, que essas ações devem ser pensadas em um nível individual. 
Trab. Informações extraídas e comentários

“as alunas foram instigadas a desenvolverem competências e habilidades como: autonomia, comunicação, domínio e responsabilidade” “porém alguns aspectos como tomada de decisão e anotações para posterior análise crítica dos resultados necessitariam mais situações para ocorrer o desenvolvimento dessa competência.” Ao final da prática experimental, as alunas foram incentivadas a realizar algumas variações nos reagentes da reação. "Esta ação promoveu a discussão sobre a necessidade de realização de um planejamento experimental (não efetuado) para determinar estatisticamente a melhor proporção biodiesel produzido, com gasto mínimo de reagente e menor tempo operacional possível.”

Compreensões: Como demonstrado pelos dois primeiros excertos, presentes no resumo do trabalho, todas as atividades realizadas foram capazes de preparar as alunas para as atividades laboratoriais, porém incapazes de proporcionar a tomada de decisão. O último excerto parece ser o mais próximo que a atividade chegou de uma prática cidadã, mas, aparentemente não foi realizada a conexão entre os diferentes processos de síntese do biodiesel e os impactos que possuem na sociedade e no ambiente.

“Um aspecto observado foi o fato das questões científicas terem sido pouco ressaltadas pelos alunos. (...) não identificamos nos painéis comparativos relações desses aspectos com os conceitos químicos neles envolvidos. Contudo, era esperado que os alunos estabelecessem relações entre conceitos químicos e a temática dos combustíveis fósseis e alternativos, dado que o professor já havia ministrado o conteúdo de termoquímica abordando conceitos químicos de energia de ativação, entalpia de reações etc., com os mesmos."

Compreensões: Os conteúdos abordados nos painéis comparativos sobre a QSC Política e econômica, como a "Viabilidade política” e a "Alteração de impostos incentivo de produção" foram apontados por menos de 30\% dos painéis. A nosso ver, estas dimensões são aquelas que mais se aproximam de uma compreensão global e estrutural, distante das compreensões puramente individuais. Um contraargumento é o excerto "Portanto, podemos dizer que as questões sociocientíficas mais abordadas pelos alunos sobre a temática Combustíveis fósseis e alternativos foram as de dimensão ambiental e atitudinal relativa aos valores e atitudes. Este resultado parece sinalizar uma compreensão por parte dos alunos de relações de causa e efeito entre conservação /degradação do meio ambiente e as ações e atitudes humanas. Este aspecto é evidenciado quando os alunos mencionam os efeitos dos combustíveis fósseis e dos combustíveis alternativos para a sociedade atual e para as gerações futuras, seus agravos na natureza e indicam a adoção de medidas individuais e coletivas que colaborem o uso consciente desses produtos.” As próprias autoras apontam, também, que os alunos não realizaram uma conexão entre a atividade desenvolvida e os conteúdos científicos estudados nas aulas anteriores.

Compreensões: A atividade se voltou com mais atenção ao uso de tecnologia e da experimentação em sala de aula, incentivando um protagonismo dos estudantes, com a confecção de vídeos de experimentos e a apresentação de seminários. A cidadania propriamente dita, contudo, pareceu um tanto distante das práticas realizadas em sala.

“A palestra além de proporcionar a alguns alunos o avanço na capacidade de questionar e de levantar hipóteses, também demonstrou-se eficiente quanto a abordagem da temática na percepção social.”

Compreensões: Durante as diversas atividades os alunos desempenharam diferentes tarefas que se

(5) relacionam de maneiras distintas com sua ação em sociedade. Tanto na construção das cartilhas sobre o lixo, quanto na elaboração do projeto de ação e sua apresentação, os alunos assumiram papel bastante ativo e engajado, bastante próximos da cidadania almejada pelos autores. 
Trab.

Informações extraídas e comentários

“Após a problematização inicial, o desenvolvimento da sequência, tendo o livro didático como o principal recurso cria uma descontinuidade, que não explora todas as possibilidades da tecnologia do motor de combustão, em termos do desenvolvimento conceitual. A nosso ver, tal fato refletiu negativamente na motivação dos estudantes e nas relações que efetivamente foram capazes de estabelecer entre a tecnologia, seus usos e os conceitos da termodinâmica.”

(6) Compreensões: A prática em sociedade, embora seja incentivada em todos os momentos da abordagem, é de maneira mais ativa na confecção de vídeos, que não foi detalhada. Mesmo assim, a mobilização de conhecimentos científicos para abarcar a situação em questão é essencial para a prática cidadã e bastante incentivada. Os próprios autores apontam, porém, que o livro didático, tido como principal recurso mesmo após as mudanças metodológicas, se configurou como uma limitação como fonte de informação para solucionar a problemática do transporte nas grandes cidades.

“A análise do trabalho evidencia que o que prevalece nas produções dos alunos é o conhecimento científico (vocabulário e exemplos), certamente por influência da própria proposta e, também, do contexto escolar. Nesse sentido, destaca-se a importância de inserirmos, também em nossas aulas discussões relacionadas às perspectivas mais criticas de racionalidade científica, a exemplo das limitações da ciência; às implicações do desenvolvimentos tecnológico e à importância da participação social. Ou seja, no caso aqui apresentado, as aulas estiveram centradas na abordagem do conhecimento científico, da forma como está presente no livro didático adotado pela escola, sem questionamentos

(7) associados ao desenvolvimento científico-tecnológico e suas implicações/relações com a sociedade.

Certamente, essa abordagem influenciou as produções dos alunos, em especial os textos elaborados ao final das atividades, que estiveram centrados no conhecimento científico."

Compreensões: Na atividade desenvolvida os estudantes foram incentivados a desempenhar tanto posturas passivas nas aulas expositivas, quanto posturas mais ativas nas produções autorais. Contudo, essas posturas mais ativas, mesmo possibilitando um maior protagonismo e uma ação em sociedade, segundo os próprios autores, acabaram ficando muito restritas aos conteúdos curriculares, tal qual as aulas expositivas, não sendo observadas manifestações mais críticas nas produções dos alunos.

“A atividade proposta consistiu na realização de uma oficina experimental, elaborada com o objetivo de servir como ferramenta para a observação, coleta de dados e análise do processo de construção do conhecimento e alfabetização cientificamente dos estudantes.”

Compreensões: Apesar da discussão teórica bastante rica no que diz respeito à cidadania, a proposta como um todo deu bastante atenção à elaboração de experimentos, investigativos ou não.

A sexta aula foi "dialogada com discussões sobre a abordagem CTS e nova apresentação do experimento" em que "o professor utilizou novamente o experimento para mostrar aos alunos sua aplicação em equipamentos tecnológicos, como por exemplo: no acionamento de portas automáticas, na interrupção de motores prevendo acidentes, na iluminação de ruas, em sensores eletrônicos de presença, entre outros. Nessa aula, o professor possibilitou a discussão dos fenômenos físicos e os alunos assumiram uma postura ativa durante o diálogo, levantando dúvidas e trazendo seu conhecimento prévio sobre o assunto.” “por meio de questões associadas à importância da aplicação dos conceitos de radiação eletromagnética e energia para o desenvolvimento tecnológico aplicado em aparelhos eletrônicos utilizados na sociedade. Usamos como exemplo o sistema das luminárias nos postes que opera de acordo com o efeito fotoelétrico, em que os alunos puderam debater sobre os pontos positivos e negativos desse tipo de iluminação.”

Compreensões: O excerto acima contém a atividade realizada pelos alunos com abordagem CTS, segundo os autores. É possível perceber, assim, que a abordagem CTS, para os autores, estaria próxima ao cotidiano dos alunos e ao fazer experimental com protagonismo deles. Os alunos debatem sobre os pontos positivos e negativos das luminárias movidas a painel solar, talvez de maneira pontual. 
Trab. $\quad$ Informações extraídas e comentários

“foram discutidas as questões socioeconômicas relativa a queda da qualidade do vinagre final, como valor de mercado, competição de processos artesanal e industrial, automação das indústrias, entre outros assuntos." "houve uma discussão sobre o destino dos efluentes desses processos bioquímicos. (...) haverá rejeitos de bagaço de cana, que podem ser utilizados em fornos. Quando há destilação do fermentado do vinho, rico em álcool em álcool etílico, o vinhoto é o principal rejeito do processo, que pode comprometer o sistemas hídricos e lençol freático. (...) aproveitamento de vinhoto como adubo orgânico em lavouras de hortaliças (...) a produção de vinagre pode gerar material gelatinoso, rico em colônias de bactérias (...), que também pode ser utilizado como adubo ao final do processo.”

Compreensões: Há certamente uma preocupação com o ambiente, com a necessidade de se diminuir os danos causados pelos subprodutos da produção do vinagre. Esta preocupação, porém não tenta incluir os órgão governamentais reguladores, ou investigar as implicações mais diretas à economia e à saúde dos habitantes.

Atividades expositivas que incentivavam os alunos a compreenderem os vários aspectos da natureza e a remediação na tentativa de minimizar os impactos causados pela ação humana. Debate sobre a culpa da Samarco no desastre de Mariana.

(11) Compreensões: As primeiras atividades realizadas pareceram ter relação um tanto indireta com a cidadania, não incentivando uma relação coletiva com a sociedade. A última atividade, o debate sobre o desastre de Mariana, por outro lado, incentivou que os alunos se posicionassem de maneira crítica e coletiva perante a temática ambiental.

“Sadler (2011) ressalta que as práticas escolares usando questões sociocientíficas (...) pode promover debates a partir de experiências de laboratório, experiências cotidianas, imagens, com a ajuda da internet e de visitas guiadas. Reis e Galvão (2008) sugerem o uso de questões sociocientíficas para provocar discussões incluindo conteúdos de ciências de natureza articulados as questões socioculturais, socioambientais, sociofilosóficas, socioeconômicas, entre outras, de tal maneira que as pessoas envolvidas no debate sejam forçadas a se posicionar, proporcionando reflexão sobre conceitos, crenças, valores, mitos etc." “Também foram abordadas as questões socioeconômicas em relação ao Brasil e ao mundo, como a produção sazonal de açúcar, o valor de mercado do açúcar, competição para a produção de álcool etílico, desemprego, automação das indústrias, entre outros assuntos.”

Compreensões: Há, certamente, um desejo dos autores de realizar um diálogo entre o conhecimento científico e suas múltiplas relações com a sociedade. Estas relações com a sociedade parecem ser apenas em nível individual e pouco ativo, a exceção da última discussão.

“construção de maquetes e montagem de seminários sobre: usina hidrelétrica, usina nuclear, usina eólica e usina termoelétrica; apresentação de seminários e maquetes; confecção e distribuição de

folders sobre o consumo consciente de energia e o aproveitamento das energias renováveis” “Assim, prevalece mesmo que seja intrinsicamente, a visão positivista da ciência e da tecnologia que o progresso da qualidade de vida está relacionado à economia, a maioria não se preocupa em tomar

decisões somente pelos benefícios da produção de energias renováveis para a sua qualidade de vida e do planeta”

Compreensões: Está bastante claro que os alunos agem de várias maneiras visando a participação em sociedade. Principalmente na confecção e distribuição de folders os alunos agem de maneira coletiva e ativa. Pela análise dos dados, porém, parece que a compreensão dos estudantes sobre energia, sua

forma de obtenção e as ações que podemos tomar não foram suficientemente problematizadas, ainda estando restritas a níveis pouco críticos.

“é de suma importância (...) levar em conta os conhecimentos prévios trazidos pelos alunos para a sala de aula. Assim sendo, foram levadas aos alunos duas questões que os instigassem a encontrar um problema a ser solucionado por meio do conhecimento científico e da sua função como cidadão atuante em uma sociedade” "Como resultado desse debate, chegou-se à conclusão de que a indústria alimentícia veio ao encontro da mudança vivenciada pela sociedade, como o êxodo rural e a

necessidade de maior produção de alimentos, o que, no entanto, implica em aspectos negativos como a perda de nutrientes essenciais para a saúde humana devido aos processos industriais.”

Compreensões: A cidadania é colocada em prática na forma de informação sobre as várias dimensões que dizem respeito à alimentação e ao consumo de alimentos processados. 


\begin{tabular}{|c|c|}
\hline rab. & Informações extraídas e comentários \\
\hline (15) & $\begin{array}{c}\text { “Os debates (...) abordaram questões como as atividades de mineradoras, especialmente a Vale que } \\
\text { atua no Estado do Espírito Santo e Minas Gerais, a produção e consumo de batata doce no Brasil e no } \\
\text { Estado do Espírito Santo, a contaminação de metais pesados no sistemas hídricos que podem } \\
\text { comprometer a qualidade da água consumida em casa, e o consumo de suplementos alimentares na } \\
\text { alimentação humana para melhorar a qualidade de vida.” “O clímax dos debates foi alcançado (...) após } \\
\text { o acidente da Samarco, com os impactos ambientais na bacia hidrográfica do Rio Doce (...) que } \\
\text { desaguou a lama de rejeitos concentrados de metais pesados, causando danos ambientais ao Rio Doce, } \\
\text { abrangendo mais de } 200 \text { municípios” "houve relatos das quantidades de peixes mortos em decorrência } \\
\text { do acidente na bacia hidrográfica” } \\
\text { Compreensões: A participação em sociedade realizada pelos alunos parece ter sido limitada, pelo } \\
\text { menos nos primeiros momentos da atividade, embora pareça ser mais evidente nos momentos finais. As } \\
\text { várias discussões realizadas diante do desastre de Mariana se dedicaram a se dar conta do ocorrido, sem } \\
\text { questionar as ações da mineradora e sem procurar medidas para evitar tragédias semelhantes. }\end{array}$ \\
\hline (16) & $\begin{array}{l}\text { “Depois que a gente foi na vigilância sanitária eu comecei a ver as coisas meio que diferentes, pois } \\
\text { antes eu não observava, tipo, a temperatura que tava o armazenamento dos produtos que colocavam lá, } \\
\text { comprava o queijo com aquela aguinha de cor diferente e não sabia o que que era aquilo e hoje não, eu } \\
\text { já observo e já sei o que é o certo e o que é o errado, e tipo, do jeito que eles estão armazenando se está } \\
\text { certo, ou alguma coisa que eles estão deixando ali que vai prejudicar a gente” } \\
\text { Compreensões: As atividades realizadas pelos alunos acabaram por ficar um tanto distantes da } \\
\text { cidadania. A prática social final consistiu em uma roda de conversa em que os alunos avaliaram o que } \\
\text { aprenderam, sendo que os conhecimentos adquiridos são restritos à produção, consumo e conservação } \\
\text { de alimentos. }\end{array}$ \\
\hline & $\begin{array}{l}\text { - Não diretamente relacionada com a vida em sociedade ou extremamente limitada }(2,4,8,9,16) \\
\text { - Relacionada com a vida em sociedade de maneira individual e limitada }(3,7,10,12,14,15) \\
\text { - Relacionada com a vida em sociedade de maneira individual e ativa }(1) \\
\text { - Relacionada com a vida em sociedade de maneira coletiva e ativa }(5,6,11,13)\end{array}$ \\
\hline
\end{tabular}

Fonte: Bondezan (2019).

\subsubsection{Contexto da prática docente}

O eixo VI, intitulado “Contexto da prática docente”, tem como objetivo caracterizar os diferentes contextos em que se dá a atuação docente, contando com dois blocos. O primeiro deles possui três categorias a respeito da duração da atividade relatada, as diferenciando entre extensas, isto é, que se desenvolvem em mais de cinco aulas; pontuais, em menos de cinco; e atividades que se dedicam a contextos não formais. O segundo bloco possui duas categorias que distinguem uma influência maior ou menor do currículo escolar pré estabelecido.

A tabela 17, a seguir, contém a ficha de análise do eixo VI.

Tabela 17 - Ficha de análise do eixo VI, "Contexto da prática docente”

\begin{tabular}{cc}
\hline Trab. & Informações extraídas e comentários \\
\hline$(1)$ & Ensino Médio em escola pública em 16 aulas. Disciplina de Biologia \\
\hline$(2)$ & Duas meninas do primeiro ano do Ensino Médio em escola pública, em horário fora de aula \\
\hline
\end{tabular}


Trab. Informações extraídas e comentários

(3) Segunda série do Ensino Médio, Camaragipe Pernambuco. 26 alunos. Duas aulas de Química

Escola pública de Uberlândia, quinze aulas. Oito turmas, com 45 alunos cada de Primeiro Ano de Ensino Médio

"a presente pesquisa busca contribuir com o ensino de química, no ensino médio, com o desenvolvimento durante o Estágio Supervisionado IV do curso de Licenciatura em Química da UNIPAMPA (Bagé-RS)"

(5)

Compreensões: Embora a prática em sala foi descrita com grande riqueza de detalhes, não foi explicitado o número de aulas usadas. Pelo número de atividades, porém, o número mínimo de aulas gastas deve ter sido superior a dez.

(6) Escola técnica federal, sete turmas de Ensino Médio, num total de 186 alunos Compreensão: Não foi especificado o número de aulas em que a atividade foi desenvolvida.

Segundo ano de Ensino Médio em escola pública federal em Brasília. "Em relação ao ensino de Química nessa escola, percebem-se algumas dificuldades, como o excesso de conteúdo; a ênfase no 'formulismo matemático'; dificuldades por parte dos alunos em compreender alguns fenômenos e correlacioná-los ao cotidiano; pequeno número de aulas práticas" "a escola mantém um currículo extenso, com diversos tópicos, padronizado para todas as escolas da rede federal a que está submetida" A proposta foi aplicada em 14 aulas a 9 turmas e a 204 alunos.

Compreensões: A atividade foi desenvolvida em um contexto usual e notadamente marcado pelo currículo pouco flexível. Este fato não impossibilitou uma atividade voltada à cidadania, mas dificultou a discussão de aspectos mais críticos. Esta atividade se desenvolveu em 14 aulas, havendo tempo suficiente para cada uma de suas etapas.

"estudantes do segundo ano do ensino médio de uma escola da rede estadual de ensino situada no Distrito de Mosqueiro/PA" "A oficina experimental foi aplicada em sala de aula com duração de duas horas" A turma era composta por 12 alunos.

(8)

Compreensões: A atividade foi realizada em duas aulas em ensino regular e com aparente ausência de rigidez curricular, mesmo que os autores tenham seguido o currículo.

"alunos de uma sala da 3a série do Ensino Médio, em uma escola da rede estadual de ensino localizada no Vale do Paraíba. Essa sequência foi aplicada pelo professor de física, em um total de sete aulas” 35

(9) alunos, aula de Física

Compreensões: A proposta foi desenvolvida em sete aulas em contexto regular e não parece ter sofrido grande influência do currículo da escola.

"escola da Rede Federal de Educação Profissional e Tecnológica do Estado do Espírito Santo, envolvendo duas turmas com 35 estudantes de ensino técnico de nível médio.” disciplina de química num total de 21 aulas.

Compreensões: As atividades se desenvolveram em várias aulas e não foi mencionada nenhuma pressão do currículo pré estabelecido.

“45 alunos da $1^{\text {a }}$ série do Ensino Médio de uma escola estadual de São Paulo”

Compreensões: Embora não tenha sido mencionado o número de aulas usadas nas atividades, é

(11) possível supor que elas tenham sido pelo menos seis, devido ao grande número de tarefas realizadas. A rigidez curricular também não foi mencionada.

"A intervenção de ensino envolveu 15 estudantes de ensino médio da Rede Estadual de Educação Básica do Estado do Espírito Santo.” Foram realizadas um total de 18 aulas

Compreensões: Foram utilizadas 18 aulas para a realização das atividades. A rigidez curricular não foi mencionada.

"vinte e sete alunos do terceiro ano do ensino médio de uma escola pública do município de Reserva/PR"

(13) Compreensões: Não é especificada a quantidade de aulas utilizadas para a realização das atividades relatadas no trabalho, contudo, essa quantidade parece ser elevada. A influência curricular não foi mencionada. 


\begin{tabular}{cc}
\hline Trab. & Informações extraídas e comentários \\
\hline & "escola estadual Adahir Guimarães Fogaça, localizada na região norte da cidade de São José do Rio \\
(14) & $\begin{array}{c}\text { Preto, com três turmas do } 3^{\circ} \text { ano do Ensino Médio, sendo duas turmas matutinas e uma noturna, e uma } \\
\text { turma noturna do 3o Ano da Educação de Jovens e Adultos (EJA).” Foram realizadas } 4 \text { aulas no total. } \\
\text { Compreensões: Foram realizadas } 4 \text { aulas e o currículo como limitador não foi mencionado }\end{array}$ \\
\hline
\end{tabular}

“O conteúdo programático de química previsto para o segundo ano do ensino médio inclui soluções, equilíbrio químico, reações ácido-base e de oxirredução, entre outros” A atividade foi desenvolvida em duas salas do segundo ano do Ensino Médio de uma escola pública do Espírito Santo, envolvendo 48 alunos. As atividades foram desenvolvidas em um longo intervalo de tempo (16 ou 30 horas, conforme divergência no trabalho)

Compreensões: Mesmo com divergência quanto a duração das atividades realizadas, certamente o número de aulas foi grande. Além disso, a influência do currículo não foi mencionada como cerceadora ou castradora.

Participaram desta atividade 16 estudantes com idades entre 14 e 18 anos, que frequentaram as (16) atividades no contraturno do Ensino Médio Regular. A prática que seguiu as cinco etapas da Pedagogia Histórico-Crítica ocorreu em um longo espaço de tempo.

- Ensino formal em várias aulas (1, 4, 5, 6, 7, 9, 10, 11, 12, 13, 15)

- Ensino formal em poucas aulas $(3,8,14)$

- Ensino não formal $(2,16)$

- Maior rigidez curricular $(6,7)$

- Menor rigidez curricular (1, 2, 3, 4, 5, 8, 9, 10, 11, 12, 13, 14, 15, 16)

(não exclusivas)

Fonte: Bondezan (2019).

\subsubsection{Cidadania apresentada pelos autores}

O eixo VII, finalmente, denominado “Cidadania apresentada pelos autores”, identifica as concepções de cidadania mencionadas pelos autores ao longo do texto, mesmo que elas não sejam colocadas em prática. Estas concepções foram reunidas em cinco categorias: Alfabetização Científica, CTS(A) e Questões como motivadoras, associadas ou não à cidadania; cidadania na forma de "interpretação de mundo" e "tomada de consciência", se aproximando das Percepções; cidadania associada à “ética”, “valores” e "pensamento crítico”, se aproximando dos Questionamentos; cidadania como "posicionar-se frente" a algo, se aproximando do Compromisso Social, mas sem se transformar em ação concreta; e cidadania na forma de "resolução de problemas" ou “tomada de decisão", se aproximando do Compromisso Social propriamente dito.

Além dessas concepções de cidadania que foram identificadas e destacadas de maneira diferente nas fichas de análise de cada um dos textos, diferenciamos, também, outras 
expressões $^{32}$. Essas expressões incluem termos um tanto vagos, como a "liberdade de questionar” dos alunos e o “abandono de uma postura passiva por uma postura crítica”, conceitos que podem estar associados, de fato, apenas ao fazer experimental e a atividades em grupo, se afastando da cidadania em si. Também faz parte das expressões diferenciadas termos como "socioeconômicas”, “sócio-históricas”, “sociopolíticas” e “socioculturais”, usados sem um maior detalhamento.

A tabela 18, a seguir, contém a ficha de análise do eixo VII.

Tabela 18 - Ficha de análise do eixo VII, “Cidadania apresentada pelos autores”

Trab.

Informações extraídas e comentários

\begin{tabular}{|c|c|}
\hline (1) & $\begin{array}{l}\text { Alfabetização Científica com Pedagogia Histórico Crítica } \\
\text { “cidadania, capaz de criar no educando, uma visão holística suficientemente sólida para um embate } \\
\text { responsável e criativo, frente aos desafios de um mundo globalizado,” } \\
\text { "a leitura de um mundo ao redor acontece antes da leitura pela palavra” (Freire) } \\
\text { a ““população disponha de conhecimentos científicos e tecnológicos necessários para se desenvolver na } \\
\text { vida diária, ajudar a resolver os problemas e as necessidades de saúde e sobrevivência básica, tomar } \\
\text { consciência das complexas relações entre ciência e sociedade”” }\end{array}$ \\
\hline (2) & $\begin{array}{l}\text { “no intuito de incentivá-las a ingressar em carreiras de Ciências Exatas e Tecnológicas” “Uma } \\
\text { alternativa para” desenvolver a aprendizagem significativa e a motivação dos alunos “baseado nas } \\
\text { teorias construtivistas, seria a alfabetização científica (AC), que visa formar cidadãos conscientes para } \\
\text { exercerem seus direitos na sociedade moderna e requer o domínio de conceitos científicos e } \\
\text { conhecimento sobre a natureza da Ciência, bem como disposição para imersão em problemas } \\
\text { científicos” "a Alfabetização Científica e Técnica (ACT) como uma estratégia pedagógica e } \\
\text { epistemológica para abordagem interdisciplinar do ensino de Ciências por meio de projetos, } \\
\text { explicitando a necessidade de um contexto, próximo à realidade do aluno, que possibilite desenvolver } \\
\text { autonomia, aquisição de competência de comunicação, domínio e responsabilidade.” }\end{array}$ \\
\hline (3) & $\begin{array}{l}\text { “o processo de obtenção e de utilização de combustíveis fósseis produzidos com recursos não } \\
\text { renováveis gerando reações químicas de grande potencial energético, e diferentes possibilidades de } \\
\text { utilização de combustíveis alternativos produzidos com recursos renováveis para as quais precisam ser } \\
\text { consideradas vantagens ambientais e suas relações com a viabilidade política, econômica, tecnológica e } \\
\text { sociocultural, etc. Além disso, a busca por fontes alternativas de energia é de grande importância para a } \\
\text { sociedade.” “Os resultados indicam que as questões sociocientíficas enfatizadas pelos alunos foram as } \\
\text { ambientais e atitudinais. Questões tecnológicas, econômicas, políticas, sociais e científicas tiveram } \\
\text { menor ênfase nas discussões. Contudo, elas precisam ser discutidas em sala de aula quando se trabalha } \\
\text { segundo a abordagem CTS, ou seja, quando se pretende fazer compreender as relações CTS visando } \\
\text { desenvolvimento de atitudes e valores para a tomada de decisão em situações que envolvam ciência e } \\
\text { tecnologia. Assim, aspectos ambientais e atitudinais abordados isoladamente não darão conta da busca } \\
\text { de soluções para os problemas da sociedade relacionados com ciência e tecnologia.” “Tomando por } \\
\text { base o objetivo de desenvolver nos alunos atitudes e valores para a tomada de decisão diante de } \\
\text { situações envolvam a ciência e a tecnologia” }\end{array}$ \\
\hline
\end{tabular}

32 Para a diferenciação das categorias, usamos: i) sublinhado; ii) negrito; iii) sublinhado e negrito; iv) fundo cinza claro; e v) fundo cinza escuro. Além destas categorias, destacamos as outras expressões utilizando negrito, sublinhado e fundo cinza escuro. 
Trab.

Informações extraídas e comentários

"Sabemos que as novas tecnologias fazem parte do dia a dia da sociedade moderna e que não são muito diferente no ambiente escolar, hoje os estudantes convivem a todo instante com esta evolução tecnológica que os coloca diante das tecnologias digitais." "Percebemos que o avanço das tecnologias digitais proporcionam aos estudantes experiências que o ambiente escolar tradicional não proporciona, geralmente as salas de aulas nas escolas são monótonas, desmotivadoras e entediantes, levando os estudantes a usarem os recursos digitais presentes em seus celulares (...) como ferramenta de passa tempo" "Nesta perspectiva apresentaremos uma proposta de ensino de física onde que faremos o uso de uma abordagem pautada CTS (Ciência, Tecnologia e Sociedade) que se faz presente e que venha a proporcionar um ambiente mais interativo e dinâmico.”

"Mas se aliarmos a prática experimental num enfoque mais CTS poderemos provocar um despertar

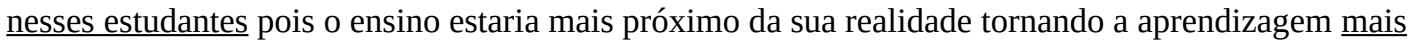
dinâmica e ativa. Podemos encontrar vários artigos dentro da literatura que comprovem este fato. Assim de acordo com (...): 'Os conhecimentos acerca da ciência numa perspectiva CTS que sejam eticamente orientados, contribuem para a construção de uma cidadania cultural, critica e ativa.’”

"Partindo desta premissa (dificuldades de aprendizagem dos estudantes possível de ser superada com

‘abordagem química por meio de temas relevantes'), surge o enfoque ambiental de resíduos sólidos que necessita ser discutido em sala de aula com o objetivo de contribuir para o desenvolvimento de um pensamento crítico no que se refere às questões sociais, econômicas e tecnológicas vinculadas a esta temática. No ensino de química, busca-se com o tema lixo desafiar os alunos a refletirem e participarem ativamente no processo democrático de tomada de decisões.” "compreende-se que explorar a temática lixo aliado aos conceitos químicos e a elementos do cotidiano, pode contribuir no desenvolvimento de cidadania e participação.” Processo educativo que "envolva o aluno ativamente, o desafie e o coloque em desequilíbrio para buscar soluções e tomar suas decisões frente a situações problemáticas reais.” "o currículo de ciências do ensino médio pode configurar-se como caminho para preparar o indivíduo a participar democraticamente na sociedade na busca de tomada de decisão para solução de problemas que envolvam aspectos sociais, tecnológicos, econômicos e políticos.”

“o movimento CTS tem colaborado para que a educação cientifica se consolide no propósito de formação como exercício de cidadania" "tomada de decisão na sociedade cientifica e tecnológica e o desenvolvimento de valores” “o movimento CTS no ensino de ciências contribuiu para a inserção de temas sociocientíficos, a promoção do engajamento em ações sociais responsáveis, a discussão de questões controversas e de problemas ambientais contemporâneos"

“o ensino de Química deve contribuir para que o aluno tenha condições para interpretar o mundo, questionar, analisar, se inserir de forma crítica nos fatos e acontecimentos com os quais se encontra.”

"o ensino de ciências deve favorecer o conjunto de relações entre o conhecimento científico, o tecnológico e suas implicações sociais, com o objetivo que o aluno estabeleça uma noção que lhe possibilite refletir criticamente sobre a Ciência, a Tecnologia e suas consequências, de forma a se posicionar frente aos problemas sociais.”

"possa realizar pesquisas científicas sendo capaz de criar e modificar o ambiente que o cerca. Nessa perspectiva a alfabetização científica, surge da necessidade de construir cidadãos capazes de intervir na sociedade, se apropriando dos conceitos científicos de modo que consigam interpretá-los, estabelecer uma relação crítica frente às problemáticas que os envolvem e aplicar seus conhecimentos de forma responsável e produtiva tanto em aspectos científicos como tecnológicos” "a alfabetização científica é definida como essencial no processo de formação do sujeito como cidadão, por meio dela a pessoa é capaz de incitar mudanças significativas, atuando ativamente na sociedade da qual faz parte.” "meio de instrução para o indivíduo compreender as decisões realizadas em sociedade, e poder participar de

debates públicos que envolvam ciência." "uma pessoa alfabetizada é capaz de incorporar essas técnicas influenciando seu meio.” 
Trab. Informações extraídas e comentários

““No diálogo, as ideias vão tomando corpo, tornando-se mais precisas. O conflito de pontos de vista aguça o espírito crítico, estimula a revisão das opiniões, contribui para relativizar posições [...]. É neste momento do diálogo e da reflexão que os alunos tomam consciência de sua atividade cognitiva, dos procedimentos de investigação que utilizaram aprendendo a geri-los e aperfeiçoá-lo.” “(nas) atividades investigativas (...) o estudante (...) percebe o seu papel fundamental na construção do conhecimento em aula, abandonando uma postura passiva e tornando-se crítico, adquirindo a liberdade de questionar, relatar acontecimentos e buscar as causas dessas relações, o que dá ao seu trabalho características de uma investigação científica." "Buscando um ensino interdisciplinar, o currículo de Ensino de Ciências

(9) vem abordando temas que envolvem tecnologia, sociedade e ambiente, com o intuito de que o aluno desenvolva, por meio da ciência, o pensamento crítico em relação a problemas sociais e ambientais enfrentados pela a sociedade que está inserido.” ““(i) A busca por um ensino que contribua para uma mudança da compreensão do status da ciência, que envolve preparar os estudantes para compreender o papel que a ciência e a tecnologia exercem na sociedade e vice-versa. (ii) O desenvolvimento de uma aprendizagem social, entendida como a formação de cidadãos capazes de utilizar os

conhecimentos escolares, que deixam de ser apenas científicos, já que envolvem questões mais humanistas e culturais, para se posicionar criticamente e decidir sobre questões relacionadas à ciência e à tecnologia."”

"De que maneira os aspectos tecnológicos, sociocientíficos, socioeconômicos, socioculturais e socioambientais podem ser entrelaçados pela temática ‘produção de vinagre’?” “as práticas devem

tratar inicialmente de problemas/temáticas sociocientíficas, seguidas de abordagens teóricas, abordagens práticas e, finalmente, debates com pessoas de notório saber.” “A educação CTS/CTSA, de acordo com Aikenhead (1997), quando é desenvolvida na perspectiva de estudos culturais de ciência transcultural, pode promover conexões de saberes na fronteira do conhecimento, ampliando a visão de mundo, contribuindo para eliminar preconceitos existentes na humanidade e conscientizar a população sobre o papel da ciência.”

“o principal objetivo de um currículo que contemple a CTSA é desenvolver a capacidade de tomada de

decisão e, além disso, enfatizar questões ambientais, visando à promoção da educação ambiental

(SANTOS, 2007).” “desenvolvendo também seu posicionamento crítico perante os problemas presentes em seu contexto social” "a remediação ambiental (...) apresenta potencial para o desenvolvimento da reflexão crítica, proporcionando uma educação problematizadora.” “a Educação Ambiental é considerada (...) como uma preocupação dos movimentos ecológicos com a prática de conscientização (...) assim como (...) envolver os cidadãos em ações sociais ambientalmente apropriadas.” “A perspectiva CTSA (...) fazendo com que os estudantes entendam com mais facilidade o papel da ciência em seu ambiente socioambiental (...) essa abordagem visa proporcionar aos discentes uma maior conscientização a respeito das relações entre Ciência, Tecnologia, Sociedade e Ambiente, rompendo com a imagem neutra da Ciência, desenvolvendo o posicionamento crítico e a tomada de decisão dos alunos frente a problemas existentes em seu contexto social.”

“Neste trabalho, focamos numa intervenção pedagógica de Ciências da Natureza, abordando estudos

culturais sobre a construção social da ciência e tecnologia, também chamado de educação (...) CTSA" "De acordo com Aikenhead (...), a educação CTS/CTSA é fruto da produção de

conhecimento científico e assume uma perspectiva interdisciplinar e transdisciplinar, tratada pelo autor como sendo a ciência transcultural, promovendo conexões de saberes na fronteira do conhecimento." "De que maneira os aspectos tecnológicos, sociocientíficos, socioeconômicos, socioculturais e socioambientais podem ser entrelaçados pela temática 'produção de açúcar’?” “O objetivo deste trabalho foi o de estudar os aspectos metodológicos de ensino e a educação CTS/CTSA promovida a partir da realização de uma sequência de ensino investigativo de química para debater a temática de produção de açúcar.” 
Trab.

Informações extraídas e comentários

“produção de energia elétrica e seus impactos ambientais, sociais, políticos e econômicos” "instigar os estudantes por meio do documentário a reconhecer as variadas formas de produção de energia e qual é a forma de produção de energia menos impactante na sociedade, levando-os a tomarem

algumas decisões em relação ao uso e à produção de energia.” “A maior preocupação do Ensino com o enfoque CTS é apresentar um ensino crítico e interdisciplinar que leve o estudante a uma alfabetização científica para que possa ter condições para participar efetivamente das decisões que envolvem questões sobre o desenvolvimento científico e tecnológico.” “Evidenciando discussões em busca do conhecimento que favoreça sua atuação como pessoas pensantes em relação às questões energéticas vivenciadas na presente realidade em que vive com capacidades e intenções de melhorar o mundo que o rodeia.”

“o aluno apropriando-se do conhecimento científico estará dando um passo a mais para se tornar um cidadão crítico na sociedade" "deve promover a curiosidade e o espírito crítico nos alunos” "Ao abordar a prática de experimentação problematizadora, uma linha tênue é traçada com o movimento CTSA (...); afinal, a problematização surge do cotidiano do sujeito, representando um obstáculo a ser superado pelo conhecimento científico” A CTSA tem “como principal meta preparar os alunos para o

(14) exercício da cidadania, em que, nesta perspectiva, a contextualização pode abordar desde questões do cotidiano, de cunho mais individual, até questões mais globalizadas (...), com a finalidade de valorizar a formação de indivíduos críticos e atuantes na sociedade moderna.” “"contribuir de fato para a construção de uma sociedade democrática, cujos membros sejam cidadãos conscientes e comprometidos com a própria transformação da sociedade."” “formação de cidadãos críticos e atuantes na sociedade, capazes de tomar decisões conscientes com base no conhecimento científico.”

"sejam utilizados temas sociocientíficos para discutir conteúdos de ciências articulados às questões morais, éticas, de valor, sobretudo, criar situações nas quais as pessoas sejam obrigadas a se

posicionarem" "No nosso caso, utilizamos a temática sócio-científica da influência da concentração de íons $\mathrm{Cu}, \mathrm{Zn}, \mathrm{Al}$ e Fe no crescimento de raízes de batata doce, a fim de produzir debates além dos conteúdos de química normalmente trabalhados (...) englobando (...) temáticas de saúde, problemas ambientais e tecnologia de alimentos"

“Morin (2011) ressalta que, para garantir uma educação para o futuro, com vistas a uma democracia e uma cidadania terrestre, exige um esforço interdisciplinar e transdisciplinar para que isso seja alcançado.” "De acordo com Sadler (2011), temas sociocientíficos são questões ou temas da sociedade que apresentam características socioeconômicas, sócio-históricas, sociopolíticas, socioculturais, éticas e socioambientais relativas à construção social da ciência e tecnologia, visando à formação de cidadãos ativos e emancipados." "envolvendo debates sobre questões cotidianas, como o tratamento de efluentes, tratamento de água, uso de agrotóxico na produção de alimentos, alimentos transgênicos, experiências científicas com uso de cobaias de animais, o controle de doenças infectocontagiosas”

- Alfabetização Científica, CTS(A) e QSC como motivadoras, associadas ou não à cidadania $(2,4,10,12)$

- Cidadania incentivada na forma do desenvolvimento de “interpretação de mundo" e “tomada de consciência”, se aproximando das Percepções $(1,2,7,8,9,10,11,13)$

- Cidadania como se dedicando à "ética", a "valores" e promovendo o "pensamento crítico", se aproximando dos Questionamentos $(3,4,5,6,7,8,9,11,13,14,15,16)$

- Cidadania como "posicionar-se frente” a algo, se aproximando do Compromisso Social, mas que ainda não

foi transformada em ação concreta em sociedade $(7,8,10,15,16)$

Cidadania na forma de "resolução de problemas”, "tomada de decisão”, "desenvolvimento de atitudes”, “embate responsável”, “exercer direitos”, se aproximando do Compromisso Social (1, 2, 3, 4, 5, 6, 7, 8, 11, 13, 14)

Fonte: Bondezan (2019).

Os sete eixos, suas categorias e suas fichas, descritos e apresentados neste capítulo, têm como objetivo identificar as principais influências nas atividades práticas voltadas à promoção da cidadania. A identificação, análise e discussão destas influências, a ser realizada no 
capítulo seguinte, é importante para que se compreenda as várias possibilidades de encaminhamentos que visam a cidadania.

Este processo será realizado de maneira articulada com os demais elementos apresentados ao longo desta dissertação, isto é, com auxílio das várias concepções de cidadania de maneira geral, das denominações recorrentes na Pesquisa em Ensino de Ciências, seus pressupostos teóricos e suas características mais comuns. 


\section{Capítulo 7 - As diferentes formas de promoção da cidadania na sala de aula}

As várias compreensões sobre cidadania, tanto na educação em geral, quanto no Ensino de Ciências de maneira específica, são refletidas e incentivadas pelos documentos reguladores e balizadores da educação e do ensino de ciências.

Além disso, as formas como a cidadania é pensada são diretamente incentivadas ou limitadas pelo contexto político e democrático em que estão inseridas, se traduzindo em práticas em sala de aula com maior ou menor liberdade. Dentro de um contexto em que inexista liberdade de expressão e com grande repressão a posicionamentos dissidentes, por exemplo, a proposição de atividades em sala que incentivem uma participação social que não a desejada pelo modelo vigente se torna bastante difícil.

Também nesta direção temos a concepção de Ciência adotada que, embora não diretamente ligada à cidadania em si, acaba interferindo nas abordagens em ensino de ciências visando a atuação dos alunos em sociedade. A adoção de concepções limitadas de Ciência podem, por exemplo, excluir a possibilidade de uma população mais ampla participar nos processos de tomada de decisão que envolvam a Ciência e a Tecnologia.

Dentre as concepções limitadas de ciência, temos aquelas que a consideram como neutra, livre dos interesses de cientistas, empresas e governos, e, ainda, concepções que a assumem como suficiente para resolver todos os problemas da humanidade e tendo os conhecimentos científicos como os únicos necessários para a tomada de decisão.

As quatro seções deste capítulo, a seguir, buscam compreender e sistematizar as formas como a cidadania é incentivada dentro do Ensino de Ciências, assim como a realização de uma aproximação com a prática docente.

A primeira seção se volta especificamente para as abordagens que aparecem de maneira recorrente na Pesquisa em Ensino de Ciências, descrevendo e destacando algumas de suas principais compreensões.

A segunda seção, por sua vez, aponta algumas das aproximações e afinidades de cada uma das abordagens preocupadas com a promoção da cidadania identificadas.

Na terceira seção são discutidos os resultados da segunda análise, apresentada no capítulo 6, dando especial atenção para os principais fatores que influenciam as práticas voltadas à promoção da cidadania. 
Finalmente, na quarta seção, os fatores influenciadores das práticas preocupadas com a cidadania são articulados na intenção de estreitar a distância entre as contribuições teóricas e a atuação dos professores na educação básica.

\subsection{As abordagens recorrentes na Pesquisa em Ensino de Ciências preocupadas com a cidadania}

As diferentes abordagens dentro do ensino de ciências que buscam incentivar a cidadania aparecem de maneira recorrente com denominações como Alfabetização Científica, Ciência, Tecnologia, Sociedade e Ambiente, Questões Sociocientíficas, Questões Controversas e Questões Socioambientais.

Essas três últimas denominações, isto é, as Questões Sociocientíficas, as Questões Controversas e as Questões Socioambientais, em nossas buscas, se mostraram muito próximas entre si, tanto do ponto de vista teórico, possuindo pressupostos em sintonia, quanto do ponto de vista empírico, com vários trabalhos fazendo menção a mais de uma delas. Elas foram reunidas, por estas razões, como parte de um grupo maior denominado Questões.

Cada uma das denominações, além de refletirem as várias compreensões de cidadania possíveis, não se constituem como um todo homogêneo, isto é, são, em si, um campo de disputa entre diversas visões de educação, encaminhamentos metodológicos e participação em sociedade.

Apresentamos, a seguir, as principais compreensões de cada uma destas abordagens, assim como a sistematização realizada na forma do grupo Questões. Resumimos, na tabela 19, as principais preocupações possíveis da AC, CTS(A) e Questões, isto é, algumas das principais diferenças que os trabalhos com cada uma dessas abordagens podem ter. 
Tabela 19 - Resumo das principais compreensões possíveis de AC, CTS(A) e Questões

\begin{tabular}{ccc}
\hline Alfabetização Científica & CTS(A) & Questões \\
\hline $\begin{array}{c}\text { AC preocupada com a leitura } \\
\text { e interpretação de textos, } \\
\text { tabelas e gráficos }\end{array}$ & $\begin{array}{c}\text { CTS(A) preocupada em } \\
\text { investigar as influências da } \\
\text { sociedade sobre o } \\
\text { desenvolvimento científico }\end{array}$ & $\begin{array}{c}\text { Questões preocupadas com a } \\
\text { dimensão ambiental, a saúde } \\
\text { pública, a ética e a moral }\end{array}$ \\
$\begin{array}{c}\text { AC preocupada com o fazer } \\
\text { científico, a construção de } \\
\text { experimentos e hipóteses }\end{array}$ & $\begin{array}{c}\text { CTS(A) preocupada com as } \\
\text { consequências sociais e } \\
\text { ambientais dos produtos } \\
\text { tecnológicos }\end{array}$ & $\begin{array}{c}\text { Questões preocupadas com } \\
\text { controvérsias sobre resultados } \\
\text { de pesquisas científicas, } \\
\text { riscos e benefícios e situações } \\
\text { concretas }\end{array}$ \\
\hline $\begin{array}{c}\text { AC preocupada com as } \\
\text { relações CTS(A) e a emissão } \\
\text { de julgamentos }\end{array}$ & $\begin{array}{c}\text { CTS(A) preocupada em } \\
\text { criticar o modelo de Política } \\
\text { Científico-Tecnológica dos } \\
\text { países latino-americanos }\end{array}$ & $\begin{array}{c}\text { Questões preocupadas com o } \\
\text { meio ambiente, sua } \\
\text { conservação e degradação }\end{array}$ \\
\hline
\end{tabular}

Fonte: Bondezan (2019).

A denominação, Alfabetização Científica, possui algumas convergências com outras, tais como Letramento Científico e Enculturação Científica. Esta primeira expressão pode ser usada com o intuito de realizar uma aproximação com a alfabetização proposta por Paulo Freire, isto é, associando a leitura da palavra à leitura de mundo, considerando-a como essencial para a construção de uma consciência crítica.

Especificamente a respeito da segunda expressão, Letramento Científico, temos uma preocupação com o ato de aprender ou ensinar a ler e a escrever, havendo um destaque para a ciência como linguagem e seu uso dentro de um grupo social. Finalmente, a terceira expressão, Enculturação Científica, tem como intenção destacar a ciência como uma cultura e a necessidade de se colocar os alunos em contato com ela.

As diferentes concepções de AC e as expressões que dela se aproximam, podem ser reunidas em três grandes grupos, ainda que haja algumas divergências entre os pesquisadores e suas classificações. O primeiro destes grupos inclui as concepções de AC que valorizam a leitura de textos, tabelas e gráficos. Estas atividades são realizadas com o intuito de incentivar os estudantes a compreender as informações presentes em reportagens jornalísticas e materiais de divulgação científica.

O segundo grupo está associado ao fazer científico, incentivando o seu raciocínio, a elaboração de hipóteses e modelos e a realização de experiências. É importante para este grupo, também, a inclusão de discussões sobre fatores éticos e morais, fatores que deveriam ser os guias das pesquisas científicas. 
Por fim, o terceiro grupo está associado às relações entre ciência, tecnologia, sociedade e ambiente, defendendo que a leitura de gráficos e tabelas, assim como a compreensão de conceitos próprios da ciência e suas grandezas possam proporcionar aos estudantes a emissão de julgamentos sobre, por exemplo, a escolha da matriz energética de um país e as ações tomadas pelo governo e empresas para reduzir os impactos ambientais.

A denominação Ciência, Tecnologia, Sociedade e Ambiente pode aparecer sem a última palavra, evidenciando a existência de duas denominações, CTS e CTSA. Elas, contudo, não são suficientes para compreender a grande quantidade de encaminhamentos possíveis, já que possuem muitas especificidades.

Dentre alguns dos pressupostos e objetivos gerais presentes dentro destas duas denominações, podemos citar a preocupação em promover a tomada de decisões coletivas em questões relacionadas à Ciência e à Tecnologia, o empoderamento individual dos estudantes, o pensamento crítico e a argumentação lógica.

A tomada de decisões coletivas, central para as abordagens CTS(A), por sua vez, não pode ser entendida como uma simples escolha, mas sim como um procedimento que é realizado considerando os conhecimentos adquiridos ao longo das aulas, tanto envolvendo conteúdos das disciplinas de Ciências Naturais, quanto das outras disciplinas que foram eventualmente associadas.

Guia boa parte das abordagens CTS(A), também, uma crítica, em alguma maneira, ao modo de produção capitalista, principalmente no que diz respeito a seus desdobramentos, como o consumo desenfreado de recursos naturais, a obsolescência planejada dos objetos tecnológicos e a busca cega por lucro, que levam a um desrespeito estrutural do meio ambiente. Estas abordagens CTS(A) têm como tarefa, assim, combater estes problemas que assolam a humanidade e o meio ambiente, mesmo que com encaminhamentos diversos.

Apesar de possuírem semelhanças, são várias as diferenças entre as abordagens CTS(A), que podem ser compreendidas de pelos menos duas maneiras distintas:

A primeira delas é a centralidade que assumem as discussões CTS nas abordagens, podendo ser pensada tanto a partir da separação em oito níveis que quantificam a proporção existente entre os “conteúdos puros de ciência” e os “conteúdos CTS”, quanto contabilizando o valor atribuído à ciência, à tecnologia e à sociedade, distinguindo as atividades que continuam a privilegiar a ciência (Cts), as que privilegiam a tecnologia (cTs) e as que privilegiam a sociedade (ctS). 
A segunda maneira de se compreender estas diferenças é através da linha de pensamento adotada. Estas linhas foram desenvolvidas em regiões geográficas específicas do planeta, a saber, Europa, América do Norte e América Latina ao longo da segunda metade do século passado. Esta divisão geográfica, mesmo que em alguma medida superada, pode ser útil na compreensão das preocupações da CTS(A).

A linha europeia ou acadêmica tem sua origem com cientistas, engenheiros, sociólogos e humanistas, e busca investigar a influência da sociedade sobre o desenvolvimento científico.

A linha americana, ou social, por sua vez, surgiu muito ligada aos movimentos sociais, como os grupos pacifistas e ativistas dos direitos humanos, tendo como preocupação as consequências sociais e ambientais dos produtos tecnológicos.

Finalmente, temos o Pensamento Latino Americano em CTS (PLACTS), originado a partir de reflexões críticas sobre o modelo linear de desenvolvimento e com intenção de mudança social para os países latino-americanos. Esta linha se preocupa em não apenas questionar as consequências sociais do desenvolvimento Científico e Tecnológico ou seus antecedentes, mas, principalmente, em criticar o modelo de Política Científico-Tecnológica adotada pelos países latino-americanos, que tem por base os países de primeiro mundo e vai contra suas necessidades regionais.

As Questões Sociocientíficas, as Questões Controversas e as Questões Socioambientais, reunidas dentro do grupo Questões, possuem pressupostos e objetivos semelhantes entre si, ainda que com suas diferenças.

As Questões frequentemente têm como ponto de partida temas presentes no cotidiano dos alunos, dando atenção à dimensão ambiental, à saúde pública, à ética e à moral. Dentre os temas abordados, temos o consumo e a produção de alimentos transgênicos, a realização do aborto, a anorexia, a automedicação, a disposição do lixo e o consumo de drogas por adolescentes.

A ética e a moral são dimensões frequentemente privilegiadas pelas Questões e aparecem durante situações de tomada de decisão que exigem princípios com um caráter de universalidade, como a vida, a consciência, as leis, a autoridade e as punições. A moralidade pode ser pensada de três formas distintas, a saber, como um conjunto de regras e princípios que podem ser usados para solucionar dilemas de forma prévia; como levando-se em consideração as consequências esperadas de determinada decisão ou ação; e como baseada em 
cuidado, rejeitando uma eventual fórmula única e se valendo da emoção, da simpatia e da empatia para a tomada de decisões.

É importante para as Questões, também, o estudo de situações controversas, que podem ser de três tipos: associadas aos resultados das pesquisas científicas, sendo controversa e/ou complexa a determinação de grandezas, como a temperatura média da Terra; associadas ao cálculo dos riscos e benefícios de determinado produto ou processo da tecnologia; e associadas a situações concretas e específicas, em geral presentes nos meios de comunicação, como as catástrofes de Mariana e Brumadinho.

As Questões, finalmente, podem destacar os aspectos ambientais, tanto se voltando de maneira mais ampla para a questão ambiental, seus impactos e reflexos na sociedade; quanto destacando a proposição de ações paliativas que acabam por minimizar a visível e estrutural degradação do meio ambiente e desencorajar ações populares mais enérgicas.

Fica bastante nítida, assim, a grande quantidade de compreensões, pressupostos teóricos e encaminhamentos possíveis em cada uma das denominações recorrentes no ensino de ciência que visam a cidadania.

\subsection{Aproximações entre as abordagens preocupadas com a cidadania}

O cenário bastante complexo com cada uma das denominações podendo seguir vários encaminhamentos pode ser parcialmente compreendido identificando eventuais afinidades existentes entre estas abordagens. De fato, ainda que não se possa realizar nenhuma afirmação categórica, dados os limites da análise realizada, é possível inferir algumas aproximações entre os encaminhamentos seguidos.

Em primeiro lugar, temos a já ressaltada aproximação entre Questões Sociocientíficas, Controversas e Socioambientais, que permitiu a união dessas abordagens dentro do grupo denominado Questões. Esta aproximação também foi verificada de maneira empírica, quando foi observada a existência de um número bastante reduzido de trabalhos que fez menção a apenas uma dessas denominações.

De fato, ao considerar as abordagens reunidas em três grupos ou ênfases, isto é, AC, CTS(A) e Questões, como apresentado pela figura 2 (página 79), há uma sobreposição bastante baixa, com apenas 18\% das pesquisas fazendo menção a mais de uma ênfase. Sobre a 
quantidade de trabalhos em cada um dos grupos, $40 \%$ deles se referiram à CTS(A), $27 \%$ à AC e 15\% às Questões.

Em segundo lugar, há algumas peculiaridades e aproximações nas Naturezas dos Trabalhos, principalmente quando relacionadas com as Ênfases adotadas. Considerando apenas a natureza do total de trabalhos, temos, como mostra a figura 5 (página 82), que 56\% deles se dedicam a realizar Análises, tanto de aulas aplicadas, quanto de materiais didáticos e documentos reguladores, enquanto 18\% deles realizam Levantamento de Concepções, 13\% Revisões Bibliográficas, 10\% Reflexões Teóricas e apenas 3\% Propostas Didáticas.

Ao combinar a Natureza dos Trabalhos com as Ênfases, como apresentado na figura 6 (página 83), é possível perceber algumas tendências, mesmo havendo um domínio das Análises em todas as três abordagens identificadas e mesmo os Levantamentos de Concepções aparecendo em segundo lugar. Considerando as Revisões Bibliográficas, há uma quantidade delas dedicadas à CTS(A) muito maior do que as voltadas às outras duas ênfases. As Reflexões Teóricas, por outro lado, parecem ser mais importantes para as Questões do que para as outras duas abordagens.

Esta configuração, que pode ser relacionada com a frequente menção de alguns trabalhos a mais de uma denominação, nos indica que as abordagens CTS(A) e AC, em alguma medida, estão mais consolidadas, enquanto as Questões estão menos estabelecidas. Se para as primeiras há uma maior necessidade de propor atividades novas, as analisar, levantar as concepções prévias de professores e alunos e revisar a produção bibliográfica, para o último grupo, a maior preocupação está em realizar reflexões teóricas e delinear mais claramente quais os rumos que estão sendo tomados.

Em terceiro lugar, pode-se identificar a relação das Ênfases com as diferentes etapas da escolarização, como retrata a figura 7 (página 85). No Ensino Infantil e Fundamental temos que o número de trabalhos voltados à AC é o dobro dos dedicados à CTS(A), não existindo nenhum representante da ênfase Questões. Para os demais níveis, por outro lado, a CTS(A) possui quantidade maior que o dobro das outras duas ênfases, que aparecem com quantidades relativamente próximas.

Assim, mesmo que existam trabalhos de AC em todos os níveis de escolarização, é possível inferir a existência de uma maior afinidade desta ênfase com os níveis iniciais e, de maneira oposta, a CTS(A) e as Questões se aproximam mais dos níveis avançados da trajetória escolar. 
Em quarto lugar, pode-se relacionar as Ênfases com a Temática dos trabalhos, identificando tendências entre as três abordagens e as disciplinas curriculares de ciências, tanto de maneira isolada, quanto buscando uma interdisciplinaridade. De acordo com a tabela 6 (página 84), considerando todo o recorte de pesquisas voltadas à promoção da cidadania no ensino de ciências, é possível perceber que a disciplina de Física possui pouco menos da metade do número de trabalhos das outras duas disciplinas.

Além disso, 41\% das pesquisas não tem a disciplinaridade como ponto de partida, tanto por se voltarem à disciplina de Ciências do Ensino Infantil e Fundamental, quanto por buscar, de alguma maneira, uma interdisciplinaridade nos outros níveis de escolarização.

A articulação da Temática dos trabalhos com as Ênfases, conforme apontado na figura 9 (página 88), permite a identificação de algumas aproximações, ainda que a quantidade de pesquisas voltadas à CTS(A) seja dominante e as AC apareçam em segundo plano em quase todas as temáticas.

De fato, dentro da temática de Ciências no Ensino Infantil e Fundamental os trabalhos dedicados à AC aparecem com quantidade significativamente maior que os de CTS(A), com as Questões possuindo proporção quase nula. Este resultado, portanto, reforça a aproximação identificada da AC com os níveis iniciais da escolarização.

Dentro das abordagens interdisciplinares, embora também exista um domínio da CTS(A), a quantidade de trabalhos voltados às Questões é quase o dobro dos voltados à AC. Este resultado, também destoante dos demais, indica a potencialidade das Questões para abordagens interdisciplinares.

Em quinto lugar, finalmente, podem ser identificadas algumas tendências das Ênfases com as perspectivas de cidadania que as pesquisas adotam. Ainda que seja muito difícil delimitar precisamente a perspectiva de cidadania de cada um dos trabalhos, é possível considerá-la como pertencente a um dos três Propósitos Educacionais, a saber, Percepções, Questionamentos e Compromisso Social.

O primeiro desses propósitos, o desenvolvimento de Percepções, considera a educação como tendo a função de reconhecer e compreender os problemas em questão, buscando construir uma nova imagem do conhecimento científico, contextualizá-lo e aproximá-lo do cotidiano dos estudantes.

O segundo propósito, o desenvolvimento de Questionamentos, assume a educação como voltada à formação de uma postura crítica e questionadora, uma postura que discuta as 
implicações do desenvolvimento científico-tecnológico e incentive a utilização responsável dos recursos naturais e aparatos tecnológicos.

Por fim, o terceiro propósito, Compromisso Social, considera essencial que a contextualização do conhecimento, a compreensão do mundo, seu questionamento e o posicionamento dos alunos, implique, também, o desenvolvimento de uma cultura de participação.

Se no total da amostra houve um ligeiro destaque dos Questionamentos, como mostra a figura 3 (página 80), com os outros dois propósitos possuindo quantidades bastante próximas, considerando as Ênfases de maneira separada, como representado na figura 4 (página 81), é possível identificar algumas tendências.

Dentro dos trabalhos de AC há um domínio nítido das Percepções, com os outros dois propósitos aparecendo com quantidades consideravelmente menores. Dentro dos trabalhos voltados à CTS(A), por outro lado, predominam os Questionamentos, com os outros dois propósitos aparecendo com quantidades menores mas bastante próximas. Finalmente, embora nas pesquisas da ênfase Questões os Questionamentos sejam dominantes, os Compromissos Sociais aparecem com quantidade próxima e as Percepções, com quantidade muito pequena.

Esta configuração indica a existência de afinidades entre as ênfases e alguns dos Propósitos Educacionais, isto é, com determinadas concepções de cidadania. Para as AC é muito importante reconhecer e compreender situações e problemas da sociedade, sendo o desenvolvimento de posturas questionadoras e de uma cultura de participação algo um tanto secundário.

Para as Questões, por outro lado, a preocupação está em incentivar posturas críticas e uma participação em sociedade que envolva a ciência e a tecnologia. Para as CTS(A), contudo, não é possível afirmar a existência de uma afinidade nítida com um dos propósitos.

\subsection{Aspectos influenciadores das práticas preocupadas com a cidadania}

O cenário bastante complexo de atividades voltadas à promoção da cidadania no ensino de Ciências pode ser compreendido tanto considerando algumas das definições das denominações recorrentes, identificando a afinidade delas com determinados níveis de ensino, perspectivas de cidadania, disciplinas científicas, entre outros, como explicitado 
anteriormente, quanto reconhecendo os principais fatores que influenciam a prática voltada à promoção da cidadania.

A identificação dos principais fatores que influenciam as páticas preocupadas com a cidadania foi realizada a partir da análise das atividades didáticas relatadas por trabalhos diretamente relacionados com a sala de aula. A análise, detalhada anteriormente, se debruçou sobre 16 pesquisas e forneceu fatores que foram reunidos em sete eixos, destacando aspectos como a abordagem do conhecimento científico adotada, a dinâmica das aulas, o grau de engajamento dos alunos e o contexto em que a prática docente está inserida.

O primeiro desses eixos, intitulado “Tema de referência”, quantifica a potencialidade do tema escolhido para a cidadania, potencialidade que seria própria do tema, associada a um recorte mais restrito a conceitos curriculares ou a um recorte mais amplo e envolvendo mais de uma disciplina.

O segundo eixo, "Relação do professor com o conhecimento científico", identifica a origem do conhecimento científico trabalhado em aula, isto é, quais as motivações para seu estudo e quais os agentes educacionais que participam de sua seleção.

O eixo III, intitulado “Engajamento dos alunos”, quantifica o grau de motivação e engajamento dos alunos diante das atividades realizadas, sempre com base nos relatos apresentados.

O quarto eixo, denominado “Atividades desenvolvidas em sala”, se volta para a dinâmica estabelecida na sala de aula, diferenciando, por exemplo, a postura passiva dos alunos em aulas expositivas e seu trabalho em equipe em aulas colaborativas.

O eixo V, "Participação na sociedade que os alunos desenvolvem”, dá atenção para as posturas cidadãs que são incentivadas em sala de aula, incluindo desde posturas bastante individuais e passivas, até posturas mais coletivas e participativas.

O sexto eixo, intitulado "Contexto da prática docente", se volta para a realidade em que a atuação docente está inserida, destacando tanto a influência que o currículo, as avaliações externas e a coordenação exercem nas atividades realizadas, quanto o número de aulas que foi utilizado.

O eixo VII, finalmente, destaca as concepções de cidadania apresentadas pelos autores, mesmo que elas fiquem restritas às discussões teóricas e não se materializem em suas práticas de sala de aula. 
Cada um destes sete eixos possui determinado número de categorias, construídas a partir das análises e com o objetivo de serem de natureza semelhante entre si e de possuírem determinada gradatividade. Em vários dos eixos esta gradatividade pode ser associada com as abordagens visando a cidadania, indo desde ações mais individuais e passivas, até ações de caráter coletivo e propositivo. Em alguns eixos, porém, esta associação com a cidadania não pode ser realizada tão facilmente.

Vale a pena destacar a ausência de juízos de valor na construção das categorias, isto é, não consideramos que determinadas concepções de cidadania ou que algumas das abordagens sejam mais desejáveis ou melhores que outras, já que estão associadas, de fato, a contextos de atuação distintos.

As categorias e os eixos foram criados a partir de uma amostra específica de trabalhos e, apesar de serem por ela influenciados, acreditamos terem potencialidade para uso em contextos mais amplos.

A tabela 20, a seguir, apresenta as categorias do primeiro eixo, assim como o número de trabalhos que foi encaminhado para cada uma delas e sua proporção no total da amostra.

Tabela 20 - Resultados do eixo I, “Tema de Referência”

\begin{tabular}{cccc}
\hline Categoria & \multicolumn{2}{c}{ Quantidade } & Proporção (\%) \\
\hline Tema de referência muito específico & 5 & 31 \\
\hline Tema de referência com pouca potencialidade para a cidadania & 3 & 19 \\
\hline Tema atual e cotidiano com potencialidade para a cidadania & 2 & 12 \\
\hline Tema abrangente e com grande potencialidade para a cidadania & 6 & 37 \\
\hline
\end{tabular}

Fonte: Bondezan (2019).

Foram vários os temas escolhidos pelos autores, tanto localizados, quanto amplos e relacionados a temáticas interdisciplinares. Considerando os temas a partir das categorias identificadas, houve predomínio das pesquisas que tinham temas de referência bastante amplos e com grande potencialidade, num total de $37 \%$.

Apareceram com grande quantidade, também, os trabalhos que possuíam um tema de referência muito específico e um tanto distante da cidadania, num total de 31\%. Ficaram em menor número as pesquisas que se voltavam para um tema com pouca potencialidade (18\%) e aquelas com temas atuais e cotidianos com potencialidade moderada (12\%).

A tabela 21, a seguir, apresenta as categorias do segundo eixo, bem como o número de trabalhos em cada uma delas e sua proporção no total da amostra. 
Tabela 21 - Resultados do eixo II, "Relação do professor com o conhecimento científico"

\begin{tabular}{ccc}
\hline Categoria & Quantidade & Proporção (\%) \\
\hline Conhecimento advindo do conteúdo curricular & 4 & 25 \\
\hline Conhecimento advindo de um tema cotidiano & 9 & 56 \\
\hline Conhecimento advindo de uma temática cidadã & 3 & 19 \\
\hline
\end{tabular}

Fonte: Bondezan (2019).

Na maioria dos trabalhos (56\%) o tema para estudo foi selecionado a partir do cotidiano, evidenciando sua potencialidade para as atividades didáticas, em especial as voltadas à cidadania. Em um quarto das pesquisas esta seleção foi feita a partir do currículo, demonstrando sua importância na decisão do que será estudado.

Por fim, temos que a temática cidadã foi a motivação para o conhecimento estudado em apenas $19 \%$ dos trabalhos, resultado que pode ser explicado ou justificado por quatro suposições:

Em primeiro lugar, existe a possibilidade dos pesquisadores realizarem uma associação bastante direta entre as temáticas cidadãs e as cotidianas, relação que, apesar de talvez não ser tão simples, acabar por desencorajar a motivação por temáticas cidadãs.

Em segundo lugar, existe a possibilidade de ser bastante difícil para os pesquisadores selecionar um tema que de fato seja significativo para os alunos e que esteja intimamente relacionado com a vida em sociedade.

É possível, em terceiro lugar, que as imposições curriculares e disciplinares tenham limitado ou dificultado a seleção de temas mais amplos e que proporcionassem abordagens interdisciplinares.

Há a possibilidade, finalmente, da baixa influência de temáticas cidadãs na definição dos conhecimentos não ser um problema, sendo o incentivo de uma postura cidadã tal qual a pretendida por seus idealizadores de fato colocada em prática.

A tabela 22, a seguir, apresenta as categorias do terceiro eixo, assim como o número de trabalhos que foi encaminhado para cada uma delas. Vale a pena destacar que algumas das pesquisas foram encaminhadas para mais de uma categoria. 
Tabela 22 - Resultados do eixo III, “Engajamento dos alunos”

\begin{tabular}{cc}
\hline Categoria & Quantidade \\
\hline Alunos pouco afetados pelas atividades & 1 \\
\hline Alunos burocraticamente motivados pela abordagem & 4 \\
\hline Alunos parcialmente motivados, sem engajamento profundo & 6 \\
\hline Alunos profundamente motivados & 11 \\
\hline
\end{tabular}

Fonte: Bondezan (2019).

Apesar da aproximação de um mesmo trabalho com mais de uma categoria quando diferentes alunos apresentaram comportamentos bastante distintos e quando não foi possível inferir com precisão o grau de envolvimento deles, é possível identificar algumas tendências.

11 das 16 pesquisas relatam atividades em que os alunos foram profundamente motivados, enquanto os alunos estiveram parcialmente motivados em 6 trabalhos, burocraticamente motivados em 4 e inertes ou pouco afetados em apenas 1 .

Esta distribuição mostra que as atividades foram bem-sucedidas em motivar os alunos e os engajar nas aulas, ainda que não seja possível afirmar, com certeza, se a atividade voltada ao incentivo da cidadania de fato atingiu seus objetivos.

A tabela 23, a seguir, mostra as categorias do quarto eixo, assim como o número de trabalhos que foi encaminhado para cada uma delas. Muitas das pesquisas foram encaminhadas para mais de uma categoria, pois desenvolveram mais de um dos tipos de atividade em sala.

Tabela 23 - Resultados do eixo IV, “Atividades desenvolvidas em sala”

\begin{tabular}{cc}
\hline Categoria & Quantidade \\
\hline Atividades expositivas ou de leitura & 16 \\
\hline Levantamento das concepções iniciais dos alunos e problematizações iniciais & 10 \\
\hline Atividades de discussão em grupos, em aulas dialógicas ou debates & 14 \\
\hline Atividades de elaboração individual & 10 \\
\hline Atividades de elaboração coletiva & 11 \\
\hline
\end{tabular}

Fonte: Bondezan (2019).

Todos os 16 trabalhos analisados realizaram atividades expositivas ou de leitura, enquanto em 14 deles houve momentos de discussão e debates e em 11 ocorreram atividades de elaboração coletiva. Os outros dois tipos de atividades, isto é, levantamento de concepções iniciais e atividades de elaboração individual estiveram presentes em 10 dos 16 trabalhos. 
Estes números nos indicam que uma mesma pesquisa apresentou vários tipos de atividades, com várias delas incluindo 3, 4 ou até mesmo 5 dos tipos identificados. Desta forma, mesmo os tipos de atividades que apareceram com menor frequência, como as de elaboração individual e coletiva, apareceram em mais da metade dos trabalhos.

Além da maior frequência de atividades expositivas, vale a pena destacar a importância das atividades de discussão em aulas dialogadas, em grupos ou em debates, situações que favorecem a contraposição e o intercâmbio de ideias, assim como a argumentação dos alunos.

Finalmente, temos que estas categorias refletem especificamente a amostra de trabalhos analisada, isto é, devido ao fato de nenhuma das pesquisas analisadas fazer referência a livros didáticos ou a atividades investigativas, nenhuma das categorias construídas os contemplam.

A tabela 24, a seguir, mostra as categorias do quinto eixo, assim como o número de trabalhos que foi encaminhado para cada uma delas e sua proporção no total da amostra.

Tabela 24 - Resultados do eixo V, "Participação na sociedade que os alunos desenvolvem”

\begin{tabular}{ccc}
\hline Categoria & Quantidade & $\begin{array}{c}\text { Proporção } \\
\text { (\%) }\end{array}$ \\
\hline $\begin{array}{c}\text { Não diretamente relacionada com a vida em sociedade ou } \\
\text { extremamente limitada }\end{array}$ & 5 & 31 \\
\hline $\begin{array}{c}\text { Relacionada com a vida em sociedade de maneira individual e } \\
\text { limitada }\end{array}$ & 6 & 37 \\
\hline Relacionada com a vida em sociedade de maneira individual e ativa & 1 & 6 \\
\hline Relacionada com a vida em sociedade de maneira coletiva e ativa & 4 & 25 \\
\hline
\end{tabular}
Fonte: Bondezan (2019).

Há, aqui, um predomínio das atividades em que os alunos desempenharam posturas relacionadas com a vida em sociedade de maneira individual e limitada, compreendendo 37\% da amostra. A proporção dos trabalhos que não incentivavam posturas cidadãs ou que o fizeram de maneira extremamente limitada é ligeiramente menor, 31\%.

São um quarto do total as pesquisas em que a cidadania é incentivada de maneira coletiva e ativa, enquanto a cidadania em sua forma individual e ativa é promovida em apenas $6 \%$ da amostra.

Foram vários, portanto, os tipos de participação em sociedade que os alunos realizaram nas 16 pesquisas analisadas. Há a presença, assim, desde posturas mais individuais e menos diretamente relacionadas com a cidadania, até posturas mais ativas e coletivas. Mesmo que a 
proporção entre estas posturas não seja tão distante, é nítido um predomínio das que se aproximam do primeiro grupo.

A tabela 25, a seguir, mostra as categorias do sexto eixo, assim como o número de trabalhos que foi encaminhado para cada uma delas e sua proporção no total da amostra. As categorias deste eixo não são exclusivas, versando tanto sobre a extensão em que a atividade se desenvolveu, quanto sobre a influência curricular vivenciada.

Tabela 25 - Resultados do eixo VI, "Contexto da prática docente”

\begin{tabular}{ccc}
\hline Categoria & Quantidade & Proporção (\%) \\
\hline Ensino formal, várias aulas & 11 & 69 \\
\hline Ensino formal, em poucas aulas & 3 & 19 \\
\hline Ensino não formal & 2 & 12 \\
\hline Maior rigidez curricular & 2 & 12 \\
\hline Menor rigidez curricular & 14 & 87 \\
\hline
\end{tabular}

Fonte: Bondezan (2019).

A respeito da extensão das atividades relatadas, 69\% delas se desenvolveram em mais de 5 aulas, enquanto uma parcela bem menor, 19\%, se estendeu por menos tempo. Os trabalhos que fizeram menção a contextos que não o regular, como o contra turno do ensino regular e os projetos de extensão com duração mais flexível, foram 12\% do total.

Apenas $12 \%$ dos trabalhos fizeram menção a uma influência limitadora do currículo e demais fatores externos, enquanto para a grande maioria deles, 87\%, esta influência não foi mencionada.

Este cenário nos indica que boa parte dos trabalhos relata atividades que se desenvolvem em contextos com maior liberdade de atuação, o que possibilitou a seleção dos conteúdos a serem ensinados de maneira mais livre e a realização de atividades que se estenderam por um grande número de aulas.

Talvez estes resultados sejam um tanto esperados, já que os docentes provavelmente não conseguiriam realizar práticas voltadas à cidadania em contextos com liberdade muito reduzida. Vale a pena destacar, também, a quase ausência de rigidez curricular ou de pressões externas em contextos fora do ensino regular.

A tabela 26, a seguir, mostra as categorias do sétimo e último eixo, assim como o número de trabalhos que foi encaminhado para cada uma delas. Uma mesma pesquisa foi 
associada com mais de uma categoria quando houve menção a mais de uma concepção de cidadania, não sendo nosso objetivo, portanto, destacar a visão que se mostrou dominante.

Buscamos, neste eixo, identificar quais as visões sobre cidadania que as pesquisas apresentaram, especialmente ao longo de suas reflexões teóricas, mas também em outros momentos do texto.

Tabela 26 - Resultados do eixo VII, “Cidadania apresentada pelos autores”

\begin{tabular}{cc}
\hline Categoria & Quantidade \\
\hline Alfabetização Científica, CTS(A) e QSC como motivadoras, associadas ou não \\
à cidadania & 4 \\
\hline $\begin{array}{c}\text { Cidadania incentivada na forma do desenvolvimento de “interpretação de } \\
\text { mundo” e “tomada de consciência”, se aproximando das Percepções }\end{array}$ & 8 \\
\hline $\begin{array}{c}\text { Cidadania como se dedicando à “ética”, a “valores” e promovendo o } \\
\text { "pensamento crítico”, se aproximando dos Questionamentos }\end{array}$ & 12 \\
\hline $\begin{array}{c}\text { Cidadania como “posicionar-se frente” a algo, se aproximando do } \\
\text { Compromisso Social, mas que ainda não foi transformada em ação concreta em } \\
\text { sociedade }\end{array}$ & 5 \\
\hline $\begin{array}{c}\text { Cidadania na forma de “resolução de problemas”, “tomada de decisão”, } \\
\text { “desenvolvimento de atitudes”, “embate responsável”, “exercer direitos”, se } \\
\text { aproximando do Compromisso Social }\end{array}$ & 11 \\
\hline
\end{tabular}

Fonte: Bondezan (2019).

Dentre as várias visões de cidadania apresentadas pelos autores, se destacaram aquelas associadas à ética, aos valores e ao pensamento crítico, presentes em 12 das 16 pesquisas. A cidadania na forma de tomada de decisões, desenvolvimento de atitudes e embate responsável, por sua vez, apareceu em 11 trabalhos.

Em quantidades menores apareceram as concepções ligadas à interpretação de mundo e tomada de consciência (8 pesquisas), posicionar-se frente a situações (5) e a presença das denominações voltadas à cidadania como motivadoras das abordagens, mas não necessariamente associadas com a cidadania (4).

Estas concepções de cidadania apareceram ao descrever as concepções que seus idealizadores possuíam acerca dos objetivos da educação, quais as atitudes e posturas que se pretende desenvolver nos alunos e as formas como eles devem se comportar diante de situações e problemas da sociedade. 


\subsection{Panorama sintético das influências das práticas preocupadas com a cidadania}

Os sete eixos e suas respectivas categorias discutidos anteriormente podem ser combinados para compor um segundo panorama das principais influências e características das propostas voltadas à promoção da cidadania.

Este segundo panorama tem o objetivo de sistematizar e articular as contribuições trazidas ao longo desta pesquisa, assim como possibilitar o estabelecimento de uma relação mais direta com a prática docente. A construção deste segundo panorama é possível devido à proximidade de alguns dos eixos, que se complementam.

O segundo panorama é composto por três blocos, que destacam o conteúdo a ser ensinado; os alunos e o modo como se comportam durante as aulas; e o modo como a cidadania é incentivada em sala. A tabela 27, a seguir, resume o segundo panorama, apresentando as preocupações dos blocos que o compõem e as possibilidades de encaminhamentos.

Tabela 27 - Blocos do segundo panorama

\begin{tabular}{|c|c|c|}
\hline Blocos & Preocupações dos Blocos & Possibilidades de encaminhamentos \\
\hline \multirow{2}{*}{$\begin{array}{l}\text { Primeiro } \\
\text { bloco }\end{array}$} & $\begin{array}{l}\text { Localidade ou abrangência do } \\
\text { tema escolhido }\end{array}$ & $\begin{array}{l}\text { De temas curriculares e distantes da cidadania, } \\
\text { até amplos e com grande potencialidade }\end{array}$ \\
\hline & $\begin{array}{l}\text { Motivação para a escolha dos } \\
\text { conhecimentos científicos }\end{array}$ & $\begin{array}{l}\text { - Currículo } \\
\text { - Cotidiano } \\
\text { - Cidadania }\end{array}$ \\
\hline \multirow[b]{2}{*}{$\begin{array}{l}\text { Segundo } \\
\text { bloco }\end{array}$} & $\begin{array}{l}\text { Grau de engajamento dos alunos } \\
\text { ao longo das aulas realizadas }\end{array}$ & $\begin{array}{l}\text { De engajamento pequeno, quando permanecem } \\
\text { distantes e indiferentes, até alto, quando } \\
\text { participam de maneira engajada e espontânea }\end{array}$ \\
\hline & $\begin{array}{c}\text { Tipos de atividades } \\
\text { desenvolvidas }\end{array}$ & $\begin{array}{l}\text { - Atividades expositivas ou de leitura } \\
\text { - Atividades identificando concepções prévias e } \\
\text { realizando problematizações iniciais } \\
\text { - Atividades de discussão e debates } \\
\text { - Atividades de elaboração individual } \\
\text { - Atividades de elaboração coletiva }\end{array}$ \\
\hline $\begin{array}{l}\text { Terceiro } \\
\text { bloco }\end{array}$ & $\begin{array}{l}\text { Maneira como as atividades } \\
\text { desenvolvidas em sala visam } \\
\text { incentivar a cidadania }\end{array}$ & $\begin{array}{l}\text { - Cidadania distante } \\
\text { - Cidadania individual e limitada } \\
\text { - Cidadania individual e ativa } \\
\text { - Cidadania coletiva e ativa }\end{array}$ \\
\hline
\end{tabular}

Fonte: Bondezan (2019). 
Estes três blocos não consideram nem as especificidades do contexto da prática docente, isto é, a influência do currículo e demais fatores externos e a extensão das atividades desenvolvidas, objetos do eixo VI, nem as concepções de cidadania apresentadas pelos autores, tema do eixo VII.

Estes fatores não ficam de fora porque os consideramos menos importantes ou irrelevantes para as atividades voltadas à promoção da cidadania, mas sim por se relacionarem, de acordo com nossos dados, de maneira menos direta com as práticas em sala de aula que incentivam posturas cidadãs.

Mesmo que a grande maioria dos trabalhos considerados em nossa análise tenha se desenvolvido em muitas aulas, e mesmo que apenas dois deles tenham relatado explicitamente uma influência limitadora de fatores externos como o currículo, foram vários os encaminhamentos para a promoção da cidadania adotados. Nossos dados apontam, assim, para a inexistência de uma relação direta entre a extensão da atividade e as influências externas com a perspectiva de cidadania e os encaminhamentos seguidos.

Algo semelhante aconteceu com as concepções de cidadania apresentadas pelos autores que, de acordo com nossos dados, não influenciam tão diretamente as abordagens realizadas. As concepções de cidadania, por terem sido identificadas a partir da menção de cada trabalho a determinadas expressões, impediu que este eixo possuísse uma relação mais direta com as práticas adotadas em sala.

O primeiro bloco do segundo panorama combina os eixos I e II, isto é, o "Tema de Referência” e a "Relação do professor com o conhecimento científico”. Neste bloco são combinadas a localidade ou abrangência do tema escolhido para estudo e sua potencialidade inicial para a cidadania com a motivação para a escolha dos conhecimentos científicos trabalhados em sala.

Os temas estudados em sala de aula podem ser desde profundamente curriculares e específicos, o que tornaria uma abordagem voltada para a promoção da cidadania algo desafiador, como é o caso do tema “cinemática escalar”, até bastante abrangentes e amplos, com grande potencialidade para abordagens interdisciplinares e facilmente relacionáveis com a cidadania, como “ecologia”.

Além dessas possibilidades, temos também os temas com potencialidade limitada para a cidadania, como "termodinâmica" e os temas advindos do cotidiano e com relação com a cidadania moderadamente próxima, como "biodiesel”. 
Dentre as motivações para estudo dos temas científicos em sala, destacamos o currículo, o cotidiano e a cidadania propriamente dita. Quando o currículo é o principal motivador na seleção do tema, a abordagem colocada em prática se inicia distante da cidadania. Quando a seleção é realizada a partir do cotidiano, seja a partir de matérias jornalísticas, seja a partir de vivências do dia a dia dos alunos ou da comunidade local, a relação com a cidadania se torna bastante próxima.

Finalmente, temos os casos em que a cidadania propriamente dita é a motivadora da abordagem, tanto na forma de situações concretas vivenciadas pela comunidade local ou por uma população mais ampla, quanto na forma de matérias jornalísticas sobre uma situação em que estão nítidos aspectos políticos e da vida em sociedade.

O segundo bloco do segundo panorama associa os eixos III e IV, ou seja, o “Engajamento dos alunos” e as “Atividades desenvolvidas em sala”. São combinados, neste bloco, o grau de engajamento dos alunos ao longo das aulas realizadas com os tipos de atividades desenvolvidas.

O engajamento dos alunos nas atividades realizadas pode ser muito pequeno, quando eles permanecem distantes e indiferentes; pequeno, quando realizam as atividades solicitadas de maneira burocrática; médio, quando se mostram parcialmente motivados; e alto, quando participam de maneira engajada e espontânea.

Sobre as atividades realizadas em sala pelos alunos e as posturas que assumem, temos as atividades expositivas ou de leitura; as atividades que identificam suas concepções prévias e realizam problematizações iniciais; as atividades de discussão e debates; as atividades de elaboração individual; e as de elaboração coletiva.

Um maior engajamento dos alunos nas atividades realizadas tem maior potencialidade para facilitar o aprendizado de conceitos científicos e a preparação para a vida em sociedade. De maneira semelhante, embora menos direta, temos um favorecimento da promoção da cidadania nas atividades em que os alunos assumem posturas colaborativas, participativas e criativas, quando comparadas com as atividades que incentivam posturas passivas.

O terceiro bloco, por fim, inclui o eixo V, "Participação na sociedade que os alunos desenvolvem”. Este bloco, tal como o eixo, destaca a relação que os alunos estabelecem com a cidadania durante as aulas, isto é, como as atividades desenvolvidas em sala visam incentivar a participação em sociedade. As relações estabelecidas pelos alunos com a 
cidadania ao longo das aulas podem ser de quatro maneiras, a saber: distante; individual e limitada; individual e ativa; e coletiva e ativa.

A relação é distante quando as atitudes desempenhadas pelos alunos não têm relação direta com a vida em sociedade e quando esta relação é bastante limitada.

A relação com a cidadania ocorre de maneira individual e limitada, por sua vez, quando os alunos são incentivados a identificar situações de interesse e a questionar os aspectos envolvidos, permanecendo numa dimensão individual e não ativista.

Os alunos podem se relacionar com a vida em sociedade, também, de maneira individual e ativa, ou seja, realizando um ativismo individual, por exemplo, na forma de descarte adequando de materiais e na tomada de ações para que áreas degradadas sejam limpas.

Por fim, temos a relação com a cidadania de maneira coletiva e ativa, que ocorre quando o ativismo é colocado em prática coletiva, seja com os demais estudantes da escola ou da comunidade, seja com movimentos sociais, sempre com o objetivo de realizar atividades propositivas. 


\section{Capítulo 8 - Considerações Finais}

A presente pesquisa teve como motivação as várias compreensões da cidadania, as formas como ela pode ser incentivada em atividades didáticas e quais têm sido as contribuições da Pesquisa em Ensino de Ciências nesta direção. Diante destas motivações mais amplas, esta pesquisa teve como objetivo específico aproximar as reflexões produzidas pelos pesquisadores de Ensino de Ciências de um público mais amplo, como professores da educação básica.

Para que este objetivo fosse atingido, adotamos duas estratégias complementares, uma de caráter teórico, e uma de cunho empírico. De um ponto de vista teórico, buscamos em artigos, livros, teses e dissertações os pressupostos, objetivos e preocupações de algumas das abordagens que visam a promoção da cidadania no Ensino de Ciências, isto é, Alfabetização Científica, Ciência, Tecnologia, Sociedade e Ambiente, Questões Sociocientíficas, Questões Controversas e Questões Socioambientais.

Além dessas reflexões, buscamos, também segundo uma perspectiva teórica, a forma como a cidadania é regulamentada por alguns documentos oficiais, os contextos políticos e sociais em que ela pode ser colocada em prática e algumas concepções sobre a ciência e sua dinâmica, que podem influenciar as práticas voltadas à promoção da cidadania no Ensino de Ciências.

Foi realizada, além desta busca teórica, uma busca de natureza empírica, com o intuito de identificar os encaminhamentos mais frequentes das cinco abordagens, algumas afinidades com contextos e práticas específicas e os principais aspectos influenciadores das práticas em sala de aula.

Para a busca empírica, foram considerados os trabalhos publicados nas três últimas edições do ENPEC que mencionavam pelo menos uma das cinco abordagens de interesse. Esta busca empírica foi realizada na forma de duas análises: uma primeira com preocupação mais quantitativa e uma segunda com ênfase qualitativa.

Na primeira análise foram identificadas as concepções de cidadania dos trabalhos, com base nos Propósitos Educacionais de Strieder (2012); quais das cinco abordagens foram realizadas; quais as disciplinas curriculares trabalhadas; quais os objetivos dos trabalhos; e quais as etapas da escolarização a que as pesquisas se dirigiam. Foram buscadas, também 
nessa análise, afinidades entre estes aspectos, destacando os encaminhamentos mais frequentes.

Na segunda análise, por sua vez, foram levantados os aspectos influenciadores das práticas em sala de aula, reunidos em sete eixos, a saber: os conhecimentos científicos estudados; as motivações para sua escolha; o engajamento dos alunos nas atividades; as ações que eles desenvolveram em sala; a relação que estabelecem com a vida em sociedade; o contexto em que a prática está inserida; e as concepções de cidadania apresentadas pelos autores.

Cada um destes sete eixos conta com determinado número de categorias, construídas a partir da amostra de trabalhos analisados, tendo como objetivo detalhar as informações dos eixos e possuindo uma gradatividade na forma com que incentivam a cidadania.

Os pressupostos teóricos das cinco abordagens, bem como as compreensões dos contextos em que a cidadania pode ser colocada em prática e da ciência e sua dinâmica foram, finalmente, articulados com os resultados das duas análises, a fim de dialogar com os professores em exercício e os auxiliarem em sua prática docente, sempre valorizando sua autonomia e sem desconsiderar seu contexto particular de trabalho.

Mesmo que tenham sido várias as contribuições e os resultados da presente pesquisa, julgamos ser importante tecer, aqui, alguns comentários sobre suas limitações, assim como algumas das inquietações surgidas ao longo do trabalho e algumas das potencialidades para pesquisas futuras.

São pelo menos três as principais fontes de limitação da presente pesquisa, a saber, a quantidade de textos reunidos nas reflexões teóricas, a quantidade de trabalhos utilizados nas etapas de análise e o referencial usado para compreender as perspectivas educacionais.

A primeira limitação está nas definições teóricas de cidadania, natureza da ciência e das cinco abordagens recorrentes no ensino de ciências, isto é, AC, CTS(A), QSC, Questões Controversas e Questões Socioambientais, que poderiam ter sido realizadas com o auxílio de maior número de textos.

Além da maior quantidade de artigos, livros, teses e dissertações, poderia ter sido realizado, também, um breve histórico de cada uma das abordagens e poderiam ser apresentados alguns exemplos de como elas vem sendo colocadas em prática. A Educação Ambiental e as Abordagens Temáticas Freireanas, apenas tangenciadas pela presente pesquisa, poderiam ter recebido tanta importância quanto as cinco abordagens identificadas. 
A segunda limitação desta pesquisa está na quantidade de pesquisas selecionadas para as análises. Ainda que 343 trabalhos seja um número bastante representativo, eles são originários de um recorte em apenas três edições de um mesmo evento. Além disso, a primeira análise realizada se debruçou apenas sobre o resumo, título e palavras-chave, e não sobre sua totalidade. A segunda análise, mesmo que tenha se voltado para a íntegra dos trabalhos, considerou apenas 16 deles, quantidade insuficiente para um tratamento estatístico dos resultados e para identificar tendências e afinidades de maneira mais segura.

A terceira limitação se encontra no instrumento utilizado para compreender as visões de cidadania adotadas pelos trabalhos. Os Propósitos Educacionais, desenvolvidos por Strieder (2012), foram usados, principalmente, ao longo da primeira análise, mas, também, em vários outros momentos da dissertação e, ainda que reconheçamos sua importância e potencialidade, entendemos que também possuam limitações.

Em primeiro lugar, é importante salientar que os Propósitos Educacionais foram criados em um contexto diferente do aqui empregado. Isto é, enquanto originalmente tinham como objetivo identificar abordagens CTS presentes no Ensino de Ciências, foram aqui utilizados com o objetivo de compreender as práticas voltadas à promoção da cidadania no Ensino de Ciências de maneira mais ampla.

Em segundo lugar, temos que os Propósitos Educacionais foram construídos como uma dimensão da matriz de referência, intrinsecamente relacionada com os Parâmetros CTS, a outra dimensão. Utilizar apenas aquela dimensão, tal qual realizado na presente pesquisa, implica, assim, numa limitação nos resultados e conclusões obtidos.

Essas limitações do instrumento teórico, contudo, não aparecem de forma bastante nítida ao longo da primeira análise, que considerou apenas os títulos, resumos e palavraschave dos trabalhos. Os três Propósitos Educacionais, isto é, o desenvolvimento de Percepções, Questionamentos e Compromisso Social, se mostraram suficientes como categorias do aspecto de mesmo nome da primeira análise.

As limitações do instrumento teórico aparecem de maneira mais evidente ao longo da segunda análise, voltada para a totalidade das pesquisas. De fato, as três categorias dos Propósitos Educacionais não foram suficientes para avaliar a "Cidadania Apresentada pelos autores”, tema do eixo VII, sendo necessária, para esta tarefa, a criação de outras duas.

A primeira delas inclui os casos em que a AC, a CTS(A) e as Questões são usadas apenas como forma de motivação de abordagens, sem necessariamente possuírem relação 
com a cidadania. A segunda delas, por sua vez, reúne as concepções de cidadania que incentivam posicionamentos diante de situações, o que as aproximam do Compromisso Social, mas que acabam não se transformando em ações concretas em sociedade.

Além das fontes de limitação da presente pesquisa, foram identificadas, também, algumas inquietações e potencialidades para encaminhamentos futuros, que podem contribuir para um aprofundamento das discussões aqui realizadas. Dentre estas inquietações e potencialidades, destacamos os conceitos de cidadania, criticidade, interdisciplinaridade e as discussões sobre a extensão das atividades e sua possível relação com o incentivo da cidadania.

Embora tenham sido apontadas várias definições e reflexões sobre o conceito de cidadania, é inegável sua complexidade e a necessidade de um maior aprofundamento, em especial quando associado com o contexto educacional e com o ensino de ciências.

Ainda que em nenhum momento a criticidade tenha sido amplamente discutida, certamente há aproximações deste conceito com a cidadania e com o incentivo de posturas em sociedade. Além da necessidade de uma melhor definição deste conceito, temos o questionamento a respeito da existência ou não de concepções mais desejáveis de cidadania.

Em outras palavras, ainda que a prática em sala de aula conte com muitas influências e limitações e não caiba o julgamento de atividades já aplicadas, vale a pena o questionamento a respeito da existência de posicionamentos em relação a desastres ambientais, a desigualdades sociais, assim como outras situações envolvendo a ciência e a tecnologia, mais desejáveis que outros.

O conceito interdisciplinaridade, embora apenas tangenciado na presente pesquisa, é considerado como bastante importante por vários trabalhos das abordagens CTS(A) e QSC. Um maior aprofundamento neste conceito ainda é necessário, contudo, para compreender se a articulação entre quaisquer disciplinas é possível ou se haveria uma maior potencialidade ou afinidade entre as disciplinas científicas.

Um maior aprofundamento é necessário, também, para compreender o processo de seleção de temas, isto é, a forma como o tema pode ser delimitado a partir do cotidiano dos alunos ou do currículo e articulado com a cidadania e com as disciplinas curriculares, científicas ou não.

Precisa de um maior aprofundamento, finalmente, a relação existente entre a extensão das atividades e a abordagem de cidadania realizada. Embora a grande maioria dos trabalhos 
de nossa amostra seja constituída de atividades extensas e muitos tenham sidos os encaminhamentos para a cidadania, o que indica a inexistência de uma relação entre estes pontos, a totalidade da situação pode ser outra.

A esse respeito, temos, dentro da produção acadêmica voltada à promoção da cidadania no Ensino de Ciências, a diferenciação entre abordagens pontuais, mais próximas do ensino tradicional e abordagens que buscam promover a cidadania de maneira mais estrutural.

Dentro do primeiro grupo aparecem as expressões “dourar a pílula”, também denominada de “maquiar currículos” (AULER et al., 2007³3 apud STRIEDER, 2012) e “enxertos CTS” (CEREZO, 1998; PINHEIRO, SILVEIRA e BAZZO, 2009) para designar as atividades que não perturbam a estrutura curricular vigente. Estas atividades se desenvolvem em contextos com menor liberdade de atuação, tanto ao longo de poucas aulas, quanto durante algumas aulas de um bloco maior.

No segundo grupo, por outro lado, aparecem as atividades que se desenvolvem em várias aulas e em contextos com maior liberdade de atuação, promovendo um rompimento estrutural com o currículo vigente, a disciplinaridade e outras possíveis restrições.

Esperamos que a presente pesquisa, apesar de suas limitações, possa ser capaz de contribuir para o ensino de ciências voltado à promoção da cidadania, tanto num âmbito mais prático, auxiliando os professores da educação básica em sua prática em sala de aula, quanto num âmbito mais teórico e acadêmico, aprofundando o debate do ensino voltado para a cidadania.

33 AULER, D. et al. Abordagem Temática: Temas em freire e no Enfoque CTS, VI ENPEC, Florianópolis, 2007. 


\section{Referências Bibliográficas}

AGUIAR-SANTOS, D.; VILCHES, A.; BRITO, L. P., Evolução CTS à CTSA nos Seminários Ibero-americanos, Indagatio Didactica, v. 8, n. 1, p. 1961-1974, Aveiro, 2016.

AINKENHEAD, G., What is STS science teaching? In J. SOLOMON, G. AINKENHEAD, STS education: International Perspectives on Reform. New York: Teachers College Press, p. 47-59, 1994.

AULER, D., Alfabetização científico-tecnológica: um novo “paradigma”?, Ensaio Pesquisa em Educação em Ciências, Belo Horizonte, v. 5, n. 1, p. 68-83, 2003.

AULER, D.; DELIZOICOV, D. Alfabetização científico-tecnológica para quê? Ensaio. Belo Horizonte, v.3, n. 1, p. 122-134, 2001.

AULER, D.; et al. Transporte Particular x Coletivo: Intervenção Curricular pautada por interações entre Ciência-Tecnologia-Sociedade, Enseñanza de las Ciências, Barcelona, n. Extra, p. 1-5, 2005.

BARDIN, L. Análise de conteúdo. São Paulo: Edições 70, 2010.

BARNES, B. et al. Architects. In: BARNES, B., Endgame, Fort Collins: DGC Records, p 2011. 1 CD. Faixa 1.

BONDEZAN, G. V. Propostas com ênfase CTS: Investigando potencialidades para uso em sala de aula. Monografia de fim de curso (não publicada), disciplina Monografia para Licenciatura. Instituto de Física, Universidade de São Paulo, 2016, disponível em: $<$ https://docs.wixstatic.com/ugd/d4f708_6f3cbb869a884e0a9388543ef5cf3f77.pdf>. Acesso em: 04/06/2019.

BONDEZAN, G. V., KAWAMURA, M. R. D. Perspectivas de cidadania e suas manifestações na pesquisa em Ensino de Ciências, XVII EPEF, Campos do Jordão, 2018.

Os percursos da cidadania e suas compreensões: como vêm evoluindo essas questões?, XII ENPEC, Natal, 2019.

BONETTI, M. C., Rádio comunitária nas escolas: Professores reconhecendo o eletromagnetismo numa perspectiva reflexiva voltada à educação do campo, Indagatio Didactica, v. 8, n. 1, p. 500-513, Aveiro, 2016.

BRASIL. Constituição da República Federativo do Brasil, 1988.

. Decreto-lei n ${ }^{\circ}$ 9394, de 20 de dezembro de 1996. Estabelece as diretrizes e bases da educação nacional. Diário Oficial da União, Brasília, 23 de dezembro de 1996. 
. Conselho Nacional de Educação (CNE). Resolução n. 3, de 26 de junho de 1998. Institui as Diretrizes Curriculares Nacionais para o Ensino Médio. Diário Oficial da República Federativa do Brasil, Brasília, DF, 5 ago. 1998a.

. Conselho Nacional de Educação (CNE). Parecer n. 15, de 1 de junho de 1998. Diretrizes Curriculares Nacionais para o Ensino Médio. Brasília, DF, 1998b.

- Parâmetros Curriculares Nacionais para o Ensino Médio, Ministério da Educação. Secretaria de Educação Média e Tecnológica, Brasília, DF, 1999.

- Orientações Educacionais Complementares aos Parâmetros Curriculares Nacionais. Vol. 2. Ministério da Educação. Secretaria de Educação Média e Tecnológica, Brasília, DF, 2002.

- Diretrizes Curriculares Nacionais Gerais da Educação Básica. Brasília, Ministério da Educação. Secretaria de Educação Básica. Secretaria de Educação Continuada, Alfabetização, Diversidade e Inclusão. Secretaria de Educação Profissional e Tecnológica. Conselho Nacional da Educação. Câmara Nacional de Educação Básica, p. 562, 2013.

. Decreto-lei $n^{\circ} 13.005$, de 25 de junho de 2014. Aprova o Plano Nacional de Educação - PNE e dá outras providências. Diário Oficial da União, Brasília, 26 de junho de 2014.

Base Nacional Comum Curricular, Ministério da Educação. Secretaria da Educação Básica, Brasília, DF, 2017a.

Decreto-lei $\mathrm{n}^{0}$ 13.415, de 16 de fevereiro de 2017. Altera as leis 9.394 de 20 de dezembro de 1996 e 11.494 de 20 de junho de 2007. Diário Oficial da União, Brasília, 17 de fevereiro de 2017b.

CACHAPUZ, A. et al., A necessária renovação do Ensino de Ciências, São Paulo: Editora Cortez, 2005.

CARDOSO, Z. Z.; ABREU, R. O.D.; STRIEDER, R. B., Lixo eletrônico como tema CTS: estudo exploratório sobre compreensão dos estudantes, Indagatio Didactica, v. 8, n. 1, p. 1610-1626, Aveiro, 2016.

CARNIO, M. P.; CARVALHO, W. L. P., Contribuições das questões sociocientíficas para se pensar a natureza do conteúdo de ciências: um olhar a partir da filosofia de Theodor Adorno, X ENPEC, Águas de Lindóia, 2015.

CARVALHO, A. M.; MOREIRA, A. F.; AGUIAR Jr, O., Avaliação de estudantes sobre uma sequência de ensino de termodinâmica orientada por uma abordagem CTS, X , Águas de Lindóia, 2015.

CARVALHO, Í. N. et al. Projetos de lei no ensino de ciências: possibilidades para modelagem de questões socio-científicas, X ENPEC, Águas de Lindóia, 2015. 
CASSAB, M. A. Democracia como balizadora do Ensino das Ciências na Escola: Como discutir este desafio?, Revista Brasileira de Pesquisa em Educação em Ciências. Belo Horizonte, v. 8 n. 2, 2008.

CEREZO, J. A. L., Ciencia, Tecnología y Sociedad: el estado de la cuestión en Europa y Estados Unidos, Revista Iberoamericana de Educación. v. 18, p. 41-68, Madrid, 1998.

CUNHA, R. B., Alfabetização científica ou letramento científico?: interesses envolvidos nas interpretações da noção de scientific literacy, Revista Brasileira de Educação, Rio de Janeiro, v. 22, n. 68, 2017.

FERREIRA, N., As pesquisas denominadas de Estado da Arte, Educação e Sociedade, Campinas, v. 79, p. 257-272. 2002. 1987.

KRASILCHIK, M. O Professor e o currículo das ciências. São Paulo: EPU/EDUSP,

LAUGKSCH, R. C. Scientific literacy: a conceptual overview. Science Education, Hoboken, v. 84, n. 1, p. 71-94, 2000.

LIMA, G. F. C. Crise ambiental, educação e cidadania: os desafios da sustentabilidade emancipatória. In: LOUREIRO, C. F. B.; LAYRARGUES, P.; CASTRO, R. S. (Orgs.). Educação ambiental: repensando o espaço da cidadania. São Paulo: Cortez, 2002. p. 109141.

MELO, S. P.; SOUZA, A. S.; CONTENTE, A. C. P., O ensino de Ciências na Educação de Jovens e Adultos: uma abordagem CTS como prática educativa no espaço prisional, $\mathbf{X}$, Águas de Lindóia, 2015.

MOEBUS, R.; MARTINS, I., Leitura e Alfabetização Científica nas Aulas de Ciências: Uma revisão de artigos publicados entre 2008 e 2012, IX ENPEC, Águas de Lindóia, 2013.

MORAES, M.; PEIXOTO, J., Estado do conhecimento como perspectiva crítica para as pesquisas em educação. Revista Reflexão e Ação, Santa Cruz do Sul, v. 25, n. 3, p. 321-338, 2017.

MOROSINI, M. e FERNANDES, C., Estado do Conhecimento: conceitos, finalidades e interlocuções, Educação Por Escrito, Porto Alegre, v. 5, n. 2, p. 154-164, 2014.

PENHA, S. P.; CARVALHO, A. M. P., Como avaliar a qualidade da argumentação dos estudantes em atividades sociocientificas?, XVI EPEF, Natal, 2016.

PÉREZ, L. F. M. Questões Sociocientíficas na prática docente: Ideologia, autonomia e formação de professores, São Paulo: Editora Unesp, 2012.

PÉREZ, L. F. M.; CARVALHO, W. L. P., Contribuições e dificuldades da abordagem de questões sociocientíficas na prática de professores de ciências, Educação e Pesquisa, São Paulo, v. 38, n. 3, p. 727-741, 2012. 
PINHÃO, F. L. O muro transparente: o ensino de ciências e as demandas de formação para a cidadania nos anos iniciais do ensino fundamental. Tese Doutorado Universidade Federal do Rio de Janeiro, Núcleo de Tecnologia Educacional para a Saúde, Rio de Janeiro, 2015.

PINHÃO, F.; MARTINS, I. Cidadania e Ensino de Ciências: Questões para o debate, Ensaio Pesquisa em Educação em Ciências, Belo Horizonte, v.18, n. 3, p.9-29, 2016.

PINHEIRO, N. A. M., SILVEIRA, R. M. C. F. e BAZZO, W. A., O contexto científicotecnológico e social acerca de uma abordagem crítico-reflexiva: perspectiva e enfoque, Revista Iberoamericana de Educación, v. 49, n. 1, p. 1-14, Madrid, 2009.

PIZARRO, M. V.; LOPES Jr, J., Indicadores de Alfabetização Científica: uma revisão bibliográfica sobre as diferentes habilidades que podem ser promovidas no Ensino de Ciências nos anos iniciais, Investigação em Ensino de Ciências, Porto Alegre, v. 20, n. 1, p. 208-238, 2015.

RIBEIRO, R.; KAWAMURA, M. R. D. Educação Ambiental e Temas Controversos, Revista Brasileira de Pesquisa em Educação em Ciências, p. 159-169, v. 14, ${ }^{\circ}$ 2, Belo Horizonte, 2014.

RIBEIRO, T. V.; SANTOS, A. T.; GENOVESE, L. G. R., A história dominante do movimento CTS e o seu papel no Subcampo Brasileiro de Pesquisa em Ensino de Ciências CTS, X ENPEC, Águas de Lindóia, 2015.

ROCHA, D.; DEUSDARA, B. Análise de Conteúdo e Análise do Discurso: aproximações e afastamentos na (re)construção de uma trajetória. Revista Alea Estudos Neolatinos, Universidade Federal do Rio de Janeiro, v.7, n.2, p. 305-322, 2005.

ROMANOWSKI, J. e ENS, R., As pesquisas denominadas do tipo de "Estado da Arte" em Educação, Diálogo Educ., Curitiba, v. 6, n. 19, p. 37-50, 2006.

ROSO, C. C.; AULER, D., A participação na construção do currículo: práticas educativas vinculadas ao movimento CTS, Ciência e Educação, v. 22, n. 2, p. 371-389, Bauru, 2016.

SACHS, I., Brasil e os Riscos da Modernidade. Ciência Hoje: v20, n. 119, p. 12-14, Rio de Janeiro, 1996.

SADLER, T. D.; ZEIDLER, D. L., The Morality of Socioscientific Issues: Construal and Resolution of Genetic Engineering Dilemmas, Science Education, v. 88, n. 1, p. 4-27, 2004.

SANTOS, R. A.; AULER, D., Ampliação da concepção de participação no campo CTS, X, Águas de Lindóia, 2015. 
SANTOS, W. L. P., Educação científica na perspectiva de letramento como prática social: funções, princípios e desafios, Revista Brasileira de Educação, Rio de Janeiro, v. 12 n. 36, p. 474-550, 2007.

SANTOS, W. L. P.; MORTIMER, E. F., Uma análise de pressupostos teóricos da abordagem CTS (Ciência-Tecnologia-Sociedade) no contexto da educação brasileira. Ensaio Pesquisa em Educação em Ciências, Belo Horizonte, v. 2, n. 2, 1-23, 2002.

Abordagem de aspectos sociocientíficos em aulas de ciências: possibilidades e limitações. Investigações em Ensino de Ciências. v. 14, n. 2, p. 191-218, 2009.

SASSERON, L. H., CARVALHO, A. M. P de, Alfabetização científica: uma revisão bibliográfica, Investigações em Ensino de Ciências, Porto Alegre, v.16, n. 1, p.59-77, 2011.

SAVIANI, D. Epistemologia e teorias da educação no Brasil. Pro-posições, Campinas, v. 18, n. 1, p. 15-27, 2007.

SEVERINO, A. J. Metodologia do trabalho científico, São Paulo, Cortez Editora, (24 ${ }^{\mathrm{a} e d}$.), 2017.

STRIEDER, R.B. Abordagem CTS na Educação Científica no Brasil: Sentidos e Perspectivas. Tese de Doutorado - Instituto de Física e Faculdade de Educação, Universidade de São Paulo, São Paulo, 2012.

STRIEDER, R. B.; KAWAMURA, M. R. D. Educação CTS: Parâmetros e Propósitos Brasileiros, Alexandria: R. Educ. Ci. Tec., Florianópolis, v. 10, n. 1, p. 27-56, 2017.

TEIXEIRA, P. M. M. Educação científica sob a perspectiva da Pedagogia HistóricoCrítica e o do movimento C.T.S. no Ensino de Ciências. Ciência \& Educação. Bauru, v. 9, n. 2, p. 177-190, 2003.

TENREIRO-VIEIRA, C.; VIEIRA, R.M., Construção de práticas didático-pedagógicas com orientação CTS: impactos de um programa de formação continuada de professores de ciências do Ensino Básico, Ciência \& Educação, Bauru, v. 11, n. 2, p. 191-211, 2005.

TOTI, F. A.; PIERSON, A. H. C.; SILVA, L. F., Diferentes perspectivas de cidadania presentes nas discussões atuais em defesa da abordagem CTS na educação científica, VII ENPEC, Florianópolis, 2017.

WATANABE-CARAMELLO, G. Aspectos da complexidade: contribuições da Física para a compreensão do tema ambiental, Tese de Doutorado - Instituto de Física e Faculdade de Educação, Universidade de São Paulo, São Paulo, 2012.

ZEIDLER, D.; KEEFER, M. The role of Moral Reasoning and the Status of Socioscientific Issues In Science Sducation: Philosophical, Psychological and Pedagogical Considerations. In: (org.). The Role of Moral Reasoning on Socioscientific Issues and Discourse in Science Education. Kluwer Academic Publishers, Dordrecht, p. 738, 2003. 


\section{Trabalhos analisados}

BATISTA, K. de C. P., ASSIS, A., TRAVAIN, S. A., Efeito fotoelétrico - Uma abordagem experimental para o Ensino de Física Moderna, XI ENPEC, Florianópolis, 2017.

CARDOSO, Z. Z.; et al. Radioatividade e CTS: Resultados de uma implementação, X ENPEC, Águas de Lindóia, 2015.

CARVALHO, A. M.; MOREIRA, A. F.; AGUIAR Jr, O., Avaliação de estudantes sobre uma sequência de ensino de termodinâmica orientada por uma abordagem CTS, X ENPEC, Águas de Lindóia, 2015.

FADINI, G. P., LEITE, S. Q. M., Uma Pedagogia Histórico-Crítica para discutir Educação Alimentar: Aspectos metodológicos num Projeto Escolar de Ensino Médio, XI ENPEC, Florianópolis, 2017.

FREITAS, K. R. et al. Biodiesel como Tema Gerador no Processo de Alfabetização Científica, X ENPEC, Águas de Lindóia, 2015.

MARTINEZ, G. et al. Experimentação problematizadora e as concepções dos alunos sobre a utilização de textos no ensino de Química, XI ENPEC, Florianópolis, 2017.

MARTINS, T. G. G., RIBEIRO, E. E. H., AYRES A. dos S., A Alfabetização Científica a partir da experimentação no ensino de lentes esféricas: possibilidades e limitações, XI ENPEC, Florianópolis, 2017.

MOURA, C. N.; COMARU, M. W. Pedagogia Histórico-Crítica e Arte sequencial: Metodologias alternativas no ensino de ciências, X ENPEC, Águas de Lindóia, 2015.

NUNES, B. R.; LINDEMANN, R. N.; GALIAZZI, M. do C., Abordagem de SituaçãoProblema na sala de aula de química: o ensino CTS contribuindo para a percepção social, $\mathbf{X}$ ENPEC, Águas de Lindóia, 2015.

PEREIRA, J., et al. O estudo da Energia com enfoque CTS, fundamentado no documentário POWER, XI ENPEC, Florianópolis, 2017.

SANTANA, R. C. M., TERRA, V. R., LEITE, S. Q. M., Do caldo de cana ao açúcar: estudo cultural com enfoque CTS/CTSA na educação Química interdisciplinar, XI ENPEC, Florianópolis, 2017.

SANTOS, A. de O. S., et al. Saberes escolares, científicos e populares a partir de um estudo sobre a influência da concentração de metais no crescimento de raízes de batata doce, XI ENPEC, Florianópolis, 2017.

SILVA, J. C. P. A., et al. Abordagem CTSA: Remediação Ambiental como tema problematizador, XI ENPEC, Florianópolis, 2017. 
SOUZA, A. M.; MARTINS, S., Uma proposta de ensino de Física utilizando a elaboração de vídeos experimentos, X ENPEC, Águas de Lindóia, 2015.

TERRA, V. R., LEITE, S. Q. M., Estudos culturais sobre a produção de vinagre para articular saberes escolares, científicos e populares: uma educação química com enfoque CTS/ CTSA, XI ENPEC, Florianópolis, 2017.

VALE, W. K. M; SOUZA, S. R.; FIRME, R. N. Investigando questões sociocientíficas na temática Combustíveis fósseis e alternativos: em quais contextos são discutidas as relações CTS?, X ENPEC, Águas de Lindóia, 2015. 


\section{Anexos}

Tabela 28 - Propósitos Educacionais e Ênfases dos trabalhos da segunda análise

\begin{tabular}{|c|c|c|c|}
\hline Trabalho & Título dos trabalhos & Ênfases & $\begin{array}{l}\text { Propósitos } \\
\text { Educacionais }\end{array}$ \\
\hline $\begin{array}{l}\text { (1) Moura e } \\
\text { Comaru (2015) }\end{array}$ & $\begin{array}{l}\text { Pedagogia Histórico-Crítica e Arte sequencial: } \\
\text { Metodologias alternativas no ensino de ciências }\end{array}$ & $\begin{array}{l}\text { Alfabetização } \\
\text { Científica }\end{array}$ & Percepções \\
\hline $\begin{array}{l}\text { (2) Freitas et al. } \\
\text { (2015) }\end{array}$ & $\begin{array}{c}\text { Biodiesel como Tema Gerador no Processo de } \\
\text { Alfabetização Científica }\end{array}$ & $\begin{array}{l}\text { Alfabetização } \\
\text { Científica }\end{array}$ & Percepções \\
\hline $\begin{array}{l}\text { (3) Vale, Souza } \\
\text { e Firme (2015) }\end{array}$ & $\begin{array}{l}\text { Investigando questões sociocientíficas na temática } \\
\text { Combustíveis fósseis e alternativos: em quais contextos } \\
\text { são discutidas as relações CTS? }\end{array}$ & $\begin{array}{l}\text { CTS(A) e } \\
\text { Questões }\end{array}$ & $\begin{array}{l}\text { Compromisso } \\
\text { Social }\end{array}$ \\
\hline $\begin{array}{l}\text { (4) Souza e } \\
\text { Martins (2015) }\end{array}$ & $\begin{array}{l}\text { Uma proposta de ensino de Física utilizando a elaboração } \\
\text { de vídeos experimentos }\end{array}$ & CTS(A) & Percepções \\
\hline $\begin{array}{l}\text { (5) Nunes, } \\
\text { Lindemann e } \\
\text { Galiazzi (2015) }\end{array}$ & $\begin{array}{l}\text { Abordagem de Situação-Problema na sala de aula de } \\
\text { química: o ensino CTS contribuindo para a percepção } \\
\text { social }\end{array}$ & CTS(A) & Percepções \\
\hline $\begin{array}{l}\text { (6) Carvalho, } \\
\text { Moreira e } \\
\text { Aguiar Jr (2015) }\end{array}$ & $\begin{array}{l}\text { Avaliação de estudantes sobre uma sequência de ensino de } \\
\text { termodinâmica orientada por uma abordagem CTS }\end{array}$ & CTS(A) & $\begin{array}{l}\text { Compromisso } \\
\text { Social }\end{array}$ \\
\hline $\begin{array}{l}\text { (7) Cardoso et } \\
\text { al. (2015) }\end{array}$ & Radioatividade e CTS: Resultados de uma implementação & CTS(A) & $\begin{array}{l}\text { Compromisso } \\
\text { Social }\end{array}$ \\
\hline $\begin{array}{l}\text { (8) Martins, } \\
\text { Ribeiro e Ayres } \\
\text { (2017) }\end{array}$ & $\begin{array}{l}\text { A Alfabetização Científica a partir da experimentação no } \\
\text { ensino de lentes esféricas: possibilidades e limitações }\end{array}$ & $\begin{array}{l}\text { Alfabetização } \\
\text { Científica }\end{array}$ & Percepções \\
\hline $\begin{array}{l}\text { (9) Batista, Assis } \\
\text { e Travain (2017) }\end{array}$ & $\begin{array}{l}\text { Efeito fotoelétrico - Uma abordagem experimental para o } \\
\text { Ensino de Física Moderna }\end{array}$ & CTS(A) & Questionamentos \\
\hline $\begin{array}{l}(10) \text { Terra e } \\
\text { Leite (2017) }\end{array}$ & $\begin{array}{l}\text { Estudos culturais sobre a produção de vinagre para } \\
\text { articular saberes escolares, científicos e populares: uma } \\
\text { educação química com enfoque CTS/CTSA }\end{array}$ & CTS(A) & Percepções \\
\hline $\begin{array}{l}\text { (11) Silva et al. } \\
\text { (2017) }\end{array}$ & $\begin{array}{c}\text { Abordagem CTSA: Remediação Ambiental como tema } \\
\text { problematizador }\end{array}$ & CTS(A) & Questionamentos \\
\hline $\begin{array}{l}\text { (12) Santana, } \\
\text { Terra e Leite } \\
\quad(2017)\end{array}$ & $\begin{array}{l}\text { Do caldo de cana ao açúcar: estudo cultural com enfoque } \\
\text { CTS/CTSA na educação Química interdisciplinar }\end{array}$ & $\begin{array}{l}\text { CTS(A) e } \\
\text { Questões }\end{array}$ & Questionamentos \\
\hline $\begin{array}{l}\text { (13) Pereira et } \\
\text { al. (2017) }\end{array}$ & $\begin{array}{c}\text { O estudo da Energia com enfoque CTS, fundamentado no } \\
\text { documentário POWER }\end{array}$ & CTS(A) & $\begin{array}{l}\text { Compromisso } \\
\text { Social }\end{array}$ \\
\hline $\begin{array}{l}\text { (14) Martinez et } \\
\text { al. (2017) }\end{array}$ & $\begin{array}{l}\text { Experimentação problematizadora e as concepções dos } \\
\text { alunos sobre a utilização de textos no ensino de Química }\end{array}$ & $\begin{array}{l}\text { Alfabetização } \\
\text { Científica e } \\
\text { CTS(A) }\end{array}$ & Questionamentos \\
\hline $\begin{array}{l}\text { (15) Santos et al. } \\
\text { (2017) }\end{array}$ & $\begin{array}{l}\text { Saberes escolares, científicos e populares a partir de um } \\
\text { estudo sobre a influência da concentração de metais no } \\
\text { crescimento de raízes de batata doce }\end{array}$ & Questões & Percepções \\
\hline
\end{tabular}




\begin{tabular}{cccc}
\hline Trabalho & Título dos trabalhos & Ênfases & $\begin{array}{c}\text { Propósitos } \\
\text { Educacionais }\end{array}$ \\
\hline $\begin{array}{c}\text { (16) Fadini e } \\
\text { Leite (2017) }\end{array}$ & $\begin{array}{c}\text { Uma Pedagogia Histórico-Crítica para discutir Educação } \\
\text { Alimentar: Aspectos metodológicos num Projeto Escolar } \\
\text { de Ensino Médio }\end{array}$ & Questões & $\begin{array}{c}\text { Compromisso } \\
\text { Social }\end{array}$ \\
\hline
\end{tabular}

Fonte: Bondezan (2019).

Tabela 29 - Ficha de análise do trabalho Freitas et al. (2015)

\begin{tabular}{|c|c|c|}
\hline $\begin{array}{l}\text { Eixo de } \\
\text { Análise }\end{array}$ & & Informações extraídas e comentários \\
\hline \multirow{2}{*}{$\begin{array}{c}\text { Tema de } \\
\text { Referência }\end{array}$} & $\begin{array}{l}\text { Apresentado } \\
\text { pelos autores }\end{array}$ & Biodiesel \\
\hline & Compreensão & $\begin{array}{l}\text { O tema biodiesel é bastante atual e cotidiano, sendo frequentemente retratado } \\
\text { em noticiários. Contudo, ele não é tão amplo como "combustíveis”, o que o } \\
\text { deixa um pouco mais distante de abordagens mais gerais e interdisciplinares. }\end{array}$ \\
\hline \multirow{2}{*}{$\begin{array}{l}\text { Relação do } \\
\text { professor com } \\
\quad \text { o } \\
\text { conhecimento } \\
\text { científico }\end{array}$} & $\begin{array}{l}\text { Apresentado } \\
\text { pelos autores }\end{array}$ & "incentivá-las a ingressar em carreiras de Ciências Exatas e Tecnológicas” \\
\hline & Compreensão & $\begin{array}{l}\text { Embora a síntese do biodiesel seja um tema que aparece frequentemente na } \\
\text { mídia, sendo, portanto, cotidiano, ele acaba sendo tratado como um pretexto } \\
\text { para as atividades de laboratório, isto é, como sendo curricular. }\end{array}$ \\
\hline \multirow[t]{2}{*}{$\begin{array}{l}\text { Engajamento } \\
\text { dos alunos }\end{array}$} & $\begin{array}{l}\text { Apresentado } \\
\text { pelos autores }\end{array}$ & $\begin{array}{l}\text { “"me ajudou na aprendizagem na matéria de Química no colégio em relação aos } \\
\text { meus colegas, pois durante as aulas era mais fácil de compreender o conteúdo, } \\
\text { em algumas das aulas práticas já conhecíamos alguns dos métodos e os porquês } \\
\text { daquela tal reação ou os nomes dos reagentes que utilizávamos”” “'essas alunas } \\
\text { aprenderam muito mais do que teoria química, mas aspectos que são relevantes } \\
\text { para toda uma vida, como compromisso, companheirismo e gosto pela ciência.” }\end{array}$ \\
\hline & Compreensão & $\begin{array}{l}\text { Mesmo que o tema da síntese do biodiesel seja por si só bastante motivador, } \\
\text { assim como as ações em laboratórios, no decorrer da proposta são destacados } \\
\text { trechos das alunas que apontam para uma motivação restrita ao fazer } \\
\text { experimental, bastante burocrática. }\end{array}$ \\
\hline \multirow[t]{2}{*}{$\begin{array}{l}\text { Atividades } \\
\text { desenvolvidas } \\
\text { em sala }\end{array}$} & $\begin{array}{l}\text { Apresentado } \\
\text { pelos autores }\end{array}$ & $\begin{array}{l}\text { “Adaptação dos momentos pedagógicos” “Na etapa de problematização inicial } \\
\text { foi realizado um questionário/diagnóstico para identificar o conhecimento } \\
\text { prévio das meninas quanto à experimentação em laboratório, questões de } \\
\text { segurança, conceitos de Química associados ao preparo de soluções, produção } \\
\text { de biodiesel e registro de atividades” "as alunas participaram, como ouvintes } \\
\text { nas duas primeiras semanas das aulas práticas dos alunos de Engenharia” as } \\
\text { alunas receberam artigos sobre as práticas laboratoriais a serem realizadas e “o } \\
\text { acompanhamento da leitura com o esclarecimento do processo". Na } \\
\text { organização do conhecimento foi realizado o procedimento experimental e a } \\
\text { leitura de artigos. "No último momento de aplicação do conhecimento, foram } \\
\text { discutidas as questões associadas às dificuldades ocorridas para a produção em } \\
\text { escala laboratorial e industrial, número de repetições de lavação do biodiesel } \\
\text { com água, rendimento das reações, qualidade do biodiesel produzida, produção } \\
\text { de sabão, entre outros aspectos.” }\end{array}$ \\
\hline & Compreensão & $\begin{array}{l}\text { As atividades desempenhadas pelas alunas se restringiram a práticas } \\
\text { laboratoriais, com poucas discussões mais amplas realizadas. Sobre os três } \\
\text { momentos pedagógicos, a problematização inicial foi um questionário para } \\
\text { descobrir os conhecimentos prévios e no terceiro momento ocorreram } \\
\text { discussões sobre a prática experimental. }\end{array}$ \\
\hline
\end{tabular}




\title{
Eixo de
}

Análise

\author{
Informações extraídas e comentários
}

"as alunas foram instigadas a desenvolverem competências e habilidades como: autonomia, comunicação, domínio e responsabilidade” "porém alguns aspectos como tomada de decisão e anotações para posterior análise crítica dos resultados necessitariam mais situações para ocorrer o desenvolvimento dessa Apresentado competência.” Ao final da prática experimental, as alunas foram incentivadas a pelos autores realizar algumas variações nos reagentes da reação. "Esta ação promoveu a discussão sobre a necessidade de realização de um planejamento experimental (não efetuado) para determinar estatisticamente a melhor proporção biodiesel produzido, com gasto mínimo de reagente e menor tempo operacional possível.”

na sociedade que os alunos desenvolvem

Como demonstrado pelos dois primeiros excertos, presentes no resumo do trabalho, todas as atividades realizadas foram capazes de preparar as alunas para as atividades laboratoriais, porém incapazes de proporcionar a tomada de Compreensão decisão. $\mathrm{O}$ último excerto parece ser o mais próximo que a atividade chegou de uma prática cidadã, mas, aparentemente não foi realizada a conexão entre os diferentes processos de síntese do biodiesel e os impactos que possuem na sociedade e no ambiente.

\begin{tabular}{ccc}
\hline $\begin{array}{c}\text { Contexto da } \\
\text { prática } \\
\text { docente }\end{array}$ & $\begin{array}{c}\text { Apresentado } \\
\text { pelos autores }\end{array}$ & $\begin{array}{c}\text { Duas meninas do primeiro ano do Ensino Médio em escola pública, em horário } \\
\text { fora de aula }\end{array}$ \\
\cline { 2 - 3 } & Compreensão & Nada a comentar \\
\hline
\end{tabular}

"no intuito de incentivá-las a ingressar em carreiras de Ciências Exatas e Tecnológicas” "Uma alternativa para” desenvolver a aprendizagem significativa

e a motivação dos alunos "baseado nas teorias construtivistas, seria a

alfabetização científica (AC), que visa formar cidadãos conscientes para exercerem seus direitos na sociedade moderna e requer o domínio de conceitos Cidadania Apresentado científicos e conhecimento sobre a natureza da Ciência, bem como disposição apresentada pelos autores para imersão em problemas científicos” “a Alfabetização Científica e Técnica pelos autores

(ACT) como uma estratégia pedagógica e epistemológica para abordagem interdisciplinar do ensino de Ciências por meio de projetos, explicitando a necessidade de um contexto, próximo à realidade do aluno, que possibilite desenvolver autonomia, aquisição de competência de comunicação, domínio e responsabilidade."

Compreensão Nada a comentar

Fonte: Bondezan (2019).

Tabela 30 - Ficha de análise do trabalho Vale, Souza e Firme (2015)

\begin{tabular}{ccc} 
Eixo de & & Informações extraídas e comentários \\
Análise & Apresentado & Combustíveis fósseis e alternativos \\
Tema de & pelos autores \\
\cline { 2 - 3 } Referência & Compreensão & $\begin{array}{r}\text { O tema abordado é bastante abrangente e tem grande potencialidade para a } \\
\text { cidadania e para abordagens envolvendo a interdisciplinaridade }\end{array}$ \\
\hline
\end{tabular}




\begin{tabular}{|c|c|c|}
\hline $\begin{array}{l}\text { Eixo de } \\
\text { Análise }\end{array}$ & & Informações extraídas e comentários \\
\hline \multirow{2}{*}{$\begin{array}{l}\text { Relação do } \\
\text { professor com } \\
\text { o } \\
\text { conhecimento } \\
\text { científico }\end{array}$} & $\begin{array}{l}\text { Apresentado } \\
\text { pelos autores }\end{array}$ & $\begin{array}{l}\text { “No ensino de Química, por exemplo, a contextualização dos conteúdos } \\
\text { químicos pode ser feita com a inserção de questões sociocientíficas (QSC), } \\
\text { entendidas como questões ambientais, políticas, econômicas, éticas, sociais e } \\
\text { culturais relativas à ciência e à tecnologia”, que buscam “‘encorajar os alunos a } \\
\text { relacionar suas experiências escolares em ciências com problemas de seu } \\
\text { cotidiano e desenvolver responsabilidades social’” “a temática Combustíveis } \\
\text { fósseis e alternativos parece ser bem promissora para inserção em sala de aula } \\
\text { de questões sociocientíficas” }\end{array}$ \\
\hline & Compreensão & $\begin{array}{c}\text { Segundo a fundamentação teórica do trabalho, a cidadania é central para a } \\
\text { abordagem, com os conteúdos científicos sendo necessários para a discussão } \\
\text { dos combustíveis fósseis. Do ponto de vista prático não fica claro se a cidadania } \\
\text { é mais importante que o cotidiano, inclusive porque a atividade relatada não é a } \\
\text { primeira a ser realizada. }\end{array}$ \\
\hline \multirow{2}{*}{$\begin{array}{c}\text { Engajamento } \\
\text { dos alunos }\end{array}$} & $\begin{array}{l}\text { Apresentado } \\
\text { pelos autores }\end{array}$ & $\begin{array}{l}\text { “Um aspecto observado foi o fato das questões científicas terem sido pouco } \\
\text { ressaltadas pelos alunos.” “não identificamos nos painéis comparativos relações } \\
\text { desses aspectos com os conceitos químicos neles envolvidos. Contudo, era } \\
\text { esperado que os alunos estabelecessem relações entre conceitos químicos e a } \\
\text { temática dos combustíveis fósseis e alternativos, dado que o professor já havia } \\
\text { ministrado o conteúdo de termoquímica abordando conceitos químicos de } \\
\text { energia de ativação, entalpia de reações etc., com os mesmos.” }\end{array}$ \\
\hline & Compreensão & $\begin{array}{l}\text { Não há nenhum trecho do trabalho que especifique as reações que os alunos } \\
\text { tiveram ao longo da proposta. Foram mencionados, apenas, os conteúdos } \\
\text { levantados por eles ao longo do debate. Contudo, devido ao fato dos alunos não } \\
\text { estabelecerem conexões entre os conteúdos químicos anteriormente estudados e } \\
\text { a temática dos combustíveis fósseis, talvez eles não estivessem tão engajados } \\
\text { com a atividade, mas sim motivados burocraticamente. }\end{array}$ \\
\hline \multirow[t]{2}{*}{$\begin{array}{c}\text { Atividades } \\
\text { desenvolvidas } \\
\text { em sala }\end{array}$} & $\begin{array}{l}\text { Apresentado } \\
\text { pelos autores }\end{array}$ & $\begin{array}{l}\text { “Os procedimentos metodológicos envolveram: uma intervenção didática com } \\
\text { atividades de leitura, debate, elaboração e análise de painéis comparativos” } \\
\text { Foram desenvolvidos “questionamentos iniciais sobre a temática, leitura de } \\
\text { texto, debate, e elaboração dos painéis comparativos pelos alunos.” } \\
\text { “O debate intitulado ‘Quem é melhor? Combustível fóssil ou alternativo?’ teve } \\
\text { início com a leitura do texto ‘Biodiesel, possibilidades e desafios’”, com os } \\
\text { alunos sendo divididos em um grupo que apoia os combustíveis fósseis e um } \\
\text { grupo que apoia os combustíveis alternativos. }\end{array}$ \\
\hline & Compreensão & $\begin{array}{l}\text { Infelizmente as autoras não fornecem grandes detalhes da prática realizada em } \\
\text { sala, estando nestes excertos tudo o que foi fornecido. Contudo, visto que a } \\
\text { atividade durou apenas duas aulas, talvez não sejam muitos os detalhes } \\
\text { omitidos. }\end{array}$ \\
\hline $\begin{array}{c}\text { Participação } \\
\text { na sociedade } \\
\text { que os alunos } \\
\text { desenvolvem }\end{array}$ & $\begin{array}{l}\text { Apresentado } \\
\text { pelos autores }\end{array}$ & $\begin{array}{l}\text { “Um aspecto observado foi o fato das questões científicas terem sido pouco } \\
\text { ressaltadas pelos alunos. (...) não identificamos nos painéis comparativos } \\
\text { relações desses aspectos com os conceitos químicos neles envolvidos. Contudo, } \\
\text { era esperado que os alunos estabelecessem relações entre conceitos químicos e } \\
\text { a temática dos combustíveis fósseis e alternativos, dado que o professor já } \\
\text { havia ministrado o conteúdo de termoquímica abordando conceitos químicos de } \\
\text { energia de ativação, entalpia de reações etc., com os mesmos.” }\end{array}$ \\
\hline
\end{tabular}




\begin{tabular}{|c|c|c|}
\hline $\begin{array}{l}\text { Eixo de } \\
\text { Análise }\end{array}$ & & Informações extraídas e comentários \\
\hline & Compreensão & $\begin{array}{l}\text { Os conteúdos abordados nos painéis comparativos sobre a QSC Política e } \\
\text { econômica, como a "Viabilidade política” e a “Alteração de impostos incentivo } \\
\text { de produção” foram apontados por menos de } 30 \% \text { dos painéis. A nosso ver, } \\
\text { estas dimensões são aquelas que mais se aproximam de uma compreensão } \\
\text { global e estrutural, distante das compreensões puramente individuais. Um } \\
\text { contra-argumento é o excerto “Portanto, podemos dizer que as questões } \\
\text { sociocientíficas mais abordadas pelos alunos sobre a temática Combustíveis } \\
\text { fósseis e alternativos foram as de dimensão ambiental e atitudinal relativa aos } \\
\text { valores e atitudes. Este resultado parece sinalizar uma compreensão por parte } \\
\text { dos alunos de relações de causa e efeito entre conservação /degradação do meio } \\
\text { ambiente e as ações e atitudes humanas. Este aspecto é evidenciado quando os } \\
\text { alunos mencionam os efeitos dos combustíveis fósseis e dos combustíveis } \\
\text { alternativos para a sociedade atual e para as gerações futuras, seus agravos na } \\
\text { natureza e indicam a adoção de medidas individuais e coletivas que colaborem } \\
\text { o uso consciente desses produtos.” As próprias autoras apontam, também, que } \\
\text { os alunos não realizaram uma conexão entre a atividade desenvolvida e os } \\
\text { conteúdos científicos estudados nas aulas anteriores. }\end{array}$ \\
\hline \multirow{2}{*}{$\begin{array}{c}\text { Contexto da } \\
\text { prática } \\
\text { docente }\end{array}$} & $\begin{array}{l}\text { Apresentado } \\
\text { pelos autores }\end{array}$ & $\begin{array}{c}\text { Segunda série do Ensino Médio, Camaragipe Pernambuco. } 26 \text { alunos. Duas } \\
\text { aulas de Química }\end{array}$ \\
\hline & Compreensão & Nada a comentar \\
\hline \multirow[t]{2}{*}{$\begin{array}{c}\text { Cidadania } \\
\text { apresentada } \\
\text { pelos autores }\end{array}$} & $\begin{array}{l}\text { Apresentado } \\
\text { pelos autores }\end{array}$ & $\begin{array}{l}\text { “o processo de obtenção e de utilização de combustíveis fósseis produzidos } \\
\text { com recursos não renováveis gerando reações químicas de grande potencial } \\
\text { energético, e diferentes possibilidades de utilização de combustíveis } \\
\text { alternativos produzidos com recursos renováveis para as quais precisam ser } \\
\text { consideradas vantagens ambientais e suas relações com a viabilidade política, } \\
\text { econômica, tecnológica e sociocultural, etc. Além disso, a busca por fontes } \\
\text { alternativas de energia é de grande importância para a sociedade.” “Os } \\
\text { resultados indicam que as questões sociocientíficas enfatizadas pelos alunos } \\
\text { foram as ambientais e atitudinais. Questões tecnológicas, econômicas, políticas, } \\
\text { sociais e científicas tiveram menor ênfase nas discussões. Contudo, elas } \\
\text { precisam ser discutidas em sala de aula quando se trabalha segundo a } \\
\text { abordagem CTS, ou seja, quando se pretende fazer compreender as relações } \\
\text { CTS visando desenvolvimento de atitudes e valores para a tomada de decisão } \\
\text { em situações que envolvam ciência e tecnologia. Assim, aspectos ambientais e } \\
\text { atitudinais abordados isoladamente não darão conta da busca de soluções para } \\
\text { os problemas da sociedade relacionados com ciência e tecnologia.” “Tomando } \\
\text { por base o objetivo de desenvolver nos alunos atitudes e valores para a tomada } \\
\text { de decisão diante de situações envolvam a ciência e a tecnologia” }\end{array}$ \\
\hline & Compreensão & $\begin{array}{l}\text { No primeiro excerto aparece a expressão “viabilidade política, econômica, } \\
\text { tecnológica e sociocultural”, com vários destes termos aparecendo reunidos e } \\
\text { de maneira recorrente ao longo do texto. É razoável afirmar, portanto, que para } \\
\text { as autoras a cidadania estaria intimamente relacionada a essa interface. As } \\
\text { autoras em diversas passagens se usam de pressupostos das QSC e da CTS, mas } \\
\text { não foi possível encontrar uma definição de cidadania mais estritamente } \\
\text { demarcada, a exceção, talvez, do último excerto. O segundo excerto, originário } \\
\text { do resumo do trabalho, indica que, ao final da atividade, os alunos não } \\
\text { adquiriram uma compreensão de cidadania desejada. }\end{array}$ \\
\hline
\end{tabular}

Fonte: Bondezan (2019). 
Tabela 31 - Ficha de análise do trabalho Souza e Martins (2015)

\begin{tabular}{|c|c|c|}
\hline $\begin{array}{l}\text { Eixo de } \\
\text { Análise }\end{array}$ & & Informações extraídas e comentários \\
\hline \multirow[b]{2}{*}{$\begin{array}{l}\text { Tema de } \\
\text { Referência }\end{array}$} & $\begin{array}{l}\text { Apresentado } \\
\text { pelos autores }\end{array}$ & Cinemática Escalar \\
\hline & Compreensão & $\begin{array}{c}\text { O tema “movimentos” seria um tema que, embora bastante distante da } \\
\text { cidadania em si, é bastante amplo e torna abordagens mais abrangentes algo } \\
\text { possível. O tema “cinemática escalar”, contudo, além de pouca potencialidade } \\
\text { para a cidadania, é muito restrito e localizado. }\end{array}$ \\
\hline \multirow{2}{*}{$\begin{array}{l}\text { Relação do } \\
\text { professor com } \\
\text { o } \\
\text { conhecimento } \\
\text { científico }\end{array}$} & $\begin{array}{l}\text { Apresentado } \\
\text { pelos autores }\end{array}$ & $\begin{array}{l}\text { “No enfoque CTS podemos ensinar uma ciência mais aproximada da realidade } \\
\text { do estudante buscando para isso elementos que fazem parte do cotidiano dos } \\
\text { mesmos e dentro desta visão que este trabalho foi desenvolvido" "Na primeira } \\
\text { etapa, de apresentação do conteúdo, foram utilizadas três aulas de cinquenta } \\
\text { minutos, onde os conceitos de velocidade escalar média e aceleração escalar } \\
\text { média foram apresentados pelo professor, em aula expositiva, com o auxilio da } \\
\text { plataforma PHET” }\end{array}$ \\
\hline & Compreensão & $\begin{array}{l}\text { Com os autores compreendendo que o enfoque CTS está associado com o uso } \\
\text { de tecnologias em sala de aula, assim como experiências e um diálogo íntimo } \\
\text { com o cotidiano dos alunos, está bastante claro que o conhecimento científico é } \\
\text { tratado do ponto de vista do cotidiano. }\end{array}$ \\
\hline \multirow[t]{2}{*}{$\begin{array}{l}\text { Engajamento } \\
\text { dos alunos }\end{array}$} & $\begin{array}{l}\text { Apresentado } \\
\text { pelos autores }\end{array}$ & $\begin{array}{l}\text { “ao serem questionados com relação aos gráficos gerados pelo programa não } \\
\text { sabiam relacionar aos conceitos estudados e pesquisados ao longo do trabalho.” } \\
\text { "Um dos grupos mencionados além do vídeo experimento confeccionaram um } \\
\text { dispositivo com materiais alternativos que representaram como forma para o } \\
\text { cálculo da velocidade escalar média apresentando uma associação com a } \\
\text { Robótica livre que realmente surpreendeu a todos os avaliadores inclusive os } \\
\text { próprios colegas de sala.” “Outro aspecto demonstrado por alguns estudante foi } \\
\text { uma total confusão sobre como e quando a realizações da atividade proposta, } \\
\text { ressaltando que estes estudantes não apresentaram o envolvimento necessário } \\
\text { para a realização da atividade” }\end{array}$ \\
\hline & Compreensão & $\begin{array}{c}\text { Foi possível perceber um nível de engajamento dos alunos bastante diverso, isto } \\
\text { é, tivemos tanto alunos pouco afetados pela abordagem, que mostraram não } \\
\text { entender muito bem o que era pedido, quanto alunos que surpreenderam tanto } \\
\text { os colegas quanto os pesquisadores indo muito além do que foi pedido e do que } \\
\text { era esperado. }\end{array}$ \\
\hline $\begin{array}{c}\text { Atividades } \\
\text { desenvolvidas } \\
\text { em sala }\end{array}$ & $\begin{array}{l}\text { Apresentado } \\
\text { pelos autores }\end{array}$ & $\begin{array}{l}\text { “A sequência (...) foi dividida em três etapas: apresentação do conteúdo (3 } \\
\text { aulas), atividades práticas e discussões (6 aulas) e avaliação final (6 aulas).” } \\
\text { “Na proposta didática, o professor apresentou o conteúdo, com uma aula } \\
\text { expositiva, com o auxílio de simulações, disponíveis na plataforma PHET. } \\
\text { Depois disso os estudantes foram estimulados a explorar o conteúdo, } \\
\text { elaborando um projeto em grupo, que consistiu na escolha e construção de um } \\
\text { experimento e da elaboração de um vídeo. Ao final, os trabalhos foram } \\
\text { apresentados e discutidos.” Foi exigido dos grupos a escrita de um “mini } \\
\text { relatório que contasse com todo o procedimento adotado por eles na execução e } \\
\text { finalização dos trabalhos.” Nas apresentações dos alunos foram encontrados } \\
\text { erros conceituais e “ao serem questionados com relação aos gráficos gerados } \\
\text { pelo programa (Tracker) não sabiam relacionar aos conceitos estudados e } \\
\text { pesquisados ao longo do trabalho.” }\end{array}$ \\
\hline
\end{tabular}


Eixo de Análise
Informações extraídas e comentários

Foi dada uma atenção muito grande no uso da tecnologia em sala de aula e na experimentação como formas de motivar os alunos a estudarem e aprenderem os conteúdos propostos. Além do sucesso atingido nessa direção, foram Compreensão incentivadas, também, posturas mais ativas dos alunos na confecção e apresentação de vídeos de experimentos. Temos, ainda, o fato de que alguns alunos não tinham muita noção do que significava o experimento realizado e as medidas coletadas.

\begin{tabular}{ccc}
\hline & $\begin{array}{c}\text { Apresentado } \\
\text { pelos autores }\end{array}$ & Já apresentado nos outros excertos \\
\cline { 2 - 3 } $\begin{array}{c}\text { Participação } \\
\text { na sociedade } \\
\text { que os alunos } \\
\text { desenvolvem }\end{array}$ & Compreensão & $\begin{array}{c}\text { A atividade se voltou com mais atenção ao uso de tecnologia e da } \\
\text { experimentação em sala de aula, incentivando um protagonismo dos estudantes, } \\
\text { com confecção de vídeos de experimentos e a apresentação de seminários. A } \\
\text { cidadania propriamente dita, contudo, pareceu um tanto distante das práticas } \\
\text { realizadas em sala. }\end{array}$ \\
\hline $\begin{array}{c}\text { Contexto da } \\
\text { prática } \\
\text { docente }\end{array}$ & $\begin{array}{c}\text { Apresentado } \\
\text { pelos autores }\end{array}$ & $\begin{array}{c}\text { Escola pública de Uberlândia, quinze aulas. Oito turmas, com } 45 \text { alunos cada } \\
\text { de Primeiro Ano de Ensino Médio }\end{array}$ \\
\cline { 2 - 4 } & Compreensão & Nada a comentar \\
\hline
\end{tabular}

"Sabemos que as novas tecnologias fazem parte do dia a dia da sociedade moderna e que não são muito diferente no ambiente escolar, hoje os estudantes convivem a todo instante com esta evolução tecnológica que os coloca diante das tecnologias digitais." "Percebemos que o avanço das tecnologias digitais proporcionam aos estudantes experiências que o ambiente escolar tradicional não proporciona, geralmente as salas de aulas nas escolas são monótonas, desmotivadoras e entediantes, levando os estudantes a usarem os recursos digitais presentes em seus celulares (...) como ferramenta de passa tempo” "Nesta perspectiva apresentaremos uma proposta de ensino de física onde que faremos o uso de uma abordagem pautada CTS (Ciência, Tecnologia e

Apresentado

Cidadania pelos autores apresentada pelos autores
Sociedade) que se faz presente e que venha a proporcionar um ambiente mais interativo e dinâmico.”

"Mas se aliarmos a prática experimental num enfoque mais CTS poderemos provocar um despertar nesses estudantes pois o ensino estaria mais próximo da sua realidade tornando a aprendizagem mais dinâmica e ativa. Podemos encontrar vários artigos dentro da literatura que comprovem este fato. Assim de acordo com (...): 'Os conhecimentos acerca da ciência numa perspectiva CTS que sejam eticamente orientados, contribuem para a construção de uma cidadania cultural, critica e ativa."”

Para os autores, a CTS é uma abordagem que se usa de recursos tecnológicos Compreensão que já estão no cotidiano dos alunos, assim como recursos experimentais para motivá-los.

Fonte: Bondezan (2019).

Tabela 32 - Ficha de análise do trabalho Nunes, Lindemann e Galiazzi (2015)

\begin{tabular}{|c|c|c|}
\hline $\begin{array}{l}\text { Eixo de } \\
\text { Análise }\end{array}$ & & Informações extraídas e comentários \\
\hline \multirow{2}{*}{$\begin{array}{l}\text { Tema de } \\
\text { Referência }\end{array}$} & $\begin{array}{l}\text { Apresentado } \\
\text { pelos autores }\end{array}$ & Lixo \\
\hline & Compreensão & $\begin{array}{c}\text { O tema "lixo" é bastante abrangente e possui grande potencialidade para } \\
\text { práticas voltadas à cidadania. }\end{array}$ \\
\hline
\end{tabular}




\begin{tabular}{|c|c|c|}
\hline $\begin{array}{l}\text { Eixo de } \\
\text { Análise }\end{array}$ & & Informações extraídas e comentários \\
\hline \multirow[t]{2}{*}{$\begin{array}{l}\text { Relação do } \\
\text { professor com } \\
\quad \text { o } \\
\text { conhecimento } \\
\text { científico }\end{array}$} & $\begin{array}{l}\text { Apresentado } \\
\text { pelos autores }\end{array}$ & $\begin{array}{l}\text { “O projeto começou com uma palestra na escola sobre a temática de resíduos } \\
\text { sólidos com um representante da Secretaria do Meio Ambiente da cidade de } \\
\text { Bagé-RS. Nesta palestra o Representante discutiu sobre o conceito sobre } \\
\text { resíduos sólidos, os impactos no ambiente, o trabalho da prefeitura com relação } \\
\text { ao lixo, assim como outros aspectos no qual procuraram sensibilizar os alunos } \\
\text { ao consumo consciente dos materiais. Todas as abordagens foram discutidas a } \\
\text { partir do contexto real da cidade.” }\end{array}$ \\
\hline & Compreensão & $\begin{array}{l}\text { A problemática do lixo é tratada como relacionada ao meio ambiente e a } \\
\text { sociedade, a ser solucionada pelo governo e pela população geral. }\end{array}$ \\
\hline \multirow[b]{2}{*}{$\begin{array}{l}\text { Engajamento } \\
\text { dos alunos }\end{array}$} & $\begin{array}{l}\text { Apresentado } \\
\text { pelos autores }\end{array}$ & $\begin{array}{l}\text { “A partir disso, foi possível estabelecer que através dos questionários pré e pós- } \\
\text { visita ao aterro foi possível considerar que houve uma certa mudança de } \\
\text { percepção dos alunos quanto a visão do ‘outro’ em sociedade.” }\end{array}$ \\
\hline & Compreensão & $\begin{array}{l}\text { Embora em nenhum momento são explicitados aspectos sobre a motivação dos } \\
\text { estudantes em relação a abordagem, há dados sobre a percepção que eles } \\
\text { possuíam a respeito do aterro sanitário antes e depois da visita. Esses dados } \\
\text { mostram que houve algum nível de mudança de concepção e de sensibilização } \\
\text { dos alunos, que destacaram as “más condições de trabalho dos funcionários” no } \\
\text { aterro e a "naturalidade dos funcionários em meio ao lixo”. }\end{array}$ \\
\hline \multirow[t]{2}{*}{$\begin{array}{l}\text { Atividades } \\
\text { desenvolvidas } \\
\text { em sala }\end{array}$} & $\begin{array}{l}\text { Apresentado } \\
\text { pelos autores }\end{array}$ & $\begin{array}{l}\text { Foram seis as atividades realizadas, incluindo uma palestra sobre resíduos } \\
\text { sólidos, com todas as abordagens sendo discutidas a partir do contexto real da } \\
\text { cidade e com os alunos elaborando “uma escrita reflexiva sobre o que a } \\
\text { atividade lhes fez pensar”; construção de cartilhas sobre o lixo caseiro e } \\
\text { discussão dos dados em roda de conversa; aulas expositivas e construção de } \\
\text { composteira; visitação do aterro sanitário, com comparação entre as visões dos } \\
\text { alunos antes e depois da visita; “elaboração de um projeto de ação a partir da } \\
\text { situação-problema apresentada com o objetivo de contribuir na transformação } \\
\text { dos resíduos gerados com viabilidade econômica e ambiental considerando } \\
\text { aspectos químicos, com os alunos sendo divididos em setores da sociedade; e } \\
\text { apresentação do projeto de ação. }\end{array}$ \\
\hline & Compreensão & $\begin{array}{c}\text { Foram várias e variadas as atividades desenvolvidas pelos alunos. A primeira } \\
\text { atividade talvez tenha sido a mais próxima dos conteúdos curriculares, tendo } \\
\text { como foco os "resíduos sólidos, os impactos no ambiente, o trabalho da } \\
\text { prefeitura com relação ao lixo" }\end{array}$ \\
\hline \multirow{2}{*}{$\begin{array}{l}\text { Participação } \\
\text { na sociedade } \\
\text { que os alunos } \\
\text { desenvolvem }\end{array}$} & $\begin{array}{l}\text { Apresentado } \\
\text { pelos autores }\end{array}$ & $\begin{array}{l}\text { “A palestra além de proporcionar a alguns alunos o avanço na capacidade de } \\
\text { questionar e de levantar hipóteses, também demonstrou-se eficiente quanto a } \\
\text { abordagem da temática na percepção social.” }\end{array}$ \\
\hline & Compreensão & $\begin{array}{l}\text { Durante as diversas atividades os alunos desempenharam diferentes tarefas que } \\
\text { se relacionam de maneiras distintas com sua ação em sociedade. Tanto na } \\
\text { construção das cartilhas sobre o lixo, quanto na elaboração do projeto de ação e } \\
\text { sua apresentação, os alunos assumiram papel bastante ativo e engajado, } \\
\text { bastante próximos da cidadania almejada pelos autores. }\end{array}$ \\
\hline \multirow{2}{*}{$\begin{array}{l}\text { Contexto da } \\
\text { prática } \\
\text { docente }\end{array}$} & $\begin{array}{l}\text { Apresentado } \\
\text { pelos autores }\end{array}$ & $\begin{array}{l}\text { “a presente pesquisa busca contribuir com o ensino de química, no ensino } \\
\text { médio, com o desenvolvimento durante o Estágio Supervisionado IV do curso } \\
\text { de Licenciatura em Química da UNIPAMPA (Bagé-RS)” }\end{array}$ \\
\hline & Compreensão & $\begin{array}{l}\text { Embora a prática em sala foi descrita com grande riqueza de detalhes, não foi } \\
\text { explicitado o número de aulas usadas. Pelo número de atividades, porém, o } \\
\text { número mínimo de aulas gastas deve ter sido superior a dez. }\end{array}$ \\
\hline
\end{tabular}




\begin{tabular}{|c|c|c|}
\hline $\begin{array}{l}\text { Eixo de } \\
\text { Análise }\end{array}$ & & Informações extraídas e comentários \\
\hline \multirow[t]{2}{*}{$\begin{array}{c}\text { Cidadania } \\
\text { apresentada } \\
\text { pelos autores }\end{array}$} & $\begin{array}{l}\text { Apresentado } \\
\text { pelos autores }\end{array}$ & $\begin{array}{l}\text { “Partindo desta premissa (dificuldades de aprendizagem dos estudantes possível } \\
\text { de ser superada com ‘abordagem química por meio de temas relevantes’), surge } \\
\text { o enfoque ambiental de resíduos sólidos que necessita ser discutido em sala de } \\
\text { aula com o objetivo de contribuir para o desenvolvimento de um pensamento } \\
\text { crítico no que se refere às questões sociais, econômicas e tecnológicas } \\
\text { vinculadas a esta temática. No ensino de química, busca-se com o tema lixo } \\
\text { desafiar os alunos a refletirem e participarem ativamente no processo } \\
\text { democrático de tomada de decisões.” “compreende-se que explorar a temática } \\
\text { lixo aliado aos conceitos químicos e a elementos do cotidiano, pode contribuir } \\
\text { no desenvolvimento de cidadania e participação.” Processo educativo que } \\
\text { “envolva o aluno ativamente, o desafie e o coloque em desequilíbrio para } \\
\text { buscar soluções e tomar suas decisões frente a situações problemáticas reais.” } \\
\text { "o currículo de ciências do ensino médio pode configurar-se como caminho } \\
\text { para preparar o indivíduo a participar democraticamente na sociedade na busca } \\
\text { de tomada de decisão para solução de problemas que envolvam aspectos } \\
\text { sociais, tecnológicos, econômicos e políticos.” }\end{array}$ \\
\hline & Compreensão & $\begin{array}{l}\text { A cidadania é definida de maneira bastante rica pelos autores, havendo uma } \\
\text { ampla defesa de uma inserção crítica e ativa dos alunos em sociedade, } \\
\text { principalmente no que diz respeito à tomada de decisão. No que diz respeito à } \\
\text { prática em sala de aula os alunos são incentivados a assumirem papéis de } \\
\text { setores da sociedade e propor ações capazes de solucionar a problemática do } \\
\text { descarte de lixo. Em vários momentos aparece a disposição dos alunos de } \\
\text { agirem em sociedade de maneira individual, ou coletiva e organizada sem } \\
\text { rompimento com estruturas pré estabelecidas. O excerto a seguir justifica esta } \\
\text { compreensão: “O setor governamental permeou a dimensão social quando se } \\
\text { referiu ao lixo como problema de toda sociedade, pois sua geração se dá nos } \\
\text { domicílios, nas ruas, e, isto, reflete ainda mais a necessidade de conscientização } \\
\text { quanto ao consumo consciente e a reciclagem para a construção das lixeiras, } \\
\text { bem como a prática de jogar os resíduos em local apropriado.” }\end{array}$ \\
\hline
\end{tabular}

Fonte: Bondezan (2019).

Tabela 33 - Ficha de análise do trabalho Carvalho, Moreira e Aguiar Jr (2015)

\begin{tabular}{ccc}
\hline $\begin{array}{c}\text { Eixo de } \\
\text { Análise }\end{array}$ & Informações extraídas e comentários \\
\hline & $\begin{array}{c}\text { Apresentado } \\
\text { pelos autores }\end{array}$ & Termodinâmica \\
\cline { 2 - 3 } $\begin{array}{c}\text { Tema de } \\
\text { Referência }\end{array}$ & Compreensão & $\begin{array}{c}\text { O tema de referência é bastante científico, bastante localizado e com relação } \\
\text { não os autores não consigam fazer este tema dialogar com o cotidiano e a } \\
\text { cidadania. }\end{array}$ \\
\hline
\end{tabular}




\begin{tabular}{|c|c|c|}
\hline $\begin{array}{l}\text { Eixo de } \\
\text { Análise }\end{array}$ & & Informações extraídas e comentários \\
\hline \multirow[t]{2}{*}{$\begin{array}{c}\text { Relação do } \\
\text { professor com } \\
\text { o } \\
\text { conhecimento } \\
\text { científico }\end{array}$} & $\begin{array}{l}\text { Apresentado } \\
\text { pelos autores }\end{array}$ & $\begin{array}{l}\text { “(a sequência) Foi iniciada com uma problematização inicial, baseada em Auler } \\
\text { (2005), que pretendia avaliar os conhecimentos prévios dos alunos sobre o } \\
\text { funcionamento do motor de combustão e dos processos de conversão de energia } \\
\text { envolvidos em seu funcionamento, além de criar um contexto para estudo da } \\
\text { Termodinâmica. } \\
\text { A sequência foi elaborada tendo como objeto o motor de combustão interna. O } \\
\text { início da sequência focalizando um objeto da tecnologia tem dois objetivos. Um } \\
\text { deles é o de criar um contexto de significação dos conceitos, modelos, leis e } \\
\text { teorias que seriam estudados no desenvolvimento da sequência. O outro é o de } \\
\text { possibilitar a introdução de uma discussão sobre implicações sociais de } \\
\text { determinada tecnologia, após terem sido discutidos seus fundamentos } \\
\text { científicos.” }\end{array}$ \\
\hline & Compre & $\begin{array}{l}\text { A proposta caminha em direção à cidadania e à promoção de uma “cultura de } \\
\text { participação”, mas tem como ponto de partida o motor a combustão, } \\
\text { equipamento que estaria presente no cotidiano dos alunos. Além disso, seria o } \\
\text { motor o equipamento capaz de contextualizar o estudo dos conhecimentos } \\
\text { científicos e possibilitar as discussões sobre as “implicações sociais de } \\
\text { determinada tecnologia”. }\end{array}$ \\
\hline \multirow[t]{2}{*}{$\begin{array}{c}\text { Engajamento } \\
\text { dos alunos }\end{array}$} & $\begin{array}{l}\text { Apresentado } \\
\text { pelos autores }\end{array}$ & $\begin{array}{c}\text { “Usar a discussão sobre a estrutura e funcionamento do motor de combustão } \\
\text { interna como contexto inicial para o estudo da termodinâmica me motivou para } \\
\text { esse estudo.” } \\
\text { “Após a problematização inicial, o desenvolvimento da sequência, tendo o livro } \\
\text { didático como o principal recurso cria uma descontinuidade, que não explora } \\
\text { todas as possibilidades da tecnologia do motor de combustão, em termos do } \\
\text { desenvolvimento conceitual. A nosso ver, tal fato refletiu negativamente na } \\
\text { motivação dos estudantes e nas relações que efetivamente foram capazes de } \\
\text { estabelecer entre a tecnologia, seus usos e os conceitos da termodinâmica.” } \\
\text { “Os resultados sustentam a decisão pela continuidade da experiência, porém } \\
\text { com um investimento maior na produção de um material alternativo ao livro } \\
\text { didático que dê suporte aos desdobramentos apontados na atividade de } \\
\text { problematização.” }\end{array}$ \\
\hline & Compreensão & $\begin{array}{l}\text { O primeiro excerto é uma das perguntas realizadas pelos autores aos alunos } \\
\text { para avaliar a proposta aplicada. Ela, assim como todas as outras, teve } \\
\text { resultados positivos que apontam para o potencial da abordagem. Além disso, } \\
\text { os autores afirmam que o engajamento dos alunos diminuiu num segundo } \\
\text { momento, quando o estudo se deu com base no livro didático. A real motivação } \\
\text { dos alunos ao longo da atividade não é detalhada. }\end{array}$ \\
\hline $\begin{array}{c}\text { Atividades } \\
\text { desenvolvidas } \\
\text { em sala }\end{array}$ & $\begin{array}{l}\text { Apresentado } \\
\text { pelos autores }\end{array}$ & $\begin{array}{l}\text { A sequência foi (...) iniciada com uma problematização inicial, baseada em } \\
\text { Auler et al. (2005), que pretendia avaliar os conhecimentos prévios dos alunos } \\
\text { sobre o funcionamento do motor de combustão e dos processos de conversão de } \\
\text { energia envolvidos em seu funcionamento, além de criar um contexto para } \\
\text { estudo da Termodinâmica.” “O segundo momento busca ampliar os objetivos } \\
\text { de formação, possibilitando aos alunos a elaboração uma visão crítica das } \\
\text { relações entre ciência, tecnologia e sociedade (...) (e) a Segunda Lei da } \\
\text { Termodinâmica constituiu um contexto para discutir criticamente tecnologias } \\
\text { baseadas na geração de energia térmica.” “Nessa retomada da problematização } \\
\text { inicial (terceiro momento), no contexto do ensino da Segunda Lei da } \\
\text { Termodinâmica, os alunos foram solicitados a produzir um vídeo abordando o } \\
\text { tema ‘Degradação da energia e mobilidade urbana”” }\end{array}$ \\
\hline
\end{tabular}




\begin{tabular}{|c|c|c|}
\hline $\begin{array}{l}\text { Eixo de } \\
\text { Análise }\end{array}$ & & Informações extraídas e comentários \\
\hline & Compreensão & $\begin{array}{l}\text { A atividade, que segue os três momentos pedagógicos, inclui atividades } \\
\text { expositivas que se dedicam a aprofundar os conhecimentos científicos e } \\
\text { curriculares. Além disso, fazem parte das aulas momentos que incentivam os } \\
\text { alunos a produzir um vídeo, o que é uma oportunidade bastante rica para } \\
\text { mobilizar os conhecimentos adquiridos e caminhar na direção de um ativismo. } \\
\text { Não são apresentados, contudo, resultados da produção dos alunos. }\end{array}$ \\
\hline \multirow{2}{*}{$\begin{array}{l}\text { Participação } \\
\text { na sociedade } \\
\text { que os alunos } \\
\text { desenvolvem }\end{array}$} & $\begin{array}{l}\text { Apresentado } \\
\text { pelos autores }\end{array}$ & $\begin{array}{l}\text { “Após a problematização inicial, o desenvolvimento da sequência, tendo o livro } \\
\text { didático como o principal recurso cria uma descontinuidade, que não explora } \\
\text { todas as possibilidades da tecnologia do motor de combustão, em termos do } \\
\text { desenvolvimento conceitual. A nosso ver, tal fato refletiu negativamente na } \\
\text { motivação dos estudantes e nas relações que efetivamente foram capazes de } \\
\text { estabelecer entre a tecnologia, seus usos e os conceitos da termodinâmica.” }\end{array}$ \\
\hline & Compreensão & $\begin{array}{c}\text { A prática em sociedade, embora seja incentivada em todos os momentos da } \\
\text { abordagem, é de maneira mais ativa na confecção de vídeos, que não foi } \\
\text { detalhada. Mesmo assim, a mobilização de conhecimentos científicos para } \\
\text { abarcar a situação em questão é essencial para a prática cidadã e bastante } \\
\text { incentivada. Os próprios autores apontam, porém, que o livro didático, tido } \\
\text { como principal recurso mesmo após as mudanças metodológicas, se configurou } \\
\text { como uma limitação como fonte de informação para solucionar a problemática } \\
\text { do transporte nas grandes cidades. }\end{array}$ \\
\hline \multirow{2}{*}{$\begin{array}{c}\text { Contexto da } \\
\text { prática } \\
\text { docente }\end{array}$} & $\begin{array}{l}\text { Apresentado } \\
\text { pelos autores }\end{array}$ & Escola técnica federal, sete turmas de Ensino Médio, num total de 186 alunos \\
\hline & Compreensão & Não foi especificado o número de aulas em que a atividade foi desenvolvida. \\
\hline \multirow[t]{2}{*}{$\begin{array}{c}\text { Cidadania } \\
\text { apresentada } \\
\text { pelos autores }\end{array}$} & $\begin{array}{l}\text { Apresentado } \\
\text { pelos autores }\end{array}$ & $\begin{array}{c}\text { “o movimento CTS tem colaborado para que a educação cientifica se consolide } \\
\text { no propósito de formação como exercício de cidadania” "tomada de decisão na } \\
\text { sociedade cientifica e tecnológica e o desenvolvimento de valores” “o } \\
\text { movimento CTS no ensino de ciências contribuiu para a inserção de temas } \\
\text { sociocientíficos, a promoção do engajamento em ações sociais responsáveis, a } \\
\text { discussão de questões controversas e de problemas ambientais } \\
\text { contemporâneos” }\end{array}$ \\
\hline & Compreensão & Nada a comentar \\
\hline
\end{tabular}

Tabela 34 - Ficha de análise do trabalho Cardoso et al. (2015)

\begin{tabular}{ccc}
\hline $\begin{array}{c}\text { Eixo de } \\
\text { Análise }\end{array}$ & Informações extraídas e comentários \\
\hline & $\begin{array}{c}\text { Apresentado } \\
\text { pelos autores }\end{array}$ & Radioatividade \\
\cline { 2 - 3 } $\begin{array}{c}\text { Tema de } \\
\text { Referência }\end{array}$ & Compreensão & $\begin{array}{c}\text { O tema Radioatividade, apesar de bastante curricular, é amplo e está } \\
\text { frequentemente presente no cotidiano na forma de noticiários e até mesmo na } \\
\text { escolha da matriz energética de um país, se aproximando da cidadania. }\end{array}$ \\
\hline
\end{tabular}




\begin{tabular}{|c|c|c|}
\hline $\begin{array}{l}\text { Eixo de } \\
\text { Análise }\end{array}$ & & Informações extraídas e comentários \\
\hline \multirow[t]{2}{*}{$\begin{array}{c}\text { Relação do } \\
\text { professor com } \\
\text { o } \\
\text { conhecimento } \\
\text { científico }\end{array}$} & $\begin{array}{l}\text { Apresentado } \\
\text { pelos autores }\end{array}$ & $\begin{array}{l}\text { “a proposta pedagógica sobre Radioatividade foi organizada de forma a } \\
\text { contemplar: } 1 \text {. O desenvolvimento do conteúdo sobre Radioatividade no } \\
\text { formato de aulas expositivas e vídeos. Dentre os assuntos acerca do conteúdo } \\
\text { abordados em sala estão a descoberta/histórico da radioatividade; os efeitos das } \\
\text { emissões radioativas; a natureza das radiações e suas leis; cinética das } \\
\text { desintegrações radioativas; reações artificiais de transmutação; fissão e fusão } \\
\text { nuclear; aplicações das reações nucleares e acidentes nucleares.” } \\
\text { “no caso aqui apresentado, as aulas estiveram centradas na abordagem do } \\
\text { conhecimento científico, da forma como está presente no livro didático adotado } \\
\text { pela escola, sem questionamentos associados ao desenvolvimento científico- } \\
\text { tecnológico e suas implicações/relações com a sociedade. Certamente, essa } \\
\text { abordagem influenciou as produções dos alunos, em especial os textos } \\
\text { elaborados ao final das atividades, que estiveram centrados no conhecimento } \\
\text { científico.” }\end{array}$ \\
\hline & Compreensão & $\begin{array}{l}\text { Embora a atividade tenha contemplado dimensões muito mais amplas, seu } \\
\text { ponto de partida e fio condutor foi o currículo tradicional, fortemente } \\
\text { estabelecido na escola. }\end{array}$ \\
\hline
\end{tabular}

“pôde-se observar, também, que os alunos se mostraram criativos na produção artística. Alguns grupos montaram cenários, utilizaram roupas diferentes, Apresentado fizeram uso de imagens projetadas, montaram vídeos, tocaram instrumentos. Engajamento pelos autores Além disso, se preocuparam em rimar a letra da música, e em escrever os dos alunos roteiros das peças. A escolha da apresentação dos trabalhos, por meio da música e do teatro, teve como intenção dinamizar as apresentações e a pesquisa.”

Compreensão Este excerto permite afirmar que os alunos reagiram muito bem à atividade, ficando profundamente motivados.

Aulas “expositivas e vídeos. Dentre os assuntos acerca do conteúdo abordados em sala estão a descoberta/histórico da radioatividade; os efeitos das emissões radioativas; a natureza das radiações e suas leis; cinética das desintegrações radioativas; reações artificiais de transmutação; fissão e fusão nuclear; aplicações das reações nucleares e acidentes nucleares. Dentre os vídeos Apresentado debatidos em sala estão: ‘Projeto Manhattan - construção da bomba' e ‘Césio pelos autores 137 - Linha Direta’.” Elaboração de música/paródia ou teatro em grupos a respeito de determinados subtemas, bem como apresentação, com recursos audiovisuais à disposição, ocorrida em duas aulas. “elaboração de um texto dissertativo em grupo acerca das impressões percebidas pelo conteúdo estudado, após as aulas e apresentações (...) (podendo) conter aspectos

Atividades desenvolvidas em sala positivos e negativos, impressões pessoais e questionamentos sobre o assunto”

Os alunos desempenham vários tipos de atividades, tanto diretamente ligadas aos conhecimentos científicos, quanto de cunho mais autoral e opinativo, mas sempre possuindo relação com os conteúdos curriculares. A elaboração de

Compreensão paródias, músicas e teatros se mostrou como uma ferramenta promissora, não apenas para motivar os estudantes, mas também para incentivar a articulação dos conhecimentos apreendidos. 
Eixo de Análise

\section{Informações extraídas e comentários}

"A análise do trabalho evidencia que o que prevalece nas produções dos alunos é o conhecimento científico (vocabulário e exemplos), certamente por influência da própria proposta e, também, do contexto escolar. Nesse sentido, destaca-se a importância de inserirmos, também em nossas aulas discussões relacionadas às perspectivas mais criticas de racionalidade científica, a exemplo das limitações da ciência; às implicações do desenvolvimentos tecnológico e à Apresentado importância da participação social. Ou seja, no caso aqui apresentado, as aulas pelos autores estiveram centradas na abordagem do conhecimento científico, da forma como

Participação na sociedade que os alunos desenvolvem está presente no livro didático adotado pela escola, sem questionamentos associados ao desenvolvimento científico-tecnológico e suas implicações/relações com a sociedade. Certamente, essa abordagem influenciou as produções dos alunos, em especial os textos elaborados ao final das atividades, que estiveram centrados no conhecimento científico."

Na atividade desenvolvida os estudantes foram incentivados a desempenhar tanto posturas passivas nas aulas expositivas, quanto posturas mais ativas nas produções autorais. Contudo, essas posturas mais ativas, mesmo possibilitando

Compreensão um maior protagonismo e uma ação em sociedade, segundo os próprios autores, acabaram ficando muito restritas aos conteúdos curriculares, tal qual as aulas expositivas, não sendo observadas manifestações mais críticas nas produções dos alunos.

Segundo ano de Ensino Médio em escola pública federal em Brasília. "Em relação ao ensino de Química nessa escola, percebem-se algumas dificuldades, como o excesso de conteúdo; a ênfase no 'formulismo matemático'; Apresentado dificuldades por parte dos alunos em compreender alguns fenômenos e pelos autores correlacioná-los ao cotidiano; pequeno número de aulas práticas” "a escola mantém um currículo extenso, com diversos tópicos, padronizado para todas as escolas da rede federal a que está submetida" A proposta foi aplicada em 14 aulas a 9 turmas e a 204 alunos.

prática docente

A atividade foi desenvolvida em um contexto usual e notadamente marcado pelo currículo pouco flexível. Este fato não impossibilitou uma atividade Compreensão voltada à cidadania, mas dificultou a discussão de aspectos mais críticos. Esta atividade se desenvolveu em 14 aulas, havendo tempo suficiente para cada uma de suas etapas.

"o ensino de Química deve contribuir para que o aluno tenha condições para interpretar o mundo, questionar, analisar, se inserir de forma crítica nos fatos e acontecimentos com os quais se encontra." "o ensino de ciências deve favorecer

Cidadania apresentada pelos autores
Apresentado pelos autores o conjunto de relações entre o conhecimento científico, o tecnológico e suas implicações sociais, com o objetivo que o aluno estabeleça uma noção que lhe possibilite refletir criticamente sobre a Ciência, a Tecnologia e suas consequências, de forma a se posicionar frente aos problemas sociais.”

Compreensão Nada a comentar

Fonte: Bondezan (2019).

Tabela 35 - Ficha de análise do trabalho Martins, Ribeiro e Ayres (2017)

Eixo de

Análise

Informações extraídas e comentários

Tema de

Referência

Apresentado

pelos autores

Lentes esféricas 


\begin{tabular}{|c|c|c|}
\hline $\begin{array}{l}\text { Eixo de } \\
\text { Análise }\end{array}$ & & Informações extraídas e comentários \\
\hline \multirow{3}{*}{$\begin{array}{l}\text { Relação do } \\
\text { professor com } \\
\quad \text { o } \\
\text { conhecimento } \\
\text { científico }\end{array}$} & Compreensão & $\begin{array}{l}\text { O tema escolhido pelos autores é bastante localizado e curricular, ficando um } \\
\text { tanto distante de abordagens mais amplas e voltadas à cidadania. }\end{array}$ \\
\hline & $\begin{array}{l}\text { Apresentado } \\
\text { pelos autores }\end{array}$ & $\begin{array}{c}\text { “A escolha da turma de segundo ano do ensino médio como público alvo } \\
\text { justifica-se pelo assunto de Óptica fazer parte do conteúdo programático desta } \\
\text { série.” }\end{array}$ \\
\hline & Compreensão & $\begin{array}{c}\text { Tanto pelo tema de referência ser lentes esféricas, portanto, bastante localizado, } \\
\text { quanto pelo fato da turma ter sido escolhida por estar estudando ótica, conteúdo } \\
\text { programático da série, é possível afirmar que a influência do currículo é } \\
\text { bastante grande. }\end{array}$ \\
\hline \multirow[t]{2}{*}{$\begin{array}{c}\text { Engajamento } \\
\text { dos alunos }\end{array}$} & $\begin{array}{l}\text { Apresentado } \\
\text { pelos autores }\end{array}$ & $\begin{array}{l}\text { “a maioria dos estudantes conseguiu relacionar os termos pouco elaborados } \\
\text { utilizados para responder ao Questionário 1, aos termos físicos propostos nas } \\
\text { aulas empregados na resolução do Questionário } 2 \text { - como ‘convergente’, } \\
\text { ‘divergente’, ‘espessa’, ‘curvatura’ e ‘foco’ - de forma correta, coerente às } \\
\text { definições aceitas pela comunidade científica.” “A utilização da oficina } \\
\text { experimental como ferramenta pedagógica se mostrou eficiente por possibilitar } \\
\text { que os estudantes interagissem com os conceitos durante a aula, testando as } \\
\text { possibilidades, a fim de melhorar seus resultados, manipular os materiais, } \\
\text { observando a mudança da imagem projetada ou visualizada no caso das lentes, } \\
\text { estimulou a criatividade dos estudantes e os motivou a aprender, a questionar e } \\
\text { a se interessar pelos conceitos científicos presentes no simples fato de ver.” }\end{array}$ \\
\hline & Compreensão & $\begin{array}{c}\text { Não é possível afirmar com certeza quanto os alunos foram tocados e } \\
\text { motivados pela abordagem. Contudo, aparentemente, eles aprenderam bastante } \\
\text { com a atividade e foram capazes de responder as perguntas propostas e } \\
\text { construir o experimento pedido. Assim, os alunos estão pelo menos } \\
\text { burocraticamente motivados pela abordagem. }\end{array}$ \\
\hline
\end{tabular}

Realização de uma oficina experimental "dividida em três momentos pedagógicos”. Na problematização inicial, foi apresentado à turma um binóculo que após ser utilizado por todos os alunos, foi desmontado. A partir disso, foi Apresentado discutido o motivo de ocorrerem os fenômenos de ampliação e diminuição das

Atividades desenvolvidas pelos autores em sala imagens. Na organização do conhecimento foram estudadas sistematicamente

as características das lentes e das imagens formadas. Na aplicação do conhecimento foi proposto a realização em grupo de um projetor caseiro.

Compreensão

As atividades realizadas parecem ter dado conta de ensinar alguns conceitos de ótica aos estudantes com uso de práticas em sala variadas.

“A atividade proposta consistiu na realização de uma oficina experimental,

Participação na sociedade que os alunos desenvolvem

Apresentado pelos autores elaborada com o objetivo de servir como ferramenta para a observação, coleta de dados e análise do processo de construção do conhecimento e alfabetização cientificamente dos estudantes.”

Compreensão A proposta como um todo deu bastante atenção à elaboração de experimentos, investigativos ou não.

"estudantes do segundo ano do ensino médio de uma escola da rede estadual de $\begin{array}{lrl}\text { Apresentado } & \text { ensino situada no Distrito de Mosqueiro/PA" “A oficina experimental foi } \\ \text { pelos autores } & \text { aplicada em sala de aula com duração de duas horas” A turma era composta por }\end{array}$

Contexto da prática docente 12 alunos.

A atividade foi realizada em duas aulas em ensino regular e com aparente Compreensão ausência de rigidez curricular, mesmo que os autores tenham seguido o currículo. 


\begin{tabular}{|c|c|c|}
\hline $\begin{array}{l}\text { Eixo de } \\
\text { Análise }\end{array}$ & & Informações extraídas e comentários \\
\hline \multirow[t]{2}{*}{$\begin{array}{c}\text { Cidadania } \\
\text { apresentada } \\
\text { pelos autores }\end{array}$} & $\begin{array}{l}\text { Apresentado } \\
\text { pelos autores }\end{array}$ & $\begin{array}{l}\text { “possa realizar pesquisas científicas sendo capaz de criar e modificar o } \\
\text { ambiente que o cerca. Nessa perspectiva a alfabetização científica, surge da } \\
\text { necessidade de construir cidadãos capazes de intervir na sociedade, se } \\
\text { apropriando dos conceitos científicos de modo que consigam interpretá-los, } \\
\text { estabelecer uma relação crítica frente às problemáticas que os envolvem e } \\
\text { aplicar seus conhecimentos de forma responsável e produtiva tanto em aspectos } \\
\text { científicos como tecnológicos” “a alfabetização científica é definida como } \\
\text { essencial no processo de formação do sujeito como cidadão, por meio dela a } \\
\text { pessoa é capaz de incitar mudanças significativas, atuando ativamente na } \\
\text { sociedade da qual faz parte.” “meio de instrução para o indivíduo compreender } \\
\text { as decisões realizadas em sociedade, e poder participar de debates públicos que } \\
\text { envolvam ciência.” “uma pessoa alfabetizada é capaz de incorporar essas } \\
\text { técnicas influenciando seu meio.” }\end{array}$ \\
\hline & Compreensão & $\begin{array}{l}\text { Estas foram algumas das definições de cidadania e Alfabetização científica } \\
\text { usada pelos autores. }\end{array}$ \\
\hline
\end{tabular}

Fonte: Bondezan (2019).

Tabela 36 - Ficha de análise do trabalho Batista, Assis e Travain (2017)

\begin{tabular}{|c|c|c|}
\hline $\begin{array}{l}\text { Eixo de } \\
\text { Análise }\end{array}$ & & Informações extraídas e comentários \\
\hline \multirow{2}{*}{$\begin{array}{l}\text { Tema de } \\
\text { Referência }\end{array}$} & $\begin{array}{l}\text { Apresentado } \\
\text { pelos autores }\end{array}$ & Efeito fotoelétrico \\
\hline & Compreensão & $\begin{array}{l}\text { Este tema é extremamente pontual e restrito, o que o torna bastante distante de } \\
\text { uma abordagem mais ampla, visando a cidadania, por exemplo. }\end{array}$ \\
\hline \multirow[t]{2}{*}{$\begin{array}{l}\text { Relação do } \\
\text { professor com } \\
\text { o } \\
\text { conhecimento } \\
\text { científico }\end{array}$} & $\begin{array}{l}\text { Apresentado } \\
\text { pelos autores }\end{array}$ & $\begin{array}{l}\text { “Para situar o aluno nesse mundo científico, faz-se necessário introduzir no } \\
\text { currículo alguns conceitos da Física Moderna, a qual aborda conteúdos } \\
\text { fundamentais para a explicação do funcionamento da tecnologia e a produção } \\
\text { de uma nova ciência.” “propomos a utilização de experimentos em uma aula } \\
\text { dialogada expositiva que, consiste na exposição de conteúdo com uma } \\
\text { participação ativa dos alunos e levando em consideração a bagagem de } \\
\text { conhecimento que eles trazem.” }\end{array}$ \\
\hline & Compreensão & $\begin{array}{l}\text { A proposta tem como fio condutor o conhecimento científico na forma do efeito } \\
\text { fotoelétrico. O aparato experimental aparecerá apenas na terceira aula realizada } \\
\text { e com relação um tanto distante com o cotidiano direto dos alunos. }\end{array}$ \\
\hline \multirow[t]{2}{*}{$\begin{array}{l}\text { Engajamento } \\
\text { dos alunos }\end{array}$} & $\begin{array}{l}\text { Apresentado } \\
\text { pelos autores }\end{array}$ & $\begin{array}{l}\text { “Após a resposta do professor, alguns alunos ficaram inquietos, tentando } \\
\text { entender porque existe frequência que não aciona o motor. Com o diálogo } \\
\text { constituído, o professor pôde mostrar o experimento e os fenômenos de } \\
\text { radiação eletromagnéticos envolvidos, possibilitando uma troca de } \\
\text { conhecimento entre os próprios alunos.” "Destacamos ainda que, na discussão } \\
\text { sobre o uso racional de energia elétrica a partir da abordagem da aplicação do } \\
\text { efeito fotoelétrico no cotidiano, os alunos participaram ativamente da discussão } \\
\text { sobre as fontes e da utilização de energia elétrica, demostrando terem refletido } \\
\text { acerca dos problemas enfrentados pelo uso irracional da energia e das soluções } \\
\text { relativas aos problemas apresentados, o que pode ter propiciado uma formação } \\
\text { científica articulada aos aspectos tecnológicos, sociais e ambientais.” }\end{array}$ \\
\hline & Compreensão & Segundo o relato dos autores, "os alunos participaram ativamente” \\
\hline
\end{tabular}




\begin{tabular}{|c|c|c|}
\hline $\begin{array}{l}\text { Eixo de } \\
\text { Análise }\end{array}$ & & Informações extraídas e comentários \\
\hline \multirow[t]{2}{*}{$\begin{array}{l}\text { Atividades } \\
\text { desenvolvidas } \\
\text { em sala }\end{array}$} & $\begin{array}{l}\text { Apresentado } \\
\text { pelos autores }\end{array}$ & $\begin{array}{l}\text { Na primeira aula foi realizada uma apresentação e aplicação do questionário } \\
\text { introdutório. Nas duas aulas seguintes foram realizadas explicações sobre o } \\
\text { efeito fotoelétrico com uso de física quântica. Nas duas aulas seguintes foi feita } \\
\text { a demonstração e análise do experimento “motor acionado por luz”, contando } \\
\text { com participação dos alunos e identificação de suas concepções alternativas. Na } \\
\text { aula seguinte foram feitas discussões sobre a abordagem CTS (envolvendo, } \\
\text { principalmente, exemplos de aplicação do fenômeno no cotidiano) e nova } \\
\text { apresentação do experimento. Na última aula foi feita uma revisão de conteúdo } \\
\text { e aplicação do segundo questionário. }\end{array}$ \\
\hline & Compreensão & $\begin{array}{c}\text { Foram várias as discussões sobre os experimentos realizados e apareceram } \\
\text { atividades de levantamento de concepç̃es prévias. Nenhuma atividade de } \\
\text { elaboração foi solicitada aos alunos. }\end{array}$ \\
\hline \multirow[t]{2}{*}{$\begin{array}{l}\text { Participação } \\
\text { na sociedade } \\
\text { que os alunos } \\
\text { desenvolvem }\end{array}$} & $\begin{array}{l}\text { Apresentado } \\
\text { pelos autores }\end{array}$ & $\begin{array}{l}\text { A sexta aula foi “dialogada com discussões sobre a abordagem CTS e nova } \\
\text { apresentação do experimento” em que "o professor utilizou novamente o } \\
\text { experimento para mostrar aos alunos sua aplicação em equipamentos } \\
\text { tecnológicos, como por exemplo: no acionamento de portas automáticas, na } \\
\text { interrupção de motores prevendo acidentes, na iluminação de ruas, em sensores } \\
\text { eletrônicos de presença, entre outros. Nessa aula, o professor possibilitou a } \\
\text { discussão dos fenômenos físicos e os alunos assumiram uma postura ativa } \\
\text { durante o diálogo, levantando dúvidas e trazendo seu conhecimento prévio } \\
\text { sobre o assunto.” “por meio de questões associadas à importância da aplicação } \\
\text { dos conceitos de radiação eletromagnética e energia para o desenvolvimento } \\
\text { tecnológico aplicado em aparelhos eletrônicos utilizados na sociedade. Usamos } \\
\text { como exemplo o sistema das luminárias nos postes que opera de acordo com o } \\
\text { efeito fotoelétrico, em que os alunos puderam debater sobre os pontos positivos } \\
\text { e negativos desse tipo de iluminação.” }\end{array}$ \\
\hline & Compreensão & $\begin{array}{l}\text { O excerto acima contém a atividade realizada pelos alunos com abordagem } \\
\text { CTS, segundo os autores. É possível perceber, assim, que a abordagem CTS, } \\
\text { para os autores, estaria próxima ao cotidiano dos alunos e ao fazer experimental } \\
\text { com protagonismo deles. Os alunos debatem sobre os pontos positivos e } \\
\text { negativos das luminárias movidas a painel solar, talvez de maneira pontual. }\end{array}$ \\
\hline \multirow{2}{*}{$\begin{array}{l}\text { Contexto da } \\
\text { prática } \\
\text { docente }\end{array}$} & $\begin{array}{l}\text { Apresentado } \\
\text { pelos autores }\end{array}$ & $\begin{array}{l}\text { "alunos de uma sala da 3a série do Ensino Médio, em uma escola da rede } \\
\text { estadual de ensino localizada no Vale do Paraíba. Essa sequência foi aplicada } \\
\text { pelo professor de física, em um total de sete aulas” } 35 \text { alunos, aula de Física }\end{array}$ \\
\hline & Compreensão & $\begin{array}{l}\text { A proposta foi desenvolvida em sete aulas em contexto regular e não parece ter } \\
\text { sofrido grande influência do currículo da escola. }\end{array}$ \\
\hline
\end{tabular}




\begin{tabular}{|c|c|c|}
\hline $\begin{array}{l}\text { Eixo de } \\
\text { Análise }\end{array}$ & & Informações extraídas e comentários \\
\hline \multirow[t]{2}{*}{$\begin{array}{c}\text { Cidadania } \\
\text { apresentada } \\
\text { pelos autores }\end{array}$} & $\begin{array}{l}\text { Apresentado } \\
\text { pelos autores }\end{array}$ & $\begin{array}{l}\text { “'No diálogo, as ideias vão tomando corpo, tornando-se mais precisas. O } \\
\text { conflito de pontos de vista aguça o espírito crítico, estimula a revisão das } \\
\text { opiniões, contribui para relativizar posições [...]. É neste momento do diálogo e } \\
\text { da reflexão que os alunos tomam consciência de sua atividade cognitiva, dos } \\
\text { procedimentos de investigação que utilizaram aprendendo a geri-los e } \\
\text { aperfeiçoá-lo.”” “(nas) atividades investigativas (...) o estudante (...) percebe o } \\
\text { seu papel fundamental na construção do conhecimento em aula, abandonando } \\
\text { uma postura passiva e tornando-se crítico, adquirindo a liberdade de questionar, } \\
\text { relatar acontecimentos e buscar as causas dessas relações, o que dá ao seu } \\
\text { trabalho características de uma investigação científica.” "Buscando um ensino } \\
\text { interdisciplinar, o currículo de Ensino de Ciências vem abordando temas que } \\
\text { envolvem tecnologia, sociedade e ambiente, com o intuito de que o aluno } \\
\text { desenvolva, por meio da ciência, o pensamento crítico em relação a problemas } \\
\text { sociais e ambientais enfrentados pela a sociedade que está inserido.” ““(i) A } \\
\text { busca por um ensino que contribua para uma mudança da compreensão do } \\
\text { status da ciência, que envolve preparar os estudantes para compreender o papel } \\
\text { que a ciência e a tecnologia exercem na sociedade e vice-versa. (ii) O } \\
\text { desenvolvimento de uma aprendizagem social, entendida como a formação de } \\
\text { cidadãos capazes de utilizar os conhecimentos escolares, que deixam de ser } \\
\text { apenas científicos, já que envolvem questões mais humanistas e culturais, para } \\
\text { se posicionar criticamente e decidir sobre questões relacionadas à ciência e à } \\
\text { tecnologia.”” }\end{array}$ \\
\hline & Compreensão & Nada a comentar \\
\hline \multirow{2}{*}{\multicolumn{3}{|c|}{ Tabela 37 - Ficha de análise do trabalho Terra e Leite (2017) }} \\
\hline & & \\
\hline $\begin{array}{l}\text { Eixo de } \\
\text { Análise }\end{array}$ & & Informações extraídas e comentários \\
\hline \multirow{2}{*}{$\begin{array}{l}\text { Tema de } \\
\text { Referência }\end{array}$} & $\begin{array}{l}\text { Apresentado } \\
\text { pelos autores }\end{array}$ & “produção artesanal de vinagre a partir de caldo de cana” \\
\hline & Compreensão & $\begin{array}{l}\text { O tema de referência é bastante localizado e curricular, dificultando qualquer } \\
\text { abordagem mais geral ou cidadã. }\end{array}$ \\
\hline \multirow{2}{*}{$\begin{array}{l}\text { Relação do } \\
\text { professor com } \\
\quad \text { o } \\
\text { conhecimento } \\
\text { científico }\end{array}$} & $\begin{array}{l}\text { Apresentado } \\
\text { pelos autores }\end{array}$ & $\begin{array}{l}\text { “O objetivo deste trabalho foi o de estudar a construção social da ciência e } \\
\text { tecnologia olhando para a produção artesanal de vinagre a partir de caldo de } \\
\text { cana, a fim de promover uma educação química interdisciplinar e } \\
\text { transdisciplinar.” O objetivo da atividade é: "promover atividades investigativas } \\
\text { sobre a produção de vinagre, favorecendo o processo de ensino-aprendizagem } \\
\text { de química e contribuindo para apropriação de conhecimentos } \\
\text { interdisciplinar/transdisciplinar das ciências da natureza.” }\end{array}$ \\
\hline & Compreensão & $\begin{array}{l}\text { A produção de vinagre certamente é mais central para a atividade do que os } \\
\text { conhecimentos químicos. Esta produção parece ser algo ou muito próximo do } \\
\text { cotidiano dos alunos, que presenciam a produção caseira deste líquido, ou } \\
\text { próxima culturalmente da comunidade. A relação com a cidadania propriamente } \\
\text { dita parece estar em segundo plano. }\end{array}$ \\
\hline
\end{tabular}




\begin{tabular}{|c|c|c|}
\hline $\begin{array}{l}\text { Eixo de } \\
\text { Análise }\end{array}$ & & Informações extraídas e comentários \\
\hline $\begin{array}{c}\text { Engajamento } \\
\text { dos alunos }\end{array}$ & $\begin{array}{l}\text { Apresentado } \\
\text { pelos autores }\end{array}$ & $\begin{array}{l}\text { “A intervenção pedagógica permitiu estabelecer um diálogo entre o processo } \\
\text { artesanal de produção de vinagre e o contexto escolar, considerando a cultura } \\
\text { dos estudantes e as histórias de famílias. Algumas dessas histórias foram } \\
\text { confrontadas quando os estudantes conheceram a teoria do processo, como por } \\
\text { exemplo a necessidade de se manter o sistema fechado e isolado, sem contato } \\
\text { com ar. Ao longo de toda a prática pedagógica os estudantes conversaram com } \\
\text { familiares e a professora de química da escola, promovendo o confronte entre } \\
\text { saberes escolares com saberes científicos e populares.” “O tema sociocientífico } \\
\text { de produção artesanal de vinagre promoveu debates sobre a educação química } \\
\text { relacionando experiências cotidianas, imagens, uso da internet e entrevistas } \\
\text { com familiares” }\end{array}$ \\
\hline
\end{tabular}

Não é possível afirmar, com certeza, qual o nível da motivação dos estudantes

Compreensão durante a abordagem, uma vez que não são mencionados detalhes de suas falas ou motivações. No entanto, devido ao fato dos estudantes terem seus conhecimentos e de suas famílias valorizados, é provável que eles tenham sido mais do que burocraticamente mobilizados.

Três momentos pedagógicos. Nas seis primeiras aulas foi realizada a problematização, com uma roda de conversa para identificar a tradição de produção de vinagre na cidade, a pesquisa de informações nutricionais em embalagens de vinagre, a exibição de um vídeo sobre a fabricação deste produto e uma avaliação individual. Nas nove aulas seguintes foi realizada a organização do conhecimento, com aulas expositivas e dialogadas, com a apresentação de slides e estudo com consulta à internet e a artigos científicos.

Atividades Apresentado Os assuntos estudados incluíram conceitos de química como funções orgânicas Atividades pelos autores e reações de fermentação. Foram incluídas nas discussões alguns aspectos desenvolvidas "socioeconômicos, socioculturais e socioambientais” do que era estudado. Nas em sala seis últimas aulas foi realizada a aplicação do conhecimento, com a produção artesanal de vinagre, confecção de relatório das aulas práticas e "construção

coletiva de um seminário em grupo”. Segundo os autores, ao final da experiência "foram discutidas as questões socioeconômicas relativa a queda da qualidade do vinagre final, como valor de mercado, competição de processos artesanal e industrial, automação das indústrias, entre outros assuntos.”

Compreensão Foram vários os tipos de atividades realizadas, com os alunos assumindo diversas posições.

"foram discutidas as questões socioeconômicas relativa a queda da qualidade do vinagre final, como valor de mercado, competição de processos artesanal e industrial, automação das indústrias, entre outros assuntos." "houve uma discussão sobre o destino dos efluentes desses processos bioquímicos. (...)

Apresentado haverá rejeitos de bagaço de cana, que podem ser utilizados em fornos. Quando pelos autores há destilação do fermentado do vinho, rico em álcool em álcool etílico, o

Participação na sociedade que os alunos desenvolvem vinhoto é o principal rejeito do processo, que pode comprometer o sistemas hídricos e lençol freático. (...) aproveitamento de vinhoto como adubo orgânico em lavouras de hortaliças (...) a produção de vinagre pode gerar material gelatinoso, rico em colônias de bactérias (...), que também pode ser utilizado como adubo ao final do processo."

Há certamente uma preocupação com o ambiente, com a necessidade de se Compreensão $\begin{gathered}\text { diminuir os danos causados pelos subprodutos da produção do vinagre. Esta } \\ \text { preocupação, porém não tenta incluir os órgão governamentais reguladores, ou }\end{gathered}$ investigar as implicações mais diretas à economia e à saúde dos habitantes. 


\begin{tabular}{|c|c|c|}
\hline $\begin{array}{l}\text { Eixo de } \\
\text { Análise }\end{array}$ & & Informações extraídas e comentários \\
\hline \multirow{2}{*}{$\begin{array}{l}\text { Contexto da } \\
\text { prática } \\
\text { docente }\end{array}$} & $\begin{array}{l}\text { Apresentado } \\
\text { pelos autores }\end{array}$ & $\begin{array}{l}\text { “escola da Rede Federal de Educação Profissional e Tecnológica do Estado do } \\
\text { Espírito Santo, envolvendo duas turmas com } 35 \text { estudantes de ensino técnico de } \\
\text { nível médio.” disciplina de química num total de } 21 \text { aulas. }\end{array}$ \\
\hline & Compreensão & $\begin{array}{l}\text { As atividades se desenvolveram em várias aulas e não foi mencionada nenhuma } \\
\text { pressão do currículo pré estabelecido. }\end{array}$ \\
\hline \multirow[t]{2}{*}{$\begin{array}{l}\text { Cidadania } \\
\text { apresentada } \\
\text { pelos autores }\end{array}$} & $\begin{array}{l}\text { Apresentado } \\
\text { pelos autores }\end{array}$ & $\begin{array}{l}\text { “De que maneira os aspectos tecnológicos, sociocientíficos, socioeconômicos, } \\
\text { socioculturais e socioambientais podem ser entrelaçados pela temática } \\
\text { 'produção de vinagre’?” "as práticas devem tratar inicialmente de } \\
\text { problemas/temáticas sociocientíficas, seguidas de abordagens teóricas, } \\
\text { abordagens práticas e, finalmente, debates com pessoas de notório saber.” “A } \\
\text { educação CTS/CTSA, de acordo com Aikenhead (1997), quando é } \\
\text { desenvolvida na perspectiva de estudos culturais de ciência transcultural, pode } \\
\text { promover conexões de saberes na fronteira do conhecimento, ampliando a visão } \\
\text { de mundo, contribuindo para eliminar preconceitos existentes na humanidade e } \\
\text { conscientizar a população sobre o papel da ciência.” }\end{array}$ \\
\hline & Compreensão & Nada a comentar \\
\hline \multirow{2}{*}{\multicolumn{3}{|c|}{ Tabela 38 - Ficha de análise do trabalho Silva et al. (2017) }} \\
\hline & & \\
\hline $\begin{array}{l}\text { Eixo de } \\
\text { Análise }\end{array}$ & & Informações extraídas e comentários \\
\hline \multirow{2}{*}{$\begin{array}{l}\text { Tema de } \\
\text { Referência }\end{array}$} & $\begin{array}{l}\text { Apresentado } \\
\text { pelos autores }\end{array}$ & “remediação ambiental de áreas contaminadas” \\
\hline & Compreensão & $\begin{array}{l}\text { A temática é bastante ligada ao meio ambiente, sua conservação e diminuição } \\
\text { de danos causados por humanos. Além disso, ela é bastante ampla e passível de } \\
\text { ser trabalhada do ponto de vista da cidadania. }\end{array}$ \\
\hline \multirow{2}{*}{$\begin{array}{l}\text { Relação do } \\
\text { professor com } \\
\quad \text { o } \\
\text { conhecimento } \\
\text { científico }\end{array}$} & $\begin{array}{l}\text { Apresentado } \\
\text { pelos autores }\end{array}$ & $\begin{array}{c}\text { “a questão que norteia essa pesquisa é: ‘Quais as potencialidades da abordagem } \\
\text { CTSA com o tema problematizador 'remediação ambiental de áreas } \\
\text { contaminadas’ no processo ensino-aprendizagem de estudantes de Ensino } \\
\text { Médio?’” }\end{array}$ \\
\hline & Compreensão & $\begin{array}{l}\text { O conhecimento científico aparece certamente do ponto de vista ambiental, mas } \\
\text { acaba por se aproximar mais do cotidiano do que da cidadania, que aparece de } \\
\text { maneira mais intensa apenas no debate. }\end{array}$ \\
\hline \multirow{2}{*}{$\begin{array}{l}\text { Engajamento } \\
\text { dos alunos }\end{array}$} & $\begin{array}{l}\text { Apresentado } \\
\text { pelos autores }\end{array}$ & $\begin{array}{c}\text { “A abordagem de uma proposta baseada na perspectiva CTSA, proporcionou } \\
\text { aos alunos o desenvolvimento de sua argumentação, e consequentemente do seu } \\
\text { posicionamento crítico frente a situações-problemas, como pode ser observado } \\
\text { na sequencia apresentada neste trabalho” }\end{array}$ \\
\hline & Compreensão & $\begin{array}{c}\text { Não é possível inferir com certeza qual o nível de engajamento dos alunos } \\
\text { diante da abordagem. É possível afirmar, apenas, que eles responderam bem à } \\
\text { atividade, isto é, participaram com bom nível de argumentação no debate e } \\
\text { mobilizaram vários dos conteúdos estudados. }\end{array}$ \\
\hline
\end{tabular}




\begin{tabular}{|c|c|c|}
\hline $\begin{array}{l}\text { Eixo de } \\
\text { Análise }\end{array}$ & & Informações extraídas e comentários \\
\hline \multirow[t]{2}{*}{$\begin{array}{l}\text { Atividades } \\
\text { desenvolvidas } \\
\text { em sala }\end{array}$} & $\begin{array}{l}\text { Apresentado } \\
\text { pelos autores }\end{array}$ & $\begin{array}{l}\text { Antes da sequência didática em si, “foi realizada uma avaliação diagnóstica } \\
\text { para verificar os conhecimentos prévios dos alunos a respeito do tema.” no } \\
\text { primeiro momento buscou-se “sensibilizar os alunos sobre a relevância da } \\
\text { remediação ambiental”, com a leitura de reportagens sobre solos contaminados } \\
\text { em um condomínio residencial. No segundo momento foram apresentados } \\
\text { vídeos sobre áreas degradadas para que os estudantes conhecessem as } \\
\text { principais substâncias que contaminam o solo. Ainda neste momento, os } \\
\text { estudantes deveriam escrever uma redação individual com o tema ““como a } \\
\text { contaminação do meio ambiente afeta a sociedade?’” No terceiro momento foi } \\
\text { realizada uma aula expositiva para que os alunos entendessem como funcionam } \\
\text { as principais técnicas de remediação. No quarto e último momento foram } \\
\text { realizadas leituras de artigos e reportagens com consequências do acidente de } \\
\text { Mariana e possíveis ações de remediação dessas áreas. Também neste momento } \\
\text { da sequência, os alunos foram organizados em grupos de defesa e de acusação } \\
\text { para um debate sobre a culpa das companhias Vale do Rio Doce e Samarco no } \\
\text { desastre de Mariana. }\end{array}$ \\
\hline & Compreensão & Foram várias e diversificadas as atividades desenvolvidas em sala. \\
\hline \multirow{2}{*}{$\begin{array}{l}\text { Participação } \\
\text { na sociedade } \\
\text { que os alunos } \\
\text { desenvolvem }\end{array}$} & $\begin{array}{l}\text { Apresentado } \\
\text { pelos autores }\end{array}$ & $\begin{array}{l}\text { Atividades expositivas que incentivavam os alunos a compreenderem os vários } \\
\text { aspectos da natureza e a remediação na tentativa de minimizar os impactos } \\
\text { causados pela ação humana. Debate sobre a culpa da Samarco no desastre de } \\
\text { Mariana. }\end{array}$ \\
\hline & Comp & $\begin{array}{c}\text { As primeiras atividades realizadas pareceram ter relação um tanto indireta com } \\
\text { a cidadania, não incentivando uma relação coletiva com a sociedade. A última } \\
\text { atividade, o debate sobre o desastre de Mariana, por outro lado, incentivou que } \\
\text { os alunos se posicionassem de maneira crítica e coletiva perante a temática } \\
\text { ambiental. }\end{array}$ \\
\hline \multirow{2}{*}{$\begin{array}{l}\text { Contexto da } \\
\text { prática } \\
\text { docente }\end{array}$} & $\begin{array}{l}\text { Apresentado } \\
\text { pelos autores }\end{array}$ & “45 alunos da $1^{\text {a }}$ série do Ensino Médio de uma escola estadual de São Paulo” \\
\hline & Compreensão & $\begin{array}{l}\text { Embora não tenha sido mencionado o número de aulas usadas nas atividades, é } \\
\text { possível supor que elas tenham sido pelo menos seis, devido ao grande número } \\
\text { de tarefas realizadas. A rigidez curricular também não foi mencionada. }\end{array}$ \\
\hline $\begin{array}{l}\text { Cidadania } \\
\text { apresentada } \\
\text { pelos autores }\end{array}$ & $\begin{array}{l}\text { Apresentado } \\
\text { pelos autores }\end{array}$ & $\begin{array}{l}\text { “o principal objetivo de um currículo que contemple a CTSA é desenvolver a } \\
\text { capacidade de tomada de decisão e, além disso, enfatizar questões ambientais, } \\
\text { visando à promoção da educação ambiental (SANTOS, 2007).” } \\
\text { “desenvolvendo também seu posicionamento crítico perante os problemas } \\
\text { presentes em seu contexto social” “a remediação ambiental (...) apresenta } \\
\text { potencial para o desenvolvimento da reflexão crítica, proporcionando uma } \\
\text { educação problematizadora.” “a Educação Ambiental é considerada (...) como } \\
\text { uma preocupação dos movimentos ecológicos com a prática de conscientização } \\
\text { (...) assim como (...) envolver os cidadãos em ações sociais ambientalmente } \\
\text { apropriadas.” “.A perspectiva CTSA (...) fazendo com que os estudantes } \\
\text { entendam com mais facilidade o papel da ciência em seu ambiente } \\
\text { socioambiental (...) essa abordagem visa proporcionar aos discentes uma maior } \\
\text { conscientização a respeito das relações entre Ciência, Tecnologia, Sociedade e } \\
\text { Ambiente, rompendo com a imagem neutra da Ciência, desenvolvendo o } \\
\text { posicionamento crítico e a tomada de decisão dos alunos frente a problemas } \\
\text { existentes em seu contexto social.” }\end{array}$ \\
\hline
\end{tabular}

Compreensão Foram várias as expressões sobre a concepção de cidadania que os autores têm.

Fonte: Bondezan (2019). 
Tabela 39 - Ficha de análise do trabalho Santana, Terra e Leite (2017)

\begin{tabular}{|c|c|c|}
\hline $\begin{array}{l}\text { Eixo de } \\
\text { Análise }\end{array}$ & & Informações extraídas e comentários \\
\hline \multirow{2}{*}{$\begin{array}{l}\text { Tema de } \\
\text { Referência }\end{array}$} & $\begin{array}{l}\text { Apresentado } \\
\text { pelos autores }\end{array}$ & Produção de açúcar \\
\hline & Compreensão & $\begin{array}{c}\text { A produção de açúcar é um tema não curricular, mas extremamente localizado e } \\
\text { com abordagens mais gerais, apesar de possíveis, como retrata o presente } \\
\text { trabalho, bastante difíceis. }\end{array}$ \\
\hline \multirow[t]{2}{*}{$\begin{array}{l}\text { Relação do } \\
\text { professor com } \\
\text { o } \\
\text { conhecimento } \\
\text { científico }\end{array}$} & $\begin{array}{l}\text { Apresentado } \\
\text { pelos autores }\end{array}$ & $\begin{array}{l}\text { “O objetivo deste trabalho foi o de estudar os aspectos metodológicos de ensino } \\
\text { e a educação CTS/CTSA promovida a partir da realização de uma sequência de } \\
\text { ensino investigativo de química para debater a temática de produção de açúcar.” } \\
\text { “A temática de produção artesanal de açúcar mascavo foi inspirada na tradição } \\
\text { das lanchonetes da cidade de Ibiraçu-ES, que oferecem o pastel e o caldo de } \\
\text { cana como produto principal.” }\end{array}$ \\
\hline & Compreensão & $\begin{array}{c}\text { A motivação das atividades realizadas é a existência das lanchonetes, portanto, } \\
\text { cotidiana. }\end{array}$ \\
\hline \multirow[t]{2}{*}{$\begin{array}{l}\text { Engajamento } \\
\text { dos alunos }\end{array}$} & $\begin{array}{l}\text { Apresentado } \\
\text { pelos autores }\end{array}$ & $\begin{array}{l}\text { “Ao final, os grupos fizeram uma tabela de valores de massa de açúcar nos } \\
\text { produtos alimentícios, usando regra de três e calculadoras. Os resultados dos } \\
\text { cálculos surpreenderam os estudantes, pois estes fazem consumo diário desses } \\
\text { produtos.” “Esse ambiente não-escolar se tornou um espaço educativo a partir } \\
\text { da intencionalidade da prática pedagógica e da disposição de diálogo dos } \\
\text { estudantes com o produtor rural” }\end{array}$ \\
\hline & Compreensão & $\begin{array}{l}\text { Não é explicitada a forma como os alunos reagiram a atividade como um todo, } \\
\text { mas a passagem citada, bem como o aprendizado dos alunos, verificado em } \\
\text { vários momentos, nos dão indícios de que o engajamento dos alunos foi pelo } \\
\text { menos parcial. }\end{array}$ \\
\hline \multirow[t]{2}{*}{$\begin{array}{l}\text { Atividades } \\
\text { desenvolvidas } \\
\text { em sala }\end{array}$} & $\begin{array}{l}\text { Apresentado } \\
\text { pelos autores }\end{array}$ & $\begin{array}{l}\text { Nas três primeiras aulas de } 100 \text { minutos, foi realizada a problematização inicial, } \\
\text { com uso de roda de conversa para destacar a importância do caldo de cana e da } \\
\text { produção de açúcar para a região, pesquisar as informações nutricionais nas } \\
\text { embalagens de alimentos, assim como calcular e reunir seu equivalente em } \\
\text { açúcar, e exibição de um vídeo sobre o ciclo da cana-de-açúcar, com grande } \\
\text { ênfase nos aspectos históricos. Nas quatro aulas subsequentes foi realizada a } \\
\text { organização do conhecimento, com aulas expositivas e dialogadas, com a } \\
\text { apresentação de slides e estudo com consulta à internet e a artigos científicos. } \\
\text { Os conteúdos curriculares foram os processos de evaporação e cristalização, } \\
\text { assim como “alguns aspectos socioeconômicos, socioculturais e } \\
\text { socioambientais” e a “química do açúcar”. Nas duas últimas aulas foi feita a } \\
\text { visita a uma fábrica artesanal de açúcar, um relatório das aulas práticas e } \\
\text { seminário. }\end{array}$ \\
\hline & Compreensão & As atividades realizadas foram bastante variadas. \\
\hline
\end{tabular}




\begin{tabular}{|c|c|c|}
\hline $\begin{array}{l}\text { Eixo de } \\
\text { Análise }\end{array}$ & & Informações extraídas e comentários \\
\hline \multirow[t]{2}{*}{$\begin{array}{l}\text { Participação } \\
\text { na sociedade } \\
\text { que os alunos } \\
\text { desenvolvem }\end{array}$} & $\begin{array}{l}\text { Apresentado } \\
\text { pelos autores }\end{array}$ & $\begin{array}{l}\text { “Sadler (2011) ressalta que as práticas escolares usando questões } \\
\text { sociocientíficas (...) pode promover debates a partir de experiências de } \\
\text { laboratório, experiências cotidianas, imagens, com a ajuda da internet e de } \\
\text { visitas guiadas. Reis e Galvão (2008) sugerem o uso de questões } \\
\text { sociocientíficas para provocar discussões incluindo conteúdos de ciências de } \\
\text { natureza articulados as questões socioculturais, socioambientais, } \\
\text { sociofilosóficas, socioeconômicas, entre outras, de tal maneira que as pessoas } \\
\text { envolvidas no debate sejam forçadas a se posicionar, proporcionando reflexão } \\
\text { sobre conceitos, crenças, valores, mitos etc.” “Também foram abordadas as } \\
\text { questões socioeconômicas em relação ao Brasil e ao mundo, como a produção } \\
\text { sazonal de açúcar, o valor de mercado do açúcar, competição para a produção } \\
\text { de álcool etílico, desemprego, automação das indústrias, entre outros assuntos.” }\end{array}$ \\
\hline & Compreensão & $\begin{array}{l}\text { Há, certamente, um desejo dos autores de realizar um diálogo entre o } \\
\text { conhecimento científico e suas múltiplas relações com a sociedade. Estas } \\
\text { relações com a sociedade parecem ser apenas em nível individual e pouco ativo, } \\
\text { a exceção da última discussão. }\end{array}$ \\
\hline \multirow{2}{*}{$\begin{array}{l}\text { Contexto da } \\
\text { prática } \\
\text { docente }\end{array}$} & $\begin{array}{l}\text { Apresentado } \\
\text { pelos autores }\end{array}$ & $\begin{array}{c}\text { “A intervenção de ensino envolveu } 15 \text { estudantes de ensino médio da Rede } \\
\text { Estadual de Educação Básica do Estado do Espírito Santo.” Foram realizadas } \\
\text { um total de } 18 \text { aulas }\end{array}$ \\
\hline & Compreensão & $\begin{array}{c}\text { Foram utilizadas } 18 \text { aulas para a realização das atividades. A rigidez curricular } \\
\text { não foi mencionada. }\end{array}$ \\
\hline
\end{tabular}

“Neste trabalho, focamos numa intervenção pedagógica de Ciências da Natureza, abordando estudos culturais sobre a construção social da ciência e tecnologia, também chamado de educação (...) CTSA" "De acordo com Aikenhead (...), a educação CTS/CTSA é fruto da produção de conhecimento científico e assume uma perspectiva interdisciplinar e transdisciplinar, tratada

Cidadania apresentada pelos autores
Apresentado pelo autor como sendo a ciência transcultural, promovendo conexões de saberes pelos autores na fronteira do conhecimento.” "De que maneira os aspectos tecnológicos, sociocientíficos, socioeconômicos, socioculturais e socioambientais podem ser entrelaçados pela temática 'produção de açúcar'?” “O objetivo deste trabalho foi o de estudar os aspectos metodológicos de ensino e a educação CTS/CTSA promovida a partir da realização de uma sequência de ensino investigativo de química para debater a temática de produção de açúcar.”

Compreensão
A CTSA assim como as várias abordagens aqui reunidas em “Questões” são a motivação da abordagem.

$$
\text { Fonte: Bondezan (2019). }
$$

Tabela 40 - Ficha de análise do trabalho Pereira et al. (2017)

\begin{tabular}{ccc}
\hline $\begin{array}{c}\text { Eixo de } \\
\text { Análise }\end{array}$ & Informações extraídas e comentários \\
\hline & $\begin{array}{c}\text { Apresentado } \\
\text { pelos autores }\end{array}$ & "Matriz Energética Brasileira” \\
\cline { 2 - 3 } $\begin{array}{c}\text { Tema de } \\
\text { Referência }\end{array}$ & Compreensão & $\begin{array}{c}\text { O tema “matriz energética” é bastante amplo, não estando restrito a nenhuma } \\
\text { disciplina curricular ou conhecimento científico pré estabelecido, possuindo } \\
\text { bastante potencialidade para abordagens cidadãs. }\end{array}$ \\
\hline
\end{tabular}




\begin{tabular}{|c|c|c|}
\hline $\begin{array}{l}\text { Eixo de } \\
\text { Análise }\end{array}$ & & Informações extraídas e comentários \\
\hline \multirow{2}{*}{$\begin{array}{l}\text { Relação do } \\
\text { professor com } \\
\text { o } \\
\text { conhecimento } \\
\text { científico }\end{array}$} & $\begin{array}{l}\text { Apresentado } \\
\text { pelos autores }\end{array}$ & $\begin{array}{c}\text { “O presente artigo traz uma pesquisa por investigação do conceito Energia por } \\
\text { meio da utilização do documentário ‘Power’” “A abordagem CTS (...) busca } \\
\text { contextualizar o Ensino de Ciência por meio de discussões de questões que } \\
\text { emergem do cotidiano do estudante, fazendo relações coerentes entre a ciência, } \\
\text { a tecnologia e a sociedade.” }\end{array}$ \\
\hline & Compreensão & $\begin{array}{l}\text { O trabalho parece partir do conceito cotidiano de energia e do documentário, } \\
\text { que também estaria bastante próximo ao cotidiano. A cidadania e os conteúdos } \\
\text { curriculares aparecem em segundo plano. }\end{array}$ \\
\hline \multirow[t]{2}{*}{$\begin{array}{l}\text { Engajamento } \\
\text { dos alunos }\end{array}$} & $\begin{array}{l}\text { Apresentado } \\
\text { pelos autores }\end{array}$ & $\begin{array}{l}\text { “O documentário chamou muito a atenção dos estudantes, pois faziam } \\
\text { anotações e em nenhum momento houve conversas paralelas ou falta de } \\
\text { interesse em assistir. No final queriam conversar e discutir sobre o que tinham } \\
\text { visto" “as atitudes tomadas e vivenciadas em todas as etapas desse trabalho } \\
\text { exprimem muita criatividade, criticidade e desenvolvimento na oralidade o que } \\
\text { emerge uma considerável mudança de comportamento no processo de } \\
\text { construção do conhecimento.” }\end{array}$ \\
\hline & Compreensão & $\begin{array}{l}\text { Os relatos feitos pelos autores nos indicam que os alunos foram bastante } \\
\text { motivados pelas atividades. }\end{array}$ \\
\hline \multirow[t]{2}{*}{$\begin{array}{l}\text { Atividades } \\
\text { desenvolvidas } \\
\text { em sala }\end{array}$} & $\begin{array}{l}\text { Apresentado } \\
\text { pelos autores }\end{array}$ & $\begin{array}{l}\text { No primeiro momento foi aplicado um questionário investigativo para } \\
\text { identificar as concepções dos estudantes sobre energia e sua produção. No } \\
\text { segundo momento os estudantes assistiram ao documentário “POWER: O } \\
\text { poder por trás da Energia” e realizaram uma breve discussão, que não foi } \\
\text { continuada por falta de tempo. No terceiro momento os estudantes realizaram } \\
\text { pesquisas sobre os cientistas e demais acontecimentos mencionados no } \\
\text { documentário. No quarto momento os estudantes foram divididos em grupos } \\
\text { para estudo das principais formas de produção de energia elétrica a partir de } \\
\text { aulas expositivas, textos disponibilizados pelo professor e em sites da internet. } \\
\text { Ainda nesse momento os alunos prepararam maquetes e seminários para } \\
\text { sistematizar os conhecimentos apreendidos e compartilhá-los com a sala. No } \\
\text { quinto momento os alunos apresentaram para a sala seus seminários e suas } \\
\text { maquetes. No sexto momento foram confeccionados e distribuídos panfletos } \\
\text { “para a comunidade escolar destacando a importância das mudanças de } \\
\text { posturas e participação crítica como cidadãos nas questões relacionadas à } \\
\text { produção e consumo de Energia, destacando a qualidade de vida das pessoas e } \\
\text { os impactos sociais, culturais, políticos e ambientais na sociedade.” Finalmente, } \\
\text { no sétimo momento, o questionário investigativo inicial foi reaplicado. }\end{array}$ \\
\hline & Compreensão & As atividades realizadas foram bastante variadas. \\
\hline \multirow{2}{*}{$\begin{array}{l}\text { Participação } \\
\text { na sociedade } \\
\text { que os alunos } \\
\text { desenvolvem }\end{array}$} & $\begin{array}{l}\text { Apresentado } \\
\text { pelos autores }\end{array}$ & $\begin{array}{l}\text { “construção de maquetes e montagem de seminários sobre: usina hidrelétrica, } \\
\text { usina nuclear, usina eólica e usina termoelétrica; apresentação de seminários e } \\
\text { maquetes; confecção e distribuição de folders sobre o consumo consciente de } \\
\text { energia e o aproveitamento das energias renováveis” “Assim, prevalece mesmo } \\
\text { que seja intrinsicamente, a visão positivista da ciência e da tecnologia que o } \\
\text { progresso da qualidade de vida está relacionado à economia, a maioria não se } \\
\text { preocupa em tomar decisões somente pelos benefícios da produção de energias } \\
\text { renováveis para a sua qualidade de vida e do planeta” }\end{array}$ \\
\hline & Compreensão & $\begin{array}{l}\text { Está bastante claro que os alunos agem de várias maneiras visando a } \\
\text { participação em sociedade. Principalmente na confecção e distribuição de } \\
\text { folders os alunos agem de maneira coletiva e ativa. Pela análise dos dados, } \\
\text { porém, parece que a compreensão dos estudantes sobre energia, sua forma de } \\
\text { obtenção e as ações que podemos tomar não foram suficientemente } \\
\text { problematizadas, ainda estando restritas a níveis pouco críticos. }\end{array}$ \\
\hline
\end{tabular}




\begin{tabular}{|c|c|c|}
\hline $\begin{array}{l}\text { Eixo de } \\
\text { Análise }\end{array}$ & & Informações extraídas e comentários \\
\hline \multirow{2}{*}{$\begin{array}{l}\text { Contexto da } \\
\text { prática } \\
\text { docente }\end{array}$} & $\begin{array}{l}\text { Apresentado } \\
\text { pelos autores }\end{array}$ & $\begin{array}{l}\text { "vinte e sete alunos do terceiro ano do ensino médio de uma escola pública do } \\
\text { município de Reserva/PR" }\end{array}$ \\
\hline & Compreensão & $\begin{array}{c}\text { Não é especificada a quantidade de aulas utilizadas para a realização das } \\
\text { atividades relatadas no trabalho, contudo, essa quantidade parece ser elevada. A } \\
\text { influência curricular não foi mencionada. }\end{array}$ \\
\hline \multirow[t]{2}{*}{$\begin{array}{l}\text { Cidadania } \\
\text { apresentada } \\
\text { pelos autores }\end{array}$} & $\begin{array}{l}\text { Apresentado } \\
\text { pelos autores }\end{array}$ & $\begin{array}{l}\text { “produção de energia elétrica e seus impactos ambientais, sociais, políticos e } \\
\text { econômicos” “instigar os estudantes por meio do documentário a reconhecer as } \\
\text { variadas formas de produção de energia e qual é a forma de produção de } \\
\text { energia menos impactante na sociedade, levando-os a tomarem algumas } \\
\text { decisões em relação ao uso e à produção de energia.” “A maior preocupação do } \\
\text { Ensino com o enfoque CTS é apresentar um ensino crítico e interdisciplinar que } \\
\text { leve o estudante a uma alfabetização científica para que possa ter condições } \\
\text { para participar efetivamente das decisões que envolvem questões sobre o } \\
\text { desenvolvimento científico e tecnológico.” "Evidenciando discussões em busca } \\
\text { do conhecimento que favoreça sua atuação como pessoas pensantes em relação } \\
\text { às questões energéticas vivenciadas na presente realidade em que vive com } \\
\text { capacidades e intenções de melhorar o mundo que o rodeia.” }\end{array}$ \\
\hline & Compreensão & São várias as concepções de cidadania que os autores apresentam. \\
\hline \multirow{2}{*}{\multicolumn{3}{|c|}{ Tabela 41 - Ficha de análise do trabalho Martinez et al. (2017) }} \\
\hline & & \\
\hline $\begin{array}{l}\text { Eixo de } \\
\text { Análise }\end{array}$ & & Informações extraídas e comentários \\
\hline \multirow{2}{*}{$\begin{array}{l}\text { Tema de } \\
\text { Referência }\end{array}$} & $\begin{array}{l}\text { Apresentado } \\
\text { pelos autores }\end{array}$ & Consumo de alimentos industrializados \\
\hline & Compreensão & $\begin{array}{c}\text { O tema alimentos industrializados talvez até esteja em alguma medida presente } \\
\text { no cotidiano, mas não com grande frequência, e sua relação com a cidadania } \\
\text { não é tão evidente. }\end{array}$ \\
\hline \multirow{2}{*}{$\begin{array}{l}\text { Relação do } \\
\text { professor com } \\
\quad \text { o } \\
\text { conhecimento } \\
\text { científico }\end{array}$} & $\begin{array}{l}\text { Apresentado } \\
\text { pelos autores }\end{array}$ & $\begin{array}{l}\text { "Para a escolha da temática a ser trabalhada foram aplicados questionários de } \\
\text { reconhecimento da realidade e do contexto vivenciado pelos alunos, o que } \\
\text { culminou na escolha dos alimentos industrializados.” Foi central para a } \\
\text { abordagem, também, a “experimentação problematizadora” }\end{array}$ \\
\hline & Compreensão & $\begin{array}{l}\text { Tanto pelo fato dos alunos terem sido consultados para a delimitação do tema } \\
\text { estudado, quanto pelo fato da “experimentação problematizadora” estar } \\
\text { bastante relacionada com uma situação cotidiana, há grande importância do } \\
\text { cotidiano. }\end{array}$ \\
\hline \multirow[t]{2}{*}{$\begin{array}{l}\text { Engajamento } \\
\text { dos alunos }\end{array}$} & $\begin{array}{l}\text { Apresentado } \\
\text { pelos autores }\end{array}$ & $\begin{array}{l}\text { “Na etapa de problematização, levantaram-se inicialmente alguns } \\
\text { conhecimentos prévios dos alunos por intermédio das duas questões } \\
\text { supracitadas na metodologia, e foi verificado que a princípio, os alunos não } \\
\text { enxergavam um problema, daí a importância da construção de uma } \\
\text { problematização em conjunto com os discentes, o que por sua vez implica em } \\
\text { maiores engajamentos destes nas atividades propostas.” }\end{array}$ \\
\hline & Compreensão & $\begin{array}{l}\text { Não há elementos que possibilitem afirmar qual o nível de envolvimento dos } \\
\text { alunos com as atividades realizadas. }\end{array}$ \\
\hline
\end{tabular}


Eixo de

Análise

Informações extraídas e comentários

Na Problematização Inicial, com uma aula, os pesquisadores procuraram "um problema para ser explorado durante as atividades realizadas", com uso de um questionário inicial, reconhecendo e valorizando as "concepções 'alternativas'” dos estudantes. Foram feitas duas perguntas, uma sobre o crescimento da população da Terra e outra sobre a possibilidade da ocorrência de prejuízos na busca por alimentar a população do planeta. Leitura do texto intitulado "A Indústria Alimentícia” e a realização de um debate guiado por cinco questões.

Atividades Apresentado Na Organização do Conhecimento, em uma aula, foi realizada uma experiência desenvolvidas pelos autores para a determinação de vitamina $\mathrm{C}$ em diferentes amostras de sucos, com o em sala auxílio da tintura de iodo. Na Aplicação do Conhecimento, com duas aulas, os alunos elaboraram uma dissertação sobre os aspectos que envolvem a produção de alimentos para suprir as necessidades da população, se valendo, para isso, de três pequenos textos, sobre o direito da população à alimentação, o uso de agrotóxicos em plantações e o desenvolvimento de alimentos transgênicos. Ao final, os alunos responderam a um questionário sobre suas concepções de "educação cidadã e das atividades trabalhadas."

\begin{tabular}{|c|c|c|}
\hline & Compreensão & Foram bastante variadas as atividades realizadas pelos estudantes \\
\hline \multirow[t]{2}{*}{$\begin{array}{l}\text { Participação } \\
\text { na sociedade } \\
\text { que os alunos } \\
\text { desenvolvem }\end{array}$} & $\begin{array}{l}\text { Apresentado } \\
\text { pelos autores }\end{array}$ & $\begin{array}{l}\text { “é de suma importância (...) levar em conta os conhecimentos prévios trazidos } \\
\text { pelos alunos para a sala de aula. Assim sendo, foram levadas aos alunos duas } \\
\text { questões que os instigassem a encontrar um problema a ser solucionado por } \\
\text { meio do conhecimento científico e da sua função como cidadão atuante em uma } \\
\text { sociedade” “Como resultado desse debate, chegou-se à conclusão de que a } \\
\text { indústria alimentícia veio ao encontro da mudança vivenciada pela sociedade, } \\
\text { como o êxodo rural e a necessidade de maior produção de alimentos, o que, no } \\
\text { entanto, implica em aspectos negativos como a perda de nutrientes essenciais } \\
\text { para a saúde humana devido aos processos industriais.” }\end{array}$ \\
\hline & Compreensão & $\begin{array}{c}\text { A cidadania é colocada em prática na forma de informação sobre as várias } \\
\text { dimensões que dizem respeito à alimentação e ao consumo de alimentos } \\
\text { processados. }\end{array}$ \\
\hline \multirow[t]{2}{*}{$\begin{array}{l}\text { Contexto da } \\
\text { prática } \\
\text { docente }\end{array}$} & $\begin{array}{l}\text { Apresentado } \\
\text { pelos autores }\end{array}$ & $\begin{array}{l}\text { “escola estadual Adahir Guimarães Fogaça, localizada na região norte da cidade } \\
\text { de São José do Rio Preto, com três turmas do } 3^{\circ} \text { ano do Ensino Médio, sendo } \\
\text { duas turmas matutinas e uma noturna, e uma turma noturna do 3o Ano da } \\
\text { Educação de Jovens e Adultos (EJA).” Foram realizadas } 4 \text { aulas no total. }\end{array}$ \\
\hline & Compreensão & Foram realizadas 4 aulas e o currículo como limitador não foi mencionado \\
\hline $\begin{array}{l}\text { Cidadania } \\
\text { apresentada } \\
\text { pelos autores }\end{array}$ & $\begin{array}{l}\text { Apresentado } \\
\text { pelos autores }\end{array}$ & $\begin{array}{l}\text { “o aluno apropriando-se do conhecimento científico estará dando um passo a } \\
\text { mais para se tornar um cidadão crítico na sociedade” “deve promover a } \\
\text { curiosidade e o espírito crítico nos alunos” “Ao abordar a prática de } \\
\text { experimentação problematizadora, uma linha tênue é traçada com o movimento } \\
\text { CTSA (...); afinal, a problematização surge do cotidiano do sujeito, } \\
\text { representando um obstáculo a ser superado pelo conhecimento científico” A } \\
\text { CTSA tem “como principal meta preparar os alunos para o exercício da } \\
\text { cidadania, em que, nesta perspectiva, a contextualização pode abordar desde } \\
\text { questões do cotidiano, de cunho mais individual, até questões mais globalizadas } \\
\text { (...), com a finalidade de valorizar a formação de indivíduos críticos e atuantes } \\
\text { na sociedade moderna.” ““contribuir de fato para a construção de uma } \\
\text { sociedade democrática, cujos membros sejam cidadãos conscientes e } \\
\text { comprometidos com a própria transformação da sociedade.”” "formação de } \\
\text { cidadãos críticos e atuantes na sociedade, capazes de tomar decisões } \\
\text { conscientes com base no conhecimento científico.” }\end{array}$ \\
\hline
\end{tabular}




\begin{tabular}{|c|c|c|}
\hline $\begin{array}{l}\text { Eixo de } \\
\text { Análise }\end{array}$ & & Informações extraídas e comentários \\
\hline & Compreensão & $\begin{array}{l}\text { A experimentação problematizadora, que é bastante semelhante a proposta por } \\
\text { Bachelard, propõe que a ciência se desenvolve com base em problemas e o } \\
\text { ensino de ciências deveria seguir passos semelhantes. Segundo os autores, a } \\
\text { CTS possui semelhanças com essa abordagem. }\end{array}$ \\
\hline
\end{tabular}

Fonte: Bondezan (2019).

Tabela 42 - Ficha de análise do trabalho Santos et al. (2017)

\begin{tabular}{|c|c|c|}
\hline $\begin{array}{l}\text { Eixo de } \\
\text { Análise }\end{array}$ & & Informações extraídas e comentários \\
\hline \multirow{2}{*}{$\begin{array}{l}\text { Tema de } \\
\text { Referência }\end{array}$} & $\begin{array}{l}\text { Apresentado } \\
\text { pelos autores }\end{array}$ & $\begin{array}{l}\text { "influência da concentração de soluções de íons metálicos } \mathrm{Cu}, \mathrm{Zn}, \mathrm{Al} \text { e Fe, no } \\
\text { crescimento de raízes de batata doce” }\end{array}$ \\
\hline & Compreensão & $\begin{array}{l}\text { O tema escolhido pelos autores é bastante específico e, embora não exatamente } \\
\text { curricular da disciplina de Química, é bastante difícil de se relacionar de } \\
\text { maneira geral com as outras disciplinas ou com a cidadania. }\end{array}$ \\
\hline \multirow{2}{*}{$\begin{array}{l}\text { Relação do } \\
\text { professor com } \\
\text { o } \\
\text { conhecimento } \\
\text { científico }\end{array}$} & $\begin{array}{l}\text { Apresentado } \\
\text { pelos autores }\end{array}$ & $\begin{array}{l}\text { “foram levantados alguns questionamentos sobre as potencialidades } \\
\text { pedagógicas (...) de que maneira uma prática pedagógica de química poderia } \\
\text { promover a articulação entre os saberes escolares, científicos e populares?” } \\
\text { "buscou-se introduzir brevemente a origem dos metais, usando o exemplo da } \\
\text { produção de ferro, tendo em vista a situação das empresas localizadas na região } \\
\text { metropolitana da cidade de Vitória, Espírito Santo. (...) Neste caso, foi possível } \\
\text { estabelecer conexões entre um dos conteúdos programáticos de química e a } \\
\text { realidade local.” }\end{array}$ \\
\hline & Compreensão & $\begin{array}{l}\text { A produção de batata doce faz parte do contexto do Espirito Santo, assim como } \\
\text { o consumo deste alimento, principalmente por praticantes de atividades físicas. } \\
\text { Além disso, este estado tem papel central na extração, transporte e exportação } \\
\text { de minério de ferro. Essas foram as motivações para o estudo do crescimento da } \\
\text { batata doce, e a influência de metais neste crescimento. }\end{array}$ \\
\hline \multirow[t]{2}{*}{$\begin{array}{l}\text { Engajamento } \\
\text { dos alunos }\end{array}$} & $\begin{array}{l}\text { Apresentado } \\
\text { pelos autores }\end{array}$ & $\begin{array}{l}\text { “Embora o professor tivesse clareza da parte experimental, para os estudantes } \\
\text { este procedimento consistiu num processo de descoberta. O debate teórico } \\
\text { sobre o preparo das soluções produziu uma série de dúvidas e hipóteses sobre a } \\
\text { influência de concentrações de íons metálicos no crescimento das raízes na } \\
\text { batata doce.” "O que poderia ser uma simples aula de soluções, nesse momento } \\
\text { passou a ter um sentido maior para aqueles estudantes da classe de química. } \\
\text { (com a ocorrência do desastre de Mariana)” }\end{array}$ \\
\hline & Compreensão & $\begin{array}{l}\text { Embora não seja possível afirmar com certeza o grau de motivação dos alunos, } \\
\text { eles parecem ter se envolvido bastante, principalmente no debate final que } \\
\text { ocorreu logo após o desastre de Mariana. }\end{array}$ \\
\hline $\begin{array}{l}\text { Atividades } \\
\text { desenvolvidas } \\
\text { em sala }\end{array}$ & $\begin{array}{l}\text { Apresentado } \\
\text { pelos autores }\end{array}$ & $\begin{array}{l}\text { Na problematização inicial, com quatro aulas, foi exibido o documentário sobre } \\
\text { a produção do aço a partir do minério de ferro, assim como um debate guiado } \\
\text { pela leitura de artigos sobre as reações de oxidorredução para a produção de } \\
\text { ferro e uma avaliação individual. Na organização do conhecimento, com } 6 \\
\text { aulas, foram ministradas aulas expositivas sobre conteúdos físico-químicos, } \\
\text { planejado o experimento do crescimento das raízes de batata doce quando em } \\
\text { contato com soluções de diferentes concentrações de diferentes metais e } \\
\text { realizado um relatório da primeira fase. Na aplicação do conhecimento, com } 6 \\
\text { aulas, os estudantes realizaram em grupos de } 5 \text { a } 7 \text { alunos o experimento } \\
\text { anteriormente planejado, assim como uma roda de conversa sobre o desastre de } \\
\text { Mariana, o associando com a experiência realizada e um relatório sobre o } \\
\text { experimento. }\end{array}$ \\
\hline
\end{tabular}




\begin{tabular}{|c|c|c|}
\hline $\begin{array}{l}\text { Eixo de } \\
\text { Análise }\end{array}$ & & Informações extraídas e comentários \\
\hline & Compreensão & $\begin{array}{l}\text { Houve a presença de um conjunto razoavelmente grande e diferente de } \\
\text { atividades realizadas. }\end{array}$ \\
\hline \multirow[t]{2}{*}{$\begin{array}{l}\text { Participação } \\
\text { na sociedade } \\
\text { que os alunos } \\
\text { desenvolvem }\end{array}$} & $\begin{array}{l}\text { Apresentado } \\
\text { pelos autores }\end{array}$ & $\begin{array}{l}\text { “Os debates (...) abordaram questões como as atividades de mineradoras, } \\
\text { especialmente a Vale que atua no Estado do Espírito Santo e Minas Gerais, a } \\
\text { produção e consumo de batata doce no Brasil e no Estado do Espírito Santo, a } \\
\text { contaminação de metais pesados no sistemas hídricos que podem comprometer } \\
\text { a qualidade da água consumida em casa, e o consumo de suplementos } \\
\text { alimentares na alimentação humana para melhorar a qualidade de vida.” “O } \\
\text { clímax dos debates foi alcançado (...) após o acidente da Samarco, com os } \\
\text { impactos ambientais na bacia hidrográfica do Rio Doce (...) que desaguou a } \\
\text { lama de rejeitos concentrados de metais pesados, causando danos ambientais ao } \\
\text { Rio Doce, abrangendo mais de } 200 \text { municípios” "houve relatos das quantidades } \\
\text { de peixes mortos em decorrência do acidente na bacia hidrográfica” }\end{array}$ \\
\hline & eensão & $\begin{array}{l}\text { A participação em sociedade realizada pelos alunos parece ter sido limitada, } \\
\text { pelo menos nos primeiros momentos da atividade, embora pareça ser mais } \\
\text { evidente nos momentos finais. As várias discussões realizadas diante do } \\
\text { desastre de Mariana se dedicaram a se dar conta do ocorrido, sem questionar as } \\
\text { ações da mineradora e sem procurar medidas para evitar tragédias semelhantes. }\end{array}$ \\
\hline \multirow[t]{2}{*}{$\begin{array}{l}\text { Contexto da } \\
\text { prática } \\
\text { docente }\end{array}$} & $\begin{array}{l}\text { Apresentado } \\
\text { pelos autores }\end{array}$ & $\begin{array}{l}\text { “O conteúdo programático de química previsto para o segundo ano do ensino } \\
\text { médio inclui soluções, equilíbrio químico, reações ácido-base e de oxirredução, } \\
\text { entre outros” A atividade foi desenvolvida em duas salas do segundo ano do } \\
\text { Ensino Médio de uma escola pública do Espírito Santo, envolvendo } 48 \text { alunos. } \\
\text { As atividades foram desenvolvidas em um longo intervalo de tempo (16 ou } 30 \\
\text { horas, conforme divergência no trabalho) }\end{array}$ \\
\hline & Compreensão & $\begin{array}{c}\text { Mesmo com divergência quanto a duração das atividades realizadas, certamente } \\
\text { o número de aulas foi grande. Além disso, a influência do currículo não foi } \\
\text { mencionada como cerceadora ou castradora. }\end{array}$ \\
\hline \multirow[t]{2}{*}{$\begin{array}{l}\text { Cidadania } \\
\text { apresentada } \\
\text { pelos autores }\end{array}$} & $\begin{array}{l}\text { Apresentado } \\
\text { pelos autores }\end{array}$ & $\begin{array}{l}\text { “sejam utilizados temas sociocientíficos para discutir conteúdos de ciências } \\
\text { articulados às questões morais, éticas, de valor, sobretudo, criar situações nas } \\
\text { quais as pessoas sejam obrigadas a se posicionarem” “No nosso caso, } \\
\text { utilizamos a temática sócio-científica da influência da concentração de íons Cu, } \\
\text { Zn, Al e Fe no crescimento de raízes de batata doce, a fim de produzir debates } \\
\text { além dos conteúdos de química normalmente trabalhados (...) englobando (...) } \\
\text { temáticas de saúde, problemas ambientais e tecnologia de alimentos” }\end{array}$ \\
\hline & Compreensão & $\begin{array}{l}\text { São poucas as informações mencionadas pelos autores sobre a compreensão de } \\
\text { cidadania que possuem. Esta compreensão se limita às questões morais, éticas e } \\
\text { a necessidade de se posicionar. }\end{array}$ \\
\hline
\end{tabular}

Fonte: Bondezan (2019).

Tabela 43 - Ficha de análise do trabalho Fadini e Leite (2017)

\begin{tabular}{ccc}
\hline $\begin{array}{c}\text { Eixo de } \\
\text { Análise }\end{array}$ & Informações extraídas e comentários \\
\hline & $\begin{array}{c}\text { Apresentado } \\
\text { pelos autores }\end{array}$ & Produção de alimentos \\
\cline { 2 - 3 } $\begin{array}{c}\text { Tema de } \\
\text { Referência }\end{array}$ & Compreensão & $\begin{array}{c}\text { O tema "produção de alimentos" é bastante amplo, não estando restrito a um } \\
\text { conceito de uma disciplina e nem mesmo a uma disciplina. Sua potencialidade } \\
\text { para a cidadania é um tanto indireta, com grande capacidade de ser localizada e } \\
\text { limitada. }\end{array}$ \\
\hline
\end{tabular}




\begin{tabular}{|c|c|c|}
\hline $\begin{array}{l}\text { Eixo de } \\
\text { Análise }\end{array}$ & & Informações extraídas e comentários \\
\hline \multirow[t]{2}{*}{$\begin{array}{l}\text { Relação do } \\
\text { professor com } \\
\quad \text { o } \\
\text { conhecimento } \\
\text { científico }\end{array}$} & $\begin{array}{l}\text { Apresentado } \\
\text { pelos autores }\end{array}$ & $\begin{array}{l}\text { “O projeto escolar chamado de ‘EducAlimentar’ (...) cujo objetivo maior foi } \\
\text { produzir debates sobre educação ambientar.” “o projeto escolar se iniciou com a } \\
\text { etapa de seleção dos estudantes, e buscando desafiar, motivar, questionar, } \\
\text { sensibilizar, mobilizar, levando-os a produzir conexões entre conteúdos } \\
\text { disciplinares e inter/transdisciplinares, manifestando as suas lutas, realizações e } \\
\text { contradições.” A seleção dos alunos ocorreu por meio de uma prova com tema } \\
\text { “educação alimentar”. }\end{array}$ \\
\hline & Compreensão & $\begin{array}{l}\text { O conhecimento científico parece ter como ponto de partida e fio condutor a } \\
\text { educação alimentar, algo que está muito mais próximo do cotidiano dos } \\
\text { estudantes do que do currículo ou da cidadania. }\end{array}$ \\
\hline \multirow{2}{*}{$\begin{array}{l}\text { Engajamento } \\
\text { dos alunos }\end{array}$} & $\begin{array}{l}\text { Apresentado } \\
\text { pelos autores }\end{array}$ & $\begin{array}{l}\text { “Desde a divulgação na escola até o momento da realização da redação, } \\
\text { observei grande envolvimento e entusiasmo dos estudantes em participar do } \\
\text { projeto. Todos realizaram as redações com seriedade e compromisso” }\end{array}$ \\
\hline & Compreensão & $\begin{array}{l}\text { A partir deste relato do professor, é possível afirmar que os alunos foram } \\
\text { profundamente motivados pelas atividades. }\end{array}$ \\
\hline \multirow[t]{2}{*}{$\begin{array}{l}\text { Atividades } \\
\text { desenvolvidas } \\
\text { em sala }\end{array}$} & $\begin{array}{l}\text { Apresentado } \\
\text { pelos autores }\end{array}$ & $\begin{array}{l}\text { Na Prática Social Inicial os estudantes foram selecionados para participar do } \\
\text { projeto por meio de uma prova com o tema “Educação Alimentar”. Na } \\
\text { Problematização os alunos estudaram a Educação Alimentar participando de } \\
\text { atividades expositivas que destacaram a interdisciplinaridade dos assuntos. Na } \\
\text { Instrumentalização os estudantes planejaram a visita a espaços de produção } \\
\text { alimentar e a construção de monografias. Foram escolhidos os locais de } \\
\text { visitação e a construção de roteiros para a coleta de informações. Na Cartase os } \\
\text { estudantes visitaram os locais de produção alimentícia. } \\
\text { Na Prática Social Final os estudantes participaram de rodas de conversa com o } \\
\text { intuito de “sintetizar as etapas realizadas ao longo do semestre, com a } \\
\text { construção social de uma pequena monografia desenvolvida na perspectiva da } \\
\text { aprendizagem colaborativa. Cada grupo apresentou um pequeno resumo das } \\
\text { etapas vivenciadas durante o desenvolvimento do projeto, orientadas por } \\
\text { algumas perguntas do professor.” }\end{array}$ \\
\hline & Compreensão & Foram bastante diversificadas as atividades realizadas \\
\hline \multirow[t]{2}{*}{$\begin{array}{l}\text { Participação } \\
\text { na sociedade } \\
\text { que os alunos } \\
\text { desenvolvem }\end{array}$} & $\begin{array}{l}\text { Apresentado } \\
\text { pelos autores }\end{array}$ & $\begin{array}{c}\text { “Depois que a gente foi na vigilância sanitária eu comecei a ver as coisas meio } \\
\text { que diferentes, pois antes eu não observava, tipo, a temperatura que tava o } \\
\text { armazenamento dos produtos que colocavam lá, comprava o queijo com aquela } \\
\text { aguinha de cor diferente e não sabia o que que era aquilo e hoje não, eu já } \\
\text { observo e já sei o que é o certo e o que é o errado, e tipo, do jeito que eles estão } \\
\text { armazenando se está certo, ou alguma coisa que eles estão deixando ali que vai } \\
\text { prejudicar a gente” }\end{array}$ \\
\hline & Compreensão & $\begin{array}{l}\text { As atividades realizadas pelos alunos acabaram por ficar um tanto distantes da } \\
\text { cidadania. A prática social final consistiu em uma roda de conversa em que os } \\
\text { alunos avaliaram o que aprenderam, sendo que os conhecimentos adquiridos } \\
\text { são restritos à produção, consumo e conservação de alimentos. }\end{array}$ \\
\hline \multirow[t]{2}{*}{$\begin{array}{l}\text { Contexto da } \\
\text { prática } \\
\text { docente }\end{array}$} & $\begin{array}{l}\text { Apresentado } \\
\text { pelos autores }\end{array}$ & $\begin{array}{l}\text { Participaram desta atividade } 16 \text { estudantes com idades entre } 14 \text { e } 18 \text { anos, que } \\
\text { frequentaram as atividades no contraturno do Ensino Médio Regular. A prática } \\
\text { que seguiu as cinco etapas da Pedagogia Histórico-Crítica ocorreu em um longo } \\
\text { espaço de tempo. }\end{array}$ \\
\hline & Compreensão & Nada a comentar \\
\hline
\end{tabular}




\begin{tabular}{|c|c|c|}
\hline $\begin{array}{l}\text { Eixo de } \\
\text { Análise }\end{array}$ & & Informações extraídas e comentários \\
\hline \multirow[t]{2}{*}{$\begin{array}{c}\text { Cidadania } \\
\text { apresentada } \\
\text { pelos autores }\end{array}$} & $\begin{array}{l}\text { Apresentado } \\
\text { pelos autores }\end{array}$ & $\begin{array}{l}\text { “Morin (2011) ressalta que, para garantir uma educação para o futuro, com } \\
\text { vistas a uma democracia e uma cidadania terrestre, exige um esforço } \\
\text { interdisciplinar e transdisciplinar para que isso seja alcançado.” "De acordo } \\
\text { com Sadler (2011), temas sociocientíficos são questões ou temas da sociedade } \\
\text { que apresentam características socioeconômicas, sócio-históricas, } \\
\text { sociopolíticas, socioculturais, éticas e socioambientais relativas à construção } \\
\text { social da ciência e tecnologia, visando à formação de cidadãos ativos e } \\
\text { emancipados.” “envolvendo debates sobre questões cotidianas, como o } \\
\text { tratamento de efluentes, tratamento de água, uso de agrotóxico na produção de } \\
\text { alimentos, alimentos transgênicos, experiências científicas com uso de cobaias } \\
\text { de animais, o controle de doenças infectocontagiosas” }\end{array}$ \\
\hline & Compreensão & Nada a comentar \\
\hline
\end{tabular}

Fonte: Bondezan (2019). 